\title{
Sandra Rodrigues de Oliveira
}

\author{
É possível dizer adeus? Repercussões \\ de múltiplas perdas e desaparecimento de \\ pessoas em contextos de desastre
}

Tese de Doutorado

Tese apresentada como requisito parcial para obtenção do grau de Doutor pelo Programa de Pós-Graduação em Psicologia (Psicologia Clínica) da PUC-Rio.

Orientadora: Prof ${ }^{\mathrm{a}}$ Terezinha Féres-Carneiro 
Sandra Rodrigues de Oliveira É possível dizer adeus? Repercussões de múltiplas perdas e desaparecimento de pessoas em contextos de desastre

Tese apresentada como requisito parcial para obtenção do grau de Doutor pelo Programa de PósGraduação em Psicologia (Psicologia Clínica) da PUCRio. Aprovada pela Comissão Examinadora abaixo assinada.

Profa. Terezinha Féres-Carneiro Orientadora Departamento de Psicologia - PUC-Rio

Profa. Andrea Seixas Magalhães Departamento de Psicologia - PUC-Rio

Profa. Solange Jobim Souza Departamento de Psicologia - PUC-Rio

Profa. Heliana de Barros Conde Rodrigues UERJ

Profa. Maria Helena Pereira Franco PUC/SP

Profa. Denise Berruezo Portinari Coordenadora Setorial de Pós-Graduação

e Pesquisa do Centro de Teologia e Ciências Humanas - PUC-Rio

Rio de Janeiro, 14 de março de 2014. 
Todos os direitos reservados. É proibida a reprodução total ou parcial do trabalho sem autorização da Universidade, da autora e da orientadora

\section{Sandra Rodrigues de Oliveira}

Graduou-se em Psicologia pela Pontifícia Universidade Católica de São Paulo em 2003. Mestre em Psicologia Clínica pela Pontifícia Universidade Católica do Rio de Janeiro em 2008. Possui experiência na área Hospitalar e, atualmente, atua na área de pesquisa e docência.

Ficha Catalográfica

Oliveira, Sandra Rodrigues de

É possível dizer adeus? Repercussões de múltiplas perdas e o desaparecimento de pessoas em contextos de desastre / Sandra Rodrigues de Oliveira; orientadora: Terezinha Féres-Carneiro. 2014.

215 f. : il. (color.) ; $30 \mathrm{~cm}$

Tese (doutorado) - Pontifícia Universidade Católica do Rio de Janeiro, Departamento de Psicologia, 2014.

Inclui bibliografia 
Dedico este trabalho à minha família - minha mãe,

Rosa, que me ensinou o valor de lutar pelos meus sonhos, e a meus irmãos, Ricardo e Eduardo, que apesar de nossa distância física, sempre estiveram ao meu lado. Obrigada por fazerem parte dos momentos mais importantes da minha vida. Vocês são meus exemplos e meu orgulho, são a força que preciso para seguir em frente na busca por meus objetivos. 


\section{Agradecimentos}

À Terezinha Féres-Carneiro, minha orientadora e parceira neste longo, mas gratificante percurso de pesquisa. Obrigada por sempre acreditar em mim e me ajudar a superar tantos momentos difíceis durante todos esses anos. Seus apontamentos sempre tão pertinentes, seu olhar crítico e ao mesmo tempo acolhedor me guiaram nessa jornada. Obrigada por tudo!

À professora Maria Helena Pereira Franco, minha professora, colega de profissão, coordenadora e, principalmente, uma grande amiga, a quem muito admiro e me espelho profissionalmente. Por todos os anos de convivência, aprendizado, cuidado e parceria, não há como expressar minha gratidão. Que nossos caminhos continuem se encontrando sempre!

À professora Heliana Conde, da UERJ, por sua disponibilidade e carisma, além de sempre me ensinar algo novo e valioso a cada vez que nos encontramos. Sua presença e perspicácia me acompanham desde o Mestrado, e me levam sempre a questionar, querer e poder mais. A você, meu carinho e meu muito obrigada!

À PUC-Rio pelos auxílios concedidos, sem os quais o trabalho não poderia ter sido realizado. Às professoras Solange Jobim e Andréa Seixas e todos os docentes do Programa, por seus ensinamentos preciosos e pela dedicação e comprometimento com o corpo discente. Não posso deixar de agradecer também a Marcelina e a Vera, por toda paciência e respeito com que sempre tratam a todos.

A meu companheiro Alexandre, por seu carinho, dedicação, paciência e compreensão, pois ao estar ao meu lado deixou a caminhada mais leve. Seu apoio me fez sentir segura e confiante para vencer os desafios e espero contigo poder dividir as alegrias que ainda estão por vir. 
Aos amigos de profissão e da vida toda, Adriana, Virgínia, Rafaela, Maíra, Maria, Renata, Leonardo, Cibele e Julia. Só posso dizer que os anos passam e as amizades verdadeiras permanecem. Obrigada por, desde a graduação, fazerem dos meus questionamentos a força motriz para que eu seguisse buscando meus objetivos.

Às amigas Vanessa Maia, Cristina Marques, Suzana Rodrigues, Priscila Marx e Ana Maria Camelo, que comigo trilharam o caminho do Mestrado e sempre me incentivaram a continuar investindo em meus sonhos. Foi junto delas que conheci e me reconheci na PUC-Rio e, desde então, este sentimento de estar "em casa" só aumentou. Também agradeço muito aos amigos Ana Abreu, Emmy, Sérgio, Vanessa, Rebecca, Raphael, Ana Valéria, Débora, Flávia, e todos os companheiros que partilharam comigo dessa jornada como doutorandos. A vocês, dedico também este trabalho.

Às amigas Luisa, Janaína e Fábia, pessoas iluminadas que sempre acreditaram em mim e torcem, cada uma de um cantinho do Brasil, pelo meu sucesso. Saibam que a amizade e o carinho de vocês são fundamentais, e mesmo que a distância física nos mantenha separadas por longos períodos, o sentimento que nos une é mais forte e mais bonito.

Aos companheiros do grupo Ipê (Intervenções Psicológicas em Emergências) pelo incentivo e por me manterem sempre motivada e atualizada sobre os temas relacionados ao luto. O trabalho que realizamos juntos é recompensador, mas a amizade que construímos é ainda mais gratificante.

Não poderia deixar de agradecer as minhas queridas amigas do Exército: Marina, Renata, Alessandra, Ana Gomes, Patricia, Viviane, Vania, Melissa, Jonia, Thais, Silvia, Bruna, Mayara, Joanita, Érica, Luana, Lívia, Daniele, Milena, Roberta, Taissa, Adriana, Débora, Priscila, Tatiana, Chagas, Luiz Fernando, Nóbrega, Murilo, Fatima, Eliane, Ângela, Marina e Soraya, além de todos os que dividem comigo essa vida verde oliva. Nossa batalha é diária e essa tese é prova de que são as amizades que nos movem, pois com vocês dividi minhas angústias e dúvidas, sempre recebendo em troca acolhimento, compreensão e incentivo. Amo vocês, xuxus! 


\section{Resumo}

Oliveira, Sandra Rodrigues; Féres-Carneiro, Terezinha. É possível dizer adeus? Repercussões de múltiplas perdas e o desaparecimento de pessoas em contextos de desastre. Rio de Janeiro, 2014, 215p. Tese de Doutorado Departamento de Psicologia, Pontifícia Universidade Católica do Rio de Janeiro.

Perdas em desastres tendem a ocorrer simultânea ou consecutivamente, o que pode representar um fator de risco para o enfrentamento dos diversos lutos vivenciados. Diante do crescente e preocupante número de emergências ao redor do mundo, faz-se premente a reflexão-ação acerca destes fenômenos, os quais atingem milhares de pessoas todos os anos. Este estudo teve como objetivo investigar a vivência de ser sobrevivente (direto ou indireto) do Megadesastre ocorrido na Região Serrana do Rio de Janeiro em janeiro de 2011 e quais as reações diante das incontáveis perdas individuais e coletivas, especialmente quando, por ocasião da catástrofe, muitos perderam familiares que permaneceram como desaparecidos e nunca tiveram seus corpos localizados. A pesquisa também investigou o impacto das perdas simbólicas e de objetos de valor sentimental que, somadas as perdas humanas e materiais, trazem grande sofrimento aos enlutados. Foram participantes desta pesquisa 20 (vinte) moradores das cidades de Petrópolis, Teresópolis e Nova Friburgo, entrevistados cerca de um ano e meio após a tragédia na região. Os dados foram discutidos a partir do referencial da Análise de Conteúdo e do conceito de testemunho, que trata da importância da narrativa no processo de elaboração de traumas. Como resultados, podemos destacar um alto grau de desorganização e medo nos primeiros momentos após o desastre, associados a sentimentos de angústia, impotência, desamparo e incerteza. Queixas somáticas e hipervigilância foram frequentes, deflagrando o alto nível de estresse dos sobreviventes (estivessem estes presentes ou não nos locais atingidos). As perdas humanas foram referidas como as mais dolorosas e 
incompreensíveis, principalmente nos casos de desaparecimento, pois ao mesmo tempo em que os enlutados mantinham acesa a esperança no reencontro com o ente querido, vivenciaram também ansiedade e indignação diante das inúmeras incertezas próprias a este tipo de luto tão ambíguo. A impotência foi o sentimento mais citado diante da ausência prolongada dos familiares e a impossibilidade de concretização da morte impediu que muitos enlutados dessem prosseguimento ao processo de elaboração - fato este associado também a forma como muitas famílias foram tratadas pelos profissionais das equipes médica e de resgate atuantes na ocasião e à realização de rituais coletivos sentidos como um desrespeito ao desejo das famílias. Perdas de imóveis, emprego e locais de referência (como escola, igreja, entre outros) intensificaram os sentimentos de tristeza e desalento, além de tornarem a rede de apoio ainda mais escassa, tendo em vista que o desastre se abateu sobre toda a comunidade, que sentiu-se desamparada, desprotegida e desesperançada. Ainda em relação ao suporte social após o desastre, os participantes também fizeram referência a sensação de abandono e descaso com relação aos governantes que não demonstraram interesse nem comprometimento com a reconstrução das comunidades destruídas pela tragédia, além das inúmeras denúncias de desvio de doações e verbas destinadas à população. Porém, foi possível identificar também sentimentos positivos em relação ao grupo, além de atos de heroísmo, solidariedade, compaixão e motivação para a ação (ação esta voltada para a reconstrução da vida em família e em sociedade). Concluímos que desastres são eventos traumáticos, intensos e disruptivos, que trazem prejuízos humanos, sociais e financeiros à sociedade e desestruturam famílias e comunidades de forma brusca e avassaladora, exigindo dos sobreviventes um grande esforço para superar as múltiplas perdas vividas; no entanto, mesmo diante de todo caos e devastação, surgem entre os escombros a esperança e a capacidade de renascimento de pessoas e grupos resilientes.

\section{Palavras-chave}

Desaparecimento; perdas múltiplas; luto ambíguo. 


\section{Abstract}

Oliveira, Sandra Rodrigues; Féres-Carneiro, Terezinha (Advisor). Is it possible to say goodbye? Repercussions of multiple losses and the disappearance of people in contexts of disaster. Rio de Janeiro, 2014, 215p. Thesis Departamento de Psicologia, Pontifícia Universidade Católica do Rio de Janeiro.

Losses in disasters tend to occur simultaneously or consecutively, which may represent a risk factor to tackle the many bereavements experienced. Concerning the increasing and worrying number of emergencies around the world, the reflection-action regarding this phenomena, which happen to thousands of people every year, is urgent. This study aimed at investigating the experience of being a (direct or indirect) survivor in the mega disaster which occurred in the sierra region of Rio de Janeiro in January 2011 and the reactions to the countless individual and collective losses, especially because, when the catastrophe took place, many lost relatives who remained missing and never had their bodies found. The research also investigated the impact of both symbolic losses and losses of objects of emotional value which, together with the human and material losses, bring great suffering to the bereaved. Twenty (20) inhabitants of the cities of Petrópolis, Teresópolis and Nova Friburgo participated in the research, being interviewed about a year and a half after the tragedy in the region. The data were discussed based on the Content Analysis referential and the testimony concept, which deals with the importance of the narrative in the process of elaboration of traumas. As results, we can highlight a high level of disorganization and fear in the first moments after the disasters, associated with feelings of anguish, impotence, helplessness and uncertainty. Somatic complaints and hypervigilance were frequent, resulting in the survivor's high level of stress (even though they may not have been present in the affected regions). Human losses were considered the most painful and incomprehensible, mainly in the cases of the missing people, 
since meanwhile the bereaved were hopeful to see their beloved one again, they also experienced anxiety and outrage owing to the innumerous uncertainties which are part of such an ambiguous type of bereavement. Impotence was the most mentioned feeling on account of the relative's prolonged absence and the impossibility to materialize death prevented many bereaved people from giving continuity to the process of elaboration - a fact also associated with the way many families were treated by professionals who belonged to the medical and rescue teams who worked in the disaster area and the performance of collective rituals which were seen as disrespectful to the families' wish. Buildings, jobs, and reference places (such as schools and churches, among others) were lost, which intensified the feelings of sadness and dismay, besides making the support network even more scarce, as the disaster happened to the whole community, who felt helpless, unprotected and hopeless. Still regarding social support after the disaster, the participants also made reference to a feeling of abandonment and neglect by the governors who demonstrated neither interest nor commitment to rebuilding the communities affected by the tragedy, besides the numberless reports of misuse of donations and funds destined to the population. However, it was possible to identify positive feelings in relation to the group as well, in addition to acts of heroism, sympathy, compassion and motivation to act (act in order to rebuild family and society life). We concluded that disasters are traumatic, intense and disruptive events, which bring human, social and financial damages to society and destabilize families and communities in an abrupt and overwhelming way, demanding the survivors to make a big effort so that they can overcome the multiple losses experienced; however, even in the midst of chaos and devastation, resilient people and groups' hope and rebirth capacity appear among the debris.

\section{Keywords}

Disappearance; multiple losses; ambiguous loss. 


\section{Sumário}

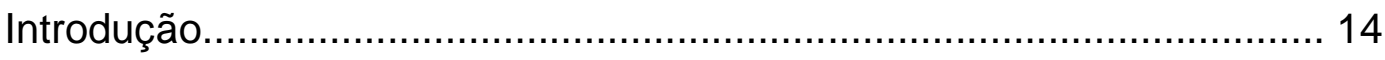

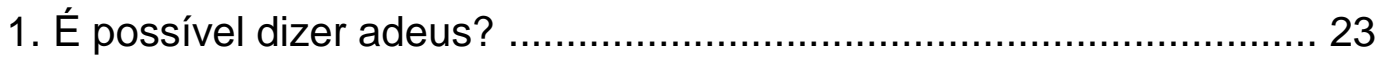

1.1. Teoria do Apego - por uma vida com os outros ............................ 25

1.2. Luto: o preço que pagamos pelo afeto que trocamos....................... 28

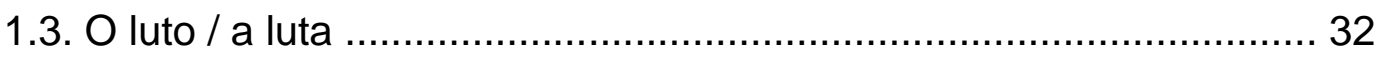

1.4. Luto na família e na comunidade: unidos venceremos? .................. 39

1.5. Meu eu sem você: o luto complicado ............................................ 44

2. Perdas múltiplas e desastres: inevitável combinação ......................... 52

2.1. Um olhar sobre a questão dos desastres ....................................... 53

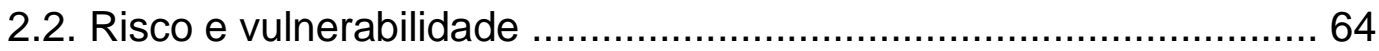

2.3. As chuvas da Região Serrana: desta vez, em janeiro de $2011 \ldots \ldots . . .73$

2.4. Desaparecimentos: a interminável e inominável ausência ............... 80

3. "Sem eira, nem beira, nem nada" 83

3.1. Entre mortos e feridos, há também os desaparecidos ................... 92

3.2. "Não tinha teto, não tinha nada" ........................................... 100

3.3. Memória e trauma: do testemunho à narrativa, da narrativa à reconstrução …….............................................................. 105

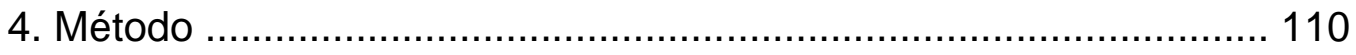

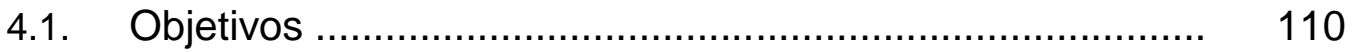

4.2. Participantes ......................................................... 110

4.3. Apresentação dos casos ....................................................... 113

4.4. Procedimentos de Análise ................................................ 124 
5. Análise e discussão dos resultados ….................................. $\quad .126$

5.1. Primeiras reações as perdas .......................................... 126

5.2. Desaparecimento de membro da família ...................................141

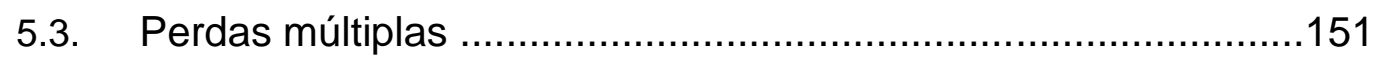

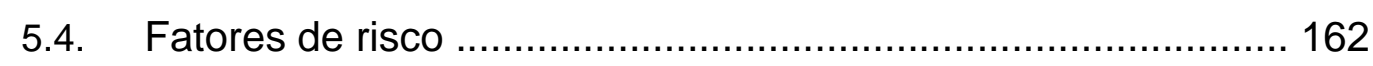

5.5. Memória individual e memória coletiva .................................. 176

5.6. Rede de apoio e envolvimento da comunidade no processo de reconstrução individual e coletiva .............................................. 180

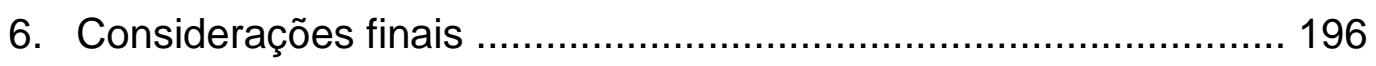

Referências bibliográficas ........................................................ 203

\begin{abstract}
ANEXOS
Anexo I - Roteiro preliminar de entrevista .......................................211

Anexo II - Ficha de Identificação dos participantes e Termo de

Consentimento Livre e Esclarecido .............................................. 212

Anexo III - Tabela de participantes ............................................... 214
\end{abstract}




\section{DESATRE}

Tão nobre tuas ruas,

Tão alegre teu povo,

Belas árvores,

Belos rios,

Mas o morro,

Com as chuvas

Cedeu e não fez curvas,

Desceu sua própria ladeira,

Carregando consigo,

Além de sonhos,

Milhares de abrigo

Do povo

De novo

Do morro...

Sem rua,

Menos gente,

Árvores sem cor,

Rio de lama,

Enterro coletivo.

Choro, tristeza e dor.

Todos sem abrigo,

Sem ter para onde ir,

Voltarão a viver com o perigo.

Outros, em sua crença,

Perguntam a Deus se é um castigo.

Muitos sem mãe

Outros sem pai ou filho.

Família do abismo.

Pobre Cristo

de braços abertos

Não pode fazer nada

Pois, lá de cima, olha

Os que ainda dormem nas calçadas

da chuva passada.

E, agora, o que fazer?

Desligar a tv?

(Joerlândio Cordeiro) 


\section{INTRODUÇÃO}

Não é no silêncio que os homens se fazem, mas na palavra, no trabalho, na ação-reflexão.

(FREIRE, 1987)

Temas como luto e família sempre me instigaram e, felizmente, permearam os diferentes caminhos profissionais que trilhei nestes 10 anos desde minha formação como psicóloga. Trabalhar com grupos familiares é algo motivante mas, ao mesmo tempo, desafiador, especialmente quando seus membros são confrontados com a dor da perda de algo ou alguém importante, seja esta temporária ou definitiva.

Ao ingressar no curso de Doutorado em Psicologia Clínica, tinha como objetivo dar continuidade ao trabalho já iniciado durante o Mestrado, no qual estudei o impacto do desaparecimento misterioso de uma criança de seu núcleo familiar. Durante a dissertação, trabalhei com mães que não tinham nenhuma informação sobre o paradeiro de seus filhos, mas que nunca desistiram de buscálos. Sentimentos como culpa, vergonha, angústia, medo, fé, esperança de reencontro versus impotência frente à total falta de informações sobre a localização das crianças ficaram evidentes, deflagrando as muitas ambivalências comuns a este tipo de perda.

Dentre as constatações do Mestrado, destaco também a questão da ausência de rituais nos casos de desaparecimento, já que não se sabe se o familiar ausente está vivo ou morto; no relato das entrevistadas, percebemos claramente a dificuldade de seguir em frente diante de tantas incertezas e a ausência de espaços para ventilação de seus medos e angústias, além do não reconhecimento e falta de apoio da rede social diante do prolongamento do luto que se mantém indefinido enquanto os filhos permanecem desaparecidos. A importância da localização dos filhos e da concretização da morte, se este fosse o caso, foi uma constante na fala das participantes, e confirma o papel fundamental destes ritos que dão significado, permitem a expressão de apoio dos pares e validam os sentimentos suscitados pela perda, o que, consequentemente, auxilia no processo de elaboração da mesma. 
Como pesquisadora - mas também cidadã inquietada por este assunto tão delicado - continuei me aprofundando no tema dos desaparecimentos, e mantiveme constantemente informada sobre quaisquer acontecimentos correlatos à pesquisa; foi então que, em janeiro de 2011, já no início do segundo ano do programa, pude acompanhar pela mídia as notícias sobre as chuvas que devastaram a Região Serrana do Rio de Janeiro, mais especificamente as cidades de Petrópolis, Teresópolis, Nova Friburgo, São José do Vale do Rio Preto e Sumidouro. As chuvas duraram em torno de três semanas, tendo seu auge nos dias 11, 12 e 13 de janeiro daquele ano.

Dentre as estatísticas do desastre foram contabilizados, ao final do mês de março de 2011, cerca de 900 mortos, 35.000 desalojados e desabrigados e aproximadamente 400 desaparecidos (PORTAL G1, 2011). Além das dolorosas e imensuráveis perdas humanas, as cidades tiveram inúmeros prejuízos materiais; impactos foram registrados na indústria, agricultura, pecuária, comércio, turismo e demais prestadores de serviços. O caos e a devastação nestas localidades tomaram conta dos noticiários e, apesar de não ser natural do estado, mas já moradora da cidade do Rio de Janeiro há quase 10 anos, fui também atingida por essa tragédia que deixou milhares de cariocas - de berço e de coração, como eu - com sentimentos de insegurança, impotência e profunda tristeza pelas incontáveis perdas vividas pelos sobreviventes diretos e indiretos desta catástrofe.

A partir destes acontecimentos, senti-me completamente envolvida e motivada para investir em um novo projeto de pesquisa, que ainda assim me ligava ao meu tema inicial: como se dá o processo de luto das pessoas que possuem familiares desaparecidos em decorrência das chuvas que atingiram a Região Serrana, ao mesmo tempo em que estas são, também, vítimas/sobreviventes do mesmo evento? Como lidar com perdas materiais, de moradia, de bens pessoais e de valor sentimental (como fotos, documentos e roupas) concomitantemente às perdas humanas? É possível fornecer e receber apoio dos pares, tão importante nestes casos, quando toda comunidade da qual se faz parte foi afetada pelo mesmo fenômeno?

Perdas fazem parte do processo de desenvolvimento natural de todos os seres humanos. O luto se faz presente não só nos casos de morte, mas também por ocasião de separações e rompimentos (seja de relacionamentos amorosos ou 
amizades), bem como em momentos de perdas materiais, de status ou da própria identidade. Quando falamos em desastres, muitas destas perdas ocorrem ao mesmo tempo, elevando os riscos para a saúde física e mental dos atingidos.

Ao nos debruçarmos sobre o tema, percebemos que a questão dos desastres data de milhares de anos, o que torna ainda mais preocupante a escassez de estratégias e recursos destinados, em alguns países, à assistência as pessoas atingidas por este tipo de evento. O despreparo e a baixa capacitação técnicoprofissional podem agravar ainda mais um quadro que, por si só, já é altamente preocupante e o prognóstico diante de tantas perdas dependerá, consideravelmente, das medidas adotadas em caso de catástrofe.

Se fizermos um pequeno recorte histórico sobre a questão dos desastres, poderemos notar a magnitude deste tipo de ocorrência em diferentes épocas, culturas e comunidades: entre os registros das chamadas catástrofes naturais, encontramos eventos desde a erupção do Monte Vesúvio já em 79 d.C até a explosão vulcânica no Lago Taupo, na Nova Zelândia, em 180 d.C (no qual foram expelidos $100 \mathrm{~km}^{3}$ de lava e rochas, equivalente a 148 mil vezes o maior navio petroleiro do mundo, o que acarretou na morte de mais de 92.000 pessoas). Estes foram os primeiros grandes desastres registrados no mundo (SPIGNESI, 2005).

Outro registro importante refere-se à Peste Negra, epidemia que atingiu diversos países na Ásia Central e Europa entre os anos de 1330 e 1351, e matou aproximadamente 175.000 .000 pessoas, sendo o maior número de falecimentos decorrentes de um mesmo agente causador da História. Já no século XX, a Gripe Espanhola, datada de 1915 a 1919, levou a triste marca de 40.000 .000 de mortes na Ásia Central, Europa, Américas e norte da África.

Quanto aos fenômenos geodinâmicos, podemos citar o "Tornado dos Três Estados", como ficou conhecido o desastre em Missouri - EUA em 1925, quando um ciclone durou mais de três horas e percorreu 353 quilômetros, vitimando 747 pessoas. Anos depois, em 1970, o grande Ciclone de Bhola devastou Bangladesh, e estimativas apontam entre 300.000 a 500.000 pessoas falecidas e desaparecidas. Entre os fenômenos tectônicos, podemos citar o terremoto que devastou Senshi, na China, em 1556, deixando mais de 830.000 mortos; e o terremoto de Valdívia, no Chile em maio de 1960 que, de tamanha violência, provocou tsunamis que chegaram até ao Japão (o nível da água subiu cerca de 4 metros e 130.000 casas 
foram destruídas), com total de mortos estimado em, pelo menos, 6.000 pessoas (SPIGNESI, 2005). Mais recentemente, no ano de 2010, um terremoto no Haiti matou cerca de 200.000 pessoas e seus destroços ainda podem ser encontrados por toda capital do país, Porto Príncipe.

Já entre os fenômenos pluviométricos, podemos referir as inundações na China em 1887, quando o rio Hwang He transbordou, matando mais de 900.000 pessoas. O país foi novamente desolado em 1931, quando o rio Yang Tsé também transbordou, atingindo a triste marca de 4.000.000 de mortes. Em 2004, lembramos com pesar o tsunami no Oceano Índico, que teve início com um terremoto submarino de magnitude 9.3, dizimando cerca de 230.000 pessoas (SPIGNESI, 2005). Nesta categoria, encontram-se também as chuvas ocorridas na Região Serrana do Rio de Janeiro que atingiram a triste marca de maior desastre natural do estado (PORTAL G1, 2011).

Não podemos deixar de citar também fenômenos como o Katrina, furacão ocorrido no Sul dos EUA no ano de 2005, quando ventos de até $280 \mathrm{~km} / \mathrm{h}$ destruíram Nova Orleans, deixando milhares de famílias desoladas; e em 2012, o furacão Sandy, que atingiu diversos países do Caribe, com maior impacto na Jamaica, Bahamas, República Dominicana e Haiti, além de atingir cidades como Nova Iorque e Nova Jersey (o número de mortos e desaparecidos chegou a 74 somente no Haiti, país mais atingido pela catástrofe). Furacões como o Katrina e Sandy alertam, principalmente, para a importância de boas estratégias de contenção de danos e deflagram como a quantidade de recursos disponíveis nas áreas de segurança, saúde e pronto-atendimento pré e pós-desastre podem ser determinantes para a reestruturação do país (ONU, 2012a).

Além dos chamados eventos climáticos, nossa História está repleta de catástrofes de origem não natural - as chamadas catástrofes de origem humana ou mista - dentre as quais podemos destacar o desastre em Hiroshima ocorrido em 1945; e Chernobyl, na Ucrânia, em abril de 1986, considerado o maior desastre nuclear já registrado, quando um dos reatores da central explodiu, causando um intenso incêndio seguido de várias explosões, produzindo uma nuvem radioativa que atingiu a União Soviética, Europa Ocidental e parte do Reino Unido. 
Impossível esquecer ainda os ataques terroristas aos EUA e a queda das Torres Gêmeas, fato ocorrido em setembro de 2001, quando cerca de 3.000 pessoas padeceram dentro e fora dos edifícios e tantos outros nos demais atentados ocorridos naquela triste manhã de terça-feira (SPIGNESI, 2005). No Brasil, podemos citar como exemplos os desastres aéreos envolvendo aeronaves das empresas GOL Linhas Aéreas e TAM Linhas Aéreas (em 2006 e 2007, respectivamente), além do triste episódio do incêndio na Boate Kiss, em Santa Maria-RS em janeiro de 2013 que levou a morte de 242 pessoas (UOL, 2013).

Em 2013, ainda no Brasil, pudemos acompanhar em todo o país uma série de manifestações públicas populares contra ações governamentais, abuso de poder e uso indevido de dinheiro público, que foram duramente reprimidas pelas polícias locais, o que confirma a prerrogativa atual de diversos estudiosos sobre o tema: além dos eventos da natureza e catástrofes relacionadas ao desenvolvimento tecnológico global, os conflitos políticos, econômicos, religiosos e culturais também podem ser considerados desastres (estes últimos denominados como eventos de violência massiva (NORRIS, 2002)).

Infelizmente, mesmo tendo em mãos todos estes dados brutos sobre o número de pessoas vitimadas em decorrência de desastres, é impossível mensurar a quantidade de pessoas enlutadas nestas tragédias. Além dos milhares de sobreviventes - os quais não só sofrem a perda de pessoas próximas, mas também podem ter sido feridos durante os eventos - temos que pensar no devastador impacto das perdas concomitantes, perdas estas que não podemos estimar apenas pelo valor financeiro envolvido, mas que merecem um olhar do ponto de vista da constituição do sujeito e pela forma como as identidades são abaladas diante das inúmeras rupturas vividas neste período.

$\mathrm{Na}$ maioria dos casos de desastre, inúmeras casas, escolas, igrejas, locais de uso público (praças, shoppings, mercados), estradas e empresas são completamente destruídas; o fornecimento de água, luz, gás e mantimentos fica comprometido; milhares de pessoas mortas, feridas, desabrigadas, desalojadas e tantas outras consideradas desaparecidas. Sendo assim, o impacto é coletivo e inegável, e a repercussão destas catástrofes passa a ser global a partir do momento em que estas são disseminadas pelos diferentes meios de comunicação hoje existentes. 
Com o avanço das tecnologias - em especial dos meios de comunicação - o acesso à informação têm nos proporcionado estar a par destes e tantos outros acontecimentos mundiais em questão de segundos onde quer que estejamos no momento em que estes ocorrem. Hoje é possível acompanharmos ao vivo eventos que estão se desenrolando a milhares de quilômetros de distância. Muitos assistem aos eventos em segurança dentro de suas casas, enquanto tantos outros estão ali, retratos de uma realidade que muitas vezes se repete ano após ano.

Por um lado, esta macroexposição pode otimizar o tempo de resgate, facilitar a comunicação com pessoas diretamente atingidas pelos desastres e melhorar a compreensão sobre o fenômeno em si; por outro, estamos cada vez mais vulneráveis a reportagens sensacionalistas, fotos e imagens fortes que podem chocar não só pela violência comum aos desastres, mas também pelo conteúdo das matérias veiculadas, que, por vezes, chegam a ofender os enlutados ou podem até mesmo transmitir informações imprecisas e/ou precipitadas, elevando a ansiedade e a tristeza dos que aguardam por notícias acuradas sobre a tragédia.

Diante deste quadro de acessibilidade total às ocorrências mundiais, no qual todos os desastres são noticiados pelos veículos midiáticos, pagamos um preço que é cobrado, de alguma forma, de todos nós. Trazemos esta questão pois nem só de sobreviventes diretos uma tragédia é composta. Nas últimas décadas, temos acompanhado em tempo real os diferentes acontecimentos ao redor do mundo e, como as informações são rapidamente disseminadas, ficamos também mais expostos quanto as nossas fraquezas na administração do caos e as limitações que possuímos em relação à assistência que prestamos aos sobreviventes. Somos todos impactados pelas catástrofes pois elas nos remetem a nossa própria finitude e à fragilidade do mundo em que vivemos (PARKES, 2009).

Apesar deste acesso livre a todo e qualquer tipo de informação, é evidente que um dos pontos de maior debate na atualidade são os recorrentes eventos climáticos de ampla magnitude devido, principalmente, aos crescentes e devastadores impactos individuais, financeiros e sociais nos diversos países em todos os continentes. Nunca se falou tanto sobre aquecimento global, desenvolvimento sustentável, reciclagem, produção de energia verde, entre outras estratégias para tentar amenizar os impactos destes fenômenos que trazem tanta destruição e dor à população. 
Mesmo diante desta preocupante realidade onde muitos são brutalmente atingidos, ainda assim carecemos de mais estudos na área das Ciências Humanas. Ciências como a Geologia, Geografia, Meteorologia, Física e até mesmo Economia possuem diversas produções sobre os impactos ambientais, sociais, financeiros e até mesmo populacionais dos desastres, as quais enriquecem muito a discussão sobre o tema, e as pesquisas na área de Psicologia precisam acompanhar esta evolução, já que são de extrema importância não só para aprimorarmos ainda mais os conhecimentos dos profissionais que trabalham direta e indiretamente com os enlutados das tragédias, mas também para encontrarmos novas estratégias relacionadas à prevenção e promoção de saúde em situações de emergência.

A partir de todas estas reflexões, muitas perguntas emergiram: como é a experiência de vivenciar perdas múltiplas? Como compreendemos o desastre e que impactos estas perdas têm individual e coletivamente, já que os eventos (especialmente os climáticos) atingem centenas e até milhares de pessoas? E se, em decorrência deste desastre, um ente querido desaparece? É sobre esta dura realidade que assola milhares de pessoas todos os anos que esta tese se propõe. Queremos dar voz a pessoas que tiveram essa vivência e, a partir de seus discursos genuínos e emocionantes, mostrar aos leitores que essa é, na verdade, a realidade de todos nós.

Este estudo tem sua relevância neste ainda muito a explorar terreno de pesquisa. Pensar em cada sobrevivente e cada família enlutada é premente; admitir que centenas de pessoas são completamente desoladas por eventos catastróficos todos os dias é assustador, mas necessário; uma melhor formação dos profissionais que lidam diretamente com pessoas em situação de risco ou já no contexto do desastre se faz tão urgente hoje quanto a necessidade de aprimorarmos nossas estratégias de prevenção.

Gostaríamos de ressaltar também que esta reflexão busca indiretamente desmistificar a origem de catástrofes como a ocorrida na Região Serrana como um evento exclusivamente de origem climática, pois como vemos constantemente na mídia, nenhuma catástrofe ocorre sem a interferência humana, fazendo-se necessária uma espécie de "desnaturalização dos desastres naturais", ou seja, devemos repensar nosso olhar sobre as catástrofes e sempre avaliar o papel do homem por trás de cada desastre, seja quando atua (ou deixa de atuar) com 
prevenção e orientação a população, seja na forma como aloca seus recursos humanos e materiais antes, durante e depois de uma catástrofe e o quanto investe (não só financeiramente) no processo de reconstrução das comunidades atingidas.

Para atingir nossos objetivos e respeitando a complexidade do tema em questão, este trabalho partirá de alguns eixos, a seguir descritos: no Capítulo 1, iniciaremos nossa reflexão apresentando a Teoria do Apego, o conceito de luto e suas fases; no Capítulo 2, introduziremos os conceitos relacionados aos desastres, suas formas de classificação e os impactos comumente observados nestes contextos, além de informações sobre o desastre ocorrido na Região Serrana, ponto de partida de nosso; já no Capítulo 3, trataremos a especificidade do luto em casos de desastre e discorreremos mais aprofundadamente sobre os conceitos de perdas múltiplas e perda ambígua. Dando prosseguimento ao trabalho, são apresentados no Capítulo 4 os objetivos da pesquisa, a metodologia de trabalho ferramenta fundamental para a compreensão do fenômeno - assim como uma breve apresentação dos participantes e suas histórias. No Capítulo 5, apresentamos a discussão dos resultados contruída a partir da análise das 20 entrevistas coletadas com moradores de três cidades da Região Serrana atingidas pelas chuvas de janeiro de 2011 (Petrópolis, Teresópolis e Nova Friburgo). No Capítulo 6, finalizamos nossa reflexão com as Considerações Finais, apresentando algumas propostas e ideias a partir dos resultados observados. Por fim, em Anexo, temos o Roteiro Preliminar de Entrevista (Anexo 1) que serviu como norte para a realização deste estudo; o Termo de Consentimento Livre e Esclarecido (Anexo 2); e a Tabela de Participantes com a síntese dos dados de identificação de cada entrevistado (Anexo 3).

Aqui começa nossa jornada por tantas histórias... histórias sempre individuais e coletivas que ficarão para sempre marcadas pelas chuvas de janeiro de 2011. História esta que diz respeito ao estado do Rio de Janeiro e a todos que têm um vínculo com os municípios afetados; história esta que diz respeito a todos os que vivem em comunidades que já foram ou poderiam ter sido devastadas por chuvas como esta; história esta que diz respeito a todos os que moram em um país onde as políticas de planejamento das cidades, de divisão orçamentária, de saúde, moradia, educação e distribuição de renda são precárias; história esta que diz respeito ao mundo, cada vez mais assolado pelos diferentes eventos climáticos, 
em muito influenciados pela relação do homem com o meio ambiente... e assim, história esta que diz respeito a cada um e a todos nós... são histórias de dor, de luto, mas também de luta, solidariedade e muita perseverança, o que torna nosso percurso ainda mais humano. 


\section{1. É POSSÍVEL DIZER ADEUS?}

A vida é sempre incerta. A morte incerta é sempre certa. Morrer é fatal, necessário, inelutável. A morte está inscrita na própria natureza da vida.

(MORIN, 1980)

Ao longo da História, o homem imprime sua marca a todo instante ao escrever novos e importantes capítulos de sua própria história, esta sempre individual e coletiva. Podemos observar que, em toda trajetória humana, se por um lado, fazemos novas descobertas em prol da espécie e inovamos nossas tecnologias, por outro também reduzimos cada dia mais nossos recursos naturais e tornamos mais evidentes as desigualdades sociais. Apesar de todo o dinamismo presente em nosso cotidiano, rendemo-nos, ao final, a única indiscutível certeza da vida: nossa finitude.

Como seres mortais, deparamo-nos com a inegável realidade de nossa perenidade, e não estamos cercados apenas por nossa própria morte, mas também pelos diversos acontecimentos que nos remetem a diferentes tipos de perdas, as quais fazem parte de nosso dia a dia (KOVÁCS, 1992). Vivenciamos perdas em todos os momentos de nosso processo de desenvolvimento - seja porque, quanto mais envelhecemos, mais transformações sofremos - ou mesmo em situações como quando perdemos um animal de estimação, quando trocamos de colégio ou de trabalho, quando mudamos de casa, quando nosso time de futebol perde uma final de campeonato, quando perdemos o prazo para a inscrição no vestibular... seria impossível enumerar todas as situações as quais estamos sujeitos ao luto, mas cabe dizer que estas são, em geral, experiências universais e que, ao mesmo tempo, são vivenciadas de forma única, e fazem parte da história particular de cada ser humano (KOVÁCS,1992; PARKES, 1998, 2009; FRANCO, 2005).

Situações como as descritas anteriormente nos remetem a presença de morte na vida e, assim como nos casos de falecimento, estas perdas cotidianas podem suscitar sentimentos tais como medo, angústia, dor, sofrimento, raiva, entre outros, o que nos permite afirmar que não é preciso morrer concretamente para que esses sentimentos estejam presentes. 
Sejam quais forem as perdas, estas exigem sempre um trabalho de elaboração e serão processadas pelo sujeito a partir de suas experiências anteriores e seus recursos internos e, por isso, o tempo de reestruturação e reorganização é individual e imprevisível, já que “... a dor do luto é tanto parte da vida quanto a alegria de viver; é talvez, o preço que pagamos pelo amor, o preço do compromisso" (PARKES, 1998, p. 22). O ser humano procura se defender dessa dor utilizando-se de diferentes mecanismos. Dentre eles, o autor cita a agressividade, recurso pelo qual o sujeito ataca o que perdeu, transformando o amor em ódio em vistas de conseguir se desligar do objeto de apego; ou mesmo a indiferença, que pode surgir em meio ao desespero. A busca por novas atividades como substituição ao que foi perdido também pode ser uma estratégia para lidar com o sofrimento.

Isto ocorre sempre que sofremos uma perda significativa, e todos devemos passar por este processo de restabelecimento de nossas vidas perante as mudanças que irão se instaurar com a ausência de um objeto amado. Perdas abalam uma estrutura que até então considerávamos conhecida provocando uma ruptura, e demandam tempo para que possamos dar sentido a essa experiência em nossas vidas. Kovács (1992), ainda a esse respeito, afirma que quando perdemos algo ou alguém (seja em vida ou pela própria morte em si), consequentemente passaremos por uma série de etapas inerentes ao luto, tais como a negação da perda, raiva pela ausência do objeto de amor (ou mesmo direcionada aquele(a) que foi perdido(a)), barganha (tentativa de negociar a perda, tamanho é o desejo de reaver o objeto perdido), depressão e finalmente a aceitação e gradativa retomada da vida.

Kovács (1992) afirma também que, inevitavelmente, todos os seres humanos viverão, em algum momento de sua história, alguma situação de separação - em alguns casos pela morte em si - mas há também muitas experiências de separação entre vivos, e esta pode ser uma das vivências mais penosas em nosso processo de desenvolvimento. Segundo a autora, essa experiência pode vir a ser mais temida que a própria morte por ser vivida conscientemente em toda sua intensidade. Sob este olhar, as perdas nos fazem pensar na morte mesmo que esta não tenha ocorrido concretamente, e trazem muitos sentimentos comumente associados à morte, tais como dor, ruptura, interrupção, desconhecido e tristeza. 
Mas por que é tão difícil lidar com a perenidade das coisas e das pessoas? Por que temos tanta resistência em aceitar que aquele(a) ou aquilo a que temos apreço se vá? Muitos estudiosos envolveram-se com a temática do luto e, para analisarmos a questão mais a fundo, nos utilizaremos da Teoria do Apego, além de referir diferentes autores dedicados ao estudo do tema das perdas e lutos.

\subsection{Teoria do Apego - por uma vida com os outros}

Para a maioria das pessoas, o amor é a fonte de prazer mais profunda da vida, ao passo que a perda daqueles que amamos é a mais profunda fonte de dor. Portanto, amor e perda são duas faces da mesma moeda. Não podemos ter um sem nos arriscar a outro.

(PARKES, 2009)

O luto, como já referido anteriormente, não está relacionado única e exclusivamente à morte, mas sim ao grau de investimento afetivo estabelecido entre o eu e o que é ou quem é perdido, e deve ser compreendido, principalmente, como uma reação frente ao rompimento dos vínculos. Sob esta perspectiva, quanto maior a vinculação, a importância da união estabelecida e o investimento libidinal em um objeto, maior a energia necessária para o desligamento no caso de perda do mesmo.

Bowlby, em seu livro Formação e Rompimento dos Laços Afetivos (1998), afirma que todos os seres vivos estabelecem relações de apego ao longo da vida, pois apegar-se é um instinto natural de formar laços com outros pares. O estabelecimento de vínculos está relacionado não só ao ato de ligar-se a objetos importantes, mas também ao desenvolvimento de estratégias de manutenção desses laços com as figuras eleitas quando enfrentamos situações de estresse, doença ou medo. Essas relações amorosas são importantes para nossa sobrevivência não só do ponto de vista físico, mas também emocional e social. É a partir deste comportamento de apego que estabelecemos os vínculos, os quais possuem uma dupla função: transmitir segurança e dar continência a ambas as partes. 
Em seus primeiros estudos, Bolwby (1989) realizou pesquisas as quais comprovaram que nos mamíferos - em especial nos primatas - o primeiro e mais persistente vínculo é geralmente estabelecido entre mãe e filhote (lembrando que a figura da mãe deve ser entendida como a do(a) cuidador(a) primário(a) do bebê). As funções básicas da vinculação em todas as espécies são nutrição e reprodução, mas esta também se refere à proteção contra predadores. $\mathrm{O}$ autor atesta que, embora esta vinculação afetiva seja resultado do comportamento social de cada indivíduo, em geral, ambos tendem a se manter próximos e, quando se separam, em algum momento, procuram por este outro novamente. $\mathrm{O}$ autor sugere ainda que os vínculos afetivos se desenvolvem devido à forte inclinação das criaturas a se aproximarem de classes de estímulos que lhes são familiares e, em contraposição, evitarem as que lhes são estranhas.

Os instintos de proteção, alimentação e sobrevivência da espécie também estão presentes nos seres humanos, mas há uma diferença primordial no processo de formação dos laços: somos "atravessados" pela linguagem e pela cultura. O apego na espécie humana também está relacionado às trocas afetivas entre as figuras eleitas e o bebê, mas esta interação será marcada pelo comportamento de ambas as partes, tornando assim fundamentais os fatores que antecedem e influenciam este vínculo, como por exemplo, o significado da criança na vida desta família (BOLWBY, 2002).

A partir da formação destes laços afetivos se estabelece o chamado Modelo Funcional Interno (BOLWBY, 1998). Este modelo serve como base para as primeiras e também para as futuras relações afetivas dos seres humanos. A criança que possui um modelo seguro de apego tende a desenvolver expectativas positivas em relação ao mundo, acreditando que suas necessidades possam e serão supridas. Já uma criança que tenha como referência um modelo menos seguro poderá desenvolver expectativas negativas em sua relação com o mundo e, baseado neste tipo de vinculação, comprometer o estabelecimento de suas relações posteriores.

Sob esse aspecto, quando o apego possui uma base segura, a presença da figura principal oferece estabilidade e conforto, e a criança sente-se apta a conhecer e desbravar o mundo. Em situações onde não existam ameaças aparentes, a criança pode partir em um comportamento exploratório ativo, reconhecendo o ambiente e a ele se integrando. 
Há também a função de "porto seguro", como quando de fato existe uma ameaça imediata no ambiente e a criança pode voltar-se em busca de segurança na figura de apego e será bem sucedida. O apego, desta forma, é um sistema de regulação mútua entre as figuras de referência e bebês, cuja função básica é prover proteção ao membro mais vulnerável da díade através dessa proximidade com o cuidador (BOLWBY, 2002).

Além da função reguladora, o apego também deve: desenvolver a confiança básica e reciprocidade que servem como base para futuros relacionamentos; permitir que a criança explore o espaço com segurança, o que possibilita um desenvolvimento cognitivo e emocional saudável; desenvolver habilidades para o autocontrole, o que resultará em manejos mais eficientes dos impulsos e emoções; criar uma base sólida para a formação da identidade, incluindo senso de competência, autovalorização e equilíbrio entre dependência e autonomia; estabelecer uma estrutura moral pró-social que envolve empatia, compaixão e consciência; gerar um sistema de crenças nuclear que compreende estimar a si mesmo, cuidadores e os demais; e, por fim, prover defesas contra estresses e traumas, fortalecendo os recursos internos e a capacidade de resiliência.

Já Ainsworth (1978) nos alerta quanto aos casos nos quais a base do apego não é segura. No momento em que uma díade estabelece uma relação, a figura de referência pode não trazer sustentação e confiança na relação com o bebê, gerando sentimentos como medo, angústia e desamparo. Esta base insegura, segundo a autora, não impede a formação do vínculo, mas pode influenciar negativamente no estabelecimento de novas relações, o que leva a estilos de apego disfuncionais. Segundo seus estudos, poderíamos elencar dois tipos de apego inseguro:

- Apego inseguro/evitativo: podem ser observados em crianças que, ao procurar o apoio do cuidador, não encontram uma resposta positiva e sim rejeição, tendendo a mostrar como defesa uma atitude de autossuficiência emocional, evitando contatos mais íntimos;

- Apego inseguro/ambivalente: crianças respondem com comportamentos ansiosos, tais como abraçar, apertar, chorar e/ou demonstrar hipersensibilidade a afetos negativos, pois não sabem se o cuidador estará disponível quando procurado, tendendo a apresentar ansiedade de separação. 
De acordo com os autores (AINSWORTH, 1978; BOLWBY, 1998, 2002), o apego se mantém mesmo nos casos de relações abusivas ou quando há negligência por parte do cuidador principal. Dentre as causas para o apego disfuncional, os autores citam ainda os cuidados ineficientes ou insensíveis; casos de depressão; distúrbios psicológicos severos ou crônicos; problemas congênitos do bebê; ausência prolongada da figura de apego (decorrentes de hospitalização, encarceramento ou morte); abuso de substâncias; pais adolescentes ainda em processo de amadurecimento físico e emocional; e nascimento prematuro (onde mãe e bebê ainda não estão prontos). Há ainda os fatores contextuais que podem interferir na vinculação, tais como violência, falta de suporte, mudanças constantes de moradia, conflitos conjugais ou mesmo falta de estimulação.

Como vimos, a formação de vínculos (seja esta com figuras de apego seguras ou inseguras) é a base para compreendermos a importância do outro na vida de cada ser vivo. Todos os seres humanos elegem objetos de referência e formam com estes laços que servirão de modelo para os relacionamentos futuros, pois como afirma Bolwby (1998), “... não sentimos amor e nem pesar por um ser humano qualquer, mas apenas por um ou alguns seres humanos em particular" (p. 96). Em contrapartida, os eleitos fornecerão a base - segura ou insegura - para lidarmos com as perdas inerentes a nossa condição humana (especialmente nos casos nos quais todos os nossos recursos forem exigidos). Em outras palavras, estamos sempre conectados a pessoas e objetos escolhidos e amados e, consequentemente, quanto maior o investimento libidinal em uma figura de apego, maior será a energia necessária para o desligamento e, consequentemente, para elaborar esta perda.

\subsection{Luto: o preço que pagamos pelo afeto que trocamos}

O amor é um vínculo com uma pessoa específica apenas (...) as pessoas não são substituíveis e cada novo relacionamento será único, por si. Por esse motivo, o valor de cada pessoa que amamos é incalculável. Não podemos avaliá-las como fazemos com objetos utilitários ou passíveis de reposição.

(PARKES, 2009) 
Quando falamos em luto, estamos falando sobre uma perda única vivida por um sujeito único em um momento único de seu ciclo vital. Parkes (1998) nos diz que, apesar do luto ser uma reação natural e universal às perdas (e estas serem corriqueiras em nossas vidas), cada indivíduo reage de um jeito particular, próprio e isso é o que nos torna ainda mais especiais (e, como ele mesmo descreve, insubstituíveis). Segundo o autor, o termo luto é mais comumente utilizado para descrever o processo que iniciamos após morte de uma pessoa amada; no entanto, como vimos anteriormente, perdas podem ser de naturezas diversas e a pessoa enlutada, investida afetivamente naquilo ou naquele(a) que foi perdido(a), sentirá essa ausência, mesmo que temporariamente, como uma perda de parte de si mesma.

Freud, no texto Luto e melancolia (1917), foi um dos primeiros autores a introduzir o conceito de luto em seus estudos. No texto, o autor aponta o processo de vinculação entre os seres humanos como basilar para a constituição do sujeito e, em decorrência desta forte ligação amorosa, quando um dos membros da díade se faz ausente, o sofrimento é inevitável. Este processo de enlutar-se, segundo o autor, é particularmente doloroso, mas necessário pois, em sua jornada pela dor da perda, o sujeito pode se redescobrir e reinventar. No entanto, Freud nos alerta sobre duas formas possíveis de enfrentarmos a ausência do objeto de amor: o luto ou a melancolia.

No luto, identificamos uma intensa resposta emocional à separação e ao rompimento dos vínculos. Estas repostas são reações à perda real de um objeto de amor, no qual havia um intenso investimento libidinal. Quando o objeto é perdido, o enlutado gradativamente deve retirar a libido de todas as ligações com este. $\mathrm{O}$ luto é caracterizado por momentos de grande tristeza e dor que, em geral, são expressas e descarregadas, o que possibilita, posteriormente, que o indivíduo desinvista do objeto de amor perdido, tornando a libido novamente disponível, agora para relações futuras. Neste processo normal, Freud (1917) afirma que o chamado teste de realidade revela ao sujeito que o objeto não mais existe, tornando imprescindível à renúncia dos laços com este para que, com o tempo, a energia libidinal possa ser reinvestida em um novo objeto. Este desenlace é executado pouco a pouco, com grande dispêndio de tempo e de energia catexial. 
Já na melancolia, a perda não é só do objeto, mas também de si próprio. O amor sobre o que ou quem se perdeu não pode ser abandonado e o enlutado se identifica com este, incorporando-o. Em outras palavras, a pessoa permanece fixada ao objeto perdido, tentando negar a realidade da perda, pois a separação significa dor insuportável. O enlutado permanece ligado ao que ou a quem foi perdido, prejudicando (ou até mesmo impossibilitando) o estabelecimento de novas relações. A melancolia, portanto, se caracteriza por uma impossibilidade de substituição do objeto de amor, pois isto significaria aceitar a perda de si mesmo.

... na melancolia, a perda não é só do objeto, mas da própria pessoa. A libido livre se volta para o próprio Eu. $\mathrm{O}$ amor sobre o objeto não pode ser abandonado e o Eu, para não sucumbir, estabelece uma identificação com o objeto perdido, incorporando-o (...) a pessoa tem uma tendência a se agarrar ao objeto perdido, tentando com isso negar a realidade da perda, pois a separação significa dor. Se a dor não for expressa pela tristeza, a separação é incompleta e o Eu permanece ligado ao objeto perdido, prejudicando o estabelecimento de novas relações. É uma forma de inexistência que atesta a recusa da separação, uma impossibilidade do sujeito de substituir o objeto de amor (SARAIVA, 1999, p.71).

Tanto o luto como a melancolia são caracterizados por um estado depressivo que têm como sintomatologia fundamental “... desânimo profundamente penoso, a cessação de interesse pelo mundo externo, a perda da capacidade de amar, a inibição de toda e qualquer atividade...” (FREUD, 1917, p.250). No luto, apesar deste processo ser muito doloroso, quando concluído, deixa o ego livre novamente - processo este que não tem duração determinada e variará de acordo com o grau de ligação afetiva que a pessoa estabelecia com o objeto. Já na melancolia, a pessoa mantém-se presa ao objeto agora ausente, negando a perda e não se permitindo estabelecer novos vínculos.

A experiência da perda assemelha-se, deste modo, no transformar em vazio todo o processo de vida. Perdido na própria perda o objeto faz com que a privação, através da compulsão à repetição, se torne em determinação, contaminando o futuro como um espaço vazio. Vazio estereotipado (...) que parece consumir o indivíduo melancólico em uma eterna nostalgia de um mundo compartilhado. Saudade de uma ilusão, proporcionada pela destituição do objeto perdido em uma perda sem objeto (KOURY, 2001, p.55). 
Teóricos mais contemporâneos (PARKES, 1998, 2009; BROMBERG, 2000; STROEBE \& SCHUT, 2001; WORDEN, 2001; BOWLBY, 2004) definem o luto como um processo muito singular a que todos os humanos estão sujeitos em diferentes etapas do desenvolvimento. O luto não é linear e não pode ser entendido meramente como um conjunto de sintomas que surgem a partir de uma perda importante e desaparecem com o passar de um tempo predeterminado. De acordo com estes autores, devemos compreender o luto como um processo de adaptação complexo frente a uma nova realidade, o qual é atravessado por intensas oscilações emocionais e comportamentais.

O sujeito precisa lidar com a realidade da perda e com os sentimentos e emoções decorrentes desta, ao mesmo tempo em que deverá reaprender a viver apesar de todas as mudanças, de forma que possa reconstruir sua vida. Parkes (1998) compara o luto a uma ferida física que, aos poucos, se cura. Esse processo de cicatrização é muito particular e importante na vida das pessoas enlutadas, especialmente porque cada indivíduo possui características próprias para processar suas perdas.

O luto, ainda segundo o autor, é uma necessidade psicológica que possibilitará a elaboração frente às mudanças e à falta do objeto perdido, mas que, por um tempo, nos afasta de nossa dinâmica usual - um período que quase não nos reconhecemos e certamente não reconhecemos nosso mundo como antes. Nossa segurança é abalada e nossos sentimentos ficam confusos; é uma jornada que pode parecer sem fim, no qual somos tomados pela sensação de que nada mais faz sentido e de que a sensação de vazio não cessará.

Durante esse processo, tentamos dar sentido a tudo que nos aconteceu e, apesar de já não sermos mais os mesmos, o mundo se torna cada vez menos nublado e podemos nos adaptar à nova realidade, encontrando um lugar para o que ou quem perdemos. No curso normal do luto, por mais que nada seja como antes, a saudade, as lembranças e outros sentimentos positivos nos mantêm ligados aquele(a)/aquilo que não está mais presente, mas isso não quer dizer que podemos nos paralisar, pois como afirma Casellato (2005), este processo de elaboração “... é necessário na medida em que nós precisamos dar sentido ao que aconteceu em nossas vidas e retomarmos o controle sobre nós mesmos, sobre o mundo e sobre as relações afetivas" (p.20). 
Parkes (1998) ressalta ainda que o luto pode ser compreendido como uma sucessão de quadros clínicos que se mesclam e se substituem, e dentro deste emaranhado complexo de reações à perda, podemos identificar características distintas em cada uma de suas fases - embora, obviamente, devamos respeitar as diferenças individuais de uma pessoa para outra, tanto no que se refere à duração quanto às reações a cada etapa do processo. Este processo ocorre sempre que vivemos uma perda, mas é fundamental percebermos como esta elaboração ocorre - daí a importância de entendermos os processos de luto normal e patológico.

\subsection{O luto / a luta}

A perda do amado é uma ruptura não fora, mas dentro de mim.

(NÁSIO, 1997)

O luto é, indubitavelmente, uma crise, no sentido que ocorre um desequilíbrio entre a quantidade de ajustamento necessária de uma única vez e os recursos imediatamente disponíveis para lidar com a(s) perda(s) (BROMBERG, 2000). Ao retomarmos a questão do apego e o papel da base segura (ou insegura) sob a qual alicerçamos nossas relações, estamos apontando para o fato de que é justamente no momento de uma perda importante que buscamos, interna e externamente, os recursos para o enfrentamento frente à ausência de um objeto amado. Diante da dor e da desorganização comumente presentes em situações de perda, apresentamos reações e comportamentos muitas vezes aprendidos e desenvolvidos a partir da relação com nossas primeiras figuras de referência, e estes modelos podem desencadear o que Freud (1917) já havia denominado como reações de luto normal ou luto patológico.

Estudos mostram uma série de sintomas relacionados ao processo de luto considerado normal. Para Franco (2002), uma perda significativa pode desencadear uma série de reações nos âmbitos intelectual (déficit de memória e concentração, confusão, desorganização, intelectualização, desorientação, negação, sensação de despersonalização); emocional (choque, entorpecimento, 
raiva, culpa, alívio, depressão, irritabilidade, solidão, saudade, descrença, tristeza, ansiedade, medo); físico (alterações de apetite, sono e peso, inquietação, dispneia, hipersensibilidade a luz e a sons, palpitação, perda de libido, choro, consumo de substâncias psicotrópicas, álcool e fumo, "vazio" no estômago, "aperto" no peito, "nó na garganta", falta de ar, fraqueza muscular, falta de energia, boca seca, suscetibilidade a doenças, em especial às relacionadas à baixa imunidade); espiritual (perda ou aumento na fé religiosa, questionamentos sobre fé, valores e Deus); e social (perda de identidade, isolamento, afastamento e retraimento).

Ainda sobre as possíveis reações relacionadas ao luto normal, Bromberg (2000) cita o estudo de Strobe \& Strobe (1987) no qual os autores elencaram como possíveis sintomas: depressão, ansiedade, culpa, raiva, hostilidade, falta de prazer e solidão. Com relação às manifestações fisiológicas foram relatados agitação, fadiga e choro. Ainda em relação às queixas somáticas foram descritos perda de apetite, distúrbio de sono, perda de energia, dores no corpo, mudanças na ingestão e susceptibilidade a doenças. As respostas comportamentais mais citadas em relação a si, ao falecido e ao ambiente foram baixa autoestima, desamparo, problemas de relacionamento e atitudes negativas em relação ao morto. No que diz respeito à deterioração cognitiva, foram identificados lentidão de pensamento e da concentração, dificuldades de memorização e desatenção.

Parkes $(1998,2009)$ ressalta que em qualquer luto raramente fica claro o que de fato foi perdido em decorrência do grande número de perdas secundárias, o que pode dificultar ainda mais o processo de elaboração. O trabalho de luto consiste em aceitar a realidade da perda vivida, elaborar a dor da mesma, ajustarse ao ambiente onde o objeto perdido não mais se encontra e reposicionar-se emocionalmente em relação a este, podendo dar continuidade à vida. Essas mudanças levam tempo e não são apenas individuais, mas também sociais, em especial no núcleo familiar, já que todos são afetados pela perda.

Bromberg (2000) afirma que, em nosso processo normal de enfrentamento diante de uma perda, passamos por diferentes etapas, dentre as quais:

... uma fase inicial de choque e descrença, na qual a pessoa tenta negar a perda e se isolar contra o choque da realidade. A seguir, vem uma fase de crescente consciência da perda, marcada por efeitos dolorosos de tristeza, culpa, vergonha, impotência e desesperança; há também o choro, uma sensação de vazio, distúrbios 
de alimentação e de sono, às vezes alguns distúrbios psicossomáticos associados à dor física, perda de interesse pelas companhias ou atividades costumeiras, perda da qualidade nas atividades profissionais. Por fim, há uma prolongada fase de recuperação, na qual se dá a elaboração do luto, o trauma da perda é superado e é restabelecido um estado de saúde (p. 31).

Ainda sobre as fases descritas no chamado luto normal, a autora faz referência a possíveis reações, sentimentos e sintomas em cada etapa deste processo:

1- Entorpecimento: conjunto de reações iniciais à perda, esta pode ser descrita como uma fase marcada por choque, incredulidade, descrença e negação. A duração pode ser de poucas horas ou muitos dias. A pessoa recentemente enlutada se sente perdida, atordoada, desamparada e, muitas vezes, paralisada. Entre os sintomas somáticos podem-se observar respiração ofegante, rigidez no pescoço e sensação de vazio no estômago. A negação inicial da perda pode ser uma forma de defesa do sujeito, sendo comum nesta fase a tentativa de continuar vivendo como se nada houvesse acontecido, já que o enlutado apresenta dificuldades para entrar em contato com esta nova realidade (especialmente nos casos de perdas inesperadas e abruptas);

2- Anseio e protesto: fase de fortes emoções, com muito sofrimento psicológico e agitação física. À medida que se concretiza a realidade da perda, há um aumento do desejo de reencontrar o objeto perdido. Nesta etapa podemos experienciar crises de profunda dor e choro incontrolável. Apesar da consciência de sua irreversibilidade, o desejo de recuperar o que foi perdido pode parecer insuperável. Há momentos em que o enlutado afirma ter a certeza de ainda sentir a presença de quem (ou do que) se foi. A pessoa pode ficar mais afastada, calada e introvertida. Também é comum que nesta fase o enlutado sinta raiva, podendo ser auto ou heterodirigida, na forma de acusações repletas de sentimentos de culpa por pequenas omissões e cuidados que possam ter acontecido; a raiva também pode ser dirigida ao morto, pois o enlutado sente-se abandonado. A principal característica dessa fase é que a pessoa enlutada movimenta-se sem descanso, como em busca do que foi perdido e mostra-se obsessivamente preocupada com lembranças, pensamentos e objetos que tenham ligação direta com aquilo/aquele (a) que se perdeu; 
3- Desespero: o enlutado reconhece a imutabilidade da perda e deixa de procurar pela pessoa perdida; é possível que o sujeito passe a questionar se a vida vale a pena e se deve continuar sua jornada agora sem o objeto amado (fase de maior apatia e depressão). O processo de superação é bastante lento e doloroso. O afastamento das pessoas e das atividades regulares pode ocorrer, assim como falta de interesse em envolver-se com quaisquer atividades ou pessoas. Outra possível reação é descrita como uma inabilidade em se concentrar em atividades cotidianas ou mesmo iniciar novas tarefas. Os sintomas somáticos também estão presentes tais como falta de sono, perda de apetite e de peso, distúrbios gastrointestinais, entre outros;

4- Recuperação e restituição: a depressão e a desesperança começam a ser substituídas por sentimentos mais positivos e menos devastadores. O enlutado passa a aceitar as mudanças em si e na realidade. Começa a surgir uma nova identidade que lhe permite desinvestir da ideia de recuperar o objeto perdido. Retoma-se o senso de independência e iniciativa. Apesar dos relacionamentos sociais ainda estarem fragilizados, o enlutado volta-se para o mundo e começa a buscar novas amizades e a reatar laços do passado. No entanto, é possível que ocorra a remissão de sintomas que já haviam cedido, particularmente em datas especiais como aniversário de nascimento, de morte ou de casamento (fenômeno conhecido como reação de aniversário).

Fukumitsu (2004) afirma que as situações de perdas geralmente levam a uma sensação de caos, mas estes são eventos transitórios em nossas vidas e não representam um fim; segundo a autora, estas etapas devem ser compreendidas como uma fase crítica que demanda um fechamento (no inglês, closer). Parkes (1998) acredita que a base do luto complicado está justamente na resistência às mudanças que esta nova etapa do ciclo vital nos impõe, e apresenta como características do luto normal as seguintes etapas:

1. Primeiras reações: diante de uma perda significativa, notamos reações de alarme, inquietação, ansiedade e reações fisiológicas que acompanham o medo tais como sudorese, tremor ou paralisia; após o choque inicial, raiva e culpa se fazem presentes, podendo incluir atitudes agressivas contra aqueles que pressionam o enlutado a aceitar rapidamente sua perda; 
2. Pesar: necessidade premente de procurar e encontrar o objeto perdido, podendo culminar no fenômeno denominado de "identificação" que consiste na adoção de traços, maneirismos ou sintomas da pessoa perdida (especialmente nos casos em que a morte do ente querido se deu em decorrência de problemas crônicos de saúde);

3. Transição Psicossocial: sensação de deslocamento entre o mundo real e o mundo desejado ou sensação de mutilação e vazio. Estes sintomas apontam para a necessidade de o indivíduo reavaliar seu modelo interno de mundo; uma espécie de autoavaliação, tendo como principal objetivo se perceber e compreender a maneira pela qual se move da negação e evitação do reconhecimento da perda para a aceitação e adoção de um novo modelo de mundo.

Como já referimos anteriormente, a experiência de pessoas enlutadas possui características próprias, mas o modelo de fases apresentado pelos autores supracitados procura agregar alguns pontos comuns deste processo de enfrentamento. Vale ressaltar, no entanto, que todos enfatizam que a vivência emocional do luto não é linear e existem muitas diferenças entre os indivíduos, e por esta razão nem os sintomas nem as fases do luto serão necessariamente vivenciados por todos, muito menos da mesma maneira.

A intensidade do pesar e a duração de cada fase são muito particulares e estão relacionados a uma série de fatores individuais e imprevisíveis. Diante de uma situação de perda, o enlutado se utilizará de recursos que possam auxiliá-lo no processo de enfrentamento da mesma, através de mecanismos de coping. Miguel e Bueno (2007) afirmam que coping é o conjunto de estratégias disponíveis para lidar com situações adversas ou estressantes que exigem dos sujeitos um esforço tanto cognitivo como comportamental, e completam:

A resposta de coping então se define por uma ação intencional, física ou mental, iniciado em resposta a um estressor percebido, podendo ser direcionado tanto a situações externas quanto a estados internos do individuo, ou seja, envolvendo uma reação emocional ou comportamental espontânea, orientada para a redução do estresse gerado pela demanda (p.4).

O mecanismo de coping pode resultar em respostas bem-sucedidas diante de situações de estresse e de perdas mas, segundo Lazarus e Folkman (1984 apud 
KRUM, 2007), este é um processo em constante transformação pois nem todas as nossas estratégias se adaptam diante de todo e qualquer evento estressor, e por isso devem ser constantemente revistas e desenvolvidas.

O objetivo deste conjunto de estratégias é, segundo os autores, reduzir o desconforto diante do evento estressor, o que pode ocorrer através de distanciamento, minimização dos fatos, atenção seletiva, atribuição de valor positivo a situações negativas, autocontrole ou até mesmo evitação - essas são as chamadas estratégias de coping focalizadas na emoção, comumente associadas ao desejo de manter a esperança e o otimismo. Há ainda as estratégias de coping focadas no problema, ou seja: o emprego de recursos e esforços diretamente no fato gerador de estresse, de forma a alterá-lo. A ação pode ser autodirigida (reestruturação cognitiva) ou para o ambiente (busca de recursos ou agressividade, por exemplo).

Um aspecto diretamente relacionado às estratégias de enfrentamento (coping) é a chamada resiliência. Resiliência é um termo originalmente utilizado pela Física e significa a capacidade de um material voltar ao estado normal depois de submetido a uma grande e forte pressão. A esta pressão também podemos chamar de estresse, como explica Passos (2013):

A palavra stress, traduzida como tensão ou pressão (...) serve não só para designar a sensação ou sentimento de estar cansado ou irritado, como também para descrever respostas (sensações) desagradáveis que ocorrem no corpo ou na mente quando um individuo enfrenta uma situação desafiadora, enfim, ao sofrer uma pressão (interna ou externa) a ponto de causar um desgaste físico ou emocional. O termo inicialmente usado na física, refere-se ao grau de deformidade sofrido por uma estrutura quando submetida a um esforço ou pressão. A medicina incorporou este termo na década de 1930, através do médico Hans Selye, para nomear um conjunto de reações fisiológicas desenvolvidas pelo organismo ao ser submetido a uma situação que exige um esforço adaptativo (p.32).

Quando falamos em resiliência nos casos de luto, segundo Walsh (2003), estamos nos referindo, segundo a autora,

... a capacidade de reagir à adversidade, ficar mais forte e com mais recursos. É um processo ativo de resistência, autorrecuperação e crescimento em resposta à crise e ao desafio (...) é a habilidade para suportar e reagir aos desafios da vida (p.4). 
Diante de perdas importantes, acionamos nosso repertório interno e utilizamo-nos de diferentes recursos de enfrentamento para suportar e elaborar os lutos vividos e esta capacidade de reagir à ausência do objeto de amor é sempre um processo em construção, pois ao desenvolvermos estas habilidades, fortalecemo-nos e nos tornamos ainda mais resilientes em casos de perdas futuras. A resiliência é um constante aprendizado diante de situações desafiadoras e leva a uma transformação do próprio sujeito em sua relação consigo mesmo e com o ambiente, permitindo que este desenvolva ainda mais seu repertório interno.

Portanto, a capacidade de reestruturação e elaboração de cada indivíduo diante de perdas importantes está diretamente relacionada à capacidade de ser resiliente e aos recursos de autoavaliação e autorregulação diante de situações difíceis; porém, não podemos esquecer que as pessoas experimentam diferentes níveis de estresse em diferentes contextos. A identificação de um evento como estressor não determina a instalação de um quadro de estresse, a não ser que o individuo perceba e avalie este acontecimento como tal (HOBFOLL, 1998). Segundo Passos (2013), características pessoais e situacionais irão influenciar diretamente neste julgamento, os quais também estarão associados o tempo de exposição ao evento (curto, breve, repetido ou prolongado) e a intensidade, magnitude e criticidade do mesmo (se leve, moderado ou severo).

A partir desse levantamento sobre o tema, podemos concluir que o luto é uma vivência muito peculiar na vida dos seres humanos e processo de elaboração é fundamental para a manutenção da saúde mental daqueles que sofreram perdas significativas. Quando este processo transcorre de forma adequada, proporciona à pessoa enlutada a possibilidade de reconstrução de seu mundo e o fortalecimento seus próprios recursos, adaptando-se a cada novo dia à perda e à nova realidade, investindo em novos relacionamentos e objetos. $\mathrm{O}$ enlutado consegue encontrar um lugar em sua vida para aquele(a)/aquilo que perdeu, mas não fica paralisado e preso a este, podendo dar, enfim, continuidade a sua vida.

Para Landau (1982 apud KLINGMAN \& COHEN, 2004), nossa capacidade de sermos resilientes é uma característica que se perpetua no ciclo familiar e é fundamental que tenhamos capacidade de transmitir através das gerações nossos recursos biológicos, psicológicos, sociais e espirituais para lidar com os impactos e as consequências dos traumas, já que esta transmissão transgeracional possibilita 
a recuperação e, posteriormente, a cura não só no presente, mas também para os futuros membros da família; caso contrário, tendemos a perpetuar sentimentos como medo, desamparo e impotência.

Sob esta ótica, quando vivemos uma perda, essa não é vivida apenas pelo sujeito individualmente. A premência de uma elaboração da perda da relação com o que/quem foi perdido também ocorre dentro do ambiente em que estamos inseridos, especialmente, no núcleo familiar; desta forma, nenhuma relação significativa é esquecida, mas sim resignificada para cada membro e para o grupo, como veremos a seguir.

\title{
1.4 Luto na família e na comunidade - unidos venceremos?
}

\begin{abstract}
A família é um sistema com propriedades diferentes de outros, pois se movimenta através do tempo com a entrada e a saída de seus membros e, consequentemente, assume desafios e estresses gerados com a mudança da estrutura, das funções e dos papéis que permitem que esse sistema opere com mais ou menos pessoas.
\end{abstract}

(CARTER \& McGOLDRICK, 1995)

Perdas fazem parte da vida de cada um de nós, mas também atingem as famílias e a sociedade na qual vivemos. Em nosso ciclo vital, estamos expostos a diversos estressores, alguns previsíveis, outros imprevisíveis. Os previsíveis são aqueles que ocorrem de acordo com o desenvolvimento do núcleo familiar e em nossas relações dentro dos diferentes grupos nos quais estamos inseridos como, por exemplo, quando ocorrem nascimentos, no ingresso e egresso da escola, na união de duas famílias a partir de cerimônias de casamento e, sem dúvida, quando ocorrem falecimentos. Já os estressores imprevisíveis são aqueles que ocorrem de forma inesperada como, por exemplo, quando ocorre uma morte precoce ou um acidente. Perdas imprevisíveis, segundo Walsh e McGoldrick (1998), são as ocorrências que mais afetam a trajetória dos indivíduos ao longo de seu desenvolvimento, especialmente na relação com a família. 
... a perda pode ser vista como um processo transacional que envolve o morto e os sobreviventes em um ciclo de vida comum, que reconhece tanto a finalidade da morte como a continuidade da vida. Atingir o equilíbrio nesse processo é a tarefa mais difícil que uma família deve enfrentar em sua vida (p.27).

Ao analisarmos uma família enlutada, podemos afirmar que cada membro sentirá e reagirá à perda de um de seus integrantes de forma singular a partir de seu próprio repertório individual, mas internamente, todo o sistema é abalado e, ao luto particular soma-se o pesar do grupo por este todo que agora está sem uma de suas partes - vazio este que deve ser elaborado por todos conjuntamente. Desta forma, assim como deve ocorrer uma reelaboração individual do luto, a família também deverá se reorganizar e resignificar sua perda, de forma que os papéis possam ser validados e redistribuídos entre seus membros.

A morte de um ente da família produz uma alteração no sistema familiar como um todo. O choque e a dor de uma perda traumática perturba o equilíbrio familiar, gera uma redistribuição de papéis e, de modo mais grave, a dissolução da família (WALSH \& McGOLDRICK, 1998, p.43).

Ainda de acordo com as autoras, alguns fatores podem dificultar este processo de elaboração do luto na família, tais como o momento da morte no ciclo de vida familiar; o papel na família da pessoa que morreu; a existência de relações conflituosas ou rompidas na época da morte; as características da família (fraqueza no sistema familiar, nível de diferenciação de seus integrantes, sua comunicação e a existência de segredos); a história de perdas anteriores ou concomitantes; o tipo de morte; a reação da família no momento da morte; os legados multigeracionais de lutos mal elaborados; o sistema de crenças que podem evocar culpa e vergonha em torno da morte; a falta de recursos familiares, sociais e econômicos; e o contexto social e étnico da família.

A família pode, portanto, apresentar dificuldades na elaboração de seus lutos bem como comportamentos que deflagrem conflitos e rupturas do sistema, desorganização no realinhamento e redistribuição de papéis e pouco ou nenhum investimento em outras relações e projetos de vida, de forma a não permitir a reorganização da estrutura familiar e a promoção da identidade de seus membros. 
Nestes casos é possível falar em luto complicado, pois a família tende a vivenciar com rigidez seus relacionamentos, o que pode acarretar em uma desqualificação das reações de luto dos demais, negação da perda, falta de comunicação entre os membros do grupo, brigas, agressões e até mesmo casos de abuso de drogas (lícitas ou ilícitas), entre outros comportamentos de risco (WALSH \& MCGOLDRICK, 1998).

Como exemplo, podemos nos referir à morte de um filho para ilustrar a importância do falecido e o papel que este exerce na dinâmica familiar. A perda de um descendente é brutalmente devastadora e prematura pois, segundo Kovács (1992), a morte deve seguir uma sequencia "lógica" - primeiramente os pais e depois os filhos. Entendemos que a vida deva seguir seu curso natural de forma que todos vivam todas as fases do desenvolvimento e a morte deve ocorrer apenas na velhice, sendo qualquer outra forma de morrer considerada contra a natureza e, portanto, desnecessária e incompreensível (BELLATO \& CARVALHO, 2005).

O luto de um filho pode ser extremamente desestruturador para os genitores e, em qualquer idade (independente deste ser criança, adolescente ou adulto) é sentido como uma injustiça, pois rompe com esta suposta ordem natural da vida. Isso acontece porque, para os pais, os filhos sempre serão aqueles que devem viver mais, pois são eles que dão continuidade à família e são, na maioria das famílias, aqueles nos quais são depositados os sonhos e esperanças dos mais velhos. Quando um filho morre, os pais geralmente sentem-se fracassados, pois acreditam que sua principal tarefa era dar suporte e proteção ao descendente. Os amigos e familiares podem não saber como responder a perdas como esta que, em geral, são inesperadas, ficando assim impossibilitados de dar apoio à família enlutada neste momento tão difícil.

Outro fator importante relacionado à expressão do luto na família e na sociedade são as diferenças de gênero. Alguns autores (DOKA, 1996; GOLDEN, 1996) afirmam haver diferenças importantes entre os gêneros na vivência de luto e alertam que muitas das reações manifestadas por homens e mulheres (principalmente as reações masculinas) podem não ser identificadas como expressões de dor e pesar frente a uma perda. Devemos lembrar que a socialização de homens e mulheres é feita de maneira diferente, onde cada um aprende determinadas normas de gênero as quais deve seguir. 
É importante evidenciar que as diferenças entre homens e mulheres são biopsicossociais e culturais, e sofrerão variações de acordo com a classe social, raça e etnia, orientação sexual, entre outras variáveis que tornam homens e mulheres distintos entre si. Estas diferenças não devem ser entendidas como regras gerais, mas são fruto de nosso processo civilizatório e podem se perpetuar dentro dos sistemas familiares, levando a uma repetição de padrões de enlutamento entre os sexos através das gerações.

Não podemos dizer, por exemplo, que mulheres sentem mais a dor da perda do que os homens. Ambos sofrem e precisam elaborar seu luto, mas em geral diferem quanto ao modo de expressar seus pensamentos e sentimentos. Golden (1996) afirma que, em nossa sociedade, os homens são comumente criados de forma a não expressarem sentimentos e emoções como as mulheres - estas sim "autorizadas" a chorar, gritar e compartilhar com pessoas próximas (família, amigos, entre outros). Segundo o autor, homens se expressam menos publicamente do que as mulheres, o que pode dificultar o processo de elaboração do luto.

Quanto às reações de luto masculino, são características: ser mais quieto e menos visível; ser menos conectado com o passado e mais com o futuro; ser menos passivo e mais voltado para a ação; expressar mais naturalmente sua raiva do que outros sentimentos (e expressar mais raiva do que a mulher, que, geralmente, expressa mais tristeza e culpa); dar-se conta de outros sentimentos relacionados ao luto por meio da conexão com a raiva; ter maior necessidade de autonomia (o que o leva, muitas vezes, a um maior isolamento); entrar e sair do luto, buscando lugares e atividades que sirvam como válvulas de escape e dificuldade em ser cuidado (DOKA, 1996).

Outra característica do luto masculino, segundo Golden (1996), é que os homens restringem-se a expressar sentimentos de dor e sofrimento no período imediatamente após a perda, especialmente nos rituais como velório e enterro. Depois, tendem a buscar sozinhos as respostas as suas perguntas, não expressando mais abertamente seus sentimentos e pensamentos sobre o que aconteceu. De forma geral, os homens tendem a se expressar menos emocionalmente, porém, mais fisicamente através de atos, como por exemplo, retornando rapidamente ao trabalho e outras atividades laborais. 
Segundo Doka (1996), as mulheres têm mais facilidade em se expressar emocionalmente, aceitando ajuda de amigos e familiares. Os homens, segundo o autor, não recorreriam a outras pessoas pois isto seria um sinal de fraqueza, ou seja, que eles não conseguem resolver suas questões sozinhos, ou ainda: não querem ocupar outras pessoas com problemas que acreditam dizer respeito somente a eles. Além disso, expressar sentimentos como tristeza, culpa, amargura, entre outros, pode reforçar as ideia de fracasso e impotência. O choro, por exemplo, é uma expressão raramente masculina, pois muitos foram educados sob a premissa de que homens não choram. A repressão de sentimentos e pensamentos pode gerar ainda reações fisiológicas tais como insônia, mal-estar, fadiga e estresse (GOLDEN, 1996).

Devemos lembrar que sejam homens ou mulheres, cada membro da família reage à perda de um ente querido de forma diferente, mas não menos importante. Toda e qualquer expressão de dor e sofrimento deve ser validada para que o processo de elaboração dessa perda possa seguir seu curso normal, e esta validação ocorre justamente na presença dos pares que, juntos, formam uma importante rede de apoio.

Podemos fazer esta afirmação com segurança porque o indivíduo nunca está sozinho quando exposto a situações traumáticas e de perdas, já que se trata de um ser social, inserido em diversos grupos e sistemas. A família, em especial, deve ser percebida como uma unidade integral em constante mudança, que sofre diretamente o impacto do luto de um ou vários de seus membros. Na comunidade estão inseridas estas famílias e as demais organizações sociais que a compõem, todas atravessadas por uma história, uma cultura, um momento econômico e um ambiente social no qual uma tragédia pode se abater.

A resiliência, já referida anteriormente, também é um recurso que pode ser identificado em comunidades nos casos de perdas coletivas, e como nos apontam Klingman e Cohen (2004), refere-se à capacidade de seus membros em manter a esperança e a fé para suportar as perdas e traumas, superar as adversidades e deixar prevalecer a união do grupo. Segundo os autores, o apoio social e as ligações seguras entre os integrantes da comunidade diminuem significativamente o risco de sequelas da vivência traumática e aumentam os recursos de resiliência interna e externa de todos, individual e coletivamente. 
A comunidade geralmente tem reservas escondidas ou recursos que, quando compartilhados, oferecem apoio adicional e força aos indivíduos e às famílias. $\mathrm{O}$ apoio mútuo pode reduzir o impacto de grandes perdas, auxiliando as pessoas a apoiarem-se a si mesmas em seu processo de recuperação (KLINGMAN \& COHEN, 2004, p.65).

Hobfoll (1988 apud LANDAU \& SAUL, 2002), ainda sobre a questão da resiliência comunitária, desenvolveu a Teoria de Conservação dos Recursos, segundo a qual o autor afirma que as pessoas esforçam-se para obter, reter e proteger aquilo que valorizam. $\mathrm{O}$ estresse ocorre justamente quando as pessoas perdem seus recursos e ficam temerosas com relação as suas perdas, são incapazes de utilizá-los ou até mesmo melhorá-los, demandando assim um esforço ainda maior dos grupos atingidos. Quando ocorrem eventos extremamente estressantes, os sujeitos com menos recursos são mais profundamente impactados e, consequentemente, menos capazes de mobilizar a comunidade com um todo. Para uma melhor compreensão, é importante que nos aprofundemos na questão do luto patológico.

\title{
1.5 Meu eu sem você: o luto complicado
}

\author{
A imagem do objeto perdido, sua "sombra", cai \\ sobre o eu e encobre uma parte dele.
}

(NÁSIO, 1997)

Todo processo de luto é difícil e exige dos sujeitos um árduo e vagaroso trabalho de desvinculação. No processo de luto normal, sentimentos como tristeza, pesar, desamparo e saudade são esperados diante do rompimento do laço com o ente querido agora ausente, mas quando elaborados permitem que esta relação seja resignificada para que a energia investida no objeto possa ser realocada em novas trocas afetivas. Segundo Bowlby (2004), o que caracteriza um processo como luto patológico é justamente a exacerbação dos processos descritos nos casos de luto normal e uma duração mais longa. 
$\mathrm{O}$ autor afirma ainda que podemos diferenciar os processos normal e patológico do luto não só pela extensão do tempo em que persistem os sintomas, mas o quanto influenciam negativamente não só sobre o funcionamento mental, mas também emocional, laboral e familiar do individuo, podendo chegar a dominá-lo completamente. O grau de interferência dos sintomas e, consequentemente, o impacto que estes exercem sobre a dinâmica global do enlutado são fundamentais para a compreensão de seu estado físico e emocional.

Segundo Bolwby (2004), a depressão é um dos quadros mais frequentes e pode vir acompanhado muitas vezes de ansiedade (a essa combinação o autor chama de luto crônico). O anseio inconsciente pelo retorno da pessoa perdida, a censura inconsciente ao falecido relacionada a um sentimento de abandono e desamparo (que se apresenta muitas vezes, no nível consciente, através da autoacusação por não ter impedido a perda), o cuidado compulsivo com outras pessoas (seja por medo de perdê-las ou pelo desejo de substituir a pessoa que morreu), a descrença na irreversibilidade da perda (descrita como negação persistente) e o adiamento ou a inibição do luto são fatores que contribuem negativamente para o processo de elaboração da perda vivida.

Outra variação do luto patológico é quando a pessoa enlutada apresenta ausência prolongada de pesar consciente e a vida continua a ser organizada como antes. Neste caso, há uma crença (consciente ou inconsciente) de que a perda ainda é reversível e, enquanto o enlutado acreditar nisso, a elaboração do luto permanece incompleta. Podemos pensar também nos casos nos quais a dor não pode ser expressa, o que pode ocorrer por diferenças de gênero, múltiplas perdas (que demandam do sujeito uma pronta recuperação) ou mesmo como uma tentativa de aplacar o sofrimento de outros que lhe são caros. Em qualquer uma das hipóteses, o enlutado sofre a dor da perda, mas não pode processá-la, o que acarreta em um risco maior de embotamento e outros transtornos afetivos (BOLWBY, 2004).

Worden (1998) define o luto patológico como a intensificação do luto de forma que o enlutado sente-se desnorteado e pode apresentar comportamentos pouco adaptados, ou ainda permanece paralisado neste estado sem avançar no processo do luto. Desta forma, o sujeito não atinge os estágios de assimilação ou acomodação, ao contrário: fica preso às repetições ou até aos próprios obstáculos 
do processo de cura. Ainda segundo o autor, podemos traçar um perfil do luto complicado a partir dos quatro itens a seguir descritos:

1. Luto crônico: duração excessiva dos sintomas relacionados à perda e a impossibilidade de chegar a uma conclusão satisfatória;

2. Luto atrasado: a pessoa apresenta uma reação emocional insuficiente no momento da perda e, em um momento futuro, esta pode experimentar os sintomas do luto em relação a uma perda posterior e imediata com intensidade desproporcional e/ou excessiva;

3. Luto exagerado: respostas exageradas ou intensificação do luto normal. A pessoa enlutada sente-se abandonada e tende a apresentar condutas pouco adaptadas e/ou incapacitantes;

4. Luto mascarado: o enlutado não reconhece que seus sintomas e condutas estão relacionados à perda (podem aparecer encobertos, por exemplo, como sintomas físicos ou através de condutas bizarras).

Utilizando-se de nomenclaturas semelhantes, Parkes (1998) aponta que uma das características do luto patológico é sua cronicidade, ou seja, o prolongamento indefinido do luto com predomínio de ansiedade, tensão, inquietação e insônia. No luto crônico, há um prolongamento indefinido das reações de luto tanto quanto a duração como em intensidade. Outros indicadores de patologia, segundo o autor, são o luto adiado, no qual a pessoa enlutada demora a apresentar reações a perda vivida ou pode apresentar sintomas tais como superatividade, sintomas da doença do morto e isolamento. Outro quadro possível é o luto inibido, no qual os sintomas do luto normal estão ausentes e os enlutados não esboçam nenhuma reação ao longo do tempo.

Podemos inferir que, apesar das diferentes classificações, o luto patológico se caracteriza por uma exacerbação, distorção ou suprimento dos sintomas descritos no luto normal, impedindo que o enlutado possa desinvestir do objeto de amor de forma satisfatória. Em todas as variáveis, há prejuízos para a saúde física, mental, social e laboral dos enlutados (mesmo nos casos em que os indivíduos seguem com suas vidas como se nada houvesse ocorrido, pois esta realidade não perdura). Mas o que poderia desencadear este quadro de luto patológico? 
Diversos fatores interferem na elaboração do luto. Bowlby (2004) levanta cinco aspectos que podem dificultar este processo: (1) a identidade e o papel da pessoa que foi perdida; (2) a idade e o sexo do enlutado; (3) as causas e circunstâncias da perda; (4) as circunstâncias sociais e psicológicas que afetam o enlutado na época e após a perda; (5) a personalidade do enlutado, com especial referência a sua capacidade de amar e responder a situações estressantes. Franco (2005) também apresenta como fatores de risco:

... mortes repentinas, violentas, consideradas prematuras pelo enlutado; a causa da morte e seu significado; o tipo da morte, destacando-se exposição à mídia, mortes estigmatizadas ou causadoras de vergonha ao ambiente social; existência de segredos relativos à morte ou à sua causa; falta de rituais; falta de suporte; outras perdas concomitantes a morte (FRANCO, 2005, p.179).

O tipo de morte certamente pode dificultar a elaboração da perda, especialmente quando esta é inesperada e prematura ou após doença muito longa (como nos casos em que o enlutado ignorava o diagnóstico e/ou prognóstico do falecido). Há ainda situações nas quais o enlutado estava fisicamente distante por ocasião da morte, podendo sentir-se responsável ou culpado pela morte do ente querido, ou ainda casos de suicídio e mortes violentas tais como homicídios e latrocínios (WORDEN, 1998).

Outro fator complicador surge quando há perdas múltiplas, em que o sujeito se vê completamente arrebatado por uma séria de lutos simultâneos e/ou consecutivos, como podemos identificar nos casos de catástrofes, chacinas e acidentes. Estas perdas tendem a afetar diferentes esferas da vida dos sujeitos, causando uma ruptura maciça não só no plano individual mas também nos grupos sociais a que pertencemos (tema que será mais aprofundado no Capítulo 3).

Diversos autores adotam, em textos mais atuais, o termo luto complicado. Bromberg (2000) elenca alguns fatores que podem aumentar o risco de desenvolvimento de um processo de elaboração disfuncional, tais como quando o enlutado é jovem, tem baixa autoestima ou já viveu muitas perdas anteriores. Outros fatores que podem colocar em risco a saúde dos enlutados estão relacionados à relação que o indivíduo tinha com o falecido: se o morto era cônjuge ou um dos pais (especialmente nos casos de adolescentes que perdem um dos pais); enlutado ambivalente ou dependente na relação com o morto, ou perda 
de um ou mais filhos. A autora acrescenta ainda casos nos quais a elaboração da perda pode estar severamente comprometida por fatores mais específicos, podendo acarretar em quadros ainda mais preocupantes:

a) Síndrome da perda inesperada (morte repentina ou prematura): o enlutado apresenta reações defensivas como choque e descrença com alto grau de ansiedade. Nessa síndrome, as complicações são decorrentes da sensação persistente da presença do morto, autorrecriminação e sensação de contínuas obrigações para com o falecido;

b) Síndrome do luto ambivalente: ocorre quando a relação era marcada por discórdias ou descrença. No início, a perda é tida como alívio e há pouca ansiedade, mas com o decorrer do tempo, suscita desespero, sentimentos punitivos e o desejo de corrigir o passado.

Worden (1998) aponta também para a importância dos fatores sociais envolvidos no processo de elaboração de qualquer luto. Segundo o autor, as pessoas lidam melhor com suas perdas se tiverem em quem se apoiar e que se reforcem mutuamente. Diante desta nova realidade, necessitamos de espaços onde a dor e a tristeza diante da perda possam ser expressas e reconhecidas pelos demais - o que, em geral, ocorre durante os rituais - para que, a partir do reconhecimento e da concretização da perda possamos seguir o curso normal de enfrentamento.

Por conta da importância do outro neste processo de ventilação e validação da perda vivenciada, o autor cita três situações que podem contribuir para o desenvolvimento de um processo de luto complicado: 1) quando a perda não pode ser falada socialmente (como, por exemplo, nos casos de suicídio); 2) quando ocorre a negação social da perda (diante da qual as pessoas ao redor atuam como se a perda não houvesse ocorrido); e 3) quando não há rede de apoio (por exemplo, pessoas sem filhos ou familiares próximos ou família considerada inútil como fonte de suporte).

Podemos olhar esta questão também do ponto de vista histórico, já que a relação que o homem estabelece com a incontestável certeza de sua finitude e o processo de morrer sofreu importantes mudanças ao longo dos séculos, e estas mudanças implicam em novas formas e estratégias para lidar com o luto. 
$\mathrm{Na}$ cultura ocidental, cada vez mais o homem se distancia da morte, exigindo da sociedade reações mais contidas e rápidas em seu processo de enfrentamento das perdas, o que pode agravar ainda mais o estado emocional dos enlutados.

A exposição pública do sofrimento se vê mesclada, assim, por uma condenação velada do sofrer em público. A ambivalência predomina. No conjunto das relações pessoais a tendência é de uma reprovação tácita ao luto expresso publicamente, como se a dor causada pelo sofrimento pessoal de uma perda contaminasse os outros com a presença da morte (KOURY, 2011, p.29).

Homens e mulheres são cada dia mais cobrados a desempenhar papeis nos quais expressões duradouras de sofrimento e luto são rechaçadas e recriminadas, sob a justificativa de serem contraproducentes para a vida familiar e em sociedade. A divisão entre público e privado faz com que os indivíduos tornem-se cada vez mais reclusos e reprimam mais seus sentimentos de pesar, buscando por uma forma mais rápida e eficaz de elaborar suas perdas, de forma a solicitar menos o apoio dos demais membros da família e da comunidade.

Com relação a fatores circunstanciais que influenciam no processo de luto, Worden (1998) afirma que certas variáveis podem prejudicar o luto saudável como, por exemplo, nos casos nos quais a perda é incerta. Quando nos deparamos com situações como as de desaparecimento ou homicídio sem o resgate do corpo, o enlutado não tem certeza sobre o que aconteceu com a pessoa amada - se ela está viva ou morta - e pode não elaborar o luto de forma adequada.

Boss (1999), corroborando com esses apontamentos, acredita serem muitas as particularidades envolvidas neste tipo de perda, a qual chamou de perda ambígua. Segundo a autora, os enlutados devem conviver com a incerteza do paradeiro de seu ente querido e, em decorrência desta indefinição, sentimentos ambivalentes prevalecem, já que apesar de conviverem com a ausência física de seus amados, a esperança do reencontro se mantém acesa pois,

Não se pode dizer com segurança se o ser amado está vivo ou morto, recuperando-se ou morrendo, presente ou ausente. Não só falta informação sobre o paradeiro da pessoa, mas tampouco existe a constatação oficial da sociedade de uma perda: não há certidão de óbito (...) nem funeral, nem corpo, nem algo o que enterrar (BOSS, 1999, p.19). 
Boss (1999) afirma que pessoas que sofreram uma perda considerada ambígua têm maior risco de instalação de um processo de luto complicado pois sentem-se desorientadas e paralisadas, não sabendo como solucionar o problema, principalmente por não terem a confirmação se a perda é definitiva ou temporária. Essa incerteza impede que as pessoas se adaptem à ambiguidade da perda, reorganizando os papéis e as normas de sua relação com os entes queridos. A esperança de que o objeto perdido seja reencontrado pode impedir a elaboração da perda, pois esta não pôde ser confirmada pelo teste de realidade descrito por Freud (1917). Em geral, os enlutados “... necessitam da experiência concreta de ver o corpo do ente querido (...) porque isso faz com que a perda seja real" (BOSS, 1999, p.35).

Com relação ao suporte social, os rituais de passagem comuns nos casos de morte também são privados a essas pessoas. A sociedade não valida casos de perda ambígua como nos casos de luto por morte. A perda ambígua é muito distinta das perdas habituais como, por exemplo, nos casos de falecimento, nos quais, segundo a autora, os sentimentos de tristeza e pesar são validados durante os cerimoniais de funeral e de enterro ou cremação, assim como após a emissão do atestado de óbito e, mesmo após o fim dos ritos, restam a sepultura ou as cinzas da cremação como provas materiais e irrefutáveis do ato de despedida. Nestes casos, a perda é permanente e irreversível, mas é possível se enlutar e seguir em frente.

A comunidade, assim como a família, não chega a comprovar a perda em casos de desaparecimento e, assim como os parentes do ausente, sentem-se impotentes e desorientados, impossibilitados de validar a mesma. Em decorrência disto, é frequente que as pessoas se afastem dos que permanecem a espera do desaparecido em lugar de fornecerem o apoio que ofereceriam no caso de uma perda por morte devido ao prolongado tempo do enlutamento e a incerteza diária da perda, já que

As perdas dos outros nos remetem às nossas próprias vulnerabilidades e isso pode causar ansiedade (...) os amigos e vizinhos podem sentir-se sobrecarregados porque o grau de ajuda que se necessita é consideravelmente alto para que se possa mantê-lo quando a perda ambígua é prolongada (BOSS, 1999, p.81). 
Em todos estes casos, não devemos esquecer que o processo de luto é individual, único e cada sujeito se expressará de forma diferente dos demais. Ao definirmos o luto só pretendemos “... permitir a descrição e compreensão da experiência da perda, quanto ao funcionamento psíquico e relacional do enlutado, para permitir o delineamento da intervenção mais adequada" (BROMBERG, 2000, p.42).

Nossa pesquisa tem como principal objetivo refletir justamente sobre a experiência humana diante de múltiplas perdas, dentre elas a perda de entes queridos que desapareceram após um desastre. Nosso mundo (presumidamente) seguro se vê completamente abalado quando somos expostos a situações de perdas - especialmente se estas são traumáticas - e temos que dispor de todos os recursos para lidar com a alta complexidade deste tipo de luto (PARKES, 2009).

Diante de tantas variáveis que podem comprometer o processo de elaboração do luto - mortes incertas, falta de corpos e ausência ou distorção dos rituais, perdas não reconhecidas e simbólicas - como enfrentar o turbilhão de acontecimentos quando eles ocorrem simultaneamente? E se, entre essas perdas, há o desaparecimento de um ente querido? E se também se é sobrevivente onde muitos padeceram? Para compreendermos esse fenômeno, devemos antes conhecer um pouco mais sobre a realidade da qual estamos falando: o que é um desastre? Como podemos definir este conjunto de eventos que rompem com a vida de milhares de pessoas todos os anos ao redor do mundo? 


\section{PERDAS MÚLTIPLAS E DESASTRES: INEVITÁVEL COMBINAÇÃO?}

Nós sabemos, racionalmente, que desastres acontecem, mas se nossa experiência nos ensina que eles acontecem às outras pessoas e não acontecem comigo, então vamos adotar essa suposição básica e nos sentir seguros. Quando um desastre nos atinge, qualquer que seja a causa, nossa concepção básica de que o mundo é um lugar seguro é abalada e, muito rapidamente, ele se torna inseguro.

(PARKES, 2009)

No capítulo anterior, tratamos sobre a questão do luto frente às diversas perdas vividas ao longo de nosso ciclo vital, sejam elas esperadas (como as mudanças corporais do processo de envelhecimento, nascimentos, casamentos e falecimentos no núcleo familiar, dentre outras), ou as que se dão de forma abrupta, como nos casos de perda inesperada (suicídio, homicídio, desaparecimentos, dentre outras). Toda e qualquer perda exige do indivíduo um processo de elaboração cuja duração é variável, e este pode ser concluído de forma gradual e satisfatória ou, em alguns casos, pode ocorrer de forma disfuncional, acarretando em prejuízos nas áreas afetiva, laboral, familiar e social (PARKES, 2009).

Assim sendo, todo processo de luto é complexo e exige do indivíduo um trabalho de elaboração e resignificação da relação estabelecida com o que ou quem se perdeu, de forma que a libido investida no objeto de amor, agora ausente, possa ser realocada de forma saudável. No entanto, em casos de perdas abruptas e inesperadas, a capacidade do sujeito em lidar com seu luto pode ficar comprometida frente a outras variáveis envolvidas, tais como a forma como se deu a perda, a culpa por acreditar que poderia tê-la evitado ou mesmo por ter sobrevivido a um evento em que muitos padeceram (FRANCO, 2005).

Aqui nos aproximamos de nosso estudo em questão. Como processar perdas vividas em um contexto de desastre? É possível mensurar o que foi perdido em um cenário onde caos e destruição são não só a realidade de um, mas de 
centenas de pessoas? Como lidar com perdas humanas, materiais, sociais e de valor sentimental, todas decorrentes de um mesmo evento? Para dar início a esta reflexão, faz-se necessário antes apresentar alguns conceitos que serão utilizados ao longo do trabalho e que implicam diretamente na compreensão que temos sobre o fenômeno a ser estudado: a vivência de perdas múltiplas. O que é, afinal, um desastre?

Neste capítulo, apresentaremos as principais definições relacionadas aos desastres, tais como suas classificações e os aspectos que determinam o impacto destes eventos nas comunidades afetadas. Estas informações são de extrema relevância especialmente em decorrência do número crescente de catástrofes não só no Brasil, mas também ao redor do mundo o que, consequentemente, aumenta exponencialmente o número de pessoas afetadas anualmente por este tipo de ocorrência. Também serão apresentados dados relativos ao desastre ao qual nos referimos em nosso estudo - as chuvas ocorridas na Região Serrana do Rio de Janeiro no início do ano de 2011 - a fim de contextualizar a realidade na qual esta pesquisa foi realizada.

\subsection{Um olhar sobre a questão dos desastres}

O que mais amedronta é a ubiquidade dos medos; eles podem vazar de qualquer canto ou fresta de nossos lares e de nosso planeta (...) do que chamamos 'natureza' (pronta, como dificilmente antes em nossa memória, a devastar nossos lares e empregos $e$ ameaçando destruir nossos corpos com a proliferação de terremotos, inundações, furacões, deslizamentos, secas e ondas de calor).

(BAUMAN, 2008)

Desde os tempos mais remotos, podemos encontrar registros das chamadas catástrofes, sejam elas naturais - como a erupção do Monte Vesúvio, em 79 d.C; a Peste Negra, de 1330 a 1351; ou o grande terremoto da China, em 1556 - até as chamadas catástrofes humanas - como Hiroshima, em 1945; Chernobyl, em 1986; e o atentado as Torres Gêmeas em 2001. 
Apesar de serem eventos de diferentes origens e em momentos distintos de nossa História, todos possuem uma triste semelhança: centenas, milhares e até mesmo milhões de pessoas padeceram e tantas outras tiveram gravadas em suas histórias a marca dessas catástrofes. As repercussões dessas tragédias transcendem gerações deixando rastros de medo, desamparo, terror e sofrimento que perduram em nosso imaginário através da História.

Segundo SPIGNESI (2005), catástrofes são eventos de grande magnitude por sua área de impacto e pelo número de pessoas afetadas, as quais trazem grandes repercussões ambientais, sociais, financeiras e, principalmente, no contingente humano envolvido. Segundo as definições atuais, catástrofes e desastres podem ser considerados sinônimos na literatura sobre o tema. Mas quais os critérios de classificação destes eventos? O que de fato caracteriza um fenômeno como um desastre?

Para estabelecer a ordem dos eventos que estão diretamente relacionados aos desastres, é possível dizer que todo evento de ampla magnitude inicia-se pelo quadro denominado como situação de emergência, que consiste no “... reconhecimento legal pelo poder público de situação anormal, provocada por desastres, causando danos (superáveis) à comunidade afetada" (GOVERNO DO ESTADO DO RIO DE JANEIRO, 2006, p. 200). Quando os recursos se esgotam ou os danos passam a ser considerados insuperáveis, o fenômeno em questão passa a ser considerado como calamidade pública, ou seja, “... é o reconhecimento legal pelo poder público de situação anormal, provocada por desastres, causando sérios danos à comunidade afetada, inclusive à incolumidade e à vida de seus integrantes" (GOVERNO DO ESTADO DO RIO DE JANEIRO, 2006, p. 196).

No decorrer do fenômeno calamitoso, se recursos, danos e gerenciamento tornam-se escassos e rapidamente insuficientes, atinge-se o quadro denominado catástrofe ou desastre propriamente dito. Segundo o Manual de Desastres Naturais, documento elaborado pela Secretaria Nacional de Defesa Civil, desastres são “... resultado de eventos adversos, naturais ou provocados pelo homem, sobre um ecossistema vulnerável, causando danos humanos, materiais e ambientais e consequentes prejuízos econômicos e sociais” (CASTRO, 2003, p.04). 
Em outras palavras, desastres são eventos traumáticos que causam a ruptura das estruturas até então estáveis da sociedade, podendo levar a população afetada a níveis preocupantes de estresse (agudo e/ou pós-traumático). Entende-se que, tanto do ponto de vista geográfico/geológico como do ponto de vista sociológico, a extensão dos danos - em especial, os danos humanos - é apontada como o fator mais importante para a avaliação das condutas posteriores e de prevenção a futuros acontecimento de natureza semelhante.

Ainda segundo a Secretaria Nacional de Defesa Civil (BRASIL, 2012), para que haja o reconhecimento federal da catástrofe, o desastre deve causar grave perturbação ao funcionamento de uma comunidade ou sociedade, envolvendo extensivas perdas e danos humanos, materiais, econômicos ou ambientais, que excedem a sua capacidade de lidar com o problema usando meios próprios. Para a declaração oficial sobre o grau de extensão da emergência, são exigidos dados mensuráveis e objetivos por parte dos profissionais envolvidos. Estes dados relacionados à ocorrência de desastres são registrados através de documentos oficiais, como os formulários de Avaliação de Danos (AVADAN - atualmente extintos) e de Notificação Preliminar de Desastre (NOPRED), bem como Decretos de Declaração de Estado de Calamidade Pública (ECP) ou de Situação de Emergência (SE) e Portarias de Reconhecimento Federal, além de informes prestados pelas Coordenadorias Estaduais de Defesa Civil (CEDECs).

Segundo Ocampo (2006), desastres são eventos extraordinários, que originam destruições consideráveis de bens materiais e podem ter como resultado mortes, lesões físicas e sofrimento humano. Esses fenômenos podem ser lentos ou repentinos e determinados por fatores naturais (como enchentes, inundações, terremotos, furacões) ou produzidos pelo próprio homem (como as guerras, o terrorismo, incêndios, contaminação química ou nuclear e vandalismo social considerados, pelo especialista, como uma nova forma de desastre).

Já a Organização Pan-Americana de Saúde (OPAS), de acordo com informações emitidas pela Organização Mundial de Saúde (OMS, 2009), define desastre (ou emergência) como um fenômeno natural ou causado pela ação humana que resulta num distúrbio massivo no sistema dos serviços de saúde, refletindo numa imediata ameaça à saúde pública, o que ocasionaria a localidade afetada a necessidade de assistência externa para enfrentar à situação. 
Pesquisas relacionando desastres e saúde mental são relativamente recentes, de acordo com Ocampo (2006), começando pelo desastre no cais do porto da cidade de Halifax (EUA), em 1920, quando S. H. Prince investigou, pela primeira vez, as variáveis psicológicas após a ocorrência de uma catástrofe. Em 1944, foram realizados estudos com sobreviventes do incêndio no clube noturno Coconut Grove, em Boston; já em 1963, foram entrevistados os atingidos pelo terremoto de Skoplje, na Iugoslávia e, quatro anos depois, em 1967, estudos foram conduzidos para avaliar as intercorrências com as vítimas do holocausto nuclear de Hiroshima.

Somente em 1974 foi criada a Lei de Atuação e Ajuda em Desastres através do Instituto de Saúde Mental do Departamento de Saúde dos Estados Unidos, na qual estabeleceu-se a criação de uma seção de Orientação Psicológica para sobreviventes de desastres (OCAMPO, 2006). A partir da elaboração da lei, foi criado o Centro de Informações sobre Desastres (CRID) pela Organização Pan-americana de Saúde e os profissionais envolvidos passaram a buscar novas e melhores técnicas para atender as demandas emocionais dos sobreviventes de desastres (tendo como referência de primeira atuação os atendimentos realizados em 1976, durante as inundações em Buffalo Creek).

No Brasil, a preocupação com desastres tem aumentado na proporção em que também crescem o número de novas ocorrências no país. O Governo Federal conta com o Centro Nacional de Gerenciamento de Riscos e Desastres que está sob a coordenação técnica do Departamento de Resposta aos Desastres e Reconstrução, cujo objetivo é gerenciar ações preventivas e de reação, assim como mobilizar recursos humanos e materiais para evitar ou reduzir os danos causados pelas intempéries.

Mas o Brasil ainda carece de desenvolvimento e maior investimento nesta área. Podemos destacar que apenas em setembro de 2004 foi criado o Comitê Gestor Nacional da Atenção às Urgências, cuja missão é assessorar governos e instituições envolvidas diretamente na estruturação e organização da atenção às urgências no país, além de fornecer suporte à atuação do Serviço de Atendimento Móvel de Urgência (SAMU) e elaborar o Plano de Atenção a Desastres (trabalho até então desenvolvido, exclusivamente, pela Política Nacional de Defesa Civil). 
O desenvolvimento tardio de políticas públicas de prevenção a desastres é preocupante, já que nosso país possui diversos registros de intempéries ao longo da História. As características de nosso relevo, solo e clima são amplamente conhecidas pelos governantes e a ocupação maciça dos grandes centros urbanos também já é um fato inegável em nossa sociedade, o que nos faz pensar que a escassez de estratégias e recursos pode denunciar um certo descaso com a população já tão vulnerável e despreparada. Mas como determinar se uma ocorrência é, de fato, um desastre?

As catástrofes são classificadas por sua origem, intensidade e evolução. É importante ressaltar que, para um evento ser classificado como desastre ou catástrofe, essas três esferas devem ser avaliadas tanto em relação à quantidade de danos e prejuízos como à qualidade dos recursos disponíveis após o evento em questão. Dependendo da amplitude do evento e da escassez de estratégias e materiais disponíveis, poderá ser considerado apenas como "estado de calamidade pública" (como dissemos anteriormente, esta situação requer apoio de outras entidades externas à comunidade atingida, mas seus impactos são considerados manejáveis).

Para compreendermos melhor o fenômeno dos desastres, vejamos as classificações descritas pelo Manual de Desastres Naturais (CASTRO, 2003), segundo as quais o Brasil se orienta para a criação de políticas públicas de prevenção e redução de danos em casos de catástrofe:

\section{a. Origem dos desastres}

- Naturais: desastres resultantes de desequilíbrios da natureza, cujos fatores são de origem externa e sua ocorrência independe da ação dos homens. Dentre os desastres naturais, destacam-se: a) os de origem sideral, como o impacto dos meteoritos (ex: extinção dos dinossauros); b) os eventos relacionados à geodinâmica terrestre externa ou a fenômenos meteorológicos (chuvas, vendavais, maremotos, inundações); c) os eventos relacionados à geodinâmica terrestre interna ou fenômenos tectônicos (terremotos, tsunamis, erupções vulcânicas); d) ocorrências de desequilíbrio da biocenose (comunidade de seres vivos de uma determinada região), tais como pragas animais ou vegetais. 
- Humanos ou antropogênicos: resultado de ações (ou omissões) humanas; o homem tem implicação direta na ocorrência do desastre, os quais podem ser classificados: a) de natureza tecnológica, consequência do desenvolvimento desordenado das cidades, ou seja: quando o incremento demográfico e o desenvolvimento da infraestrutura e dos serviços não seguem a mesma evolução e tem uma preocupação maior com o retorno imediato do investimento em detrimento da segurança da cidade em si. Podemos referir os acidentes envolvendo meios de transporte, incêndios, vazamentos de produtos perigosos, etc; b) de natureza social, consequência do mau relacionamento do homem com o ecossistema e consequente desequilíbrio econômico, político e cultural. Podemos citar os diversos tipos de violência, os altos índices de desemprego, criminalidade, fome e desnutrição, além do tráfico de drogas; etc) de natureza biológica, consequência da pobreza e baixa eficiência dos serviços responsáveis pela promoção de saúde publica (podemos referir as pandemias de AIDS, tuberculose e dengue).

- Mistos: resultantes da interação entre os fenômenos naturais e a ação humana. Essa junção de fatores, em geral, leva a maiores e mais devastadores impactos à população atingida. Estão relacionados à geodinâmica terrestre externa (tais como chuvas ácidas, efeito estufa, buracos na camada de ozônio) ou à geodinâmica terrestre interna (desertificação, degelo nos Pólos Norte e Sul, desbarrancamentos em áreas de risco por ocupação ilegal ou desordenada ou obras sem planejamento estrutural).

\section{b. Intensidade dos desastres}

- Nível I - desastre de pequeno porte (também chamado de acidente): os danos são considerados pequenos e de fácil recuperação e o reestabelecimento da ordem se dá de forma mais rápida e menos traumática à população atingida;

- Nível II - desastres de médio porte: danos significativos, mas com bom prognóstico de superação pela população atingida; 
- Nível III - desastres de grande porte: acarretam em danos e prejuízos significativos, mas ainda assim são passíveis de resolução se a comunidade afetada estiver bem informada, preparada e puder participar ativamente do processo de reconstrução. Nestes casos, a Defesa Civil e os órgãos estaduais podem (e devem) auxiliar a população;

- Nível IV - desastres de porte muito grande: nestes casos, mesmo que a população esteja informada, preparada e mobilizada, não é possível dar conta de todas as perdas envolvidas, já que os danos e prejuízos atravessam as esferas individuais, sociais, econômicas e, em geral, levam a dificuldades de acesso à saúde, alimentação, vestuário. Em desastres nível IV, é imprescindível a atuação da Defesa Civil e dos demais colaboradores públicos ou privados.

\section{c. Evolução dos desastres:}

- Desastre súbito ou de evolução aguda: marcado pela frequente imprevisibilidade, velocidade da ocorrência e violência dos danos e prejuízos. Muito comum em eventos cíclicos e sazonais como, por exemplo, terremotos, chuvas, deslizamentos de solo e erupções vulcânicas;

- Desastre gradual ou de evolução crônica: marcado pela evolução mais lenta e agravamento progressivo dos danos e prejuízos como, por exemplo, cidades abatidas pela seca e os fenômenos de desertificação e degelo;

- Desastre por somação de efeitos parciais: marcado pela repetição de acidentes e ocorrências aparentemente de pequeno porte mas que, quando somados, levam à constatação de um desastre, tais como o alto número de acidentes de trânsito, incidentes no ambiente de trabalho, o aumento ainda substancial de casos de AIDS, entre outros.

Pesquisas mais recentes afirmam que este tipo de classificação é tendenciosa e defasada, podendo incorrer em erros quando pensamos em programas de prevenção e promoção de saúde junto a população e ainda mais perigos quando falamos em redução de riscos a novos desastres. Isto porque os desastres são, em geral, multifacetados e não podem ser avaliados a partir de um único ponto de origem. 
Marandola Jr. e Hogan (2005) enfatizam que um desastre deve ser compreendido sempre como um fenômeno decorrente da interação homemambiente já que um não pode ocorrer sem a interferência do outro. Os autores classificam os desastres como environmental hazards (relacionados ao meio ambiente físico e biótico); technological hazards (relacionados às estruturas, processos e produtos tecnológicos); e social hazards (resultantes do comportamento humano), mas alertam para o fato de que um tipo de desastre pode levar a outro pois estes se relacionam e se intercruzam - como exemplo, os hazards tecnológicos e sociais podem incidir sobre o meio, causando o que os autores chamam de hazard quasi-naturais.

Diante de situações catastróficas, como reagir? Diversos autores têm se dedicado ao estudo deste fenômeno, tendo em vista não só o grande número de pessoas anualmente atingidas por essas intempéries, mas principalmente por ser uma situação muito particular, a qual envolve não apenas uma, mas diversas perdas concomitantes, e os profissionais envolvidos no atendimento aos sobreviventes devem estar cientes da complexidade do evento com o qual estão lidando, assim como adequar as técnicas ao momento em que este suporte é prestado (pré, durante ou após o desastre).

Segundo Castro (2003), os desastres possuem três fases: a) o pré-impacto, a qual precede o desastre (fase de ameaça, advertência ou alerta); b) a fase de impacto propriamente dito, que consiste no momento em que os indivíduos são atingidos pelo fenômeno; e c) o pós-impacto, composto pelos diferentes momentos que sucedem o desastre (mas sempre com vistas à reconstrução). Em todas as suas fases, os desastres são eventos altamente desruptivos e, segundo o autor, levam caos e desorganização aos locais e pessoas atingidos.

As características da fase pré-impacto são de extrema importância para compreendermos algumas possíveis respostas nas etapas que se sucedem, tais como o nível de integração e os conflitos existentes na comunidade durante os períodos de normalidade e a experiência adquirida em eventos anteriores (desastres prévios). Desta forma, o desastre e suas repercussões devem ser considerados como a interface entre a população e o ambiente, ou melhor, entre o fenômeno natural e a organização social. 
$\mathrm{Na}$ fase do desastre propriamente dito, o nível de desorganização, medo e confusão é mais acentuado, segundo Ocampo (2006). Para o autor, podemos identificar três fases principais durante a ocorrência da situação catastrófica:

- $1^{\text {a }}$ fase: estado de choque, aturdimento, estupor, apatia, confusão, insensibilidade com o fenômeno;

- $2^{\text {a }}$ fase: estado de ambivalência que pode durar horas ou até mesmo dias.

Os atingidos são mais dóceis ao receberem ajuda e mais angustiados quando estão desprotegidos;

- $3^{\text {a }}$ fase: euforia por estar vivo, intenso espírito de solidariedade, colaboração versus atos de delito, depressão.

Já Ripley (2008) afirma que, no caso de sermos atingidos por um desastre seja ele natural, humano ou misto - nossos instintos respondem ao que a autora chama de arco de sobrevivência. De acordo com esse modelo de respostas, todos os sujeitos expostos a eventos traumáticos serão impactados, mas ao longo da vida, alguns indivíduos desenvolvem maiores e melhores habilidades de enfrentamento diante de situações de estresse. Segundo a autora, as pessoas possuem três formas básicas de reação frente a catástrofes:

- Paralisação total: congelamento motor e cognitivo diante do qual o indivíduo não consegue responder ativamente aos estímulos a sua volta. Nesses casos, a pessoa corre sério risco de sofrer ferimentos graves ou mesmo de morrer, pois sua percepção do perigo é menor do que sua incapacidade de reagir;

- Luta/esquiva: o indivíduo reage instintivamente ao perigo, mas sua capacidade de se organizar é limitada e o sucesso de suas ações depende de fatores como exposição anterior a eventos catastróficos, habilidade de tomar decisões, pronta resposta e organização cognitiva. Caso a pessoa possua essas habilidades, a chance de sair ilesa do desastre é muito maior, mas seu comportamento pode também deflagrar uma total falta de preparo quando o sujeito age de forma quase primitiva e apenas foge da situação, sem necessariamente pensar sobre as estratégias que está adotando para se salvar; 
- Atitude heroica: o indivíduo, ao ser exposto a uma situação de desastre, tende a responder motivado pelo bem estar do próximo, mesmo que este comportamento implique em um maior risco a sua própria segurança. Essa resposta é considerada pouco adaptativa, pois, em geral, homens e mulheres não possuem treinamento ou preparação específica para lidar com situações extremas (como são comumente os cenários de desastre).

A OMS (2009) também atenta para o fato de que, em todas as situações de desastre, diversas pessoas são atingidas, e dentre estas, algumas já possuem vivências prévias semelhantes. De acordo com a organização, os desastres, para elas, podem ser entendidos como eventos habituais - como nos casos de quem vive em países onde essas ocorrências são frequentes (por exemplo, no Japão) - e as reações de medo podem ser menores. No entanto, de maneira geral, a primeira reação, ainda assim, é de fuga/esquiva, pois mesmo em locais onde ocorrências deste tipo são mais frequentes, as pessoas geralmente estão desavisadas e despreparadas diante de toda destruição própria às catástrofes.

Diante de um desastre, além de reações de fuga/esquiva, podemos elencar uma série de outros comportamentos possíveis frente ao caos inerente a este tipo de acontecimento, mas não o suficiente a ponto de abarcar todas as respostas individuais, pois cada pessoa possui diferentes recursos de enfrentamento, como nos aponta Marchezini (2010):

Em meio ao caos coletivo, vemos que as respostas individuais fazem toda a diferença - para o melhor e para o pior. Quando não existe uma ordem externa, institucionalizada, as pessoas dependem exclusivamente do seu sistema de referências interno. É ele que dá sustentação e orienta a conduta individual, com efeitos importantes no nível coletivo. Por isso vemos que, mesmo num evento de grandes proporções, as pessoas são atingidas com graus de intensidade variados e apresentam respostas e capacidade de reconstrução diferenciadas (p.1).

Há ainda que lembrar que, nestes contextos, há sempre indivíduos que requerem especial cuidado como, por exemplo, pessoas com enfermidades mentais (diante das quais não temos como prever as reações), portadores de necessidades especiais ou pessoas que sofrem de alguma enfermidade física (as quais demandam atenção diferenciada por suas debilidades), além de idosos e 
crianças, os quais possuem uma forma particular de lidar com os estressores (OCAMPO, 2006). Há ainda os animais de estimação (como gatos, cachorros, aves, coelhos, tartarugas, entre outros) que, para muitos, são considerados parte da família, e podem não ter condições de, sozinhos, escapar do fenômeno catastrófico, exigindo que seus donos ou outros sobreviventes tentem socorrê-los.

Castro (2003) aponta que, em situações de desastre, devemos nos atentar também para alguns fatores de risco para a saúde mental, tais como o número de mortos; a dimensão da destruição e intensidade da catástrofe; a centralidade da comunidade atingida; a duração; a rapidez com que se iniciou o agente causador da intempérie; o grau de previsibilidade e periodicidade do fenômeno. Além destas variáveis, há também a dificuldade de acesso aos locais atingidos, limitações de idade de alguns moradores da comunidade e a falta de conhecimento em técnicas de resgate e transporte de feridos.

Diversos estudos citados por Krum (2007) indicam que situações de desastre podem desencadear sintomas que podem acarretar em prejuízos graves a saúde mental e à convivência social dos sobreviventes, tais como tristeza, distúrbios de sono e apetite, ansiedade, isolamento, preocupações com morte e perdas (de si e de outrem), e posteriormente, quadros de Transtorno de Estresse Pós-traumático (TEPT).

No entanto, não podemos esquecer que as pessoas afetadas por um desastre precisam de tempo para assimilar não só a devastação externa a si, mas também a desorganização interna causada pela catástrofe em suas vidas. Isso se dá especialmente porque quaisquer acontecimentos que provoquem mudanças intensas em nossas vidas - especialmente quando são eventos totalmente inesperados - desafiam o que acreditamos ser nosso mundo presumido, levando a uma crise, e os indivíduos podem parecer inquietos, tensos, ansiosos e até mesmo indecisos até que a readaptação seja concluída (PARKES, 2009).

Se a destruição e o caos permanecem presentes nas vidas dos sobreviventes mesmo após o fim do evento catastrófico, os processos de reorganização e resignificação individual e coletiva ficam comprometidos, e por isso devemos tomar cuidado para não patologizarmos algo que está diretamente relacionado à premente necessidade de seguir em frente a partir do investimento na reconstrução dos locais atingidos. 
Sob esta ótica, podemos afirmar que o grau de desorganização não está relacionado apenas ao impacto do desastre em si, mas também as concepções de risco e vulnerabilidade do mundo que nos cerca. Estamos (cons)cientes destes perigos? Como enfrentamos os medos e anseios em um contexto onde pouco se fala sobre prevenção? No Brasil, o quanto exigimos de nossos direitos e o quanto cumprimos com nossos deveres como cidadãos?

\title{
$2.2 \quad$ Risco e vulnerabilidade
}

\begin{abstract}
Só é possível nos preocuparmos com as consequências que podemos prever, e é só delas que podemos lutar para escapar. E assim, só as consequências indesejadas desse tipo "pré-visivel" é que classificamos na categoria de "riscos". Esses são perigos de cuja probabilidade podemos (ou acreditamos poder) calcular: riscos são perigos calculáveis.
\end{abstract}

(BAUMAN, 2008)

Nas últimas décadas, o aumento no número de ocorrências que evoluem de forma danosa à população tornou-se preocupante principalmente porque estas, em sua maioria, atingem a triste marca de desastres. Como já referimos anteriormente, desastres naturais, humanos e mistos datam de milhares de anos, mas com o advento de novas tecnologias, o aumento populacional e a utilização pouco consciente de nossos recursos naturais, esse processo tem acelerado - e muito - a degradação da natureza.

No Brasil, os dados são alarmantes e tem como principal resultado uma maior incidência de catástrofes relacionadas a eventos geodinâmicos e pluviométricos (BRASIL, 2012). Cada região do país possui características distintas em relação ao relevo, solo e clima e enfrenta, nas quatro estações do ano, as dificuldades relacionadas, principalmente, as mudanças de temperatura e suas consequências (como seca e chuvas). Como nosso país tem buscado enfrentar esta realidade tão assustadora e implacável? O Brasil, através do Ministério de Integração Nacional e da Secretaria Nacional de Defesa Civil, fornece recursos e estratégias eficazes para o enfrentamento de intempéries? Estamos seguros? 
Em 2003, o Ministério da Integração Social disponibilizou o Volume I do Manual de Desastres Naturais (CASTRO, 2003), elaborado com base na Classificação Geral dos Desastres e na Codificação de Desastres, Ameaças e Riscos (CODAR). Este manual tem como objetivo principal auxiliar os profissionais interessados a prestar o melhor apoio possível à população nas três fases de um desastre - pré, durante e após a sua ocorrência. Neste documento (ainda considerado referência para os estudiosos sobre o tema), o autor sistematiza e classifica os desastres de acordo com suas características, possíveis causas, ocorrência e incidência. O manual se propõe a identificar os principais efeitos adversos, a capacidade dos órgãos envolvidos nas tarefas de monitoração, alerta e alarme, assim como sugerir melhorias relacionadas às medidas preventivas futuras.

Segundo pesquisa realizada pelo Centro Universitário de Estudos e Pesquisas sobre Desastres da Universidade Federal de Santa Catarina (CEPEDUFSC, 2011), os desastres naturais mais recorrentes no Brasil são as estiagens e secas, que correspondem a 54\% das ocorrências; seguida das inundações bruscas e alagamentos com $21 \%$, e inundações graduais com $12 \%$ do total de desastres registrados entre 1991-2010.

Mais recentemente, em 2011, a Secretaria Nacional de Defesa Civil publicou através do Centro Nacional de Gerenciamento de Riscos e Desastres (CENAD) o $1^{o}$ Anuário Brasileiro de Desastres Naturais, uma publicação que reúne informações importantes sobre desastres naturais do país referentes ao ano de 2010. Além de dados sobre as catástrofes ocorridas durante o ano descrito, a publicação ainda apresenta informações sobre as características do relevo, vegetação, incidência de eventos geodinâmicos e pluviométricos e índices de temperatura e pressão atmosféricas relevantes para compreensão do clima das cinco regiões do Brasil.

Em 2012, o $2^{\circ}$ Anuário Brasileiro de Desastres Naturais foi aperfeiçoado e, nesta edição, podemos encontrar informações sobre a caracterização geográfica das regiões brasileiras, clima e vegetação específicos e o perfil dos desastres mais frequentes em cada estado (desde seca até inundações e vendavais). Os dados são alarmantes: 
No ano de 2011, os desastres naturais, mais uma vez, tiveram um impacto significativo na sociedade brasileira. No Brasil, oficialmente foi relatada a ocorrência de 795 desastres naturais, os quais causaram 1.094 óbitos e afetaram 12.535.401 pessoas. Quanto aos municípios, 2.370 foram afetados, sendo que $65,44 \%$ deles por eventos hidrológicos (BRASIL, 2012, p.31).

O número de registros oficiais de desastres relacionados a inundações e precipitações bruscas em todo o Rio de Janeiro entre os anos de 1991 a 2010 chegou a 262 casos (CEPED-UFS, 2011). Em 2011, no entanto, apesar de não representarem a maior incidência estatística do estado, foram os eventos pluviométricos que trouxeram os maiores prejuízos humanos e materiais a população - alavancado, principalmente, pelas chuvas ocorridas na Região Serrana do Rio de Janeiro.

Como vemos, o tema dos desastres é bastante abrangente e complexo e o número de pessoas atingidas é assustador. Em nosso estudo, trabalharemos especificamente com o fenômeno das chuvas e suas mazelas, tendo em vista que devemos reconhecer os eventos pluviométricos não apenas pela ocorrência de tempestades episódicas, mas sim como um conjunto de ocorrências mistas, como descritas a seguir:

Os desastres de chuvas intensas estão associados a grandes volumes acumulados de precipitação. Esses eventos são muitas vezes deflagradores de outros tipos de desastres, sejam eles hidrológicos (enxurradas, inundações graduais ou bruscas e alagamentos), ou geológicos (movimentos de massa e erosão), e ocorrem muitas vezes associados com outros desastres meteorológicos (granizo, vendaval e tornados) (BRASIL, 2012, p.55).

Desta forma, os eventos ocorridos na Região Serrana, foco de nosso estudo em questão, não podem ser compreendidos apenas pelo intenso volume de água durante as tempestades, mas principalmente como uma sucessão de desastres que se abateram sobre as localidades - em especial as cidades de Petrópolis, Teresópolis, Nova Friburgo, São José do Vale do Rio Preto e Sumidouro, além dos municípios de Itaipava, Areal e Bom Jardim - de forma implacável e arrebatadora, deflagrando o que já alertavam Valencio et al. (2005): 
... o que ocorre com a chegada de uma frente fria é mais do que uma precipitação pluviométrica. Em áreas baixas das zonas urbanas, são os problemas de drenagem, os quais ocasionam as enchentes e inundações, com transbordamento de esgoto a invadir os domicílios. Nas áreas altas, a ocupação em terrenos geomorfologicamente instáveis propicia deslizamentos e desabamentos, com a lama confundindo-se com o espaço antes habitado. Os ventos que acompanham as precipitações erguem os telhados e permitem à chuva afetar os bens e os que se encontram na moradia, danos e perdas que o granizo potencializa. Raios comprometem os equipamentos domésticos e levam à fatalidade quando atingem pessoas. Assim, não é só a água que precipita que coloca as habitações frágeis em alerta, mas o volume, a velocidade, a qualidade daquilo que escorre; e, ainda, a intensidade dos ventos, a constância e a proximidade das descargas elétricas que estão associadas às densas nuvens (p. 171).

O que torna a situação ainda mais preocupante é, justamente, a relação entre risco, vulnerabilidade e culpa associados aos desastres. Mesmo em localidades como a Região Serrana do Rio de Janeiro em que eventos relacionados à chuva são bastante frequentes, o impacto das tempestades e consequentes desbarrancamentos não tornaram seus moradores nem as autoridades preparadas para lidar com o caos e as inúmeras perdas pós-desastre. Ano após ano, o caos e a destruição nestes mesmos municípios se repetem, como em um ciclo interminável de dor, sofrimento e angústia. Por que esta repetição? Algo está sendo feito para que este tipo de situação não se repita, evitando assim novas catástrofes?

Além do já exposto por Parkes (2009) sobre nosso despreparo emocional para situações catastróficas com base em nossa necessidade de sentirmo-nos no controle diante dos eventos cotidianos, temos que nos atentar para a construção social das noções de segurança e medo. Em uma situação de desastre, deparamonos, com algo inominável, terrível, assustador:

O medo é mais assustador quando difuso, disperso, indistinto, desvinculado, desancorado, flutuante, sem endereço nem motivo claros; quando nos assombra sem que haja uma explicação visível, quando a ameaça que devemos temer pode ser vislumbrada em toda parte, mas em lugar algum se pode vê-la (BAUMAN, 2008, p.8).

Bauman (2008) nos alerta que a forma como lidamos com nossos medos interfere diretamente na forma como reagimos frente a situações inesperadas. Nosso mundo presumido, apesar de individual e particular, é construído na 
relação com o mundo e é constantemente reelaborado nas inter-relações estabelecidas diariamente por cada individuo. Segundo o autor, se neste processo de construção de nossa subjetividade "ignorarmos" ou subestimarmos os riscos que corremos em nosso dia a dia, nossas reações diante de calamidades podem estar comprometidas.

Ao trabalharmos com desastres e suas repercussões nas diferentes comunidades atingidas, devemos nos atentar ao conceito de risco descrito por Morales-Soto et al. (2008), segundo o qual

O risco de um elemento exposto é definido como a possibilidade de sofrer danos em um lugar e momento determinados, assim como a probabilidade que se apresentem perdas e consequências econômicas e sociais devido à ocorrência de um fenômeno perigoso. No risco existem dois fatores envolvidos: a ameaça, vista como a probabilidade de ocorrência de um evento adverso, e a vulnerabilidade entendida como a suscetibilidade do elemento exposto ser afetado. (p.101)

A partir deste olhar, os autores entendem que as noções de risco, ameaça e vulnerabilidade estão diretamente relacionadas à compreensão que os sujeitos têm do perigo a que estão expostos em situações de desastre, compreensão esta que norteia e direciona os trabalhos de prevenção e orientação a população, os quais deveriam educar, elucidar e preparar os indivíduos para lidar com as intempéries. Estes conhecimentos, se transmitidos de forma clara e contundente, fortaleceriam nossos recursos de enfrentamento e, consequentemente, diminuiriam o número de perdas decorrentes dos desastres.

No entanto, quando a sociedade nos promete um invólucro protetor - seja através dos governantes, das propagandas ou quaisquer artifícios que nos convençam de que estamos no controle - ou promove a crença de uma fórmula para nos sentirmos seguros através de produtos e promessas oferecidos para garantir a integridade da grande massa, seguimos nossas vidas acreditando nessa ideia e, de forma geral, desastres e calamidades tornam-se eventos distantes, que atingem apenas outras pessoas e nunca nos alcançarão.

Não devemos esquecer que somos "apresentados" ao medo em nossas primeiras relações objetais, aquelas que estabelecemos com nossos eleitos (BOLWBY, 1998), quando estes, por exemplo, se afastam por um período, ou 
quando nos permitem avançar em nosso comportamento exploratório por conta própria. $\mathrm{O}$ medo não é neste processo de aprendizagem algo negativo, mas exige uma base segura para, aí sim, tornar-se uma fonte de crescimento, pois somente uma relação estável e sólida nos fornecerá o alicerce que sustenta nossa confiança e o sentimento de até onde podemos desbravar o mundo, sem colocar em risco a nossa integridade ou a de outrem.

A partir desta base, construímos nossas concepções acerca do medo e seguimos aprendendo com o meio o que podemos ou não explorar. Sentimo-nos seguros diante de situações em que outros se sentem hesitantes; tememos coisas que algumas pessoas simplesmente "tiram de letra". O medo, assim como a segurança, são sentimentos construídos na relação com o mundo, mas desenvolvem-se de maneira particular, e podem representar nossa salvação - ou perdição - em uma situação de desastre.

Isso se dá porque situações de desastre, segundo Bauman (2008), escapam ao nosso repertório conhecido e, por isso, ativam outras fontes de recurso para lidar com o caos e a desorganização comuns a este tipo de evento. $\mathrm{O}$ autor nos apresenta, ainda, o conceito de medo derivado, secundário à fonte do temor inicial, que é descrito como um resquício da vivência inicial de medo que nos mantêm alerta para situações de perigo (reais ou não). Segundo ele, o medo derivado é:

... o sentimento de ser suscetível ao perigo, uma sensação de insegurança (o mundo está cheio de perigos que podem se abater sobre nós a qualquer momento com algum ou nenhum aviso) e vulnerabilidade (no caso do perigo se concretizar, haverá pouca ou nenhuma chance de fugir ou de se defender com sucesso) (p.9).

Os desastres, sob essa perspectiva, tanto trazem à tona a sensação de insegurança como aumentam significativamente o sentimento de vulnerabilidade dos indivíduos - assim como de toda comunidade que está na iminência de ser atingida - e esta combinação pode elevar o pavor, a desorganização e as repercussões negativas. Por outro lado, é diante de situações calamitosas que muitas vezes emergem os sentimentos coletivos de reciprocidade, identificação e solidariedade, que podem se sobressair em meio ao caos. 
No caso do desastre da Região Serrana, avisos difusos foram emitidos por diferentes órgãos responsáveis pelas previsões meteorológicas, e as autoridades responsáveis optaram por administrar a informação baseados na expectativa de que as chuvas previstas para a região naquele período fossem relativamente controláveis (PORTAL G1, 2011). Já com posse da previsão final, não havia mais tempo hábil para medidas preventivas eficazes, e todo trabalho realizado se deu durante e após a catástrofe, não tendo sido possível evitar centenas de mortes ocorridas principalmente entre os dias 11 e 20 de janeiro de 2011.

Esta atuação tardia parece estar, em parte, relacionada ao conceito de risco e vulnerabilidade que já apresentamos anteriormente, frente ao qual parecemos muitas vezes ignorar ou preferir acreditar que, mesmo diante de eventos recorrentes, estamos a salvo; ou, como nos aponta Bauman (2008),

Só é possível nos preocuparmos com as consequências que podemos prever, e é só delas que podemos lutar para escapar. E assim, só as consequências indesejadas desse tipo "pré-visível" é que classificamos na categoria de "riscos". Esses são perigos de cuja probabilidade podemos (ou acreditamos poder) calcular: riscos são perigos calculáveis (p. 18).

No entanto, não só a recorrência de determinados tipos de catástrofe, mas também a incidência repetida destas em determinadas regiões do país gera inquietações. Este aspecto já havia sido apontado por Valencio (2010) quando esta nos afirma que

É imperioso refletir sociologicamente acerca dos agentes e do processo que transformam desastres mistos - isto é, produzidos na sinergia ou que imiscuem fatores distintos de ameaça - em desastres de causa única, sobretudo quanto esta causa é atribuída a um fenômeno natural, como as chuvas. Ao fazer recair explicações e alegações nos fenômenos atmosféricos, os responsáveis de carne e osso e/ou com personalidades jurídicas, podem flanar livremente pelo espaço social (p. 17-8).

É notório que existe uma discussão sobre a alocação das moradias e a constatação de que grande parte da população atingida pelas chuvas da ocasião estava habitando áreas de risco e, por esta razão, é compartilhada a opiniao de que os sobreviventes estavam deliberadamente se colocando em uma posição de 
perigo em caso de tempestades ou outros tipos de intempérie "natural”. É sabido que desbarrancamentos, deslizamos e enxurradas são mais comuns em regiões onde há encostas, e a construção de casas neste tipo de terreno aumenta a chance de que as construções sofram danos permanentes ou provisórios. Mas, mesmo diante deste fatos, podemos isentar os governantes de sua falta de preparo? Temos investido em educação e orientação à população residente destas localidades?

Como cidadãos expostos a estes eventos, cabe a pergunta: qual a noção de risco que estamos construindo em nossa sociedade? Que interesses sustentam a falta de investimento em medidas preventivas? O que leva as pessoas a se colocarem em situações ditas de risco, mesmo quando avisadas sobre estas condições? Se estas condições existem, quais as medidas cabíveis para a educação e, se possível, realocação dos moradores destas regiões? Como nos alerta Bauman (2008),

Para evitar a catástrofe, primeiro é preciso acreditar na sua possibilidade. É preciso acreditar que o impossível é possível. Que a possibilidade sempre espreita, inquieta, debaixo da carapaça protetora da impossibilidade, esperando o momento de irromper (...) considerá-las improváveis ou nem mesmo pensar nelas é a desculpa para não fazer nada contra elas antes que atinjam o ponto em que o improvável vira realidade e subitamente é tarde demais para aliviar seu impacto, que dirá impedir sua chegada (p. 24).

A responsabilização dos moradores das comunidades atingidas por parte dos governantes (e também por parte da própria população que observa os acontecimentos a uma distância segura) é comum nesses casos, em que os habitantes das regiões mais pobres das localidades devastadas são culpabilizados pela extensão dos danos ocorridos durante as tragédias, como fica evidenciado no próprio Anuário de Desastres - ano 2011:

Deve-se evidenciar que a maior parte dos óbitos ocorridos na Região Sudeste, 429, vincula-se aos desastres ocorridos na Região Serrana do Rio de Janeiro. Como já destacado anteriormente, os danos humanos ocorridos estão intimamente relacionados à ocupação desordenada de áreas com alta suscetibilidade a movimentos de massa, locais onde ocorrem diversas intervenções com cortes para a construção de moradias em encostas íngremes situadas na base de afloramentos rochosos (BRASIL, 2012, p.38). 
Mas não foram apenas os moradores de comunidades carentes que sofreram os impactos do desastre da região. Vejamos: por definição, enxurradas são “... desastres associados a escoamento superficial de alta velocidade e energia, desencadeadas por chuvas intensas e concentradas, frequentes em regiões acidentadas e bacias pequenas" (BRASIL, 2012, p.47). A susceptibilidade de uma localidade a esse tipo de evento pode estar relacionada a processos de impermeabilização do solo decorrentes de uma urbanização desordenada. Essa impermeabilização pode reduzir a capacidade de infiltração da água das chuvas e, em consequência disso, aumentar as chances de alagamento e a velocidade com que ocorrem os danos (poder destrutivo dos escoamentos).

A urbanização desordenada não está relacionada apenas aos segmentos mais pobres da população. Os perigos relacionados às chuvas são muitos e podem atingir todos os extratos sociais: desbarrancamentos, enxurradas, eletrocutamento por raios, contaminação por doenças trazidas pela água e fezes de animais, quedas em terrenos lodosos, desidratação, hipotermia, entre outros, todos envolvendo riscos à integridade física dos atingidos relacionados à ocupação urbana sem planejamento. Por isso, segundo Valencio (2011), temos que parar para refletir acerca do fenômeno das chuvas a partir de seus aspectos sociopolíticos, tendo em vista que a população mais atingida pelos deslizamentos e, consequentemente, mais responsabilizada pela destruição das cidades é, em geral, moradora das encostas locais:

Estão mais suscetíveis a desaparecer e morrer entes de famílias que, nos desastres, ficam situadas nos grupos desabrigados e/ou desalojados, posto que a destruição ou danificação severa de moradias gera grande parte de afetados em certos eventos, como nos episódios de chuvas torrenciais e em ocorrência no período noturno, circunstância em que a maioria dos membros da família se encontra repousando (VALENCIO, 2011, p.1).

Em vista de todos estes aspectos, como podemos classificar os eventos ocorridos na Região Serrana do Rio de Janeiro em janeiro de 2011? Por que tantos o chamam de maior desastre natural da história da região? Não seria ele uma catástrofe mista? Que tipo de suporte a população afetada recebeu? Seria este um evento isolado ou há um histórico de outras intempéries nas cidades atingidas? 


\title{
2.3 As chuvas da Região Serrana: desta vez, em janeiro de 2011
}

\begin{abstract}
O anúncio de uma catástrofe não produz nenhuma mudança visível, seja na nossa forma de conduta ou em nossa maneira de pensar. Mesmo tento sido informadas, as pessoas não acreditam na informação que receberam (...) o obstáculo mais terrível à prevenção de uma catástrofe é sua incredibilidade.
\end{abstract}

(DUPUY, 2002)

Um novo ano começou... 2011 chegou repleto de esperança em dias melhores. Muitos comemoraram mais este novo começo com energias renovadas, novos projetos e metas. Nunca poderíamos imaginar o que este início de ano nos reservava: apenas 11 dias se passaram após os festejos de Réveillon quando, em uma terça-feira, teve início o que foi considerada uma das maiores tragédias do Brasil até os dias de hoje.

O Megadesastre '11 da Região Serrana do Rio de Janeiro" ocorreu entre a noite do dia 11 e a manhã do dia 12 de Janeiro de 2011. Deixando um número incalculável de cicatrizes de escorregamentos em encostas de quatro municípios Nova Friburgo, Teresópolis, Petrópolis e Sumidouro -, principalmente nas duas primeiras, e provocando prejuízos indiretos por conta de enxurradas em mais três municípios - Areal, São José do Vale do Rio Preto e Bom Jardim. O "Megadesastre" provocou 912 mortes e deixou mais de 45.000 desabrigados e desalojados, caracterizando-se como o maior desastre registrado no Brasil e consolidando, infelizmente, a Serra Fluminense como a região brasileira com o maior quantitativo de vítimas fatais provocadas por desastres naturais $(40 \%$ do total nacional entre 1988 e 2012) (BRASIL, 2012, p.63).

Segundo reportagem online do Jornal Folha de São Paulo (FOLHA.COM, 2011), o Instituto Nacional de Meteorologia (INMET) registrou, na tarde do dia 11 de janeiro, previsores de que fortes chuvas atingiriam a Região Serrana do Rio de Janeiro, tendo emitido um aviso meteorológico especial às Defesas Civis estaduais e municipais por volta das 16 horas e 30 minutos. As prefeituras de Nova Friburgo, Teresópolis e Petrópolis teriam recebido os alertas, mas declararam não haver tempo hábil para tomar as medidas necessárias para evitar a tragédia. 
A Defesa Civil da capital fluminense ignorou, segundo a reportagem, os avisos de alerta emitidos pelo INMET e também pelo Centro de Previsão de Tempo e Estudos Climáticos (CPTEC) e optou por seguir as recomendações do Serviço de Meteorologia do Estado do Rio (SIMERJ), que não previa um temporal de magnitude alarmante.

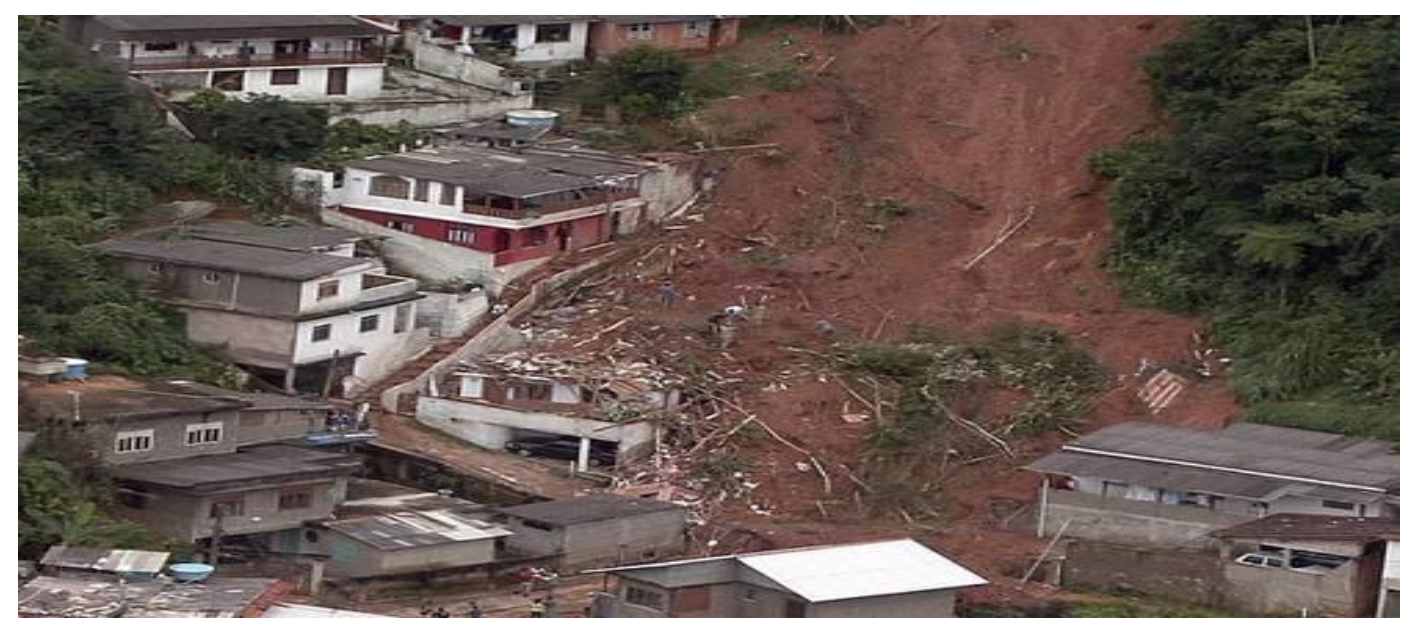

Figura 1. Destroços na cidade de Teresópolis-RJ (Fonte: O GLOBO, 2011).

Infelizmente, as previsões do INMET estavam corretas e, naquela mesma noite, teve início um período de aproximadamente 10 dias initerruptos de chuvas que variaram entre garoas fracas e tempestades torrenciais e atingiram as cidades de Petrópolis, Teresópolis, Nova Friburgo, São José do Vale do Rio Preto e Sumidouro, além dos municípios de Itaipava, Areal e Bom Jardim. Ao longo dos meses de janeiro e fevereiro, as localidades assoladas pelo desastre ainda passaram por inúmeros dias chuvosos, embora o ápice dos temporais tenha ocorrido de forma concentrada no início do ano. As consequências desse Megadesastre deixaram marcas em milhares de pessoas e são sentidas ainda hoje, 3 anos depois, pelas comunidades devastadas. De acordo com o Anuário Brasileiro de Desastres Naturais - ano 2011, a ocorrência de eventos desta natureza justifica-se nessa região pois:

A alta densidade demográfica aliada à ocupação desordenada em áreas de risco faz dessa região uma das que mais sofrem com as adversidades atmosféricas. Algumas das principais ameaças relacionadas ao tempo e clima são chuvas intensas, vendavais, granizos, geadas e friagens, secas, baixa umidade do ar e nevoeiros (BRASIL, 2012, p.16). 
As chuvas de janeiro de 2011 também foram classificadas como o maior desastre natural da história do Rio de Janeiro segundo o Relatório Estatístico Anual de Desastres confeccionado pelo Centro de Investigação sobre a Epidemiologia dos Desastres (CRED) da Organização das Nações Unidas (ONU, 2012b), assim como pelo Anuário de Desastres Naturais (BRASIL, 2012). Embora fenômenos pluviométricos não sejam, em geral, a maior causa de desastres no Brasil, estatísticas apontam a devastação dos eventos na Região Serrana.

A quantidade de óbitos verificada nesta região é 7,29 vezes maior do que a verificada nas outras quatro juntas, muito em razão do evento ocorrido na Região Serrana do Rio de Janeiro. Isso representa $87,95 \%$ do total de óbitos ocasionados por desastres no Brasil em 2011 (BRASIL, 2012, p.31).

O CRED estima ainda que, em 2011, contabilizando as chuvas da Região Serrana, os furacões registrados nos EUA, as tempestades nas Filipinas e o tsunami do Japão, a economia mundial teve um prejuízo de cerca de 366 bilhões de dólares devido a catástrofes naturais (ONU, 2012b). Estes gastos estão relacionados ao fornecimento de suprimentos de necessidade básica (como água, comida, remédios, transporte de feridos e das equipes de resgate), bem como a reconstrução das cidades e planejamento de contenção de danos futuros.

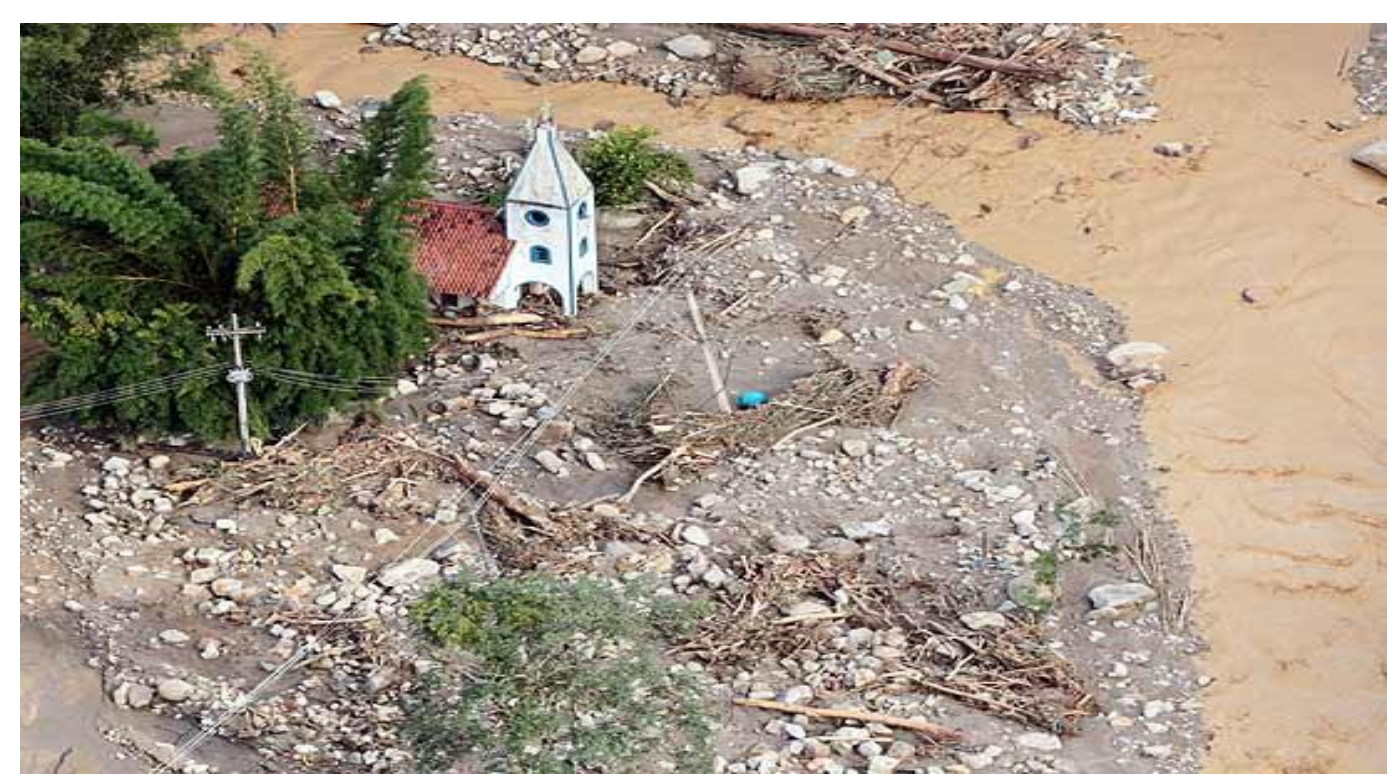

Figura 2. Chuvas levam a destruição de pontos centrais nas localidades atingidas (Fonte: $\mathrm{O}$ GLOBO, 2011). 
Infelizmente, as chuvas no estado não são nenhuma novidade e, em alguns aspectos, chegam a nos assombrar por suas semelhanças com outro momento histórico. Segundo Sedrez (2008), em 11 de janeiro de 1966 - mesma data das chuvas referidas em nosso estudo - ocorreu a pior tempestade já registrada na cidade do Rio de Janeiro, quando aproximadamente 250 milímetros de chuva caíram sobre a cidade em menos de 12 horas:

... em 11 de janeiro de 1966, uma tempestade violenta atingiu a cidade, As chuvas fortes e letais continuaram por mais uma semana, e provocaram o total colapso do sistema de transporte, assim como um "apagão" elétrico quase completo. Como se não bastasse, no ano seguinte novas chuvas, em janeiro e fevereiro de 1967, igualmente excepcionais em dimensões, causaram mais de 100 mortes no Rio de Janeiro e traumatizaram a cidade (SEDREZ, 2008, p. 01).

No ano de 1966, foram registrados diversos deslizamentos de terra, especialmente nas favelas, causando mais de 140 mortes. Foram dias de racionamento de gás, energia e principalmente água, pois esta havia sido contaminada pelo esgoto. Segundo a autora, novas chuvas ocorreram durante o verão nos anos de 1970, 1980 e 1988, ainda que menos intensas em relação ao volume de água.

Ao nos depararmos com estas estatísticas, não podemos negar esta terrível realidade: os eventos climáticos e suas repercussões não são (nem podem ser) compreendidos como fenômenos naturais imprevisíveis e inevitáveis mas, em grande parte, como consequência da falta de investimentos em prevenção e da precária assistência à população, o que leva a um número ainda mais alarmante de mortos e feridos todos os anos nas comunidades atingidas pelas catástrofes - sem falar no descaso aos diversos preditores identificados pelos órgãos responsáveis que têm sido ignorados, deixando centenas de pessoas ainda mais vulneráveis às intempéries.

Este tipo de conduta nega à comunidade os recursos para lidar com situações de emergência e falha em proteger seus cidadãos. Como nos aponta Sedrez (2008), o passado e o presente se confundem pois apontam para a total inércia e desinteresse dos governos anteriores e atuais, fazendo com que os sentimentos de medo e insegurança nunca cessem. 
Se chuvas são fenômenos naturais, enchentes são fenômenos sociais. A partir do século XX, o impacto das enchentes se torna mais evidente no cotidiano da cidade. A cidade moderna com suas ruas pavimentadas, prédios, concreto e asfalto, absorvia menos as águas pluviais do que a terra batida, os manguezais e as florestas que a precederam. E se chuvas normais já saturavam as galerias pluviais, chuvas excepcionais eram sinal de desastre. A população vivia ansiosa o início de cada ano, temendo as águas de janeiro, fevereiro ou março (SEDREZ, 2008, p.01).

O que mudou efetivamente de 1966 para 2011? Teríamos investido mais em prevenção de acidentes e desastres ao longo das décadas? Como entendemos a questão de responsabilidade em relação as diferentes perdas vividas em decorrência de um evento como este, que ocorre perodicamente? Como Sedrez (2008) constatou em sua pesquisa, a população na década de 60/70 mostrava-se bastante apreensiva com a chegada da estação das chuvas, o que ainda é visível na população nos dias de hoje.

O que nos chama mais a atenção é que nos dias de hoje, a previsibilidade de eventos pluviométricos está cada vez mais acurada devido ao grande número de descobertas tecnológicas no campo da Meteorologia, o que poderia (e deveria) ter elevado o potencial preditor para as comunidades, o que, consequentemente, lhes proporcionaria mais segurança e autonomia. No entanto, o que observamos é uma falta de medidas preventivas por parte dos órgãos governamentais ao mesmo tempo em que, por outro lado, há uma descrença da população com relação aos instrumentos de previsão meteorológica assim como nas entidades responsáveis pela segurança pública.

Presenciamos em diversas localidades do Brasil - e certamente na Região Serrana - um misto de incredulidade e conformismo dos que vivem em locais comumente afetados pelas chuvas sazonais, e estes sentimentos podem dificultar a elaboração das perdas que essas comunidades possam sofrer se atingidas por uma nova catástrofe. Enredamo-nos, muitas vezes, em uma teia de desculpas que nos paralisam pois, ao mesmo tempo, culpamos e somos culpabilizados pelos eventos que nos arrebatam. Ficamos presos e inertes em círculo vicioso insalubre que não gera as mudanças efetivas e eficazes para o problema das chuvas no Rio de Janeiro e nem aos demais estados de nosso país assolados por diferentes eventos climáticos. 
Ainda sobre esse tema, devemos retomar um tópico já apresentado anteriormente: como culpabilizar os moradores das encostas se o evento foi identificado pelos próprios estudiosos da área como um Megadesastre? Se uma das causas do elevado número de perdas na tragédia está relacionada a ocupação desordenada, como explicar os moradores "do asfalto" que também foram devastados pelas chuvas, deslizamentos e enxurradas? De acordo com o próprio Anuário de Desastres - ano 2011:

Desde o primeiro minuto do pós-Megadesastre, tanto nas vistorias de campo quanto nos sobrevoos de helicóptero, o que mais chamou a atenção foi o caráter absolutamente generalizado dos escorregamentos, que, ao não respeitarem a variedade de formas das encostas nem a gênese dos materiais geológicos dispostos à superfície, atingiram indistintamente setores urbanos e rurais, e, praticamente, todas as encostas suaves, íngremes ou escarpadas, sejam as compostas por solos residuais e transportados, sejam aquelas com depósitos de movimentos de massa pretéritos ou afloramentos rochosos (BRASIL, 2012, p.63).

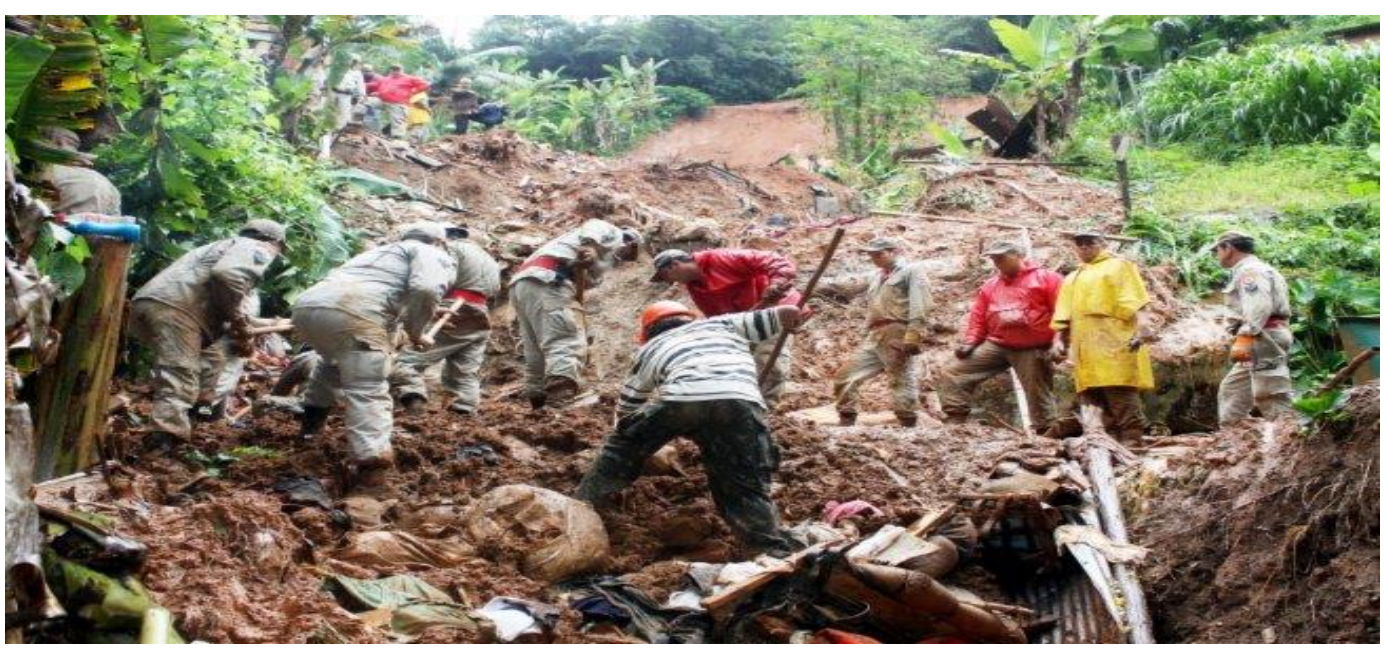

Figura 3. Bombeiros e funcionários da Defesa Civil procuram por sobreviventes (Fonte: $\mathrm{O}$ GLOBO, 2011).

Na tragédia da Região Serrana, além da falta de investimento em prevenção a desastres, o serviço de atendimento pós-desastre também foi bastante deficiente e, em muitos casos, evidenciou despreparo, falta de efetivo e tato dos profissionais envolvidos. Frente a esta realidade, muitos membros da comunidade se uniram e buscaram entre si o apoio que necessitavam (tendo em vista que muitos moradores da região também já haviam vivido outros momentos críticos por conta das chuvas comuns as localidades atingidas). 


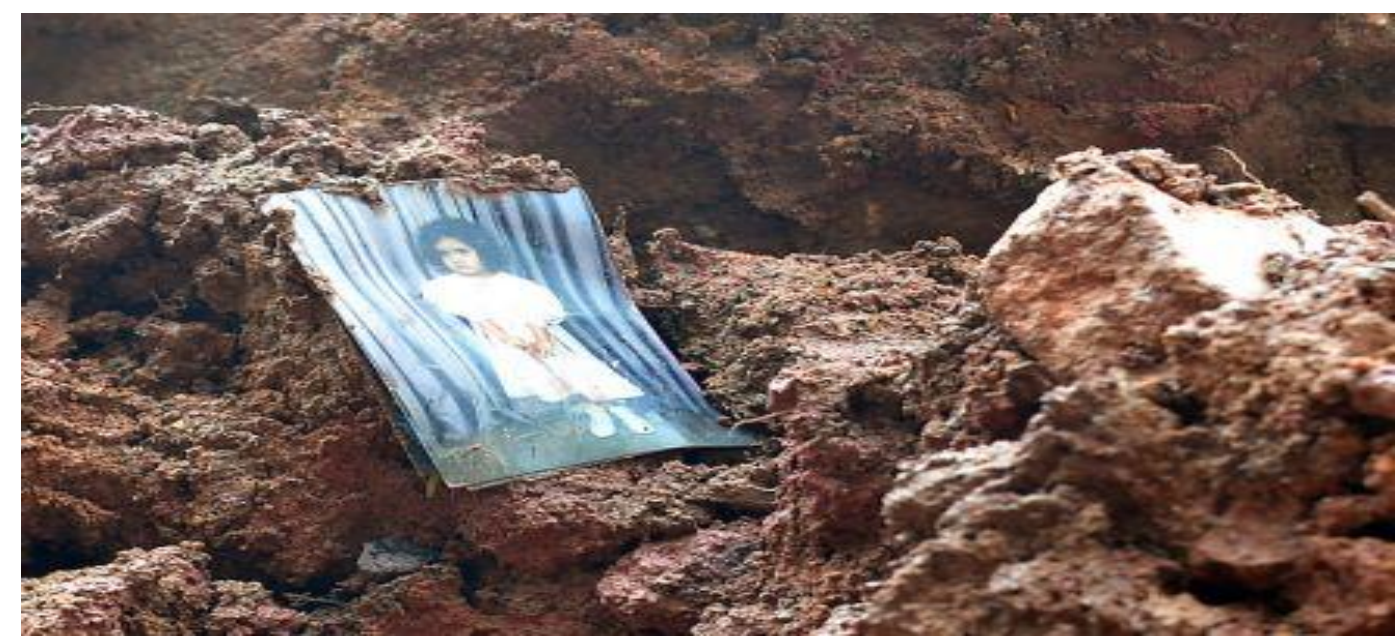

Figura 4. Pertences pessoais entre os escombros da tragédia (Fonte: O GLOBO, 2011).

Como Valencio et al. (2005) afirmam, experiências anteriores nos fortalecem para vivências repetidas frente a desastres, especialmente porque nesses contextos é comum que se construa no grupo uma intersubjetividade comunitária, ou seja: a união do grupo de pessoas atingidas pela catástrofe gera um conjunto de valores e princípios que potencializa o poder de reconstrução da comunidade, fato este facilmente identificável em tragédias como a da Região Serrana. Este fortalecimento do grupo também se dá a partir da já referida incredulidade nos órgãos responsáveis e o sentimento de desamparo dos sobreviventes.

... se deve à experiência comunitária, oriunda de desastres anteriores, que orienta para a necessidade de se envolver na decisão das medidas de proteção, haja vista a tendência de declínio drástico da atenção pública conforme o tempo passa. Não é apenas "informação" o que promoveria a proteção, mas o tipo de informação, o canal que a promove, como é transmitida, quem a recebe e como é interpretada (p. 169).

Não podemos deixar de enfatizar também que, além das perdas concretas/materiais vividas nos contextos de desastre, há também perdas de signos, status, papéis sociais, costumes, modos de comportamento e rituais que fazem parte do processo constitutivo do sujeito, e quaisquer decisões posteriores a estes eventos não envolvem apenas o indivíduo e sua família, mas também a comunidade, seus vizinhos e pessoas do entorno atingido que, juntos, formam uma importante rede informal de apoio (VALENCIO ET AL., 2005). 
Esta rede de apoio é fundamental pois é ela que mantém acesa a esperança dos membros da comunidade na resignificação do trauma vivido e, posteriormente, na continuidade da vida nas localidades atingidas, especialmente em casos como o da Região Serrana em que a tragédia se mantém viva não só pelas dificuldades de reconstrução concreta das comunidades devastadas, mas principalmente por ter entre suas baixas um número tão expressivo de pessoas desaparecidas, tema que trataremos a seguir.

\subsection{Desaparecimentos: a interminável e inominável ausência}

Para as famílias das pessoas que estão ausentes fisicamente, esse processo de despedida gradual é particularmente difícil porque deve ter lugar apenas em suas mentes.

(BOSS, 1999)

Em nossa pesquisa, propomo-nos a estudar a vivência de múltiplas perdas e, especialmente, a interface entre a experiência de indivíduos que foram arrebatados pelo desastre ocorrido na Região Serrana do Rio de Janeiro e que, em decorrência deste mesmo evento, vivenciaram o desaparecimento de pessoas queridas, cujos corpos nunca foram localizados. Para explicarmos melhor a realidade que estamos estudando, vejamos algumas estatísticas dos meses seguintes à catástrofe na região: os serviços governamentais contabilizaram, ao final do mês de março de 2011, 916 mortes e aproximadamente 345 desaparecidos, sendo 180 em Teresópolis, 85 em Nova Friburgo, 45 em Petrópolis e 2 em Sumidouro. De acordo com o Ministério Público, outras 32 pessoas nunca foram encontradas em diferentes localidades da Região Serrana e foram incluídas também no Cadastro de Pessoas Desaparecidas (FOLHA.COM, 2011).

Nos casos de desastres naturais como o ocorrido na Região Serrana, a maior parte da população atingida pelos deslizamentos e desbarrancamentos é moradora das encostas e comunidades carentes das cidades, sendo também o local que concentra o maior número de pessoas desaparecidas, pois como nos afirma Valencio (2011), 
Estão mais suscetíveis a desaparecer e morrer entes de famílias que, nos desastres, ficam situadas nos grupos desabrigados e/ou desalojados, posto que a destruição ou danificação severa de moradias gera grande parte de afetados em certos eventos, como nos episódios de chuvas torrenciais e em ocorrência no período noturno, circunstância em que a maioria dos membros da família se encontra repousando (p.1).

No caso da Região Serrana, as equipes de resgate e os próprios moradores permaneceram dia e noite escavando o terreno em busca dos ausentes. Para manter ativo o difícil trabalho de procura às pessoas desparecidas foi criado o Programa de Identificação de Vítimas - parte de outro projeto mais amplo, o PLID (Programa de Localização e Identificação de Desaparecidos) - uma parceria entre o Ministério Público do Rio de Janeiro (MP-RJ), a Polícia Civil, Defesa Civil, o Detran e o Corpo de Bombeiros. O procurador Rogério Scantamburlo, responsável pela organização da lista de pessoas desaparecidas na época da tragédia, afirmou:

"Não quer dizer que essas pessoas estejam mortas... estamos buscando... o objetivo é que esse número (de desaparecidos) chegue a zero, seja encontrando essas pessoas vivas, seja com a identificação dos corpos" (JORNAL DO BRASIL, 2011).

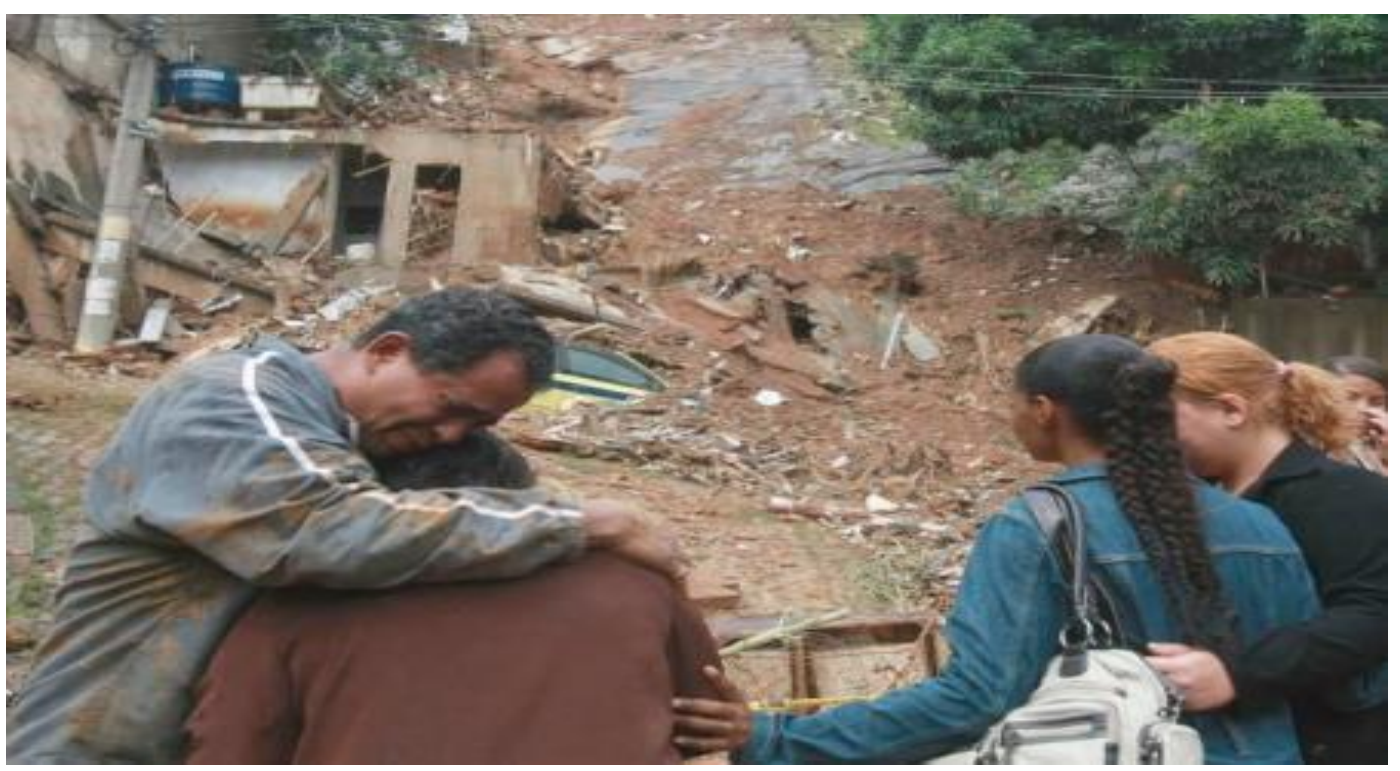

Figura 5. A dor e o sofrimento diante da tragédia (Fonte: O GLOBO, 2011).

No entanto, dia após dia de busca, a localização dos desaparecidos foi tornando-se uma missão quase impossível, visto que além do terreno instável 
pelas chuvas continuar cedendo (o que pode acarretar no deslocamento de corpos soterrados), havia também que se considerar o tempo de exposição destes a determinadas condições (corpos soterrados ou submersos durante muito tempo na água também tem mais chances de serem levados pela correnteza), o que dificulta a sobrevivência das vítimas, bem como leva a um processo de decomposição mais acelerado dos corpos.

Um ano após a tragédia, a triste constatação: cerca de 200 pessoas ainda estavam cadastradas em toda Região Serrana como desaparecidas. De acordo com dados atualizados no início do mês de janeiro de 2012, os números do Programa de Identificação de Vítimas apontavam que 137 pessoas não haviam sido localizadas no município de Teresópolis, 44 em Nova Friburgo, 18 em Petrópolis e 1 Sumidouro; além disso, outras 15 pessoas desaparecidas não tinham a origem definida (FOLHA.COM, 2012).

Segundo Hodgkinson \& Stewart (1998), para os sobreviventes, o desastre envolve a corrupção da inocência. Isto porque, dentre as inúmeras perdas a serem elaboradas no luto por um desastre, a perda da fé é um dos grandes fatores desorganizadores do funcionamento psíquico do enlutado. Não falamos aqui da fé religiosa, mas a fé inerente à experiência do bem viver, aquela que se sustenta no fato de que a vida tem consistência e significado. Sob esta perspectiva, sobreviver deve ser compreendido não somente como a diferença entre viver e morrer, mas envolve qualidade de vida e a condição de transformação diante da experiência traumática.

Diante do desaparecimento sem respostas de familiares e amigos, a família e a comunidade sentem esta fé ainda mais abalada frente aos impactos do Megadesastre. Inúmeras e indescritíveis perdas foram vivenciadas pelos moradores das localidades atingidas, muitas sem o fechamento desejado pelos enlutados. Como enfrentar tantos lutos consecutivos em tão pouco tempo? É possível ser resiliente em um contexto onde dor, desorganização, medo e impotência são vividos individual e coletivamente? 


\title{
3. "SEM EIRA, NEM BEIRA, NEM NADA..."
}

\begin{abstract}
Somente nós, seres humanos, temos consciência da inevitabilidade da morte e assim também enfrentamos a apavorante tarefa de sobreviver à aquisição desse conhecimento - a tarefa de viver com o pavor da inevitabilidade da morte e apesar dele.
\end{abstract}

(BAUMAN, 2008)

A frase que dá nome a este capítulo foi extraída da fala de um dos participantes que, ao descrever seus sentimentos diante da tragédia ocorrida na Região Serrana do Rio de Janeiro em 2011, resumiu nestas poucas palavras o caos e a devastação sentidos durante o desastre que assolou comunidades inteiras no interior do estado. É esta complexidade de sensações e percepções que movem nosso interesse por este tema em questão. Vale lembrar que, em nossa pesquisa, entendemos que a catástrofe ocorrida na região não pode ser definida apenas como um desastre natural, mas sim um evento de origem mista, principalmente por sua recorrência ao longo dos anos o que, consequentemente, poderia - e deveria - ter aumentado o potencial de prevenção ou, ao menos, de contenção de danos, o que não ocorreu de forma eficaz.

Nos capítulos anteriores, buscamos construir a base para atingirmos nosso objetivo principal: compreender a vivência de múltiplas perdas em contextos de desastre. Já definimos que perdas são inerentes à condição humana e que, ao estabelecermos relações de amor com objetos eleitos, estamos sujeitos também a sua ausência, e reagiremos à falta que estes nos fazem, seja este afastamento temporário ou definitivo. Em todo luto, haverá a necessidade de resignificar a relação com o que ou quem foi perdido a fim de restabelecer a ordem que inevitavelmente se rompe após uma separação (seja ela entre vivos ou pela morte propriamente dita).

Também compreendemos que desastres podem ter diferentes origens e níveis de intensidade mas, em geral, levam a uma crise - crise no sentido de um estado conflitivo que rompe o equilíbrio de um sistema e favorece sua desorganização (RENEDO, BELTRAN \& VALERO, 2007). Isso porque desastres geralmente acarretam em múltiplas perdas, sejam estas humanas e/ou 
materiais e como nos apontam Kirstensen e Franco (2011), pode levar a morte de várias pessoas da mesma família, o que “... priva o enlutado de seu sistema de suporte natural, e pode gerar sentimentos de sobrecarga de luto” (p.190).

Situações de crise sempre afetam as pessoas de diferentes formas e a capacidade de organização dos atingidos está diretamente relacionada aos recursos disponíveis em cada um individualmente bem como em seu grupo (FRANCO, 2005; VALERO ET AL., 2005). Em situações de emergência, muitos sobreviventes possuem uma boa capacidade de adaptação e resposta à crise, mas por serem diversas as esferas atingidas, esta segurança fica abalada, pois como aponta Torlai (2010), os desastres “... afetam padrões de vida das comunidades e suas redes de apoio psicossocial, colocando em risco a capacidade de enfrentamento individual e coletivo" (p.24).

Sabemos que todo luto demandará dos indivíduos um trabalho de reorganização e reinvestimento libidinal e, neste processo, algumas variáveis podem dificultar a elaboração das perdas vividas (e, neste capítulo, daremos ênfase às perdas decorrentes de uma catástrofe). De acordo com Grégio (2005) e Parkes (2009), perdas múltiplas e mortes súbitas, inesperadas e prematuras aumentam o risco de problemas de ordem física ou emocional, tendo em vista que nestes casos não há nenhum tipo de preparo anterior à perda. Além disso, o autor aponta ainda como outro fator de risco em situações de desastre o ato de "testemunhar violência ou mutilação, mortes com um culpado (incluindo assassinos e suicidas) e mortes que não permitem a recuperação de um corpo intacto" (p.45).

Para iniciarmos esta reflexão, devemos compreender, em primeiro lugar, a complexidade do fenômeno em questão: apesar de o luto ser uma reação esperada diante de uma perda significativa, ninguém está, de fato, preparado para lidar com situações catastróficas. A todo o momento estamos expostos a riscos das mais diversas naturezas, mas tendemos a banalizá-los, pois acreditamos que a ordem do mundo seguirá normalmente, dia após dia, sem maiores abalos, como programado (BAUMAN, 2008). Assim, seguimos nossos planejamentos, buscando viver a vida de forma tranquila e organizada, batalhando para vencer cada obstáculo que se faz presente em nosso cotidiano, mesmo sabendo que estamos, diuturnamente, ameaçados por inúmeras possibilidades de intempéries e fatalidades. 
A realidade é que, todos os dias, caminhamos em direção a nossa própria finitude, mas como não podemos precisá-la, evitamos "evocá-la", ou seja, prezamos a vida e o conviver; estabelecemos metas baseados em nossa compreensão de que o futuro é, de certa forma, previsível; lançamo-nos em projetos e desafios que celebram o que está por vir; e cremos que nossos feitos serão memoráveis para as próximas gerações.

Nesta trajetória, conectamos-nos aos nossos pares, fortalecendo laços com aqueles que elegemos para estabelecer nossas relações amorosas, fundamentados, principalmente, no que Parkes (2009) chamou de mundo presumido, que corresponde ao aspecto do mundo interno reconhecido como verdadeiro, através do qual fazemos suposições e concepções relativas a nós mesmos, à família, à comunidade a que pertencemos, aos grupos maiores nos quais estamos inseridos (étnicos, religiosos, sociais) e à capacidade desse mundo nos proteger.

Essa realidade conhecida abarca diversos significados e objetivos de vida e é construída continuamente não só pelo individuo, mas também na sua relação com a coletividade. De acordo com o autor, o mundo presumido é:

... aquele aspecto do mundo interno que é tido como verdadeiro (...) contém suposições sobre objetos (...) que nos permitem reconhecer tais objetos quando os vemos e planejar nosso comportamento de acordo com a necessidade, mas ele contém muito mais do que isso. Tudo que consideramos garantido faz parte de nosso mundo presumido. Aí estão incluídas nossas concepções sobre nossos pais e nós mesmos, nossa habilidade para lidar com o perigo, a proteção que podemos esperar dos outros (incluindo-se aí a polícia, o sistema legal e as pessoas ao nosso redor) e as incontáveis cognições que compõem a estrutura complexa de que depende nosso senso de significado e propósito na vida (PARKES, 2009, p.43).

O mundo presumido é, portanto, uma das mais importantes fontes de segurança de nosso repertório, e toda perda - em especial a de uma pessoa amada e estimada - implica em uma necessidade de revisão de nossas certezas, agora abaladas, ao mesmo tempo em que se vive o processo de luto. Importante frisar que o mundo presumido não deve ser entendido como algo estanque e imutável, e sim como uma dimensão dinâmica, que está em constante transformação onde novas informações são acrescentadas e antigas percepções são retiradas, dando mais consistência a nosso sistema de crenças. 
O trabalho de reavaliação do mundo presumido, especialmente após uma perda, é uma tarefa não só emocional, mas também cognitiva, e leva tempo; isto fica ainda mais evidente em casos de perdas inesperadas e traumáticas como as que ocorrem nos casos de desastre.

Nós sabemos, racionalmente, que desastres acontecem, mas se nossa experiência nos ensina que eles acontecem às outras pessoas e não acontecem comigo, então vamos adotar essa suposição básica e nos sentir seguros. Quando um desastre nos atinge, qualquer que seja a causa, nossa concepção básica de que o mundo é um lugar seguro é abalada e, muito rapidamente, ele se torna inseguro (PARKES, 2009, 169-170).

Ao longo de nosso processo de desenvolvimento normal, mudanças naturalmente acarretam em algum nível de desestruturação, demandando do sujeito e de seus grupos uma redistribuição de papeis para reestabelecer a ordem e a sensação de controle que nos dão segurança e ansiamos ter garantida essa pretensa previsibilidade sobre a vida. Se a desorganização é fruto de uma situação traumática, a desestruturação diante do inesperado e abrupto pode se dar de forma ainda mais avassaladora e desruptiva.

Mudanças e transições são inevitáveis no desenvolvimento do individuo e da sociedade (...) três ou mais mudanças ou transições, mesmo se esperadas e "normais" geralmente resultam em estresse. O estresse é precipitado pela desorganização do processo de transição, com aumento do nível de risco para os problemas e sintomas do individuo, da família e da comunidade. Quanto mais rápidas e numerosas são as mudanças, maior será o impacto da desorganização (KLINGMAN \& COHEN, 2004, p.61).

O processo de luto nunca é simples, mas em casos de desastres e traumas, nossos recursos internos - assim como os externos - parecem não dar conta da complexidade de variáveis envolvidas neste tipo de evento. Tudo que conhecemos torna-se estranho e desorganizado em um curto espaço de tempo; pessoas, objetos e lugares parecem frágeis diante do horror e do caos geralmente presentes em situações catastróficas e nossas segurança e tranquilidade se esvaem como se o chão se abrisse sob nossos pés. 
Um trauma é definido como uma ruptura no tecido vivo, causado por um agente externo, como resultado de uma cirurgia, um ato violento, um desastre. Geralmente leva a um estado de crise. Pode ser também definido como um período de desequilíbrio psicológico, resultante de um evento ou situação danosa, assim constituindo um problema significativo que não pode ser resolvido com as estratégias de enfrentamento conhecidas. Uma experiência traumática se dá quando uma pessoa se confronta com a morte, ameaça de morte, ferimentos sérios em si ou no outro e reações de intensa dor, desamparo ou horror (FRANCO, 2005, p. 177).

Segundo Janoff-Bulman (1992), situações traumáticas podem trazer consequências profundas à vida do sujeito, invalidando ou mesmo destruindo certezas até então inquestionáveis, levando a sentimentos de estranheza e incompletude, agravados pela certeza (pelo menos momentânea e temporária) de descontrole e imprevisibilidade em relação ao futuro. Quanto mais arrebatadoras e numerosas forem essas mudanças, mais difícil processar todas as crises advindas do evento traumático.

Parkes (2009) enfatiza que, em casos de desastre, múltiplas serão as perdas e ainda mais numerosos serão os enlutados, o que torna o trabalho de elaboração ainda mais difícil e doloroso, somados a um crescente sentimento de impotência e insegurança diante da vida. Como o autor afirma, "pessoas que experienciam perdas múltiplas não só sofrem os efeitos cumulativos do luto (...) sua suposição de que o mundo é um lugar seguro (...) é corroída e substituída por uma expectativa de futuros desastres" (p.161).

Corroborando com estes apontamentos, Souza (2011) afirma que a principal particularidade dos casos de desastre reside, justamente, na difícil tarefa de reconstrução, já que são muitas as esferas afetadas da vida dos sobreviventes:

Assim, podemos dizer que eventos que ocorrem de forma gradual e previsível permitem o planejamento, armazenamento de forças e estratégias de enfrentamento e a reconstrução pós-trauma. Desastres e adversidades naturais, previstos ou não, trarão perdas materiais, afetivas e sociais, fazendo com que as pessoas atingidas passem por um processo de luto. Ocorre que, juntamente com esse processo e sua elaboração, elas devem reconstruir suas bases, e não há tempo para se fazer uma coisa de cada vez. Durante o enfrentamento da situação, há que se avaliar as perdas, priorizar necessidades de sobrevivência e manter aquilo que não foi perdido (p.05). 
Diante de todo caos inerente aos desastres, são comuns sentimentos como medo, insegurança, impotência, confusão, desorganização, desalento, afobação ou até mesmo paralisação completa diante de tantos estressores combinados e concomitantes (JANOFF-BULMAN, 1992; VALENCIO ET AL., 2005; KRISTENSEN \& FRANCO, 2011). Estes temores estão relacionados, nesses casos, não só a iminência de ameaça a nossa própria integridade física, mas também a de nossos entes queridos, amigos e pessoas de referência (como vizinhos e colegas da comunidade).

Como nos apontam Morales-Soto e Alfaro-Basso (2008), há também, após a catástrofe, inúmeras repercussões nos planos laborais e sociais, que não só atingem as comunidades, mas também a estrutura macro que compõem:

Os desastres tem um impacto negativo nos países (...) pois além das perdas materiais (destruição da infraestrutura, gastos com saúde, reabilitação de serviços básicos, reconstrução de obras de interesse público), reduz o crescimento econômico por causa do fechamento de suas fontes produtivas (fábricas, agricultura, comércio), o que afeta o emprego, a produção e a arrecadação tributária (p.106).

Novamente deparamo-nos com uma particularidade dos desastres: seu alto potencial de destruição. Seja qual for a origem da catástrofe, é frequente que pessoas padeçam ou fiquem gravemente feridas; casas e outras construções são destruídas (parcial ou totalmente) e muitos são os danos à organização prévia das localidades atingidas. Além das perdas humanas irreparáveis (e, possivelmente, as mais dolorosas), inúmeras são as perdas simbólicas ligadas à identidade dos sobreviventes, o que, de certa forma, também se configura como uma espécie de morte (MARCHEZINI, 2011).

Assim sendo, as perdas vivenciadas após um desastre são múltiplas e complexas, pois atingem os indivíduos em diversas esferas da vida - sejam elas afetivas, econômicas, laborais e sociais - e demandam destes uma gama de recursos frente ao alto nível de desorganização interna e externa (podendo acarretar, como já referido anteriormente, até mesmo em um estado de choque e total paralisação do sujeito). Como lidar com este terrível quadro onde o caos impera? Perdas concretas e simbólicas ocorrem simultaneamente: como lidar com tantos lutos concomitantes? 
De acordo com Morales-Soto et al. (2008), devemos compreender que os desastres possuem como principais características sua complexidade causal, seu caráter cíclico (relação entre recorrência e sazonalidade), a previsibilidade do evento (e, neste ponto, os autores enfatizam que os desastres naturais, embora intempestivos, não podem ser considerados inesperados devido a sua recorrência), a quantidade e extensão dos danos, além do alto custo que isto poderá gerar as autoridades envolvidas na atenção e reconstrução das áreas atingidas.

Segundo Valencio et al. (2004), em torno de 500.000 pessoas morrem todos os dias em todo o mundo, e cerca de $20 \%$ destes falecimentos são decorrentes de catástrofes tais como guerras, acidentes e desastres, o que implica em um número ainda mais expressivo de pessoas enlutadas por todos os que padecem diariamente em consequência deste tipo de evento. Os autores apontam também que entre 15 e $25 \%$ das pessoas expostas a eventos traumáticos como desastres necessitam de assistência especializada por problemas psicológicos associados ao trauma, sejam eles sobreviventes diretos (que estavam presentes no local do desastre) ou indiretos (que não presenciaram o evento em si, mas foram impactados por este de forma intensa e avassaladora).

No caso dos sobreviventes diretos, Valero et al. (2004) apontam que, durante o desastre, podemos identificar sentimentos de intenso mal estar, inquietude, irritabilidade, angústia, desamparo e insegurança, além de medo de perder entes queridos ou até a própria vida. Dentre os sintomas físicos o estudo cita dores de cabeça, vômitos (ou ânsia de), fadiga, sudorese, sensação de "aperto" no peito/taquicardia, tremores, calafrios, desmaios, tensão muscular e dificuldades para respirar. Já entre as reações motoras, destacam-se dificuldades para dormir e comer, fala acelerada, rompantes de raiva e agressividade (auto ou heterodirigida), retraimento, isolamento, nervosismo, comportamentos antissociais, abuso de medicamentos, hiperatividade ou passividade diante dos acontecimentos. Apesar de todo impacto negativo causado pela catástrofe, os autores identificaram também sentimentos de heroísmo e invulnerabilidade, euforia, gratidão por ter sobrevivido, solidariedade e empatia para com os demais acometidos pela intempérie.

Já nos dias que se seguem à catástrofe, as reações podem ser descritas como ansiedade antecipatória, busca errática e compulsiva pelos entes queridos e 
intenção de recuperar a unidade familiar, acompanhados por uma forte tensão até que se obtenham dados concretos sobre a realidade pós-desastre. Alterações no sono e na alimentação ainda estão presentes, além de uma necessidade imperiosa de contar repetidamente a experiência vivida. Entre as reações cognitivas, os autores identificaram dificuldades de concentração e na tomada de decisões, perda de interesse em atividades antes prazerosas, incapacidade de formular novos planos e metas, negação de fatos e emoções, confusão e desorientação, medo de novas ocorrências que possam levar a um risco de morte, hipervigilância e até mesmo alucinações. Ficou evidenciado também que os sobreviventes atribuíram causas externas ao evento traumático (tais como fenômenos da natureza, falta de responsabilidade e comprometimento das autoridades e até mesmo azar). Os sentimentos de solidariedade e empatia se mantêm, agora mais organizados e racionais (VALERO ET AL., 2004).

Diferentes autores (VALERO ET AL., 2004; PARKES, 2009; KRISTENSEN \& FRANCO, 2011) fazem referência também a um fenômeno ao qual denominaram como culpa do sobrevivente, no qual muitos sobreviventes passam a apresentar como reações pós-desastre não só sentimentos de culpa, mas também ideações obsessivas (do tipo “por que não eu?”), irritabilidade, ira e agressividade, além de desordens psicofisiológicas como hipertensão, cefaleia e transtornos gastrointestinais. Segundo Kristensen e Franco (2011), é comum o sentimento de não ter feito o suficiente para salvar os que morreram e "... o alto grau de incertezas e o baixo nível de controle da situação podem levar a reações de estresse de alta intensidade" (p. 190).

Quanto à memória do trauma, Franco (2005) aponta para as dificuldades que os sobreviventes podem ter para recordar os eventos ocorridos a época do evento estressor ou, em contraposição, revivê-los constante e vividamente, principalmente através de flashbacks dos momentos de perigo - a revivescência de experiências traumáticas pode se dar até mesmo através de imagens, sonhos ou percepções sensoriais como cheiros e sons. Ainda segundo a autora,

Outras reações ao trauma incluem evitação de eventos associados (...) esforço para evitar pensamentos, sentimentos ou conversas associadas ao trauma; (...) evitar atividades, lugares ou pessoas que lembrem a pessoa perdida ou o próprio evento traumático; inabilidade em lembrar algum aspecto importante, 
relacionado à negação da perda; inabilidade para sentir e apegar-se (FRANCO, 2005, p.179).

Já entre os sobreviventes indiretos de um desastre, Valero et al. (2004) descrevem um quadro que denominam como Síndrome de Aflição por Catástrofe, que segundo os autores se apresenta como uma dor imensurável pela perda dos entes queridos acompanhada de sentimentos de ira, tristeza, ansiedade, preocupação excessiva e sensação prolongada de pesar. Condutas regressivas, isolamento e apatia também são frequentes, assim como o aumento do número de casos de abuso de substâncias (lícitas e ilícitas).

Em ambos os casos - sobreviventes diretos e indiretos - é possível identificar um predomínio de reações emocionais em detrimento do lado racional. A desorganização das rotinas, a ausência de rituais e a desestruturação familiar e da comunidade após um desastre podem levar também a um aumento dos casos violência, além de elevar as ocorrências de depressão e suicídios (LANDAU \& SAUL, 2002; LEE, 2002). As diferenças entre os tipos de desastre também podem influenciar as reações psicológicas ao longo do processo de luto, como quando ocorrem mortes percebidas como possíveis de serem prevenidas e não o foram por negligência ou desinteresse, o que pode levar a raiva excessiva e amargura.

Segundo Franco (2005), o evento traumático pode desencadear um quadro de Reação Aguda ao Estresse - cujos sintomas surgem logo após a emergência e tem remissão dos mesmos em cerca de um mês - ou através do Transtorno de Estresse Pós-traumático - no qual o surgimento dos sintomas pode ser tardio em relação ao evento traumático ou ser identificado pela persistência dos mesmos por um período superior a um mês. Assim também alertam Kristensen e Franco (2011):

Apesar da maioria das pessoas parecerem se recuperar bem do estresse associado aos desastres, para muitos sobreviventes as perdas estão associadas com problemas de saúde mental a longo prazo, tais como transtorno de estresse póstraumático, depressão e transtorno de luto crônico (p.189).

Este alto nível de desorganização decorrente dos desastres ocorre, principalmente, porque os atingidos se veem inesperadamente destituídos de sentido e de uma base segura para seguirem com suas vidas como antes, tendo em 
vista serem muitas as mudanças simultâneas e que atingem não só o sujeito individualmente, mas também sua família e diversos grupos de referência, podendo gerar ainda mais angústia, medo e impotência.

O que pode nos resgatar quando o desastre destrói todas as nossas referências? Tudo aquilo que nos confere identidade pode desaparecer em poucos instantes. Inevitavelmente, nossa identidade está apoiada nas coisas que conquistamos, nos papéis que desempenhamos e nos relacionamentos que estabelecemos na comunidade da qual fazemos parte. Nossa vida se organiza em torno desses aspectos (MARCHEZINI, 2010, p.01).

Seria possível classificar ou sequer mensurar estas perdas? Como processar tantos lutos? É possível resgatar ou desenvolver novas estratégias de enfrentamento quando nossas bases estão tão frágeis? O apoio dos familiares e demais membros da comunidade pode servir de suporte para o processo de elaboração dos lutos quando esta rede também está completamente desamparada e também enlutada? Para compreender esta complexa realidade, vejamos algumas das perdas mais frequentes em um contexto de desastre.

\title{
3.1 Entre mortos e feridos, há também os desaparecidos
}

\begin{abstract}
Quando a morte é finalmente confirmada, a incerteza e o desespero são substituídos por sentimentos de tristeza assim como de alivio. Encontrar os falecidos proporciona aos familiares a oportunidade para o enterro apropriado e uma tumba para visitar, o qual promove o fechamento. Infelizmente, desastres de larga escala geralmente resultam em corpos não localizados. Essas perdas também chamadas perdas ambíguas, podem trazer sentimentos de desesperança, depressão, somatizações, a conflitos de relacionamento.
\end{abstract}

(KIRSTENSEN \& FRANCO, 2011)

Desastres, por definição, são eventos que afetam diversas esferas públicas e levam a um alto nível de desorganização individual, social e político, tendo como um dos principais medidores de gravidade o índice de mortes decorrentes do 
evento catastrófico. Como Marchezini (2011) nos aponta, perdas humanas são inevitáveis em situações de desastre, e são consideradas as mais dolorosas diante de todo o quadro pós-desastre.

Em geral, o número de mortes em catástrofes é sempre elevado, e sofre maiores ou menores variações de acordo com os recursos que o local atingido possui para bem assistir os sobreviventes. Perdas de pessoas significativas já abalam naturalmente nossas estruturas, especialmente pelo componente amoroso a que Bowlby (1958) chamou de monotropia, segundo o qual,

... o amor é um vínculo com uma pessoa específica apenas. Não há como existir substituto para o pai, filho ou parceiro amoroso que tenha sido perdido (...) as pessoas não são substituíveis e cada novo relacionamento será único por si. Por esse motivo, o valor de cada pessoa que amamos é incalculável. Não podemos avaliá-las como fazemos com objetos utilitários ou passíveis de reposição (BOLWBY, 1958, apud PARKES, 2009, p.13).

$\mathrm{Na}$ maioria dos desastres, as mortes ocorridas deflagram três importantes fatos: a) a violência inerente a qualquer catástrofe (a qual atinge pessoas, lugares e instituições); b) a dificuldade do resgate dos feridos (o que será determinante para o prognóstico destes sobreviventes); e c) a árdua tarefa de localização e posterior identificação dos corpos dos que padeceram nos locais atingidos pelo desastre.

É certo que, em situações catastróficas, centenas de pessoas são atingidas e, dentre estas, muitas padecerão, e como nos apontam Kristensen e Franco (2011), devido a violência natural dos desastres, muitos corpos serão mutilados, desfigurados e/ou completamente destruídos. Ainda segundo os autores, “... isso pode privar os familiares da oportunidade de ver o falecido, o que é considerado importante no processo de confrontação da realidade da perda” (p.190). Nos casos de desastre como o ocorrido na Região Serrana em que municípios inteiros foram devastados e as condições dos terrenos são frágeis e precárias, a localização de corpos pode demorar dias ou até meses, e em alguns casos, é possível que estes sequer sejam localizados, impossibilitando assim a realização dos ritos familiares e sociais desejados. A perda de pessoas queridas já é uma dor difícil de ser superada, e quando este luto é acompanhado de tantas incertezas, o processo de elaboração fica, sem dúvida, em risco. 
Para muitos familiares de vítimas dos desastres, a localização dos corpos é de extrema importância, pois é a partir desta identificação que se iniciam os rituais de despedida do ente querido. Para estes sobreviventes, lidar com a condição de desaparecido de um membro da família é desestabilizador e angustiante. Trata-se de uma morte presumível, inconclusiva, da qual resta apenas a memória de uma presença física do outro que, subitamente, sumiu em decorrência de um fator externo ameaçador. Em outras palavras, deflagra uma separação involuntária e permanente sem um fechamento concreto.

A ausência física de um ente amado não impede que este permaneça emocionalmente presente, e esta presença é sentida como algo inquietante e pode perpetuar-se por tempo indeterminado (BOSS, 1999). O desaparecimento é, em muitos sentidos, uma condição pior do que a daquele que, falecido, teve seu corpo recuperado e identificado pela família, pois a condição de desaparecido impede que seus enlutados realizem seus rituais sociais, e mesmo que todos os indícios sejam de que este tenha sucumbido em decorrência do desastre, os sobreviventes acabam permanecendo em um estado de espera permanente, envolvidos em sentimentos de ansiedade e culpa (MATOS, 2004).

Sobre as famílias que permanecem esperando notícias de seus entes desaparecidos, a pergunta impera: é possível, diante de tamanha tragédia, manter a esperança de reencontrar seu familiar ainda com vida? Pensando nas várias localidades isoladas em decorrência da queda de pontes e barreiras, o que deixou diversas pessoas em áreas remotas da região sem nenhuma forma de comunicação, como não crer na sobrevivência de quem se ama?

Depois do desastre, é comum haver um período de espera antes de todos os corpos serem encontrados e identificados e a morte possa ser oficialmente confirmada. Esse é um período de grande estresse, com parentes oscilando entre sentimentos de esperança e desespero. A incerteza pode sustentar a negação da perda e fantasias acerca do desaparecido não estar morto o que pode retardar ou prolongar o processo de enlutamento (KRISTENSEN \& FRANCO, 2011, p.190).

Vemos, com alguma frequência, casos de pessoas localizadas dias, meses ou até mesmo anos após o desaparecimento, o que pode reforçar nos familiares as crenças sobre um possível retorno dos que estão ausentes. Como afirma Boss 
(1999), “dada a falta de certezas, é compreensível que as pessoas continuem a manter a situação, pois de certa forma esperam que a pessoa desaparecida retorne algum dia” (p.38).

Valencio (2010), em trabalho com sobreviventes do desastre no Morro da Baú/SC, observou que assim que as chuvas tornaram-se menos frequentes, as missões de busca pelos corpos dos desaparecidos não recomeçaram; diante dessa interrupção, algumas famílias se sentiram completamente desrespeitadas e abandonadas pelas autoridades, obrigando-as a vivenciar o luto “... de forma indigna, como que desprezando a memória do ente perdido numa coletividade em que os laços de parentesco valiam demasiados” (p.10).

Este é um temor comum entre os enlutados que possuem familiares desaparecidos, que gostariam que as atividades de busca se encerrassem apenas quando todos os ausentes fossem localizados, o que, infelizmente, não ocorre em todas as situações de desastre. Nos primeiros momentos após um desastre, a esperança de resgate de um familiar desaparecido é compreendida e estimulada; no entanto, com o passar do tempo, as chances de localização tornam-se mais remotas, mas muitos familiares insistem na certeza de sobrevivência do ente querido, enquanto outras já tomam como verdade absoluta a morte do amado ausente. Ambas as reações podem indicar uma negação diante da vivência traumática, o que não é raro em casos de perda ambígua, como Boss (1999) nos alerta.

Apesar da negação por vezes ser saudável, como quando ajuda a família a manter o otimismo, pode ser prejudicial quando anula as pessoas e as deixa impotentes. Nestes casos, a negação toma duas formas que se opõem dramaticamente, ambas problemáticas. Por um lado, as pessoas negam que perderam algo (...) e se portam como se nada tivesse mudado (...) por outro lado, as pessoas se portam como se o ser querido já tivesse saído completamente de suas vidas (p.85).

Como já referimos anteriormente, é comum que os sobreviventes atribuam responsabilidades pelas perdas vividas a agentes externos tais como à natureza, à falta de recursos que garantam segurança aos cidadãos e até mesmo à falta de empenho ou interesse dos profissionais envolvidos nas buscas e resgates. A espera 
agoniante e a falta de fechamento nestes casos são devastadoras, o que já havia sido apontado por Kristensen e Franco (2011) quando estes afirmam que “... $a$ necessidade por informações sobre o que aconteceu e o que está sendo feito para resgatar ou localizar o familiar desaparecido é iminente, especialmente nas primeiras horas e dias após o desastre” (p.190).

Muitos enlutados em situação de desastre sentem-se completamente abandonados ou excluídos do processo de localização dos corpos de seus entes queridos, e sentimentos de impaciência, frustração, agonia e desalento são característicos nesta etapa do processo, intensificados pela impossibilidade de velar seus parentes. Como nos aponta Matos (2008),

Vai daí a morosidade do ente público na busca por desaparecidos num desastre ser testemunhada com grande expectativa e um encerramento oficial prematuro das buscas ter a conotação simbólica de uma rudeza adicional no trato com os familiares sobreviventes, àquela altura das perdas todas havidas. Os faz tomar por concluído algo que ficou socialmente inconcluso; adotarem a crença num perecimento provável sem o respaldo dos meios de verificação aceitáveis do corpo da cultura dos entes vinculados; darem por esgotado os mecanismos de restaurar as relações abruptamente cessadas (p.01)

Como seres sociais, realizamos diversos tipos de celebrações que marcam as diferentes mudanças vividas ao longo de nosso ciclo vital, as quais podem estar relacionadas tanto ao amadurecimento biológico - como no momento do nascimento ou o ingresso na vida adulta - como à morte. Estamos inseridos em uma cultura particular e cada grupo estipulará seus rituais de passagem, especialmente quanto a forma apropriada de como devemos nos comportar em relação ao morto e a seu corpo. Estas práticas, respeitando cada crença e religião, têm como objetivo garantir a transição do falecido da vida física para o mundo espiritual ou, ao menos, possibilitar o último adeus ao ente amado (KOURY, 2003). O ritual mortuário permite também que o enlutado possa simbolizar, reconhecer e validar a morte na presença de outros membros da família e dos grupos de referência (SAPORETTI, 2009). Segundo Belatto e Carvalho (2005), todos os grupos preocupam-se em não abandonar seus mortos e empregam suas energias para prestar-lhes as devidas homenagens antes da última despedida. 
A condição de desaparecido deixa os enlutados em um estado de alerta indefinido, cheios de expectativas e, ao mesmo tempo, receios. Permanecer como desaparecido impede que os familiares e demais membros da comunidade enlutada se expressem e se despeçam e, como aponta Valencio (2011), “... um misto de tristeza e esperança é ruminado sem se equacionar a contento, além de exigir esforços e tempo extra na garantia de direitos que a presença de um cadáver, reconhecido, daria” (p. 52). Quando este corpo não pode ser velado da forma desejada, o impacto é inevitável e o processo de elaboração da perda fica, inegavelmente, comprometido.

Em muitos desastres, o término das buscas por sobreviventes e corpos dos não localizados é sentido como uma ofensa ou mesmo um descaso com as famílias enlutadas. Como vimos, este encerramento é visto como precoce e arbitrário e gera ainda mais angústia e dor aos que ansiosamente aguardavam por um fechamento desta dolorosa etapa de seu processo de luto. Além disso, as dúvidas sobre o que de fato ocorreu ao familiar desaparecido geram ainda mais angústia e impotência, já que acreditam que sua localização poderia responder a algumas perguntas que permanecem sem esclarecimento quando este não é encontrado.

Em consequência disto, constatamos que, em situações de emergência e desastres, aqueles que procuram por pessoas desaparecidas tendem a fazer o que Boss (1999) chamou de apostas da família como recurso de enfrentamento da perda. Muitas famílias buscam nos profissionais responsáveis e membros das equipes de resgate as respostas para seus questionamentos - tais como se as pessoas podem sentir dor durante um soterramento, quanto tempo é possível sobreviver em situações de desastre (quando estão sob a terra, presas sob os escombros, exposta a altas ou baixas temperaturas, entre outros) ou quanto tempo é possível sobreviver em localidades remotas sem água ou alimento.

Essa busca incansável por informações e explicações visa aplacar a dor de não saber nada sobre os últimos momentos de vida do ente ausente; porém, devido à ambiguidade própria à situação, podem acabar servindo como justificativas para que os membros da família mantenham acesa a esperança de reencontro com o desaparecido, o que, a longo prazo, pode acarretar em um quadro de luto inibido (pautado, principalmente, em uma negação da perda) ou crônico (devido a 
impossibilidade de resignificar a perda já que esta não se encerra sem um corpo que materialize a morte).

Vamos olhar sob o ponto de vista da família e da comunidade atingidas: quando se encerram os trabalhos de Bombeiros e Defesa Civil, estariam errados os sobreviventes que se sentem abandonados? Obviamente sabemos que situações de desastre podem levar a destruição total e completa dos corpos de pessoas soterradas ou arrastadas pelas enxurradas, mas devemos alertar, sobretudo, que o ato de interromper as buscas e concluir que os desaparecidos estão efetivamente mortos e não poderão ser localizados pode deflagrar não só limitações de recursos e dificuldades de acesso às áreas atingidas, mas também uma falta grave de planejamento e uma despreocupação dos órgãos envolvidos que, de antemão, deveriam garantir a segurança e o bem-estar de sua população, e mais:

A prática de encerramento de buscas revela-se como um sinal, um discurso institucional velado: indica a todo o grupo sobrevivente, sobretudo aos empobrecidos em suas territorialidades precárias, que o seu destino final, assim como o foi sua trajetória, pode ficar no vácuo de providências públicas, sendo isso algo socialmente aceitável (MATOS, 2008, p.01).

Para compreendermos melhor esta questão, cabe explicar que, juridicamente, quando não há nenhum indício, pista ou informação sobre o paradeiro de uma pessoa, o termo legal é ausente. Quando na condição de ausente, elege-se um curador de bens em caráter provisório para que, futuramente, possa ser definido um administrador definitivo para o patrimônio do mesmo. Já quando se utiliza a palavra desaparecido, entende-se que o sujeito esteja morto, mas não tenha sido localizado por variáveis diversas (como, por exemplo, nos casos de desastre, devido às condições das comunidades atingidas e o grau de periculosidade em seguir com as buscas).

Em casos de desastre, é a partir do encerramento das buscas que os órgãos responsáveis declaram, publicamente, o óbito dos até então considerados desaparecidos, utilizando como base os artigos 22 a 39 do Código Civil (BRASIL, 2002) e os artigos 1.159 a 1.169 do Código de Processo Civil (BRASIL, 1973) que versam sobre o uso do termo desaparecido, compreendido legalmente como aquele individuo cujo paradeiro se desconhece ou cuja morte se presume, embora 
não se tenha descoberto seu cadáver. No entanto, o próprio termo presunção de morte é carregado de ambiguidades, pois seu significado está relacionado à “... consequência que a lei faz deduzir de certos atos ou fatos e que fica estabelecida como verdadeira, às vezes até mesmo havendo prova em contrário” (HOUAISS, 2001, p.2294).

Após a definição do sujeito como ausente ou desaparecido, são providenciados os documentos legais; no caso dos desaparecidos, são emitidas as certidões de presunção de morte e, posteriormente, os atestados de óbito. No entanto, como afirma Oliveira (2007),

... judicialmente, falar em 'desaparecido' é indicá-lo como morto. Esta definição, de uso comum, de certa forma, fere as expectativas de todas as famílias que buscam noticias de seus parentes ou conhecidos desaparecidos, uma vez que buscam, sobretudo, pessoas vivas (p.20).

É comum também, após o encerramento das buscas e das providências legais pertinentes, que as entidades responsáveis ofereçam aos sobreviventes e demais enlutados rituais simbólicos - em muitos casos, coletivos - que visam proporcionar aos indivíduos a possibilidade de despedirem-se de seus entes queridos. Rituais são formas de expressão fundamentais para a família e amigos enlutados, pois

A morte suscita todo um gestual (...) que varia de tempos em tempos e de grupos para outros (...) estes gestuais expressos nos diversos costumes mortuários, nas formas de representação do 'além' nos mitos e nos ritos, denotam uma atitude diante da morte e do morrer e se constituem como sistemas de crenças (PESSOA, 1996, p.6).

No entanto, em situações de desastre, estes rituais geralmente ocorrem com caixões vazios e acompanhados de atos ecumênicos, o que para muitos enlutados fere a crença e o desejo familiar deste ato de despedida tão particular de cada crença e religião. Apesar de fornecer um local e uma sepultura para que os desaparecidos possam ser visitados e homenageados, com vistas a criar assim espaços de ventilação e validação das perdas para famílias e demais enlutados, Matos (2004) nos aponta que 
...o corpo esteja enterrado e, no entanto, sem sepultura, significa desaparecer, destituído de um lugar determinável, sem monumento, sem um espaço de luto circunscrito, localizável. Sem um "lugar", os mortos se tornam espectros. Esse luto, ou antes, sua impossibilidade, é ausência de pensamento (...) inviabilizando transformar o horror, um choque, um perigo, em experiência (p.294).

Podemos pensar que, em casos como o da Região Serrana, este tipo de ritual coletivo e com validação por diferentes religiões responde apenas parcialmente a uma demanda social e política de que estes mortos devem ser lembrados como vitimas de uma tragédia nacional; no entanto, suas famílias e os demais enlutados não alcançam, com esses ritos, um fechamento de suas perdas não solucionadas, já que tem consciência de que, nestes sepulcros, não há um corpo nem outro elemento que tenha concretizado a perda, que permanece como uma ferida aberta e não cicatrizada.

\section{2 "Não tinha teto, não tinha nada..."}

Sem ela (casa), o homem seria um ser disperso. Ela mantém o homem através das tempestades do céu e das tempestades da vida. É corpo e é alma.

(BACHELARD, 1993)

Além das mortes e desaparecimentos ocorridos após um desastre, muitas outras perdas são vivenciadas e devem ser administradas pelos enlutados que, individual e coletivamente, terão a árdua tarefa de reconstruir suas vidas e também a de reerguer sua comunidade. Como nos aponta Parkes (2009), “... perdas inesperadas podem abalar nosso mundo presumido e minar os vínculos mais seguros, do mesmo modo que as perdas múltiplas" (p.160). Uma das perdas mais comuns após catástrofes (especialmente as pluviométricas) é a das moradias, que envolve a perda não só da casa como estrutura física, mas também do local de união e proteção da família. 
A casa pode ser feita de tijolos e cimento; de madeira ou até mesmo de materiais mais rústicos, mas em seu interior, a casa é mais que uma construção concreta: ela é morada de pessoas, projetos, sonhos e conquistas de cada um de seus habitantes. Uma moradia nos remete não só a proteção física, mas também a conforto, harmonia e segurança. É um espaço repleto de cheiros, cores, marcas, desejos, lembranças, momentos. Casa e lar são aspectos complementares no imaginário dos seres humanos.

Quando nos referimos a casa, geralmente nos remetemos à imagem concreta de portas, janelas, paredes e chão que compõem a estrutura física e material do local onde residimos; já quando nomeamos como um lar, pensamos imediatamente nas pessoas que este abriga e nos momentos bons e ruins que vivemos dentro dele - remetemo-nos a um local que nos proporciona a sensação de pertencimento, convivência e apego (MARCHEZINI, 2011). Da mesma forma, Perrot (1991) nos aponta que a casa é o lugar “... das aprendizagens mais pessoais, tópico das recordações de infância (...) a casa é o sítio de uma memória fundamental que nosso imaginário habita para sempre” (p. 321). É neste espaço real que se constrói e se desenvolve, simbolicamente, o núcleo familiar.

Nos casos de desastre, os sobreviventes diretos e indiretos podem ser desabrigados ou desalojados. Segundo Castro (2003), desabrigado é “... pessoa cuja habitação foi afetada por dano ou ameaça de dano e que necessita de abrigo provido pelo sistema” (p.52) enquanto desalojado é a “... pessoa obrigada a abandonar temporária ou definitivamente sua habitação em função de evacuações preventivas, destruição ou avaria, decorrentes do desastre e que, não necessariamente, carece de abrigo provido pelo Sistema” (p.52). Em ambos os casos, os moradores precisam ser removidos de suas residências, e este nunca é um procedimento indolor.

Para muitos sobreviventes, o ato de abandonar suas casas é algo incompreensível e altamente desorganizador, especialmente em casos como o desastre da Região Serrana, em que centenas de pessoas foram surpreendidas pela força das chuvas e consequentes desbarrancamentos na área, tendo que ser rapidamente evacuadas de suas residências sem nem ao menos terem tempo de recolher seus pertences de valor (real ou simbólico). 
O que muitos cidadãos e profissionais envolvidos (bombeiros, funcionários da Defesa Civil, entre outros) se perguntam é: mas o que há de tão incompreensível no ato de abandonar a casa quando se está diante da iminência de destruição e possível danos a si mesmo e seus entes queridos? Mas é justamente diante de situações catastróficas que fica evidente o quanto estabelecemos relações de apego também com nossos lares e o valor sentimental envolvido na relação entre morador/moradia é tão forte que pode colocar a vida dos atingidos em risco quando estes não querem deixar suas casas.

Como nos afirmam Gladwin et al. (2001), em situações de catástrofe sempre existem pessoas que decidem permanecer em suas casas devido a esta relação que estabeleceram com o imóvel. Homens idosos, proprietários de suas casas e que há muito já estão estabelecidos na comunidade são, segundo os autores, os mais resistentes a deixar o local. Nas casas onde há familiares doentes que recebem tratamento domiciliar ou estão sob os cuidados de algum parente e que poderiam sofrer (ou até mesmo falecer) se transportados para hospital ou abrigo, a decisão é, também, a de permanecer no local, assim como as famílias que têm animais de estimação e não tem como levá-los junto para os abrigos temporários costumam optar por não abandonar a residência, apesar de todo o risco.

Além de a moradia reforçar nossa concepção de pretensa segurança no mundo (e a casa é um dos nossos lugares eleitos no mundo), é nela que depositamos muito de nosso tempo e de nossos ganhos materiais e onde desfrutamos de momentos familiares e com amigos; ser desalojado ou desabrigado é mais que estar sem um teto - é estar sem um chão onde muitas vezes recarregamos as forças para enfrentar os obstáculos do cotidiano; é ser alijado de parte de nossas memórias individuais e coletivas; é perder uma das mais importantes referências de nossa história e de nossa família. Como nos apontam Valencio et al. (2005),

Mesmo quando esta avaliação é a de que há um alto risco pessoal em jogo, o fator de manutenção da congregação familiar é um dos mais relevantes para a decisão, ao lado das crenças e das experiências passadas (...) a preocupação com aqueles com quem se mantém laços afetivos é fundamental, sejam eles parentes, sejam animais de estimação ou vizinhos (...) o "estar junto" faz mais sentido para os membros da família do que se proteger individualmente às custas do abandono do outro à própria sorte (p.170). 
Além da segurança e do conforto que a casa nos proporciona, é neste espaço físico que depositamos muitas de nossas conquistas - como quando compramos um novo eletrodoméstico ou um móvel, um objeto de decoração ou fazemos uma reforma para ampliar ou melhorar o espaço compartilhado - fruto do trabalho e do empenho dos provedores que se dedicam a manter a casa e pagar as despesas da família. Desta forma, a casa também reflete o trabalho e a capacidade laboral de seus moradores.

No entanto, a aquisição de bens materiais não é apenas ter e consumir objetos, mas está sempre associado à alegria da conquista (assim como às preocupações, como quando o bem material foi comprado em parcelas, por exemplo) e ao prazer em compartilhar com os familiares, vizinhos e amigos cada nova vitória. Cada objeto, cada mudança, cada parte da casa aponta não só para o trabalho que gerou o dinheiro que os proporcionou, mas principalmente o compromisso e a determinação para adquiri-los e que, de alguma forma, reflete parte da identidade de cada membro da família que deles usufrui.

Não podemos esquecer que, geralmente, guardamos em nossas casas objetos de valor sentimental, tais como fotos, presentes, objetos de decoração ou de uso da família, roupas e documentos que fazem parte de nossa história. Estes bens não costumam ter um alto valor monetário, mas são únicos e insubstituíveis pois dizem respeito a momentos e memórias muito particulares dos membros da família. Sendo assim, a perda dos bens materiais e de valor sentimental é, também, a perda de parte dessa identidade, de sonhos e projetos conquistados (ou ainda em execução) e pode gerar sentimentos de angústia, frustração, perplexidade, medo do futuro e sentimentos de menos-valia (MARCHEZINI, 2010).

Se além da casa, há também a perda do emprego, o sujeito perderá também sua fonte de renda, o que lhe impossibilita de reaver bens similares, aumentando ainda mais a sensação de impotência e desesperança diante de tantos lutos. Questionamentos surgem com frequência, como nos aponta Marchezini (2010).

Diante da perda da casa, dos bens materiais, do terreno, às vezes do próprio trabalho, a demanda por informação por parte das famílias abrigadas se refere, sobretudo, ao modo como reconstruirão, de um ponto de vista material e imaterial, o "daqui para frente" (p.01). 
Além das perdas humanas e materiais vivenciadas pelo indivíduo e sua família, ainda podemos citar a perda de locais de referência como escolas, igrejas, locais de trabalho e outras instituições das quais todos fazemos parte. Estes locais unem pessoas em diferentes momentos do processo de desenvolvimento e contribuem significativamente para o crescimento não só individual, mas também do grupo como um todo. Para muitos, são os locais de congregação com os demais membros da sociedade que ajudam a construir os sentimentos de pertencimento, identidade, compaixão, companheirismo e solidariedade.

Todos os sobreviventes fazem parte de diferentes grupos sociais e exercem papeis importantes para a manutenção da ordem de sua comunidade, sendo retroalimentados nas relações com os pares. Perder estes papeis pode levar a um alto nível de desorganização e retomá-los leva tempo (como, por exemplo, no caso do emprego e da escola que dependem de um espaço físico para existir). No caso das igrejas, não podemos restringir o espaço de fé apenas ao templo/igreja/congregação, mas é fato que a existência destes locais representa também a instituição de um espaço de troca, aprendizagem e união, local sagrado para seus frequentadores por representar a conjugação entre espiritualidade e irmandade.

Todos esses componentes formam um conjunto fundamental em nosso repertório identitário e a perda de desses referenciais - ainda mais quando estas perdas são concomitantes - pode acarretar em uma maior desestruturação, desorientação e impotência, levando a novos questionamentos sobre o que o futuro lhes reserva, como constatou Valencio (2010),

A perda súbita de parentes, vizinhos e amigos, além da destruição simultânea do espaço de moradia e do trabalho, numa comunidade com tão sólidos laços sociais e com a terra, agia como um fator de enorme sofrimento para os que sobreviveram. Muitos dos papéis que compunham a sua identidade, cotidianamente reafirmada no habitus, estavam para sempre descartados por causa da ausência do Outro que o justificava até então: mães sem os filhos, esposas sem os maridos; avós sem os netos (p.09).

Podemos afirmar, desta forma, que o desastre - seja ele de origem natural, humana ou mista - jamais atingirá apenas uma pessoa isoladamente, já que, por definição, catástrofes representam um alto grau de desestruturação coletiva e 
originam uma série de desdobramentos posteriores ao evento principal que também exigem o envolvimento da comunidade afetada. $\mathrm{O}$ número de perdas sempre deverá conter não só as do grupo de pessoas atingidas diretamente, mas também das inúmeras vítimas indiretas - familiares, vizinhos, membros da comunidade - assim como acaba envolvendo todo o município, a cidade, o estado e também o país.

\title{
3.3 Memória e trauma: do testemunho à narrativa, da narrativa à reconstrução
}

\begin{abstract}
O luto é uma das experiências mais estressantes que podemos enfrentar e todas as pesquisas nesse campo precisam ser realizadas com sensibilidade e tato. Isso posto, cabe dizer que muitas pessoas enlutadas gostam de compartilhar seus pensamentos sobre uma experiência tão importante e também que pesquisadores de boa fé, claros acerca de suas intenções e respeitosos aos desejos das pessoas enlutadas, geralmente perceberão o quanto elas desejam ajudá-los.
\end{abstract}

(PARKES, 2009)

Ao trabalharmos com pessoas enlutadas, é comum que as lembranças sejam repletas de dor, angústia, sofrimento, mas são também o retrato de uma voz que não quer calar, a palavra que falta, o que muitos não querem ou não podem, mas devem ouvir.

Halbwachs (1990) afirma que lembrar é o ato de buscar no passado histórias e trazê-las para o presente, mas este lembrar necessita do outro, daquele que testemunha. Para o autor, esse outro tem um papel fundamental não só na construção das lembranças, mas principalmente no processo de rememoração das mesmas, pois é ele (o outro) que enriquece fatos, cores, cheiros e nuances, anunciando ou reforçando detalhes muitas vezes esquecidos. Neste sentido, embora o indivíduo carregue em si suas lembranças, essas têm sempre relação com um grupo; não existe memória puramente individual: a lembrança é construída a partir de um social, ou melhor dizendo, ela é coletiva. 
Esse processo de rememoração coletivamente construído se dá mesmo quando aquele que testemunha estava ausente do momento a ser lembrando pois,

Nossas lembranças permanecem coletivas e nos são lembradas por outros, ainda que se trate de eventos em que somente nós vimos (...) não é preciso que outros estejam presentes, materialmente distinto de nós, porque sempre levamos conosco e em nós certa quantidade de pessoas que não se confundem. (HALBWACHS, 1990, p.30).

A lembrança, para o autor, é reconhecimento e reconstrução: é reconhecimento, pois se refere ao "sentimento do já visto"; é reconstrução, principalmente porque não é uma repetição linear de acontecimentos e vivências do passado, mas sim um resgate destes no contexto de interesses atuais, assim como é diferenciada em relação à massa de outros tantos acontecimentos e vivências evocáveis, pois é elegidamente localizada em um tempo, espaço e conjunto de relações sociais, emparelhando os tempos passado e presente, possibilitando novos caminhos.

Em situações de desastre, pessoas vivenciam o caos, estejam elas presentes ou ausentes nos locais devastados. Quando além de sobreviventes são também testemunhas dos eventos que se desenrolam em decorrência da catástrofe, é quase impossível que não presenciem perdas humanas, materiais e dos lugares antes conhecidos. A exposição a eventos traumáticos pode acarretar diversos sintomas àqueles que dele são testemunhas; no entanto, em situações de desastres de origem natural, é comum que estas testemunhas também sejam os moradores das localidades atingidas, o que os torna também os enlutados pelas perdas decorrentes a este mesmo evento.

Dentre os sintomas possíveis, podemos citar as recordações intrusivas do episódio. Estas lembranças recorrentes e imperiosas são vividas de forma intensa e são evocadas, especialmente, pelos estímulos humanos, sociais e ambientais a que estão relacionadas. Segundo Grégio (2005), a relação entre recordações e ambiente leva, em geral, a sintomas como evitação e embotamento. A esquiva persistente a estímulos associados ao trauma refere-se não só a esquiva de pessoas ou lugares que nos remetam ao trauma, mas também a fuga dos pensamentos, sentimentos e demais atividades que possam remeter o sujeito à cena traumática; em alguns casos, há uma recusa tácita em falar sobre o assunto. A amnésia 
também se pode ser uma das chamadas "estratégias de proteção" frente às lembranças do trauma.

Outro fator de risco para a saúde dos enlutados é a constante repressão às expressões públicas de pesar. Segundo Koury (2001), tendemos a nos envergonhar e calar sentimentos como dor e tristeza, pois sentir-se desolado e angustiado em nossa sociedade atual está associado à fraqueza e despreparo. $\mathrm{O}$ distanciamento que hoje buscamos da morte eleva as expectativas sociais de que rapidamente superemos o luto e sigamos em frente com a vida. Rememorar os eventos traumáticos pode ser compreendido como uma incapacidade de superar estes lutos, o que pode não ser bem aceito pelos demais membros da sociedade.

Apesar de, em casos de desastre, ser comum que a sociedade de uma maneira geral sinta-se enlutada - principalmente pelo número elevado de mortes, pela idade dos enlutados (muitas crianças e jovens falecem em situações catastróficas) ou pela sensação de total desespero retratada nos jornais e revistas após um evento de ampla magnitude - Koury (2001) nos alerta que somente os períodos iniciais após a perda de algo ou alguém querido são permitidos e validados, tornando-se a cada dia mais intolerável aos "de fora" suportar expressões de dor e sofrimento relacionados ao evento traumático.

A individualização crescente das relações sociais no Brasil atual parece tender a refrear o processo de individuação do sujeito que sofre a perda, através do mascaramento da dor do sofrimento e da morte. Essa tendência social de escamoteamento da expressão pública dos sentimentos e a valorização da interiorização, enquanto subjetividade ou espaço da intimidade ou do privado (e, nesse caso, não social por definição), cria uma pré disposição permanente no indivíduo à desconfiança no outro, e por extensão, no social (p.49).

Isto fica evidente quando observamos que, embora a tragédia da Região Serrana tenha atingido centenas de pessoas e suas repercussões tenham tomado conta dos diversos meios de comunicação por semanas, aos poucos as notícias sobre a população afetada e sobre os impactos do desastre tornaram-se mais escassas e foram substituídas por reportagens sobre novos acontecimentos. As muitas organizações que se uniram para prestar ajuda humanitária aos sobreviventes foram, pouco a pouco, deixando as cidades, mesmo que ainda muito 
tivesse que ser reconstruído. A mensagem velada por trás do esquecimento é de que já era hora de deixar a tragédia no passado e seguir em frente, pois os mortos na catástrofe não mais retornariam e não é aceitável manter-se fixado em algo que é irreversível. O pedido foi claro: vivam e nos deixem viver, apesar de tudo.

Seligmann-Silva (2003), no entanto, fala justamente da importância da memória em situações traumáticas, afirmando ser imperativo não esquecer de lembrar. Ao pensarmos nos conceitos apresentados por Halbwachs, a memória nos é a todos legada. Não há como esquecer. Importante dizer que não se trata de considerar como algo positivo as recordações intrusivas comuns a pessoas expostas a vivências traumáticas; trata-se de, a partir da experiência de ser sobrevivente de um desastre, poder lembrar e, neste ato de recordar poder narrar, ser sujeito de sua própria história, resignificar os eventos, compreendê-los, darlhes sentido após o caos vivenciado. Mais do que isso, “... a memória do trauma é sempre uma busca de compromisso entre o trabalho de memória individual e outro construído pela sociedade" (SELIGMANN-SILVA, 2008, p.67).

Ainda segundo o autor, o testemunho em situações catastróficas é elementar; é no ato de narrar que o sobrevivente inicia seu processo de reconstrução e de restabelecimento de relações com o mundo. Estes relatos durante o evento em si podem ser absolutamente terapêuticos pois,

O testemunho (...) é marcado pelo tempo do presente (...) o ato de testemunhar tem o seu valor (...) para além do valor documental ou comunicativo deste evento. A cena do testemunho (...) é sempre paradoxalmente externa e interna ao evento narrado. Interna porque em certo sentido não existe um "depois" absoluto da cena traumática, já que esta (...) é caracterizada por uma perenidade insuperável. Por outro lado, o testemunho é externo (...) na medida em que ele cria um local metareflexivo. (...) poder testemunhar durante uma situação traumática (...) já é uma saída (mesmo que apenas simbólica) desta situação. (SELIGMANN-SILVA, 2008, p.79-80).

Portanto, o trabalho com sobreviventes de desastres não está relacionado apenas à reconstrução após a vivência traumática relacionada às perdas vividas durante e após a catástrofe, mas também a uma resignificação do mundo presumido, a assunção de responsabilidades por seus deveres, bem como para que este possa resguardar seus próprios direitos, de forma que estes eventos não se tornem isolados e destituídos de sentido coletivo, e que não se valha a máxima de 
que desastres só acontecem com os outros (e muito menos de que "um raio não cai duas vezes no mesmo lugar"). É fundamental que a comunidade possa ser reconstruída não só no aspecto físico/estrutural, mas também em sua força como grupo, como coletividade ativa.

Como afirmam Schmidt e Mahfoud (1993), “... a memória coletiva apresenta-se como a solução do passado no atual; apresenta-se como recomposição (...) como algo que cura as feridas do passado." (p.293). É deste ponto que partimos para nossa pesquisa. Acreditamos na importância de testemunhar, de trazer para si a história que foi construída junto à família, aos amigos e demais sobreviventes. É poder se apossar de algo que é seu, dos seus e nosso também. É deixar que esta história nos envolva e desenvolva em cada um de nós a consciência de que todos perdemos algo naquele mês de janeiro de 2011. 


\section{MÉTODO}

\subsection{Objetivos}

\subsubsection{Objetivos gerais}

- Investigar as repercussões do desaparecimento de um ente querido diante de uma situação de desastre, na qual outras perdas se apresentam à família, tais como perdas materiais, de moradia, de trabalho e de recursos de saúde;

- Investigar as reações diante da constatação do desaparecimento do familiar, a busca por informações e paradeiro deste e as possibilidades e impossibilidades diante do caos vivido por toda a comunidade.

\subsubsection{Objetivos específicos}

- Investigar a vivência de ser sobrevivente de um desastre, quais as reações diante das perdas individuais e da comunidade da qual faziam parte;

- Investigar o impacto das perdas materiais: que bens foram perdidos, quais objetos de valor financeiro e/ou sentimental foram arrebatados pelas chuvas e quais as repercussões destas perdas para si e para a família;

- Investigar a vivência de ser desalojado/desabrigado e a ida para abrigos e outras moradias provisórias

- Investigar o apoio da rede após o desastre, tão fragilizada ela mesma por estar também de luto pelas perdas na comunidade.

\subsection{Participantes}

Foram participantes deste estudo 20 moradores das cidades de Petrópolis, Teresópolis e Nova Friburgo, região serrana do Rio de Janeiro, sobreviventes das chuvas ocorridas no estado no mês de janeiro de 2011. O contato com estes se deu, inicialmente, através da parceria com profissionais voluntários da Cruz Vermelha Brasileira, a qual prestou atendimento médico e psicológico às vitimas e familiares da tragédia na época em ocorreram os temporais na região. 
Como pré-requisitos para a realização da coleta de dados, foram estabelecidos 2 critérios: todos os participantes deveriam ter pelo menos um membro da família desaparecido em decorrência da catástrofe e, ao mesmo tempo, terem sofrido algum outro tipo de perda também devido ao desastre natural.

Para atingir nossos objetivos, contamos novamente com o apoio dos voluntários da Cruz Vermelha Brasileira que, durante as chuvas, ajudaram os sobreviventes e demais famílias locais a montar um Cadastro de Pessoas Desaparecidas, coletando fotos e informações que pudessem ajudar na localização e/ou identificação dos desaparecidos. De posse destas informações e com a mediação dos voluntários no contato com os possíveis sujeitos, iniciamos as entrevistas propriamente ditas. A partir destes primeiros contatos, utilizamo-nos do método "bola de neve", no qual um participante nos indicou outro possível entrevistado, com o qual fazíamos contato e, após esclarecido sobre os objetivos desta pesquisa, voluntariava-se (ou não) para nos contar sua história.

Para assegurar os critérios éticos estabelecidos para pesquisas com seres humanos, fornecemos aos participantes o Termo de Consentimento Livre e Esclarecido (Anexo II), no qual constam todos os dados pertinentes deste estudo e os objetivos da pesquisa, bem como a garantia de não participação e/ou desistência em qualquer etapa da pesquisa, ou seja: todos foram informados de que poderiam interromper a entrevista a qualquer momento e desistir da participação no estudo sem prejuízo para si ou outrem. Os que aceitaram participar tiveram suas identidades preservadas e, por esta razão, todos os nomes utilizados nos relatos são fíctícios, mantendo assim a segurança e sigilo das informações coletadas. Somente após assinado o documento supracitado, demos início às entrevistas.

As entrevistas foram realizadas entre os meses de junho e setembro de 2012 nas cidades já referidas, aproximadamente um ano e meio após as chuvas que dizimaram comunidades inteiras em mais de seis cidades da Região Serrana do Rio de Janeiro. Foram utilizados espaços como consultórios de Psicologia (Petrópolis), abrigos temporários as vítimas (Teresópolis) e casas de familiares onde estavam os desabrigados (Teresópolis e Nova Friburgo). 
Foram realizadas entrevistas únicas com duração, em média, de 1 hora e 30 minutos, no qual utilizamos um Roteiro de Entrevista Semidirigido (Anexo I), que prevê perguntas pertinentes à pesquisa ao mesmo tempo em que permite ampliar os assuntos de acordo com as histórias relatadas pelos sujeitos. O roteiro pré-elaborado de entrevista visa facilitar a sistematização e codificação dos dados coletados; porém, vale apontar que este roteiro serve unicamente como um norteador, mas permite que o pesquisador tenha flexibilidade frente aos conteúdos trazidos pelos entrevistados pois, embora seja previamente elaborado e direcionado em relação ao tema de pesquisa, possibilita também a expressão de conteúdos emergentes, sem perder de vista o objetivo do trabalho. Além das informações trazidas verbalmente nas entrevistas, também foram observados os comportamentos não verbais, tais como postura corporal, expressões faciais, gestos, dentre outros, os quais foram anotados em um diário de campo, recurso complementar aos dados coletados nas conversas.

Dentre os entrevistados temos 12 mulheres e 8 homens, todos com idade entre 25 e 53 anos, moradores das cidades de Petrópolis (7), Teresópolis (7) e Nova Friburgo (6). Todos moravam nas referidas cidades há pelo menos 10 anos destes, 9 participantes nasceram e sempre moraram na mesma localidade. Entre as mulheres, 8 são casadas, 2 vivem em união estável e 2 são divorciadas; entre os homens, 7 são casados e apenas 1 é divorciado. Todos os participantes têm filhos; entre as mulheres, todas residiam com os filhos; no caso dos homens, apenas o participante divorciado morava sozinho e cumpria o calendário de visitas aos filhos de 15 em 15 dias, de acordo com decisão judicial. A idade dos filhos variou entre 2 e 20 anos, mas a maioria tem idade escolar e está cursando o ensino regular fundamental ou médio.

Outro dado importante é sobre a renda familiar: todos os entrevistados trabalhavam antes do desastre e contribuíam para a renda da casa. As famílias residem (ou residiam) em moradias próprias ou alugadas e toda renda da família era empregada no sustento e desenvolvimento de seus membros, o que compreende gastos mensais com a casa, pagamento de escola (ou material escolar) dos filhos e pequenos lazeres familiares (cinema, passeios aos finais de semana ou festas de aniversário). Entre as mulheres, 5 são empregadas domésticas/diaristas, 4 trabalhavam no comércio da cidade (vendedora, estoquista 
ou caixa), 1 era embaladora de supermercado, 1 escrivã e 1 auxiliar de Pet Shop; já os homens, 3 trabalhavam em uma fábrica de automóveis (linha de montagem ou produção), 2 como funcionários da Construção Civil, 1 gari, 1 entregador de pizza e 1 jornaleiro.

\subsection{Apresentação dos casos}

\section{- Mônica}

Mônica é residente na cidade de Petrópolis, tem 42 anos, trabalha como embaladora em um supermercado no Centro da cidade e é casada há 20 anos com Maurício, corretor de imóveis, pai de seus 4 filhos, com idades de 17, 15, 10 e 6 anos na época da entrevista. Mônica e a família residiam no bairro de Madame Machado, local fortemente atingido pelas chuvas na região. Na casa ao lado da sua, moravam seu irmão, a cunhada e 2 sobrinhos menores de idade; no momento dos desabamentos, Mônica e o marido trabalhavam, assim como sua cunhada. O irmão, Clóvis, estava em casa, pois trabalhava como segurança particular no período da noite (e, por isso, dormia durante o dia). As crianças estavam todas no colégio. Segundo relato de Mônica, a chuva estava forte e contínua e, naquele dia, sentiu-se angustiada e aflita, mas não sabia dizer por que. Depois do trabalho, foi buscar os filhos na escola e encontrar o marido no caminho, para todos juntos seguirem para casa, como faziam de costume. Ao se aproximarem da residência, depararam-se com caos, sujeira e muitos bombeiros e funcionários da Defesa Civil. O desespero tomou conta da família que, ao olhar para os escombros, não mais reconhecia sua casa. Ao lado, a casa de Clóvis estava totalmente arruinada, e não permitia saber se ele estava a salvo ou não. Apenas após algumas horas, ao reencontrar a cunhada e os sobrinhos, teve a confirmação de que o irmão estava desaparecido e seu corpo nunca foi localizado. Como a área ainda tinha riscos de desabamento, Mônica e a família foram levadas a um abrigo temporário, onde ficaram por cerca de 20 dias. Todos os pertences dela, de seu marido e filhos foram soterrados sob o que restou de sua casa - roupas, eletrodomésticos, fotografias - e não puderam ser recuperados. Atualmente, Mônica e sua família estão morando na casa de parentes, mas ainda tentam recuperar a casa própria. 


\section{- Ariane}

Ariane tem 37 anos e trabalhava como auxiliar de banho e tosa em um Pet Shop. Nascida e criada na cidade de Teresópolis, mora com o marido, Eduardo, e as filhas de 4 e 2 anos no bairro de Vale Feliz. Seu bairro foi bastante afetado pelas tempestades, mas sua casa não sofreu grandes danos. No entanto, os arredores sofreram perdas importantes e diversos locais de uso da comunidade ficaram em ruínas, tais como praças, escolas e comércio local. Ariane relata seu choque ao ver sua congregação (Igreja Batista) completamente destruída, assim como a casa de muitos colegas da congregação. No dia das fortes chuvas, Ariane estava em casa com a família, e todos ficaram muito apreensivos, apesar de não ser a primeira vez que a cidade sofria com os efeitos das intempéries. Ao tentar falar com seus familiares, começou a preocupar-se pois soube pela irmã que seu pai, um senhor aposentado e morador do bairro Parque do Imbuí, estava em casa, incomunicável. Na manhã do dia 12, Ariane e o marido tentaram ir à casa de seu pai, mas as ruas estavam completamente interditadas, os meios de comunicação inoperantes e os profissionais que trabalhavam nos resgates não sabiam dar nenhuma informação precisa. No mesmo dia, soube por sua empregadora que o Pet Shop no qual trabalhava tinha sido completamente destruído, e desta forma estava agora sem emprego. Ariane e a família só conseguiram chegar ao Parque do Imbuí 10 dias depois das chuvas, e apesar da casa de seu pai ter sido parcialmente destruída, seu corpo nunca foi encontrado.

\section{- Luzia}

Luzia é uma mulher de 32 anos, casada há 12 anos com Lucas (desempregado), tem um casal de filhos de 11 e 09 anos e moravam no bairro de Salaquinho, em Teresópolis. Luzia conta que trabalha como empregada doméstica desde os 16 anos, quando teve que parar de estudar para ajudar a família após a morte do pai. Luzia teve uma adolescência difícil e durante anos morou com a mãe, os 5 irmãos e mais 3 primos na mesma casa, pois não tinham dinheiro para ter seu próprio lar. Quando se casou, foi morar em uma casa de aluguel com Lucas, e nos últimos 6 anos estavam comprando a casa onde moravam com a ajuda de 2 irmãos do marido. No dia das fortes chuvas, Luzia, o marido e os filhos estavam na casa de sua irmã em Rio das Ostras aproveitando o período de férias 
escolares dos filhos. Luzia e a família acompanharam as notícias pelos jornais, mas não conseguiam contato com a família. Apreensiva, Luzia decidiu voltar com Lucas para casa, deixando as crianças com a irmã na Região dos Lagos, e ao chegar à cidade, a triste constatação: sua casa não mais existia, nem nada do que havia dentro dela. Todos os seus pertences foram levados pelas chuvas. O desespero tomou conta dela de tal forma que teve que ser internada para observação após um desmaio. Apenas uma semana depois soube que uma de suas primas, Daniela, (a quem tinha como uma irmã) havia desaparecido, e ninguém sabia dizer onde ela estava no dia dos desabamentos. Esta notícia agravou o estado de saúde de Luzia, que teve que ser novamente internada para receber cuidados médicos. Hoje moram de favor na casa de uma prima dividindo um quarto para os quatro.

\section{- Bárbara}

Bárbara é uma jovem escrivã de 25 anos, casada com Marcos e mãe de uma menina de 2 anos. Ela e a família moram em Nova Friburgo desde seu nascimento, e todos residiam em localidades próximas (tendo assim todos sido atingidos em maior ou menor grau pelas chuvas na região). Seu pai e seus 3 irmãos moravam a cerca de 15 minutos de sua casa no bairro de Conselheiro Paulino, local muito atingido na época. Bárbara estava em casa com a filha quando uma vizinha apareceu em sua porta dizendo-lhe que as casas estavam desabando nas proximidades da casa de seu pai; Bárbara apressou-se para ir ao local, deixando a filha com essa colega. Quando chegou ao bairro onde residiam seu pai e irmãos, não foi autorizada pela Defesa Civil a passar pelo isolamento e demorou cerca de 12 horas para receber as primeiras informações. Após 2 dias, os corpos de suas irmãs foram localizados, mas seu pai continuou desaparecido. $\mathrm{O}$ outro irmão, que também morava com eles, sobreviveu e ficou cerca de 1 mês internado em estado grave (ele ainda em 2012 recuperava-se das lesões sofridas no desabamento da casa). Além dos familiares, muitas fotos e objetos de Bárbara ainda estavam na casa do pai, todos perdidos com o desmoronamento da encosta. 


\section{- Suely}

Suely tem 39 anos, trabalha como empregada doméstica na mesma casa há 15 anos, tem 3 filhos (19, 17 e 14 anos na época da entrevista) e é divorciada desde 2005. Ela morava com os filhos no bairro de Caleme, em Teresópolis, localidade bastante atingida pelas chuvas. No dia das fortes chuvas na região, todos estavam em casa e foram orientados pela Defesa Civil a deixar o local, pois havia riscos de desabamento. No início não queriam sair, mas assustados com a força das águas e da lama, juntaram algumas roupas e foram para a casa de uma prima. Ao chegarem lá, souberam que a casa de sua irmã tinha desabado parcialmente no bairro de Bonsucesso, e seu sobrinho de 8 anos estava desaparecido. Suely e a irmã passaram dias à procura de informações sobre o menino, mas ele nunca foi localizado. Após uma semana e ainda sob fortes chuvas, a casa de Suely não aguentou e desbarrancou junto com outras dezenas de moradias, ficando ela e os filhos apenas com o que conseguiram levar consigo na primeira noite dos temporais. Na época da entrevista, ela e os filhos ainda moravam em um abrigo temporário da Prefeitura.

\section{- Nadir}

Nadir tem 50 anos, é diarista, casada com Joaquim, caminhoneiro, e mãe de 7 filhos. Ela e a família moram no Centro de Nova Friburgo e foram completamente surpreendidos pelas chuvas na região. No dia 11 de janeiro, todos dormiam (com exceção de Joaquim, que estava em Goiânia a trabalho) quando uma parte do teto da cozinha da casa desabou; assustados, todos saíram às pressas de dentro da humilde residência. Tiveram tempo apenas de pegar alguns casacos e peças de roupa e um saco de pães, e foram em direção a parte plana do bairro, tentando encontrar abrigo em um local seguro para as crianças mais novas. Seu filho mais velho, Pedro, de 17 anos, resolveu voltar ao local para ajudar outras famílias, enquanto Nadir foi buscar ajuda com alguns amigos do bairro para cuidarem das crianças para que ela também pudesse socorrer os vizinhos. Nadir relata que naquela noite ajudou muitas pessoas, e, em alguns instantes, viu Pedro correndo para dar assistência a outras famílias, mas na manhã seguinte, soube que alguns pontos do local haviam desbarrancado com terra e escombros, e desde então não teve mais notícias de seu filho. Sua casa não cedeu com as chuvas, mas 
o perímetro foi completamente interditado e ela e os filhos até a época da entrevista estavam morando de favor na casa de sua irmã.

- Zenaide

Zenaide tem 44 anos, mora no Centro de Petrópolis, é casada com Rubens e tem 2 filhos de 15 e 12 anos. Zenaide trabalhava como vendedora em uma loja de roupas em Itaipava e o local onde mora não sofreu maiores danos. Ela estava em casa com seus filhos quando recebeu uma ligação de sua prima que, muito nervosa, disse-lhe sua tia estava desaparecida desde a tarde do dia 12 de janeiro, quando deveria ter chegado em casa após o trabalho. Como Zenaide era muito próxima desta familiar, foi ficar junto de seus parentes, apoiando nas buscas. Quando estava com as primas indo às delegacias e necrotérios improvisados na cidade, soube por uma colega que a loja onde trabalhavam havia sido atingida pelas chuvas e que todo o estoque estava destruído. Seu empregador ainda tentou salvar algumas mercadorias, mas teve que abrir falência devido ao grande prejuízo; Zenaide teve que ser demitida e só recebeu o último salário, pois não havia como seu ex-patrão lhe pagar mais. Atualmente ela está empregada novamente e sua tia, apesar dos esforços, nunca foi encontrada.

\section{- Hortência}

Hortência tem 37 anos, é mãe de uma menina de 16 anos e mora com Evandro há 5 anos; trabalha como empregada doméstica na casa de uma família de classe média alta há 10 anos. Hortência nasceu e sempre foi criada no bairro do Quitandinha, em Petrópolis, bairro onde também residiam sua mãe, avó e 2 tias. $\mathrm{Na}$ época das chuvas, todo o bairro foi bastante atingido, e sua casa, localizada em uma encosta, foi interditada pela Defesa Civil após ficar inclinada devido a um desabamento na lateral esquerda da moradia. Hortência, o marido e a filha tiveram que deixar o local pois este corria risco de ruir, e quando estavam saindo foram informados por uma vizinha que a casa de sua mãe havia sido soterrada. Hortência ficou muito abalada, e ao correr em busca de informações, caiu e bateu a cabeça, tendo sido atendida e medicada pelo Corpo de Bombeiros. Nos dias que se seguiram, tentou obter mais informações sobre seus familiares; cerca de uma semana após o início das chuvas, os corpos de suas tias foram localizados nos 
escombros, mas sua mãe e avó nunca foram localizadas. Até a data da entrevista, Hortência e a família moravam de favor na casa de seus sogros.

\section{- Olímpia}

Olímpia tem 43 anos, é casada há 21 anos com Osvaldo, encarregado de material na mesma loja em que ela trabalhava como estoquista; são pais de 4 filhos (20,17, 15 e 9 anos na época da entrevista) e moram em Nova Friburgo há 18 anos, quando vieram no interior do Piauí. Na ocasião das chuvas, Olímpia e a família estavam em casa, e seu bairro quase não foi atingido pela intempérie. No entanto, a loja onde trabalhavam e o colégio no qual seus filhos estudavam foram completamente destruídos, ficando o casal desempregado e os 4 filhos sem local para continuar os estudos. Além destas perdas, a mãe de Osvaldo, uma senhora de 72 anos, foi vista pela última vez em uma farmácia no Centro da cidade, mas nunca souberam se ela chegou a deixar o local. As suspeitas é que de que ela possa ter sido levada pela correnteza, muito forte no dia em questão. Osvaldo já havia conseguido arrumar um novo emprego mas Olímpia, em agosto de 2012, ainda estava desempregada.

\section{- Verônica}

Verônica é uma jovem de 28 anos, casada com Lúcio, cobrador de ônibus, e mãe de gêmeos de 4 anos. Trabalhava como caixa em uma loja de cosméticos no bairro de Campo Grande, em Teresópolis. No dia 12 de janeiro estava em casa com os filhos quando o marido conseguiu falar com ela pelo telefone avisando que a cidade estava toda alagada e que ela deveria ficar em casa com as crianças. No mesmo telefonema, o marido disse que tentaria ir ao bairro do Cruzeiro, onde residiam a mãe e os irmãos de Verônica. Quando Lúcio não chegou em casa no horário de costume, Verônica se preocupou, mas não conseguiu contato com o marido pois o sinal dos telefones estava muito ruim. Apenas no dia seguinte reviu Lúcio que, muito abalado, contou-lhe que a casa de sua mãe havia desaparecido, e que não havia sobrado nada no local. $\mathrm{O}$ corpo de sua mãe foi localizado 2 dias depois do ocorrido, mas sua irmã e seu irmão nunca foram encontrados. Verônica também perdeu o emprego, pois a loja onde trabalhava foi totalmente devastada. Atualmente apenas Lúcio trabalha, e Verônica ainda tenta, junto aos órgãos 
responsáveis, obter informações sobre os desaparecidos da tragédia, assim como ajuda sobreviventes que ainda passam por dificuldades nos abrigos temporários cedidos pela Prefeitura da cidade.

\section{- Tereza}

Tereza é uma mulher muito batalhadora, tem 42 anos e morava no Distrito da Posse, em Petrópolis. Trabalha como empregada doméstica; é divorciada e cria sozinha os 3 filhos (na época com 16, 13 e 10 anos). No dia 12 de janeiro, estava dormindo em sua casa quando começou a ouvir ruídos vindos da casa de uma vizinha; quando abriu a janela para olhar, viu que parte da sala e do quarto onde a colega dormia já haviam desbarrancado. Muito assustada, acordou os filhos e saiu imediatamente da casa, procurando abrigo para a família. Poucas horas depois, sua casa também não suportou e cedeu. Um de seus irmãos, Emanuel, também morador do mesmo bairro, foi ajudar os vizinhos a tirar o máximo de pertences das casas antes de abandoná-las, e segundo relato de amigos, não conseguiu sair a tempo de uma das construções. Tereza não o viu neste dia e nunca mais teve informações sobre ele. No momento da entrevista, Tereza e a família ainda residiam em um abrigo da Prefeitura.

\section{- Flávia}

Flávia é uma jovem de 33 anos, moradora de Teresópolis desde os 10 anos de idade. Seus pais morreram em um acidente de carro quando era pequena e ela foi criada pela avó materna (falecida em 2008) e por uma tia, Amélia. Atualmente Flávia é casada com Gumercindo, autônomo, e tem uma filha de 9 anos. Trabalhava como vendedora em uma loja de calçados no bairro de Paineiras, e cursava o $3^{\circ}$ ano da Faculdade de Administração em 2011. Sua tia Amélia morava no bairro de Vale Feliz, e a casa onde morava foi completamente soterrada durante a madrugada do dia 12 de janeiro. Flávia, no entanto, só soube desta notícia cerca de 1 semana depois, quando os meios de comunicação foram reestabelecidos e as ruas parcialmente desinterditadas. Além da tia desaparecida, uma de suas sobrinhas com apenas 12 anos foi encontrada morta em um córrego local, possivelmente arrastada pela correnteza. A loja onde Flávia trabalhava também foi atingida, e todo o estoque foi perdido, tendo que ser demitida junto 
com os outros três funcionários. Em 2012, Flávia já trabalhava como auxiliar em um escritório de Advocacia e o corpo de sua tia Amélia nunca foi encontrado.

\section{- Gérson}

Gérson tem 49 anos, é casado com Stella e é pai de 3 filhos (na época com 20, 17 e 14 anos); trabalha como técnico em manutenção de esteiras em uma montadora de automóveis e mora na cidade de Petrópolis desde os 20 anos de idade. Na ocasião das chuvas, Gérson e a família estavam passando férias em Águas de Lindóia, interior de São Paulo, e receberam a noticia do falecimento de sua cunhada e seus 2 sobrinhos que também residiam na cidade, no bairro de Madame Machado. Imediatamente a família de Gerson retornou a Petrópolis, e ele prontamente buscou por notícias do irmão, mas este nunca foi localizado. Como a casa do irmão fora completamente destruída, os corpos de sua cunhada e dos meninos só puderam ser reconhecidos através dos registros dentários, o que foi repetidamente referido pelo entrevistado como uma afronta à família, que segundo ele deveria ter tido o direito de fazer a identificação de seus entes queridos.

\section{- Bruno}

Bruno é um rapaz de 25 anos, casado há 2 anos com Priscila, com quem tem uma filha de 3 anos. Bruno trabalha como entregador de pizza no mesmo bairro onde mora em Nova Friburgo. Tanto sua família como a de Priscila moram no mesmo local desde que nasceram, e já haviam passado por outras situações traumáticas em decorrência das chuvas. Em janeiro de 2011, Bruno estava preso na pizzaria quando recebeu notícias de que a encosta de sua casa estava cedendo. Desesperado, correu para o local a fim de salvar sua esposa e filha. No local, Priscila já havia feito uma mala com os pertences da criança e apressava-se para sair da casa que corria riscos iminentes de desabamento. Ao olhar para o lado, o choque: Bruno logo percebeu que a casa de sua irmã já havia desbarrancado. Tentou buscar por ela, mas não teve sucesso; ela nunca foi localizada. Sua casa foi interditada pela Defesa Civil e durante um ano ele e a família tiveram que morar em um abrigo temporário da Prefeitura. Apesar do risco, eles fizeram alguns reparos e acabaram retornando para a casa onde moravam. 


\section{- Cândido}

Cândido tem 53 anos, é casado com Marilda há 34 anos e com ela tem 2 filhos adotivos (17 e 15 anos no momento da entrevista). O casal possui uma banca de jornal na qual trabalham juntos e moram há 20 anos no bairro de Olaria, em Nova Friburgo. O local onde moram foi duramente atingido pelas chuvas na região, e no dia 13 de janeiro a casa onde moravam sofreu danos irreparáveis, tendo a Defesa Civil orientado que ele e sua família saíssem do local. Marilda não queria sair da casa sem antes retirar os pertences pessoais da família, mas não havia tempo, pois a casa estava correndo risco imediato de desabamento. Foram levados a um abrigo temporário, onde permaneceram por 7 meses. Atualmente residem em uma casa de aluguel em outro bairro da cidade, e continuam trabalhando na banca de jornal que, na ocasião, sofreu apenas pequenas avarias. $\mathrm{O}$ irmão mais novo de Cândido, Pedro, morava no Distrito de Muri com a esposa e um filho de 4 anos e, pelas informações que recebeu da cunhada e dos vizinhos, ele não conseguiu sair de casa antes desta desabar na noite do dia 14 de janeiro. $\mathrm{O}$ corpo de Pedro nunca foi localizado.

\section{- Fernando}

Fernando é um rapaz de 26 anos, casado com Andreia e tem 2 filhos (na época das entrevistas tinham 5 e 2 anos). Trabalha em uma fábrica de automóveis na linha de montagem de motores e mora no Vale do Cuiabá, em Petrópolis. Fernando é da Igreja Universal do Reino de Deus desde a adolescência, local que sempre frequentou com a mãe, o padrasto e as 2 irmãs, também casadas. $\mathrm{Na}$ ocasião das chuvas, ele e a esposa receberam a visita de um colega da igreja dizendo que uma parte do teto da congregação havia desabado pouco antes do final do culto, e tanto seu padrasto como sua mãe estavam no local. As buscas duraram dias, mas apenas o corpo de seu padrasto foi localizado. A igreja teve que ser demolida para que as buscas pudessem continuar, ficando Fernando, a esposa e as irmãs sem este local de referência. A procura pelo corpo da mãe ainda fazia parte do dia a dia de Fernando em setembro de 2012, que dizia ainda ter esperança de uma posição das autoridades responsáveis sobre o paradeiro de sua genitora. 


\section{- Sérgio}

Sérgio é um bombeiro hidráulico de 49 anos, casado com Elisa há 25 anos e tem 5 filhos (20,17, 14, 12 e 9 anos na época da entrevista). No dia 11 de janeiro, Sérgio e a família dormiam tranquilamente em sua casa no bairro do Jardim Serrano, em Teresópolis, quando parte da casa começou a tremer. Assustados, Sérgio e o filho mais velho correram para tirar Elisa e as outras pessoas da casa, com medo de serem soterrados. Sérgio e os filhos homens tentaram retirar da casa o máximo de pertences pessoais da família, mas a chuva era intensa e a terra cedia rapidamente ao redor da casa, o que fazia essa manobra ser muito arriscada. Saíram com o que puderam e, na rua, dezenas de pessoas corriam em busca de lugares seguros. Na confusão, Sérgio não percebeu a ausência de Gustavo, seu filho de 12 anos. Voltou para tentar encontrá-lo, perguntou a todos que ajudavam no resgate naquela localidade, mas não teve sucesso e o menino nunca foi encontrado. Dois dias depois, a casa da família não suportou e acabou desmoronando. Até agosto de 2012 a família ainda residia em um abrigo temporário da Prefeitura.

\section{- Ronaldo}

Ronaldo tem 35 anos e mora com a esposa Laura, dona de casa, e o filho de 6 anos no bairro de Valparaíso, em Petrópolis. Ele trabalha em uma fábrica de automóveis na linha de montagem de motores. Ronaldo nasceu e sempre morou em Petrópolis, enquanto seus pais e irmãos moravam no Distrito de Itaipava, local muito atingido pelas chuvas. Na época, Ronaldo estava acompanhando as notícias pela televisão quando viu imagens do local onde sua família de origem morava e ficou preocupado ao saber a gravidade da situação. Enquanto Laura ficou em casa, Ronaldo foi em busca de informações, mas quando chegou ao local foi impedido pelo Corpo de Bombeiros devido ao alto risco de desabamentos no local. Lá encontrou um tio que lhe disse que seus pais e irmãos estavam incomunicáveis. Durante 3 dias tentaram sem sucesso ter informações, até que soube pelos jornais que os corpos de seus 2 irmãos haviam sido localizados e identificados. Seus pais, no entanto, nunca foram encontrados. 


\section{- Emerson}

Emerson tem 37 anos, é divorciado desde 2007 e tem 3 filhos (15, 13 e 5 anos na época da entrevista). Trabalha como gari em Nova Friburgo, onde mora desde os 10 anos de idade. Emerson relata ter contato com os filhos de 15 em 15 dias após um divórcio difícil com a ex-esposa. $\mathrm{Na}$ época das chuvas, Emerson estava sozinho em sua casa, no bairro de Olaria, quando percebeu que o chão de sua casa começou a abrir. Muito assustado, ele pegou sua carteira e uma foto dos filhos e saiu de casa imediatamente. Na parte plana do bairro, descobriu que muitos vizinhos já haviam saído de casa e que todas as moradias estavam correndo risco de desabamento. Ainda na mesma noite, atentou-se para o fato de que sua irmã mais velha devia estar entre as pessoas desalojadas, já que também morava no alto da encosta prestes a desabar; no entanto, não conseguiu localizá-la. Até hoje Emerson não sabe o que aconteceu com sua irmã. Algumas horas após ter deixado sua casa, a estrutura toda cedeu e nada pôde ser salvo. Emerson voltou a morar com a mãe, com quem estava até o momento da entrevista.

\section{- Osmar}

Osmar tem 51 anos, é casado com Ofélia há 15 anos e o casal tem 4 filhos (na época com 15, 12, 7 e 5 anos). Osmar trabalha como pedreiro e Ofélia como manicure. Na ocasião das chuvas, Osmar e a família, que moram no bairro do Caleme, Teresópolis, estavam em casa, dormindo, quando ouviram os gritos de alguns vizinhos anunciando que algumas casas estavam desmoronando. $\mathrm{Na}$ pressa, Osmar e a família só se preocuparam em sair da casa, sem pegar nada que havia dentro dela, nem mesmo os documentos do casal ou dos filhos. Em pouco menos de 30 minutos, todas as casas - inclusive a de Osmar - desbarrancaram junto com a encosta, não sendo possível recuperar nada que nela havia. Já na mesma noite foram para um abrigo temporário, e lá encontraram a esposa de seu irmão, Junior, que, muito abalada, lhes contou que o marido não havia retornado do trabalho. Ele nunca foi localizado. Osmar e a família passaram a morar em uma nova casa alugada, mas estavam passando por muitas dificuldades para criar os 4 filhos e sustentar a família. 


\subsection{Procedimentos de Análise}

Para realizar a análise das informações obtidas através de nossas entrevistas, utilizamos neste estudo o método de Análise de Conteúdo descrito por Bardin (2009). Esse modelo propõe que, após a coleta de dados, o pesquisador formule categorias para a sistematização das informações obtidas; estas categorias podem ser, em parte, inferidas a partir da literatura sobre o tema; porém, a fonte principal para o estabelecimento das mesmas se dá a partir do discurso dos participantes do estudo.

Os dados são reunidos segundo um significado comum (dados brutos) e, posteriormente, agrupados em categorias relativas à problemática da pesquisa, ou seja: as categorias emergem das falas dos participantes e são elencadas pelo pesquisador segundo critérios definidos tanto pela pesquisa quanto pelos próprios dados brutos que, juntos, formam uma síntese do conjunto de significados apreendidos na fase de coleta, os quais podem se aproximar de acordo com os critérios objetivos propostos para o estudo.

A fim de enriquecer nossa análise, utilizamo-nos também do conceito de testemunho apresentado por Halbwachs (1990), que propõe que todo indivíduo é testemunha de sua própria história e é através de seu discurso que nossa História é construída. Segundo o autor, o testemunho se dá a partir da transformação de lembranças em palavras e o ato de lembrar é buscar no passado essas histórias e trazê-las para o presente; no entanto, este lembrar necessita do outro, daquele que testemunha. Esse outro tem um papel fundamental não só na construção das lembranças, mas principalmente no processo de rememoração das mesmas, fortalecendo fatos, cores, cheiros e nuances - elucidando ou reforçando detalhes muitas vezes esquecidos.

Neste sentido, embora o indivíduo carregue em si suas lembranças, essas têm sempre relação com um grupo: a lembrança é construída a partir de um social, ou melhor dizendo, ela é coletiva. A lembrança, para Halbwachs (1990), é reconhecimento e reconstrução; refere-se ao sentimento de algo que já foi visto, mas também é reconstrução porque não é uma repetição estanque e determinada de acontecimentos e vivências do passado. 
Esse processo de reconstrução da memória assemelha-se a um resgate destes conteúdos no contexto dos nossos interesses presentes. A memória evocada é eleita e localizada em um tempo, espaço e conjunto de relações sociais determinados, unindo, de certa forma, passado e presente, abrindo novas possibilidades de caminhos.

Seligmann-Silva (2008), nos lembra que é imprescindível não esquecer de lembrar. O testemunho em situações catastróficas é fundamental para que, através da narrativa, o sobrevivente inicie seu processo de resignificação e restabelecimento das relações com o mundo. Este processo só é possível na relação com os outros, especialmente em casos de desastre, onde toda a comunidade sente os impactos dessa experiência traumática.

Vale apontar que, apesar de nos utilizarmos de relatos individuais, acreditamos no papel da coletividade na construção destas memórias, o que torna o discurso de cada participante parte da História na qual se insere o desastre da Região Serrana no ano de 2011. Como nos apontam Gomes e Mendonça (2002), é durante a narrativa que os tempos passado, presente e futuro se articulam. No momento em que as pessoas narram suas experiências, elas não só relatam e recontam essas vivências e os eventos que as compõem sob um olhar atual, mas também projetam expectativas para o futuro. $\mathrm{O}$ ato de narrar propicia ao sujeito novas reflexões sobre as experiências subjetivas e levam a revisões de perspectivas anteriores.

Estes relatos durante o evento em si podem, portanto, ser absolutamente terapêuticos e reinserem o sujeito nesta trama na qual é, em muitos casos, destituído de seu lugar diante do caos vivido frente a tantas perdas. É através destes ditos (e também dos não ditos) que a história de cada participante será contada, e neles estarão contidas centenas de outras histórias que foram parte daquele fatídico mês de janeiro. 


\title{
5. ANÁLISE E DISCUSSÃO DOS RESULTADOS
}

\author{
...a relação do sujeito com a linguagem $e$ a \\ história (...) é a base teórica da análise de discurso (...) \\ pela maneira particular com que ela explicita o fato de \\ que sujeito e sentido se constituem ao mesmo tempo...
}

(ORLANDI, 2007)

Este estudo tem como principal objetivo refletir acerca de uma experiência humana muito particular, em que pessoas oriundas de diferentes contextos sociais, culturais e econômicos, tiveram suas vidas atravessadas e completamente modificadas por um fenômeno em comum: todas foram expostas a vivência de múltiplas perdas concomitantes ou consecutivas e tiveram seus mundos presumidamente seguros - totalmente abalados a partir de uma situação de desastre.

A partir dos dados coletados nas entrevistas realizadas com os 20 participantes, foi possível estabelecer 6 categorias principais de análise relacionadas ao tema, nomeadas como: 1) primeiras reações às perdas; 2) desaparecimento de membro da família; 3) perdas múltiplas; 4) fatores de risco para o processo de elaboração de luto; 5) memória individual e memória coletiva; 6) rede de apoio e envolvimento da comunidade no processo de reconstrução individual e coletiva.

Estas categorias emergiram das falas dos participantes a partir dos principais pontos abordados ao longo das entrevistas, e serviram como base para a análise sobre essa vivência tão complexa de diversos lutos, tanto de uma perspectiva individual como também coletiva.

\subsection{PRIMEIRAS REAÇÕES Às PERDAS}

.. em caso de perda imprevisível, como é comum em tempos de trauma severo, quando o trabalho preparatório não pode ser feito, precipita-se um conflito transacional inevitável com grande estresse e suas sequelas.

(KLINGMAN \& COHEN, 2004) 
Nesta categoria, analisamos o comportamento inicial de nossos entrevistados frente aos eventos devastadores ocorridos especialmente entre os dias 11 e 20 de janeiro de 2011 quando chuvas torrenciais devastaram diversos bairros das cidades de Petrópolis, Teresópolis e Nova Friburgo, entre outras localidades da Região Serrana do estado do Rio de Janeiro.

Entre os participantes, encontramos pessoas que estavam presentes nos locais dos desabamentos; outras seguiam suas rotinas regulares de trabalho e estudos e somente no retorno aos lares é que tomaram conhecimento dos eventos em questão; e ainda algumas que, à distância, acompanharam o sofrimento e a angústia de familiares e amigos atingidos pela tempestade, a qual registrou a triste marca de maior desastre - classificado pelos meios de comunicação como de origem natural - do estado.

Em nosso estudo, para fins de análise, definimos que, estando ou não presentes nos locais de maior destruição no momento do desastre, todos os participantes podem ser compreendidos como sobreviventes (diretos ou indiretos) da tragédia, pois estavam expostos a um grande risco ao pertencerem às comunidades atingidas (VALENCIO ET AL., 2004).

Como discutimos anteriormente, desastres claramente são situações complexas que acarretam diferentes tipos de perdas: humanas, sociais, financeiras, dentre outras e, desta forma, as reações às perdas vividas também serão variadas e complexas. Ao longo das entrevistas, mostrou-se evidente que, para todos os participantes, a preocupação inicial foi com o bem estar físico de seus familiares mais próximos - filhos, pais e irmãos. Diante da possibilidade de perder ou ver ferido um ente querido, os participantes se preocuparam mais com a segurança de seus familiares e amigos próximos do que com a possibilidade de colocar em risco a própria vida. No relato dos participantes que estavam presentes nos locais dos desabamentos, percebemos que poucos tiveram a clareza do perigo que correram, das implicações de seus atos e o quanto suas necessidades básicas foram postas de lado em prol da segurança de terceiros:

Na hora que a gente começou a ver que a chuva tinha apertado, claro que dá uma preocupaçãozinha, mas não acha que vai estar dormindo e tudo vai começar a desabar de uma hora pra outra... todo mundo já viu aquelas chuvas bem fortes e ficou tudo bem, só as vezes falta luz, tem muito raio, essas coisas, mas de repente fica tudo muito mais confuso, né?Você pensa nas crianças, nos 
familiares que moram perto e sai buscando um jeito pra ajudar toda gente que puder... na hora você nem pensa que também pode se machucar ou até morrer, mas depois que a gente percebe isso... a vontade de achar os outros é tão grande que a gente sai correndo, nem vê onde tá pisando, sobe e desce ladeira naquela loucura, só pra ter certeza de que tá todo mundo bem, e fica daquele jeito até quando não pode mais, que tem que parar porque aí pode ficar perigoso... (Suely, 39 anos)

A gente acordou 'desbaratinado', com aquele barulho de coisa caindo e gente gritando, e você fica perdida porque na hora não sabe nem o que pegar... você sabe que não pode pegar quase nada, que tem que pegar os filhos, mas a verdade é que o pior é ver tudo caindo e não poder fazer nada... eu só imaginava o que eu ia fazer sem as crianças e aí você enxerga no escuro, anda na lama sem escorregar, faz tudo que nunca imaginou quer ia fazer... graças a Deus eu tive força pra tirar meus filhos antes que acontecesse alguma coisa com eles! O triste mesmo é que não dá pra fazer mais nada porque passa muito depressa tudo isso e mesmo que você pense em um montão de coisa que quer pegar e no monte de gente lá, não tem mais tempo pra isso... (Tereza, 42 anos)

O susto é grande, mas os filhos vêm em primeiro lugar, sabe? Não tinha dúvida que se tivesse que ficar lá pra eles poderem sair eu ficava! Não tem nem como pensar em fome, sono, calor, frio, só pensa mesmo nas crianças, na mulher e na família que tá lá passando dificuldade também. Quando vê todo mundo fora e bem é que você volta a respirar mais aliviado, mas até todo mundo estar em lugar coberto, protegido, ainda demora, e até lá você fica preocupado pra que nada de ruim aconteça pra eles. Eu sei que é imprudente da parte da gente fazer as coisas como se fosse um garoto novo, e nem percebe que está correndo risco na hora mesmo do pior, mas o que você vê mesmo é as pessoas precisando de ajuda e não pode simplesmente sair sem ajudar, é coisa que a gente só sabe quando está lá, vendo aquela confusão... (Osmar, 51 anos)

Ficou evidente que o desejo de proteger os filhos e demais membros da família superou o medo de sofrer alguma lesão ou até mesmo de perder a própria vida, corroborando com Ripley (2008) quando esta afirma que, em situações de desastre, é comum que algumas pessoas adotem o que ela denomina como atitude heroica, ou seja, em detrimento de sua própria segurança, o indivíduo se coloca em risco em função de terceiros - estes gestos estão mais comumente relacionados a pessoas caras ao sujeito, mas este comportamento pode surgir também na tentativa de salvamento de pessoas, animais ou até mesmo objetos que lhe sejam totalmente desconhecidos, como podemos identificar em alguns relatos:

Na hora que começou a apertar a chuva, eu olhei pro lado e vi uma senhora gritando pelo cachorrinho dela que tinha ficado dentro da casa, e na hora não pensei duas vezes: corri subida acima e fui pegar o bichano... claro que eu sei que 
a casa dela tava pra cair, que era uma loucura ficar indo e voltando naquele barro todo e a chuva não parava, mas a senhora chorava tanto... pra ela, ela tava perdendo uma pessoa da família, né? Eu sabia que podia ajudar, e graças a Deus consegui resgatar o cachorrinho, todo molhado, tadinho... e ela chorava e me abraçava, tava toda emocionada... pra você ver como vale a pena a gente ajudar... (Emerson, 37 anos)

Olha como são as coisas: depois que você sai de casa, começa a ver que tem vizinho correndo com sacola na mão, criança no colo e não tá conseguindo nem se equilibrar direito, e de pronto você estende a mão e oferece ajuda, claro! Eu que não ia ficar de braço cruzado sabendo que meus filhos já estavam todos lá embaixo e não ia dar uma força pro pessoal que ainda tinha que descer, é aquela coisa de momento, você simplesmente sabe que precisa ajudar... não tem medo nessas horas, tem vontade de ajudar, de ser parceira das pessoas, porque todo mundo é irmão, na verdade... quem sabe se não posso ser eu precisando de ajuda? Vou querer ser ajudada também! Uma mão lava a outra, e eu sempre vou fazer minha parte, até porque eu quero ficar com a minha consciência tranquila... (Tereza, 42 anos)

Eu tava muito nervosa naquele dia porque nunca que você quer sair da sua casa e deixar suas coisas e ver tudo caindo é muito difícil... mas não é por isso que a gente não olha pra pessoa do lado e ajuda com o que pode... eu tentei fizer de tudo um pouquinho, de levar criança pra baixo até pegar na mão dos mais idosos e levar pra um lugar coberto, mais protegido, porque ali tava tudo muito perigoso e a chuva não parava por nada nesse mundo... a gente tava cheio de lama, sujo de tudo, suado, mas nessas horas você arruma fôlego pra tudo e ajuda quem estiver ali do seu lado pedindo, não importa quem é... eu sei que a situação não tava fácil pra mim, mas tinha muitas pessoas machucadas, assustadas e que eu ajudei a tirar dali, e isso foi muito bom pro nosso coração... (Nadir, 50 anos).

Mesmo sendo apontado como um comportamento pouco adaptativo, notamos em nossos entrevistados (especialmente nos que estavam presentes nos locais atingidos pelas chuvas da região) que a resposta de tentar salvar familiares e amigos foi a mais frequente, assim como muitos ajudaram pessoas desconhecidas a se abrigar e receber apoio de saúde nos postos de atendimento disponíveis. Este desejo de ser útil e de participar dos resgates parece estar diretamente relacionado ao sentimento de pertencimento que a família e a comunidade proporcionam a seus membros e a importância dos papéis exercidos por cada indivíduo em seu ciclo familiar e na sociedade, lembrando que só exercemos um papel no grupo se nosso correspondente também existir (como, por exemplo, os papeis de pai/mãe só existem na relação com os filhos e vice-versa). 
Entre nossos entrevistados tivemos exemplos de sobreviventes que não só ajudaram seus familiares a se salvarem, mas também auxiliaram vizinhos ou até mesmo desconhecidos a encontrar abrigo, independente destas ações colocarem suas vidas em um novo risco. Isto reforça o que já havia apontado Valencio et al. (2005) quando os autores nos afirmam que, em momentos do desastre, é frequente que o indivíduo exposto à situação catastrófica perceba mais intensamente o outro do que a si mesmo e sua preocupação aumenta na medida em que percebe que o bem estar alheio está comprometido. Para nossos participantes, a possibilidade de estarem correndo risco de vida não superou o desejo de prestarem assistência aos pares, pessoas que também perderam algo e/ou alguém.

No relato dos entrevistados, sabemos que estes também perceberam que este sentimento era algo recíproco e compartilhado na comunidade, já que muitos outros sobreviventes formaram grupos de apoio e resgate:

As pessoas foram muito solidárias, queriam ajudar quem estava com mais dificuldade, mas no final estavam ajudando todo mundo. Na hora a gente não sabe o que é de quem, só sabe que se está ali e de alguém que você conhece porque, no final das contas, todo mundo se conhecia, um pouco mais ou um pouco menos... $e$ ajudar também ajuda a gente a sentir que está fazendo alguma coisa pelo próximo, eu sei que era perigoso, mas na hora o que vale é fazer o que dá, não importa pra quem... era todo mundo ali junto, o que um podia ajudar o outro precisava de ajuda... era uma coisa de cortar o coração, muito bonito de ver mas muito triste pela situação... (Nadir, 50 anos)

Eu não perdi minha casa, mas tanta gente perdeu que o mínimo que eu podia fazer era dar uma assistência pro pessoal lá do bairro... a parte mais alta ficou bem ruim, e as pessoas estavam muito nervosas... quando você sabe que pode ajudar, tem mais é que colocar a mão na massa e ajudar porque já tinha muito sofrimento ali pra gente só ficar de plateia, né? Cadê a solidariedade? Por isso fui lá e tentei fazer minha parte, até porque eu não perdi minha casa, mas todo mundo perdeu alguma coisa ali naquelas semanas. Eu e muitos outros fizemos o que tava dentro do nosso alcance pra poder diminuir as dificuldades que as pessoas tavam passando, e isso é o certo mesmo, um grupo de pessoas tem que ser unido, ainda mais num momento como esse... (Ronaldo, 35 anos)

A gente tenta primeiro tirar a família do perigo, mas quando olha aquele mundo de gente precisando, o que você pode fazer? Ajuda no que pode! Claro que eu sei que tenho uma esposa e filha pra cuidar, mas as outras pessoas também tem gente que ama ali, sabe lá se machucada ou até morrendo, né? Aí você meio que esquece que tem perigo e vai ajudando, mas nem dá pra fazer muito porque o terreno todo instável e pouca luz, muito barulho, você fica confuso... mas eu tentei e todo mundo que tava ali tentou também... O importante nessa hora é você fazer sua parte porque teve gente ali que perdeu tudo, tudo mesmo, e dói ver tudo aquilo 
indo embora sem você poder segurar... se eu podia pegar uma coisinha aqui e ali, não tinha como virar as costas e ir embora... tinha um montão de homens ajudando a pegar as coisas das casas pra tentar salvar, mulher correndo com criança pequena no colo, é o mínimo que a gente pode fazer pra ficar menos pior do que já está... (Bruno, 25 anos).

A solidariedade e a empatia são sentimentos comuns em situações de desastre, especialmente nos primeiros momentos que se sucedem a tragédia (VALERO ET AL., 2004), o que pudemos verificar em nossos relatos. Mesmo que cada indivíduo possua formas particulares para lidar com suas perdas e, no momento em que se depara com a realidade da ausência do(s) objeto(s) de amor, tenha que buscar em seu repertório respostas que se adaptem as suas necessidades (PARKES, 2009), ajudar ao próximo diante do caos dos desabamentos e desbarrancamentos se deu de forma natural e espontânea, o que nos aponta que, em uma situação de desastre, nossas necessidades individuais e as da coletividade parecem formar um sentimento único, fazendo sobressair comportamentos repletos de compaixão e companheirismo.

No entanto, apesar de terem participado do processo de retirada de pessoas desabrigadas e feridas dos locais - ou quando apoiaram os voluntários nos abrigos temporários - o sentimento de impotência ainda foi um dos mais citados pelos entrevistados. Muitos acreditam que a ajuda oferecida foi aquém do necessário diante da quantidade de pessoas feridas, desalojadas e desabrigadas e, quanto mais atuavam nos locais, mais percebiam que centenas padeceriam naquele desastre:

Você ajuda aqui, ajuda ali, mas quando vai ver, pra cada um que chegou no abrigo tinha uns dez machucados ou sumidos... como a gente pode fazer mais sendo uma só? Eu queria subir, pegar um montão de gente nas costas e levar pra baixo, mas a gente também não sabe como tudo escorrega, tava de noite, muita gente gritando e você não sabe como pode ajudar mais... e tem sempre alguém que precisa, e você também sabe o que precisa, fica aquela confusão e você não tem noção de quanta gente precisa, é um mundo de gente correndo... é assim, querendo ter mil braços e pernas! Eu sei que eu fiz muita coisa, mas quanto mais gente morria, mais eu ficava desesperada porque não tinha como fazer mais... é um sentimento muito ruim esse de você estar lá, ajudando, mas saber que mesmo assim tem um mundo de gente que não vai conseguir sair bem dessa situação... (Mônica, 42 anos)

Quando você acha que está ajudando, vê aquele monte de gente machucada com lama dos pés a cabeça e vê que tem tanta gente pra ajudar ainda... mas tem como fazer diferente? Não dá pra deixar a família sozinha, mas também quer 
ajudar os outros que estão lá ainda... pra casa buscar as coisas não dava mais pra voltar, mas podia ir ajudar o pessoal no pé da ladeira, mas é difícil quando a gente não é mais moleque...eu sempre penso nas coisas que a gente fez naquele dia, mas ainda assim tanta gente morreu, tanta gente perdeu casa, carro, móveis que a gente não conseguiu pegar, até bicho de estimação ficou pra trás... é uma encruzilhada, a gente quer fazer mais mas também não tem mais tanta força assim, nem pode esquecer que tem família...eu sabia que a hora tava passando e não parava de chover e, por isso, muita gente ainda tava lá tentando pegar as coisas, mas tem uma hora que seu corpo também não aguenta mais subir e descer, ficar de pé já é um custo e as pernas não acompanham... por mais que você tente, tem uma hora que não dá mais, mas desistir é horrível... (Cândido, 53 anos)

Teve uma hora que eu estava tão cansado que não sabia mais nem pra onde andar, o que fazer com o que eu estava conseguindo retirar das casas, mas tinha que continuar fazendo... aí olhei pro lado e vi uma casa caindo encosta abaixo e entendi que tudo aquilo era muito maior do que a gente podia fazer e bate aquele desânimo, mas também se você não faz, muita coisa que foi recuperada teria ficado por lá... dá vontade de ser um polvo com aqueles milhões de braços pra poder pegar tudo e salvar, mas não teve como... a gente ficou lá a noite toda ajudando e no dia seguinte já sabia que tinha morrido pelo menos umas 100 pessoas, aí dói... mesmo você fazendo tudo aquilo, ficando a noite toda embaixo de chuva e lama, tinha aquele monte de gente morta porque não teve tempo de sair e ninguém conseguiu ajudar a tempo... é uma sensação de perder as forças, de querer muito fazer mais mas não ter condição mesmo... (Ronaldo, 35 anos)

Os participantes apontaram ao longo das entrevistas uma série de variáveis que interferiram no apoio prestado aos outros moradores no momento do desastre, tais como dificuldades de acesso aos locais atingidos, limitações da idade ou a falta de conhecimento em técnicas de resgate e transporte de feridos. Apesar de cientes de suas limitações, ficaram evidentes sentimentos de desalento, culpa e menos-valia em suas falas:

Eu bem queria ajudar, mas tem horas que você sabe que se pegar uma pessoa machucada do jeito errado, ela pode morrer, né? Eu não posso fazer isso, tem que deixar pra quem sabe... na hora você olha pro lado, procura os bombeiros, mas no começo ainda não tinha chegado ninguém... aí você olha aquela pessoa do seu lado gemendo de dor, aí não sabe como pegar nela e fica como então? Dá uma agonia, o peito fica apertado, mas não tinha como, eu não tenho os conhecimentos... imagina ter alguém morrendo porque você fez errado? Você ali, sem saber, quebra um pescoço ou deixa a pessoa paralítica? Eu já tava numa coisa de não poder ajudar mais, se alguém morre nos meus braços eu era capaz de ir junto, Deus me perdoe... (Tereza, 42 anos)

A gente sempre quer fazer mais, pegar mais coisa, subir e descer com gente, geladeira, roupa, fogão, sair até com a casa das pessoas se desse, o que pudesse 
colocar nas costas pra poder ajudar os outros, mas quem disse que tem força pra isso? Eu trabalho desde os meus 14 anos de idade, mas não tem como eu fazer o que eu fazia 20, 30 anos atrás! Eu era super ativa e via aquele monte de rapaz ajudando, gritando, correndo, subindo e descendo, e eu queria fazer igual, mas quem disse que o corpo ajuda? É muito difícil envelhecer, minha filha... as pernas não aguentam mais tanto sobe e desce, os braços não suportam o mesmo peso de antes, a cabeça está mais confusa, a gente não tem mais a mesma vista, os olhos já estão cansados... não tem mais aquele vigor da juventude não... muito triste mesmo... (Nadir, 50 anos)

Na hora que eu cheguei lá, eu tava procurando meu pai e meus irmãos, mas aí você vê aquele monte de gente ali, gritando, chorando, pedindo ajuda e você quer ajudar! As pessoas mais velhas implorando pra gente ir buscar gato, cachorro, crianças, tudo que tinha ficado lá pra cima e a gente não podendo passar, foi muito difícil... tudo interditado, as passagens sem acesso, árvore caída, poste, tudo mal iluminado, as ruas não passava nada nem ninguém...chovia tanto que não dava pra ver um palmo na frente do nariz, mas mesmo assim você está disposta a fazer o que for necessário... mas como não podia passar, tinha que ficar atrás do cordão de isolamento, a gente só ajudava ali embaixo mesmo... eu fui comprar água e biscoito pras crianças, peguei roupa de doação, cobertor pra diminuir o frio, mas mais do que isso tava impossivel naquela hora... (Bárbara, 25 anos)

Devemos lembrar que as pessoas afetadas por um desastre precisam de tempo para assimilar não só a devastação externa a si, mas também a desorganização interna causada pela catástrofe em suas vidas, o que não foi diferente para nossos participantes. Isso se dá especialmente porque quaisquer acontecimentos que provoquem mudanças intensas em nossas vidas especialmente quando são eventos totalmente inesperados - desafiam o que acreditamos ser nosso mundo presumido, levando inevitavelmente a uma crise, e os indivíduos podem se apresentar inquietos, tensos, ansiosos e até mesmo indecisos até que a readaptação seja concluída (CASELATTO, 2005).

Imagens intrusivas da cena caótica onde ocorreram as perdas também são frequentes em sobreviventes de desastres, e podem ser relatadas mesmo nos casos em que o enlutado estava ausente quando estas aconteceram (KRISTENSEN \& FRANCO, 2011), fenômeno este que ocorreu com alguns de nossos entrevistados. O já referido sentimento de impotência exacerbou reações ansiosas e a ocorrência de imagens recorrentes dos eventos ocorridos na região, deixando marcas em todos os participantes. 
Porém, é na fala dos que não estavam presentes nos locais dos desabamentos que este sintoma ficou mais evidente, aliado justamente à culpa por essa ausência:

Eu vendo tudo aquilo de longe, sem poder estar na minha casinha, sem saber como estava minha família, meus amigos, meus vizinhos... quando a gente está perto, a gente pode dar aquela força, ajuda um o outro... eu devia estar em casa pra fazer alguma coisa... será que não dava pra salvar alguma coisinha? Você pensa... Quando eu cheguei lá, já não tinha mais nada (choro), minha casa já não tinha mais nada, nem uma parede! Mas o pior é que não tinha a minha nem a dos meus vizinhos e nem de ninguém ali do bairro... e eu não tava lá pra ajudar ninguém! E os vizinhos que morreram ou sumiram? A gente podia ter ajudado os mais velhinhos, sei lá... fica uma dívida com os outros, como se a gente tivesse fugido da morte e ficado longe das pessoas queridas ali do bairro (...) muito triste pensar isso... (Luzia, 32 anos)

Eu sabia que tinha alguma coisa errada, eu tava agoniada, e tentei chegar na casa do meu pai mas ninguém me deixava passar! Aí você quer fazer, mas não pode, e eu não podia deixar a minha pequena sozinha a vida toda, mas quando me falaram que tinham achado minhas irmãs mortas e meu irmão tava no hospital, eu sabia que devia estar lá com eles (choro). Eu casei muito nova, saí logo de casa, e meus irmãos estavam lá, todos cuidando do meu pai, e eu não pude fazer nada pra ajudar eles... eu devia visitar mais, ligar mais, desde que eu saí de casa só penso mais no marido e na minha casa que agora, não adianta, não posso mais ter meus irmãos por perto e meu paizinho não dá nem pra falar... ah, como faz falta a família da gente (choro). Eu fico sempre pensando em tudo que aconteceu, lembrando das coisas que a gente viu lá nos bairros e na televisão, até hoje eu sonho com isso, é uma cena que não dá pra esquecer... (Bárbara, 25 anos)

Eu sempre ia pra Igreja às terças, quintas e domingos, e naquele dia eu estava preocupado porque minha menina menor tava com febre e eu resolvi ir pra casa... justo quando, né? Toda estrutura caiu, tudo foi pro chão e eu estava seguro na minha casa enquanto minha mãe e meu pai lá... a gente tenta entender porque, em qualquer dia, eu deveria estar lá,e bem naquele dia, bem naquele dia mesmo, eu fiquei em casa... mão de Deus? Pode ter certeza, mas e depois, quando quer ajudar ninguém deixa? E eu me sentia inútil olhando tudo aquilo no chão e não podendo fazer nada... lembrava toda hora dessa cena, de tudo que a gente viveu naqueles dias... não sai da cabeça da gente, sempre, toda hora, de dia e de noite... pra que ficar se não pode estender a mão pros outros? E quantas vidas a gente poderia salvar se estivesse lá? Eu sou jovem, poderia ter ajudado mais os mais velhos, eu sei disso... (Fernando, 26 anos)

A ausência no local dos desabamentos é percebida pelos entrevistados como um fator contribuinte para as perdas vividas, de modo que alguns creem, inclusive, que sua presença poderia ter mudado o curso dos eventos. Esta 
concepção quase "mágica" de que poderiam ter um maior controle sobre o caos se estivessem fisicamente presentes aumentou a ansiedade e gerou sentimentos conflitantes em relação aos acontecimentos da época, dentre os quais destacamos tristeza, remorso, mágoa, procura de significado, desesperança, ressentimento e dor, confirmando os achados de Kristensen e Franco (2011) sobre a chamada culpa do sobrevivente.

Em um desastre, a probabilidade de ocorrerem mortes múltiplas é maior, e estas são, em geral, muito traumáticas (PARKES, 2009); uma particularidade destes eventos é que, em situações catastróficas, são possíveis diversas mortes entre membros de uma mesma família. Um dos sentimentos mais presentes na fala de nossos entrevistados foi justamente o medo de perder entes queridos. Este temor tornava-se mais concreto a cada telefonema que não se completava, ao ver cada vizinho que chorava por um familiar não localizado, pelo rosto cansado dos profissionais do Corpo de Bombeiros e da Defesa Civil:

No começo a gente só ficava pensando assim: 'Todo mundo tem que estar bem (...) meu pai, minha mãe, meus irmãos (...) mas o celular não dá sinal, o orelhão da esquina tá quebrado, ninguém consegue falar com ninguém e você nem consegue raciocinar direito, só quer ter notícia! Fica se perguntando se o pessoal da prefeitura não quer consertar as linhas, se não sabe que todo mundo está desesperado, se os bombeiros não querem ajudar logo a liberar as áreas de risco, sei lá... parece que ninguém percebe que a gente precisa de notícia porque ficar sem saber é pior do que saber logo! Imagina se, de uma hora pra outra, você perde todo mundo que você ama? Eu não conseguia nem imaginar a dor que ia ser se a minha família tivesse toda morrido ali, e eu viva... a gente nessas horas prefere até morrer do que perder a família! (Verônica, 28 anos)

E a preocupação com os outros? Demais! Eu sabia das minhas crianças, mas cadê que eu sabia dos meus parentes? Ninguém sabia dizer nada, a gente não conseguia ligar pra ninguém, aí vai batendo aquele desespero e nada consola a gente (...) quem garante que tá todo mundo bem quando você não consegue uma informação e vê todo mundo naquele nervoso todo (...) tanta gente machucada, morrendo que você só pensa no pior...mesmo quando a gente quer acreditar que não vai acontecer nada com ninguém próximo, você lembra que, de verdade, ali todo mundo tava perdendo alguém, e como você escapa de uma coisa que leva um aqui, outro ali... é um desespero de todos os lados, por você e pelos outros...os bombeiros tudo cansado, com cara de desânimo pra cada vez que achavam o corpo de alguém, e quem tava ali só queria saber de quem era porque podia ser alguém da família ou vizinho que a gente conhecia há tantos anos... é aquela coisa de ver que cada pessoa ali podia ser da sua família... (Ronaldo, 35 anos) 
Pra todo lugar que você olhava, tinha gente cheia de lama, o rosto cansado, todo mundo mesmo... os bombeiros estavam trabalhando muito, mas você via que eles também iam desistindo... mas não é o tipo de coisa que possa desistir, né? Sabendo que alguém pode estar embaixo da terra, só pode continuar, e quando a gente via que eles estavam saindo de lá, já achava que eles iam desistir, e isso dói na gente, porque aonde estão os nossos familiares? Fica sem saber se sente dó do bombeiro ou se quer que ele continue sem parar até achar! Eu sei que tem horas que não pode mexer na terra porque ia cair mais, mas a gente tava sem telefone, sem comunicação, só podia ter notícia com ajuda do pessoal dos Bombeiros mesmo, e esperando eles encontrarem mais alguém vivo no meio daquela terra toda e torcendo pra não ser um conhecido ou um parente... depois começa a torcer pra achar, vivo ou morto, mas achar! (Zenaide, 44 anos)

Além do medo e da angústia frente à possibilidade de morte de pessoas queridas, devemos considerar o fato de muitos de nossos participantes terem ficado expostos a pessoas gravemente feridas e até mesmo cadáveres, o que em si já é altamente impactante. Estas cenas trazem à tona a temática da fragilidade da vida (própria e do outro) e da imprevisibilidade do futuro, exacerbando sentimentos como insegurança, impotência e tristeza:

Eu nunca tinha visto uma pessoa morta assim, na hora, na minha frente... é horrível você perceber que logo antes a pessoa estava bem e viva e aí, logo depois, morreu (choro). Os olhos perdem a cor, a pele toda enrugada por causa da chuva, muita lama na roupa, de uma hora pra outra... aí você fica pensando de que vale tudo isso, se trabalha hoje mas amanhã não sabe nem se vai estar vivo? Horrível, o corpo fica todo inchado, a gente olha, mas nem reconhece as pessoas, e depois fica sabendo quem era e fica mais assustado ainda de como muda tudo...não é que eu tenho medo de gente morta, mas tem coisa que a gente prefere guardar na memória da pessoa sorrindo, cantando, alegre, e aí quando vê desse jeito, a imagem não quer sair da cabeça... e deve sofrer nesse tipo de morte, eu acho... eu queria que não, mas não sei se tem como não... (Hortência, 37 anos)

Por mais que você saiba que as pessoas estão mortas, quando você vê já tá no caixão, limpinho, arrumado, pronto pra ser enterrado... lá não, era corpo boiando nos córregos, criança que estava dormindo no berço, uma tristeza de cortar o coração... e o pior é que naquela confusão, um monte de gente ainda pisou em cima do corpo das outras, passou por cima, até pode ter empurrado mais pra baixo dos escombros porque na hora de fugir é isso que acontece... você imagina que, pra se salvar, vai passar pelo corpo de outra pessoa? Quem pode ver as coisas igual depois disso? Não dá! Ainda mais quando você sabe que era gente que morava ai, na casa do lado da sua ou na outra esquina...eu fico pensando nisso sempre que lembro desses dias porque a gente não imagina quanta gente morreu ali e que a gente não viu mais, que ficou debaixo daquilo tudo ou que você viu e nem sabia que era a pessoa... só dá pra ter certeza da morte mesmo nessa vida... (Sérgio, 49 anos) 
Desde o primeiro dia eu fui ajudar a procurar minha família, e lá no terreno da Igreja tinha muita gente soterrada, muita mesmo... gente que eu via toda semana no culto, meus irmãos... gente machucada, gente morta, gente sem nada, nem roupa pra colocar no corpo... tudo que minha congregação demorou anos pra erguer ali, no chão, e meus irmãos debaixo de toda aquela terra...o corpo é só uma casca, mas é essa casca que a gente vê todos os dias, que a gente lembra nas fotos, que celebra os aniversários, e quando morre assim essa casca quebra e a gente se impressiona com esse aspecto feio que a morte trouxe pras pessoas nesse momento de agonia do final dos dias... eu sei que não tem que ficar lamentando a morte que veio das mãos de Deus, mas a gente chora, fazer o que? Fica sem saber o rumo pra recomeçar... (Fernando, 26 anos)

Para muitos, ter a experiência de ver cadáveres pode ser perturbador, especialmente nos casos de morte abrupta e violenta, nos quais é comum que os corpos sejam mutilados, dilacerados e desfigurados. Dentre nossos entrevistados, o choque diante desta realidade caótica e repleta de tragédias familiares foi tão intenso que não foi possível processar todos os acontecimentos durante alguns dias, sendo preciso pedir ajuda a outras pessoas para poder "montar o quebracabeça":

Na hora você perde o rumo, fica perdido, e eu até hoje não lembro das coisas, foi mais dos vizinhos que eu fiquei sabendo... eu lembro mais de querer sair correndo de lá com medo da casa cair na cabeça da gente, mas o que eu falei, quem me ajudou, que horas era, não lembro de nada. As pessoas acham que é coisa que a gente não esquece, mas na hora acontece tanta coisa que não consegue nem é lembrar direito depois... eu só sei que é muita coisa, muita gente, muito barulho, muita preocupação, e só porque com os outros falando é que você consegue lembrar mais certinho das coisas...fica tudo uma confusão e tem horas que a gente acha que lembra, mas precisa confirmar com os outros porque é uma mistura de lembranças que você nem sabe se aquilo aconteceu mesmo... (Osmar, 51 anos)

Eu só lembro que a hora que eu vi a casa toda no chão, eu perdi o chão também e de repente tudo apagou... desmaiei no meio de toda aquela sujeira e só fui acordar um dia depois, sem saber se era um pesadelo ou se tinha acontecido mesmo... mas até você entender leva tempo porque um dia tem tudo no outro não tem nada, aí é ruim da gente aceitar. Eu que desmaiei então, não tem nem como lembrar, mas o pior pra mim é que nem antes de desmaiar eu lembrava, nadinha! Falando com uma vizinha que eu fui trazendo de volta na cabeça umas coisas, mas também é do jeito que te contam ou não sabe se o que você lembra aconteceu...as pessoas que lembram é que ajudam a lembrar, e eu ainda fiquei um tempão sem saber de nada, aí o jeito é perguntar pros outros mesmo... (Luzia, 32 anos) 
Eu fiquei tão nervosa que sai correndo assim, sem nem olhar pra baixo... quando vi, estava escorregando e não lembro de mais nada depois disso... quando acordei, já estava no hospital sendo atendida... aí ainda fiquei no hospital mais um tempo em observação e aí que as pessoas começaram a me contar tudo que tinha acontecido... parece um pesadelo, daqueles horrorosos, que você sente que tá caindo? Não dá pra acreditar na hora, só depois que você começa a ver que é aquilo mesmo e desespera, e como! Pensa no desespero, eu no hospital, querendo estar com as pessoas e nem lembrando se elas estavam comigo ou se tinham ficado lá no bairro, ou se eu já sabia onde elas tavam e eu que não lembrava... fica nervosa e desmemoriada, aí é que fica pior de vez... (Hortência, 37 anos)

Após o choque inicial, além desse sentimento de incompletude diante da vivência traumática, alguns participantes relataram também sintomas físicos que se intensificaram frente à constatação das perdas. Dentre estes, podemos citar choro incontrolável, dores de cabeça, desmaios, crises de gastrite e dores generalizadas (peito, garganta, pernas), além de cansaço, alterações na alimentação e no sono, angústia e tremores relacionados ao medo do perigo:

Tudo doía, eu não sabia nem o que eu tava sentindo... minha cabeça parecia que ia explodir e eu mal conseguia falar... mas também, falar o que nessas horas? Não tinha chão, tava tudo muito confuso, as pernas pesadas, não conseguia nem andar direito, e pra piorar você fica fraco porque não come nem dorme, e só lembra dessas coisas quando já passou uns 3 dias porque começa a ficar zonzo... Eu lembro que eu sentia meus braços formigando de tanto fazer força, e depois de uns dias eu não conseguia nem levantar direito pra passar xampu na cabeça... pra você ver como eu tava cansado, eu só queria dormir e dormir, e eu sou daqueles que fica acordado a noite inteira assistindo televisão! (Emerson, 37 anos)

Eu só chorava, misturava com a chuva e não parava, até hoje a gente sente aquele aperto no peito, um sentimento ruim de quando a gente não pode fazer muita coisa? A pressão vai no teto e o coração fica disparado um tempão... eu sentia um aperto no peito daqueles que parece que o coração vai pular pra fora do corpo, não dá pra explicar o que acontece, só dá vontade de gritar, correr mas nem isso dá pra fazer porque precisa cuidar dos meninos, de quem tá precisando de você naquela hora... engole o choro e vida que segue... (Tereza, 42 anos)

Eu comecei a sentir o estômago embrulhando, uma vontade de vomitar, zonzeira, achei que ia cair durinha no chão de tanta agonia! Quando eu olhei e vi que minha casa tinha ido toda no chão, eu não conseguia nem ficar de pé direito... o corpo começa a pedir pra parar, você não pode sentar que tudo gira, se ficar de pé a perna tá bamba e se deitar é capaz de não levantar mais... olhei pras crianças e tive que melhorar, tava todo mundo ali, mas na hora tudo dentro de mim virou de ponta cabeça... um nó na garganta, fiquei mal mesmo! Eu fiquei com um gosto muito ruim na boca, uma dor de cabeça daquelas que a gente só quer deitar no quarto escuro e esquecer que tem qualquer compromisso, que até o barulho do alfinete parece que é um trovão... (Mônica, 42 anos) 
No entanto, mesmo apresentando uma série de desconfortos e outros sintomas físicos, percebemos que nossos participantes logo procuraram se reorganizar para retomar o controle da situação, principalmente por causa dos filhos que, menores e dependentes, precisavam naquele momento que os adultos e responsáveis lhes proporcionassem segurança e bem estar. Essa desorganização causada por uma situação de desastre já havia sido relatada por Valencio (2005), assim como a constatação de que a presença de outros sobreviventes considerados mais frágeis pode levar o sujeito não só a relegar seu bem estar e segurança, mas também a apresentar esses sintomas físicos como a única forma de expressar a dor e a desestruturação que não conseguem (ou sequer podem) nomear em palavras.

Como já referido anteriormente, diversos autores (VALENCIO ET AL., 2004; SELIGMANN-SILVA, 2008) acreditam que situações traumáticas podem ocasionar períodos de completo esquecimento dos eventos vividos como uma espécie de blackout que visa proteger o indivíduo de uma maior desestruturação diante de todas as perdas - às quais precisará se adaptar gradualmente - e podemos perceber que, entre nossos entrevistados, este fenômeno se deu de forma bastante clara, especialmente nos primeiros dias após o início das chuvas na região:

Eu tentava lembrar de algumas coisas mas não tinha como! Sabe aquela última pessoa que você viu antes de sair de casa correndo ou aquela hora que você sabe que alguém pegou na sua mão pra ajudar a descer um barranco, mas você não consegue se lembrar quem foi? E não adianta, até hoje eu tento, mas não consigo... eu sinto que tem muita coisa que eu quero esquecer, mas mesmo quando eu quero lembrar não dá, e eu queria tanto agradecer algumas pessoas, sei lá, lembrar só um pouco mais de coisas... a memória da gente não vem, e tem coisas que eu nem quero mesmo lembrar, prefiro deixar lá naqueles dias, enterrado com as pessoas que morreram na chuva... é feio dizer isso, mas tem muita dor nessa história... (Suely, 39 anos)

Tem horas que eu tenho certeza de que liguei pro meu irmão uma hora antes de saber que ele tinha sumido, mas depois já não tenho certeza... depois tem aquela hora que você quer muito lembrar com quem falou no dia das buscas, mas só consegue lembrar da cara e nunca do nome... aí vem gente dizer que te viu na porta do abrigo e você simplesmente não acredita porque tem certeza que aquele dia não estava lá... não sei se é cansaço, se é tristeza, mas a memória da gente vai embora nessas horas... eu sei que o cansaço também pode deixar as lembranças meio misturadas, mas como pode a gente esquecer do rosto de algumas pessoas, das conversas que teve com o pessoal dos lugares que você esteve, de muita coisa que na hora era super importante? Eu tenho um montão de lembranças, mas tem também um montão de brancos nas histórias... (Gérson, 49 anos) 
É impressionante, mas acredita que tem coisas que eu não lembro? É como se uns dias não tivessem acontecido! Eu fui um dia na delegacia falar com o policial que tava ajudando nas buscas, e ele tava na minha frente e disse que a gente já tinha conversado sobre aquilo uns dois dias antes e eu não lembrava nem de ter ido lá... tanta gente, tanta coisa acontecendo que a gente se perde no tempo e nos lugares... eu acho que a gente vai ficando mais cansada também, com muita gente dando informação misturada, depois você fala com mil pessoas diferentes sobre o mesmo assunto e como a resposta é a mesma, você até se esquece do que e de quem te disse aquilo...mas também, lembrar pra que? Tem coisas que as vezes é melhor nem lembrar de verdade... (Luzia, 32 anos)

Podemos afirmar, a partir dos aspectos analisados, que os momentos iniciais após o desastre na Região Serrana levaram a um nível intenso de desorganização e suscitaram sentimentos de medo, angústia, culpa, impotência e desamparo em nossos participantes, estivessem eles presentes ou ausentes dos locais atingidos pelas chuvas na ocasião dos desbarrancamentos; por outro lado, a preocupação com a família, os vizinhos e alguns membros da comunidade também pôde ser avaliada como um fator agregador e de suma importância para a forma como os participantes processaram as perdas vividas em decorrência da catástrofe. $\mathrm{O}$ apoio recebido e fornecido mostrou-se como um fator de proteção para os sobreviventes que, após os momentos iniciais ao desastre, buscaram forças nestas lembranças para lidar com a dura realidade que ainda iriam enfrentar nos dias que se seguiram.

O levantamento das primeiras reações após um desastre é fundamental pois, como nos apontaram Kristensen e Franco (2011), sobreviventes enlutados são comumente expostos a eventos potencialmente traumáticos tais como ameaças a própria segurança ou mesmo serem testemunhas de eventos terríveis, os quais podem afetar sua saúde mental - realidade familiar a vivida por nosso grupo de entrevistados. A combinação de trauma e perda pode levar a reações tanto de estresse como de luto complicado, e nossos entrevistados foram indubitavelmente atingidos em diferentes esferas de suas vidas, aumentando o risco para que este quadro se desenvolva, agravados ainda pela falta de atendimento especializado, bem como de apoio dos profissionais envolvidos na reconstrução das cidades (como discutiremos mais adiante). 


\title{
5.2. DESAPARECIMENTO DE MEMBRO DA FAMÍLIA
}

\begin{abstract}
$O$ ano de 2011 foi emblemático no número de desaparecidos nos desastres ocorridos no Brasil, tratando-se de centenas de pessoas. No entanto, sequer se trata de números: há uma elaboração individual, familiar e coletiva do luto que não se deixa fluir, fica contida e mal resolvida, porto de angústias pelo misto de mortes comprováveis e outras tantas presumiveis a lembrar que a fragilidade da vida não é apenas dos que se foram, mas dos que sobreviveram e permanecem assombrados.
\end{abstract}

(VALENCIO, 2011)

O desaparecimento de um ente querido é sempre uma vivência traumática em qualquer contexto e envolve sentimentos muito ambíguos, tais como desespero frente ao desconhecido, culpa, impotência, medo, angústia, raiva, tristeza ao mesmo tempo em que se mantém acesa a esperança no reencontro e a fé em boas notícias - ambivalência esta comumente agravada pela não confirmação nem da vida nem da morte dos ausentes (BOSS, 1999).

Em casos de desastres como o ocorrido na Região Serrana do Rio de Janeiro em janeiro de 2011, é comum que pessoas não sejam localizadas, atribuindo-se a estas o status, ainda que temporário, de desaparecidas. Em nosso estudo, esta estatística se manteve e grande parte da população atingida pelos deslizamentos e desbarrancamentos era moradora das encostas e comunidades carentes das cidades de Petrópolis, Teresópolis e Nova Friburgo, sendo, consequentemente, o local que concentrou o maior número de pessoas sem localização definida.

Diante desta realidade, além das múltiplas perdas vividas pelos moradores da região, dedicamo-nos a estudar, em especial, os casos nos quais havia também a história da perda de um familiar que nunca foi localizado. O desaparecimento de pessoas pode ser considerado, entre as perdas decorrentes do desastre, as que mais geram sentimentos conflitantes, e sendo assim, todos os participantes desta pesquisa viveram perdas materiais, pessoais e/ou sociais importantes ao mesmo tempo em que tiveram um ou mais membro(s) da família desaparecido(s) após as chuvas que assolaram as cidades da região, o que, em tese, compromete ainda mais um quadro já bastante difícil de ser elaborado. 
Nos casos apresentados, podemos perceber que, apesar das fortes evidências de que os familiares desaparecidos tivessem falecido nos desabamentos ou demais ocorrências causadas pelas chuvas, a incerteza de seu paradeiro e dos eventos que antecederam seu desaparecimento levou os participantes a apresentarem sentimentos muito ambivalentes - e alguns, ainda no momento da pesquisa, demonstraram ter alguma esperança de reencontrar vivos seus entes queridos:

Quando me disseram que a Dani tava desaparecida eu tinha acabado de sair do hospital, tinha passado muito mal quando vi que a casa tinha caído toda, e aí voltou tudo de novo (choro). Ninguém sabia dela, onde ela tava na hora, com quem ela tava... por que não podia ter se machucado e ido parar no hospital? Por que não podia ter ficado isolada naqueles lados que caiu tudo? Podia, né? Mas ninguém acreditava nisso, só eu... fica até parecendo que você é completamente maluca, mas se eu não achei ela, então de vez em quando a gente se pergunta onde ela tá (choro). Eu sei que parece impossível, mas a cabeça e o coração da gente nem sempre sabem a mesma coisa, e aí cada dia eu penso uma coisa dela e do que aconteceu... (Luzia, 32 anos).

Eu vi o Pedrinho indo ajudar a moça da casa lá de perto, e vi ele ajudar a tirar o gato da vizinha de cima do telhado que tava todo assustado, você logo vê que era um menino de ouro, que não tinha tempo ruim, queria ajudar todo mundo...e ele é forte, sabe? Quando não vi mais ele, achei que ele tinha ido ajudar em outro lugar, outras pessoas, ele sempre correndo pra lá e pra cá naquelas ribanceiras, conhecia ali tudinho! Mas chovias tanto aquele dia, tava tudo caindo... aí o tempo foi passando e ninguém mais sabia nada dele... eu cheguei a sonhar que ele tinha ido ser bombeiro só pra ajudar as pessoas... quem dera a gente descobrisse que foi isso...mesmo com todo mundo dizendo que todo mundo que sumiu lá aqueles dias morreu, eu não vi mais, aí fica sempre aquela pontinha de esperança dele aparecer um dia lá, com aquele sorrisão bonito na cara... (Nadir, 50 anos)

Eu costumava falar com meu pai pelo telefone quase todo dia, eu gostava de saber se ele tava bem, se tava tomando os remédios e se alimentando direito porque, depois de um tempo que você sai de casa, você vai se acostumando com a ideia de que os pais vão ficando mais velhas e podem morrer, mas não é porque ele já estava mais velho que ele não poderia ter escapado dessa chuva, não é? Ele sempre foi um touro, forte, agitado, alegre, poderia muito bem ter saído e procurado um lugar mais seguro pra se proteger... mas se eu perdi até minha Igreja, minha loja, tudo foi parar no chão, imagina se ele ia ter sumido sem falar comigo só pra depois aparecer do nada...eu não quero me enganar, não acredito em coisas de outro mundo, mas quando você não encontra, é muito difícil aceitar... depois de um tempo você não sabe mais... quer acreditar, mas não sabe mais. (Ariane, 37 anos) 
A falta de certezas e, especialmente, a ausência de corpo, dificulta o processo de concretização da perda e algumas pessoas podem até mesmo não elaborar o luto por falta de comprovação da morte do ente querido (BOSS, 1999). No caso dos desaparecidos das chuvas na Região Serrana, muitas evidências apontavam para o fato dos desaparecidos terem perecido nos locais de desabamento ou até mesmo terem sido levados pela correnteza das chuvas, o que teria inviabilizado a recuperação e identificação de seus corpos, e essa impossibilidade de materializar a perda pode ser entendida como um fator de risco no processo de elaboração da perda de nossos participantes.

O desaparecimento de pessoas, por si só, já gera uma série de dúvidas acerca do que realmente aconteceu ao fisicamente ausente, e se este desaparecimento perdura a ponto de não ter um fechamento, estes questionamentos também se eternizam, gerando mais sentimentos de ambiguidade, culpa e frustração, corroborando com os achados de Valencio (2010). Em nossos relatos, podemos perceber que a não localização dos corpos gerou nos enlutados muita dor e ambivalência:

Nossa, eu pensei muitas vezes, toda vez que tinha reportagem falando do pessoal que tinha ficado ilhado nos lugares que caiu tudo, que não tinha telefone nem computador, eu achava que uma hora ela ia aparecer, que ia ter algum sinal de vida, qualquer coisa que a gente pudesse ter esperança de que uma hora ela ia voltar... eu sei que era difícil, mas a gente não pode desacreditar nesses milagres...nunca que a gente consegue desistir de alguém que a gente não achou... tanta gente reapareceu depois de um tempo porque tava isolada ou porque tava machucada no hospital... por que não podia ser a nossa? Eu queria muito que fosse... Podia, mas infelizmente não foi... eu penso nisso toda hora, e sei que não é uma coisa que acontece sempre, mas eu queria tanto! (Zenaide, 44 anos)

A gente escuta cada história... avião que cai e gente sobrevive, pessoa que fica soterrada uns dias e depois os bombeiros acham, tem de tudo, por isso a gente sempre acreditou que uma hora a gente pudesse achar ele... eu procurei, eu pedi ajuda, eu corri os quatro cantos dessas delegacias, conversei com todos os bombeiros que trabalharam lá, mas também vendo aquele monte de gente morta, sem casa, machucada, fica difícil acreditar por muito tempo... mas se eu te disser que até hoje eu ainda olho pra porta e espero ele entrar trazendo um baralhinho pra gente jogar? Que eu lembro dos almoços que a gente fazia lá em casa e de como a gente ria e se divertia com as coisas bobas da televisão e não tinha medo de falar de futebol, de política, de tudo! Isso acontece, não sei por que... acho que é saudade... (Osmar, 51 anos) 
Eu queria encontrar nem que fosse um pedacinho, uma partezinha dela, porque assim, sem nada, fica difícil acreditar que ela foi embora pra sempre, sabe? Fica sempre uma pontinha de esperança na cabeça da gente, mesmo sem querer... eu acho as vezes que eu tô ficando maluca em pensar isso, mas não é muito maluco ninguém achar uma pessoa inteira, nadinha, nadinha? Como pode sumir assim, sem nem deixar pista? Isso é muita loucura, não ter uma confirmação real dela ter morrido, que nem se não tivesse sobrado nem uma parte dela pra contar a história do que aconteceu... Muito ruim mesmo pra entender e de deixar pra lá, porque nem pra saber o que aconteceu com ela eu tenho resposta, e sem nadinha dela a gente nunca vai saber... (Zenaide, 44 anos)

A não localização dos corpos dos familiares ausentes os manteve estatisticamente, por um período de tempo, como desaparecidos em decorrência das chuvas, e apesar da chance de sobrevivência à catástrofe ser mínima, foram realizadas buscas pela Defesa Civil por cerca de 2 meses ininterruptamente. Ao final deste período, os grupos de resgate foram desmobilizados e cerca de 350 pessoas cadastradas como desaparecidas nas cidades atingidas pela chuva na região não tiveram seus corpos identificados pelos órgãos responsáveis. Este dado corrobora o exposto por Kristensen e Franco (2011) que afirmam que, nos casos de desastre, muitas pessoas são vitimadas e seus corpos nunca são resgatados.

As Prefeituras, com vistas a ajudar às famílias a resolver questões burocráticas, emitiu após cerca de 6 meses da data do início da tragédia um certificado de morte presumida, com o objetivo de permitir que os beneficiários diretos tivessem seus direitos legais assegurados. Além do documento legal, foram realizados enterros coletivos simbólicos, nos quais todos os desaparecidos da região foram declarados como mortos e tiveram, em caixões lacrados contendo fotos escolhidas pelas famílias, seus velórios e enterros providenciados pelas Prefeituras da região.

No entanto, apesar da chamada presunção de morte, a angústia dos familiares que aguardavam informações sobre a localização do ente desaparecido não cessou, mesmo sabendo que este, possivelmente, fora soterrado ou levado pelas enxurradas:

O que mais me doía era saber que eu não ia mais ver meus irmãos, e, pra piorar, tive que enterrar um caixão vazio pra cada um (choro). Imagina se um dia eu pensei na minha vida que eu ia ter que escolher caixão pros meus irmãos pra saber que não tinha nada lá dentro? Eu chorei por tudo isso... você já sofre 
quando perde, mas se perde assim, do dia pra noite, e nem se despedir direito você pode? Eu não queria nem olhar na cara do funcionário da funerária porque parecia que eu tava sacaneando ele com essa história de querer escolher um caixão pra não colocar nada... dois irmãos, uma vida toda juntos e eu pegando um pedaço de madeira e uma foto e pronto, enterrei...errado isso, sem sentido... (Verônica, 28 anos)

Desde criança você aprende que as pessoas morrem, mas ninguém te ensina que elas podem morrer e você não ter direito a enterrar o corpo... eu tinha medo de defunto quando eu era pequeno, mas depois a gente cresce e entende que é importante o velório, e onde já se viu não sobrar nada pra gente velar? O que a gente visita no cemitério, uma caixa vazia? Foi horrível todo mundo sendo enterrado junto, como se todo mundo tivesse sido encontrado, quando na verdade não tinha nada nem ninguém ali... Então era melhor não fazer nada, só rezar uma missa e pronto, acabou! Parece que é só pra gastar um dinheiro ali e dizer que fez pra agradar os outros, mas quem é da família mesmo tá achando aquilo uma coisa de outro mundo...ontem era vivo, hoje ninguém sabe, amanhã vou dizer pras crianças da família que ali naquele túmulo tem alguém? Não tem e isso é o que me incomoda demais! (Bruno, 25 anos)

Eu imagino que a ideia não era ruim, mas quando que a gente vai saber o que aconteceu com minha sogra só de ler no papel que ela morreu? Faz sentido ter um papel dizendo que uma senhora de 72 anos morreu se a gente não sabe nem como, nem onde nem que horas nada disso aconteceu? Aí colocam que ela morreu de causa desconhecida? Como é isso? Não pode, isso é errado, a pessoa vive uma vida inteira, cria filho, ajuda a cuidar dos netos e vira só um papel? Muita falta de consideração pelas pessoas! Meu marido ficou chocado com essa coisa de entregarem um papelzinho e nem pra colocar que a mãe tinha morrido na enchente, como se ela pudesse ter só caído morta no meio da rua e pronto: causa desconhecida! O filho quer enterrar a mãe com a verdade, aquilo que aconteceu com ela, assim ele respeita a vida que ela teve e que fez parte da nossa esses anos todos... nem saber isso a gente pôde... (Olímpia, 43 anos)

Fica evidente que nem o documento emitido pelos órgãos responsáveis nem $\mathrm{o}$ ato ecumênico em homenagem as vítimas respondeu aos questionamentos dos familiares sobre o que de fato aconteceu a seus entes queridos. Para alguns enlutados, é justamente a partir da identificação do corpo e da realização dos rituais fúnebres que o processo de luto se inicia, e sem uma destas etapas, este percurso pode estar comprometido, corroborando assim com os achados de Oliveira (2008), quando esta nos aponta que a incerteza do paradeiro do familiar desaparecido e a falta de rituais são fatores complicadores para a elaboração dessa vivência tão ambígua. 
Perder um ente querido é sempre um fato marcante e doloroso em nosso ciclo vital, e o processo de elaboração dessa perda demanda tempo e energia; um aspecto importante no início de toda jornada de luto é justamente a realização de rituais que, historicamente, manifesta diferentes formas de despedir-se, costume este presente de forma peculiar em todas as culturas (KOURY, 2003). Nos casos dos desaparecidos de nosso estudo, a impossibilidade de realizar os rituais com o corpo do familiar ausente foi concreta e altamente frustrante para os enlutados.

Vale ressaltar que os desastres possuem outra particularidade que se apresenta também como um fator de risco a saúde dos enlutados: mesmo quando o corpo é localizado, o ritual pode não ser realizado da forma como a família deseja. Para alguns de nossos participantes, por exemplo, foi vetada a autorização para reconhecimento dos corpos e os caixões foram completamente lacrados devido ao avançado estado de decomposição dos cadáveres, e esta impossibilidade de concretizarem a perda dos que foram localizados também pode dificultar o processo de elaboração do luto.

Em seus relatos, os entrevistados queixaram-se da postura dos funcionários do Instituto Médico Legal e dos Hospitais Regionais que não autorizaram as famílias a reconhecerem seus familiares, alegando que somente os profissionais legistas tinham condição de atestar a identidade dos localizados. Para alguns enlutados, a verificação dos restos mortais encontrados, mesmo em processo avançado de decomposição, era fundamental para a materialização da perda, e estes se sentiram lesados no direito de estar com seus entes queridos neste último momento:

A moça do IML me disse que tinham achado minhas irmãs, mas na hora de me deixar entrar lá não quiseram... mas eu devia poder, eram minhas irmãs! E se eles tivessem identificado errado? A família é que sabe se é ou não a pessoa! Tanta gente morreu naqueles dias, tanta menina, menino, gente de tudo que era tamanho, cor, idade, e eu só queria saber se eram elas mesmo! Já estava difícil não achar meu pai, aí quando acharam elas eu não posso ver? É como se não tivesse achado, quem me garantia que eram elas era um médico que tava trabalhando 20 horas sem parar desde que começaram a cair os barrancos... claro que podia estar errado! Todo mundo tão cansado naqueles dias, vendo aquele monte de documento, de um jeito ou de outro ele podia errar e eu tava me oferecendo pra identificar, eles deviam levar isso em consideração... (Bárbara, 25 anos) 
Pessoal do hospital veio dizer que o corpo da minha cunhada e dos meus sobrinhos estava lá no salão da igreja que eles tavam usando de lugar de apoio, mas o médico não deixava ninguém entrar porque disse que, no olho, ninguém ia saber se era ou não era... mas a gente quer ver, né? Quer saber se não pode estar errado alguma coisa! E depois quando veio, veio tudo lacrado... será que tinha alguma coisa lá dentro? A gente ouve tanta história! Imagina os meninos, criancinha, tem que ser enterrados direito, pra descansar em paz... eu fico até pensando no que meu irmão ia falar se ele soubesse que enterra os filhos sem eu ter visto... e como a gente tem certeza de que não tinham achado só um e disseram que acharam o outro só pra gente parar de ir lá reclamar? (Gerson, 49 anos)

Quando eu soube que tinham achado minha sobrinha num córrego, fui correndo pro IML pra ter certeza, e aí me disseram que ela já tinha sido identificada pelo prontuário que ela tinha no posto de saúde, mas e daí? Uma menina de 12 anos, uma princesa, achada num valão, e me proibiram de ver, de arrumar ela (choro). Isso não tá certo, a gente tem direito de estar ali, com eles, uma última vez...naquela hora que todo mundo já perdeu tanta coisa, será que custa muito pro médico deixar a gente entrar lá e dar uma ajeitada neles? Nem aberto o caixão estava, nem isso! Disseram que era por causa do cheiro, do tempo, mas e daí? A gente é família, deixa cheirar, vai ser só ali até a gente se despedir, depois acabou, mas deixasse aberto pra gente ver ela, eu queria muito... (Flávia, 33 anos)

Como podemos notar pelo relato de nossos participantes, os rituais não se restringem apenas aos cultos e ritos de despojo do corpo propriamente dito, mas servem para o reconhecimento individual e social da morte através da validação e do respeito de quem vai ao local onde o corpo está e seu papel na vida do falecido - como aquele(a) que tem capacidade afetiva para reconhecer o ente morto. Além disso, podemos notar uma forte preocupação dos enlutados com a forma como este corpo seria sendo manipulado e cuidado pelos profissionais após terem sido tão lesados pelas chuvas que os levaram.

Raiva é uma das possíveis reações frente à ausência de informações claras e concretas assim como às restrições impostas pelos profissionais envolvidos nas buscas e/ou reconhecimento das vítimas. Este sentimento é comumente direcionado contra as autoridades, equipes de resgate, legistas e funcionários das empresas funerárias principalmente porque muitos familiares consideram lenta a resposta dos profissionais ou por crerem que estes não sabem lidar de forma adequada com os enlutados e seus anseios, como já vimos nos relatos acima.

A não realização dos rituais - sejam eles culturais, religiosos ou específicos de cada grupo familiar ou mesmo a realização de formas alternativas dos mesmos (como no caso do enterro coletivo realizado na Região Serrana) - pode gerar 
sentimentos como culpa, impotência, tristeza, consternação, indignação e até mesmo ansiedade (BOSS, 1999). Alguns entrevistados, por exemplo, afirmam que apesar da certeza da morte ter sido imediata, a ausência do corpo e a imposição da realização dos rituais simbólicos gerou sentimentos de angústia e tristeza em toda a família e nos amigos mais próximos:

Eu sabia que ela estava morta, mas você sempre espera poder enterrar as pessoas, acho isso normal! Eu não entendo como as pessoas podem enterrar um caixão com uma foto e nada mais dentro... pra onde a gente vai se ninguém pode rezar pela gente?Eu fico indignado com uma coisa dessas! Minha esposa diz que isso é bobagem minha, que eu posso rezar onde eu quiser, mas eu sei que lá onde ela está não tem nada dela, então nem vou no cemitério. Eles tiraram até isso da gente, o direito de enterrar nossos parentes do nosso jeito... uma pressa em parar de procurar as pessoas, de seguir em frente e a gente não podia nem decidir se era aquilo mesmo que a gente queria, que a gente pretendia pra alguém que a gente amava tanto...os amigos da Igreja tudo querendo prestar suas homenagens e a gente naquele lugar cheio de caixão e tudo mais sem nem ter certeza do que tava ali dentro... não tem como aceitar uma coisa dessas sem ficar indignado, tem? Impossivel! (Bruno, 25 anos)

A gente sabe que elas morreram, mas cadê? Ninguém sabe dizer nada, a gente recebe uma certidão de óbito, mas no caixão não tem nada, no cemitério não tem nada além de um túmulo vazio, e em casa a gente não sabe dizer se elas morreram rápido, devagar, se sofreram ou não, não sabe nada, e isso é que mata a gente! O médico do IML disse que muita gente deve ter morrido dormindo, mas quem sabe quem tava dormindo e quem tava acordado? Ele pode saber de gente morta, mas não pode dizer que a pessoa tava dormindo ou acordada, se sofreu muito ou pouco, até porque ele não sabia se a pessoa tinha medo de chuva, se tava assustada, isso não tem como eles saberem... Tem gente que pode ter batido a cabeça, desmaiado e morrido soterrada, mas tem gente que pode ter ficado um tempão embaixo da terra tentando respirar e morreu sufocado... olha que horror! (Hortência, 37 anos)

Não entendo como a gente pode enterrar as pessoas todas juntas sabendo que não tem ninguém ali... minha mãe me educou na Igreja, meu padrasto merecia ser enterrado do lado dela, e aí me falam que eu tinha que enterrar um caixão vazio junto com mais umas 100 outras pessoas que também não estavam ali, e me dar por satisfeito porque a Prefeitura ia pagar tudo? Eu sei o que minha mãe queria, o que ela merecia ganhar e não era assim, desse jeito... tanta coisa que o pessoal da Igreja queria fazer, os cantos que a gente queria entoar e lá, com todo mundo junto, cada um com uma religião, a gente não pode fazer do nosso jeito pra não desrespeitar o espaço de ninguém, cada um tem sua crença nessas coisas...eu acho que muita gente ali ficou como eu, se sentindo desrespeitado na sua crença e no espaço que a gente teve pra se despedir... Não posso aceitar uma coisa dessa! (Fernando, 26 anos) 
Para lidar com tantas ambivalências, é muito comum que os enlutados por desaparecimento elaborem histórias que justifiquem os acontecimentos ou mesmo criem histórias que deem sentido a algo completamente incompreensível como a ausência de um ente querido de forma abrupta e violenta, e percebemos que nossos participantes buscaram, em seus registros, formas particulares de interpretar os eventos decorrentes do desastre. No entanto, estas construções simbólicas podem interferir diretamente no processo de enfrentamento do luto, já que a incerteza pode sustentar a negação da perda e fantasias acerca do desaparecido não estar morto podem prolongar, retardar ou mesmo impedir o enlutamento, como podemos notar na fala destes entrevistados:

Eu sei que muita gente desaparece por aí sem dar notícia, que aproveita uma chance e sai fugido por aí, nem se importa com a família nessas horas, e você até pensa nisso pra tentar achar que um dia vai ver de novo, mas quando acharam minha cunhada e meus dois sobrinhos eu sabia que ele não tinha ido pra lugar nenhum, que eles estavam em casa mesmo, e todo mundo acabou morrendo ali mesmo... mas não é normal acharem os três e ele não? Eu fico pensando... quem sabe se ele não saiu pra ajudar e acabou em outro lugar? Quem sabe se na hora de sair pra ajudar se machucou e ficou um tempo em outro lugar... mesmo triste, eu cheguei a pensar que ele podia ter até entrado em coma e ter ficado entrevado em algum lugar... Mas podia ter saído e corrido pra buscar ajuda pra família e aí é que a gente cria esperança... (Gerson, 49 anos)

Minha amiga do trabalho disse que a gente não podia perder a fé porque tem gente que fica desaparecida um tempão e depois reaparece, mas todos os casos que a gente conhece não são desses de chuva, né? Eu ficava ouvindo ela dizer e tinha dia que eu concordava e tinha dia que eu achava que ela devia ficar quieta porque ela não sabia de nada... raiva dela porque a gente não pode ficar acreditando nessas coisas, porque daí não acha e só chora mais...aí tem sempre aquele dia que você tá com tanta saudade que quer mais é acreditar que a pessoa vai voltar, ainda mais eu que era colada no meu irmão... na verdade eu nunca senti de verdade que ele tinha morrido, aí vira e mexe ainda brilha um pouquinho essas ideias dele aparecer de novo... (Mônica, 42 anos)

O mais inacreditável é que tem gente que as vezes fica 10, 20, 30 anos desaparecido e depois aparece de novo, quem vai dizer que não pode? Eu sei que não deve ser o meu caso, mas a Deus tudo é possível, e não sou eu quem vai dizer, já que ninguém nunca achou nada, eu me seguro num dia após o outro, pra quem sabe ser surpreendida um dia com ele voltando... tem como a gente ter certeza de tudo nessa vida? Então pronto, eu fico assim, de uma hora acreditar e na outra saber que não tem volta...porque acho que acreditar não é tão ruim assim, faz a gente querer manter as coisas prontas pro caso da pessoa voltar e ver que você nunca esqueceu... (Tereza, 42 anos) 
Frente a qualquer tipo de perda, a pessoa se depara com a difícil dor da separação. O enfrentamento deste luto está diretamente relacionado ao padrão de relacionamento estabelecido com o falecido em vida, seu papel na dinâmica familiar e/ou social, o modo como a pessoa morreu, as crenças sobre a morte e o suporte social, como já referimos nos estudos de Parkes (2009). No caso de morte súbita - como ocorre nos desastres - não existe tempo para o reconhecimento da gravidade e da possibilidade do óbito; o sujeito depara-se com uma perda brusca de um ente querido. Enfrenta-se, como já referido anteriormente, a dificuldade, no caso das catástrofes, em lidar com o tempo de localização e o estado de conservação dos corpos, retardando ou mesmo impossibilitando a materialização da morte e, consequentemente, a realização dos rituais fúnebres da forma como a família e os amigos enlutados idealizam.

Podemos concluir, em nosso estudo, que além das perdas humanas confirmadas, o desaparecimento de um ente querido mostrou-se como um agravante no enfrentamento das perdas. A falta de rituais dificultou a concretização desta despedida para nossos participantes, não permitindo que agradecimentos e questões consideradas pertinentes pudessem ser manifestados, impossibilitando, também, a resolução de algumas pendências no relacionamento com o falecido, prejudicando o enfrentamento e elaboração desta perda. Mortes abruptas e inesperadas trazem muitas vezes este desconforto e sentimentos como remorso e culpa podem se abater sobre o enlutado.

Os rituais, marcos culturais e religiosos, confirmam e validam a perda, permitindo que a pessoa se enlute. A morte estabelece o fechamento do desenvolvimento de nosso ciclo vital, não podendo ser descuidada ou negada aos que aqui permanecem (KOURY, 2003). Para nossos entrevistados, a materialização da morte ficou comprometida e, sem os ritos, a perda não pôde ser validada e reconhecida coletivamente da forma desejada, fato este que pode levar a um retardamento ou inibição do processo de luto, além de comprometer a forma como os enlutados elaborarão suas perdas futuras. A impossibilidade de realizar os rituais fúnebres planejados pelas famílias enlutadas, como ocorreu em nosso estudo, pode dificultar o processo de luto como um todo, mesmo que outras esferas da vida dos sujeitos sejam reconstruídas. 


\subsection{PERDAS MÚLTIPLAS}

Porque entre o sim e o não é só um sopro, entre o bom e o mau apenas um pensamento, entre a vida e a morte só um leve sacudir de panos...

(LYA LUFT, 2003)

Quando falamos sobre perdas múltiplas nos contextos de desastre, tendemos a nos voltar às perdas concretas, tais como as perdas humanas por morte, a perda da casa, do emprego, dos locais de referência como igrejas e escolas, além dos bens materiais como móveis, eletrodomésticos e outros, mas também devemos nos atentar às perdas simbólicas, tais como a perda de um ou mais papeis familiares diante da morte de um de seus membros; a perda do status de vizinho (a), de trabalhador(a), de membro de uma congregação; perda de referenciais na comunidade; do sentimento de pertencimento; da privacidade nos casos de quem precisou ser removido para um abrigo ou moradia de parentes; do conforto; dos sentimentos de segurança e confiança relacionado a ter um lar; e, em maior instância, do próprio self, completamente transformado diante de tamanha adversidade.

Nesta categoria, analisaremos algumas destas perdas concretas e simbólicas (muitas vezes compreendidas como secundárias), buscando ampliar nossa reflexão acerca dos impactos do desastre na vida dos sujeitos, ou seja, na forma como nossos participantes lidaram com tantos lutos concomitantes e como se reorganizaram quando tanto haveria que ser reconstruído.

\section{- Perda da casa}

A casa faz declarações tanto públicas quanto pessoais (...) ao criar uma casa, as pessoas tanto descobrem e criam sua posição social quanto moldam seu mundo interior.

(CALDEIRA, 2000) 
A casa nos remete não só a proteção física, mas também as noções de conforto, harmonia e segurança. Casa e lar são aspectos complementares no imaginário dos seres humanos, na qual casa está relacionada à estrutura física e material do local onde residimos, enquanto lar está diretamente ligado à sensação de pertencimento, convivência e apego (MARCHEZINI, 2011). No caso de nossos participantes que perderam suas casas - seja por perda total ou interdição da mesma - a perda se refere não só à residência, mas também ao local que eles escolheram para viver em família e construir suas histórias. Desta forma, o luto não diz respeito apenas ao espaço concreto com suas paredes, mobílias e eletrodomésticos, mas também ao resultado de anos de trabalho, dedicação e memória que esta família viveu junta, o que inclui não só bens materiais, mas também lembranças e passagens que parecem só fazer sentido naquele lugar.

Podemos perceber no relato dos participantes que a perda da casa foi significativa especialmente em três diferentes aspectos: a) a perda da moradia/segurança/local para criar os filhos; b) a perda de bens de valor afetivo como fotos, documentos, presentes, brinquedos e demais objetos inestimáveis; e c) a perda de bens materiais, fruto do esforço e trabalho de anos.

Inicialmente, para os participantes, a perda da casa onde moravam significou a perda de um local seguro e estável onde escolheram construir suas histórias em família e acompanhar o crescimento dos filhos. Para os entrevistados, ter que abandonar a casa foi algo doloroso e que significou abrir mão da privacidade e de uma rotina até então conhecida.

Eu ficava pensando em todo o tempo que a gente tinha morado ali, de quanta coisa a gente viveu naquela casa, nas fotos na parede, no dia a dia mesmo, que a gente tomava café na mesa da cozinha, essas coisas que a gente só dá mais valor quando perde mesmo (...) nem sei dizer quantas vezes eu reclamei das paredes que tavam manchadas, da torneira pingando, de quantas vezes eu tive que subir no telhado pra ajeitar a antena da televisão só pra mulher poder assistir as novelas dela... mas lá era minha casa, onde meus filhos nasceram e estavam crescendo, viviam brincando pelos corredores, tinham tudo ali dentro pra ser crianças felizes e saudáveis... e a gente agora nessa situação de não ter onde morar (choro). Muito difícil viver assim, sem ter um teto nosso, como se fosse mendigo... (Sérgio, 49 anos)

A gente sabe que a casa é aquele lugar que a gente vai depois do trabalho e pode esticar a perna no sofá, fazer um churrasquinho com os amigos no final de semana, que as crianças podem brincar enquanto a gente termina de fazer a 
comida... aí perde tudo isso e tem que cuidar dos filhos na casa dos outros, e não tem a mesma liberdade, fica tudo muito diferente, bem pior, não sabe como sentar na mesa, se ajuda ou se atrapalha ali...eu luto tanto para criar meus filhos, pra dar pra eles um lugar de amor e que eles podiam chegar e ficar tranquilos pra agora ter um espaço emprestado, sem liberdade, com um monte de roupas amontoadas no canto, só podendo falar baixo e comer quieto pra não incomodar ninguém...a gente sabe que é a situação pra ser por um tempo, mas aí esse tempo vai ficando cada vez mais tempo e não sabe quanto ainda vai ficar nessa situação e isso é muito incômodo... (Mônica, 42 anos)

Quando você casa, quer casa, não é o que diz o ditado? Então você corre atrás de um lugar onde possa ter seus filhos, criar eles, ter sempre pra onde voltar depois de um dia de trabalho, né? Como fica se depois de mais um dia você simplesmente vê esse lugar caindo, de uma hora pra outra? Aí você sai e fica morando em outro lugar, onde tudo que tem ali é de outras pessoas, com gente estranha, que você não sabe se é boa ou ruim, e sabe que não volta mais pra sua casa mesmo porque ela não existe mais... sabe o que é tomar banho, ir no banheiro, acordar todo dia preocupada de ficar assim a vida toda?Tem hora que a gente não sabe nem onde está direito e isso nunca acontece na casa da gente... tem fechadura na porta, tem trinco pra te dar segurança, tem sua roupa e sabe direitinho de onde veio aquilo tudo que tá ali dentro e, sem casa, tudo que é seu já foi de alguém... Horrível, de verdade! (Suely, 39 anos)

Neste aspecto, a casa servia não só de abrigo para a família, mas também como um porto seguro para que cada membro pudesse se expressar e se constituir dentro e fora de seu círculo familiar, e por isso perder a moradia é também perder parte deste processo. Neste momento em que muitas perdas ocorreram concomitantemente, sentir-se seguro é um fator de proteção no enfrentamento dos lutos, mas se além da dor e do sofrimento adicionamos medo, falta de privacidade e desesperança, este processo pode estar ainda mais ameaçado.

No instante em que os participantes perderam suas casas, não é só a estrutura física e os bens materiais que são alienados, mas também uma parte da memória da família presente em cada objeto de decoração, fotografias, documentos, roupas, brinquedos e outros itens considerados de valor sentimental e, por essa razão, irreparáveis (objetos de valores muitas vezes ínfimos, mas que carregam em si muitos significados). Pudemos perceber sentimentos de tristeza, indignação, consternação e desorientação diante da perda destes pertences, e a dor deste luto está relacionada também ao carinho e apego às lembranças de cada momento vivido em família. 
Sabe aquela foto que a gente bota perto da cama? Aquele radinho de pilha que tem desde moleque? O carrinho de brinquedo dos meninos, o pijama velho, aquelas coisas que a gente vai guardando toda vida... tudo vai embora, não sobra nada. A gente não recupera essas coisas... tem coisa que tem cheiro, tem mancha de comida ou já tá tão gasto que não tem nem mais cor, mas a gente gosta como se fosse novo...eu era muito apegado nessas coisas, sempre gostei de guardar coisa das crianças, de tirar foto de tudo que a gente fazia e guardava, bem bonitinho, pra de vez em quando ficar lá olhando e lembrando com saudade das coisas que a gente já viveu e dos momentos que já passaram e agora não sobrou nada, nada mesmo...quando a gente não pode ter filho nosso, qualquer lembrança é mais importante ainda porque foi uma luta conseguir os meninos pra gente criar... muita coisa ficou agora só na cabeça da gente... (Cândido, 53 anos)

Ah, dói muito olhar as coisinhas da gente lá, jogadas na lama... nem a bolsa eu lembrei de pegar... tive que tirar tudo de novo, documento, certidão, tudo... nem dinheiro pra comprar um biscoito eu tinha (choro). Eu não consegui acreditar que tudo tinha ido assim, embora, tudo que a gente cuida com tanto carinho, que limpa, que deixa pra usar quando vem visita e agora não sobrou nem das coisas velhas nem das que a gente só pega de vez em quando... aí você percebe que essas coisinhas são as que mais fazem falta, né? Nem certidão de nascimento eu tinha mais, parece até que a gente é indigente... eu queria me apresentar na Delegacia ou fazer alguma outra coisa mas não tinha um documento pra provar que eu era eu... e as coisas que eu tinha do meu enxoval de casamento? Não sobrou nada nem pra contar história... (Nadir, 50 anos)

Eu não sei o que te dizer porque a gente não consegue nem lembrar tudo que a gente perdeu, é tanta coisa... fica uma sensação de que perdeu uma vida toda (choro). Você sempre tem uma coisa ou outra que é sua desde criança, uma roupinha dos filhos que ainda tem cheirinho, uma cadeira que já tava muito acostumada a sentar, aquelas coisas do dia a dia que não dá muita importância... eu lembro de umas fotos que eu tava pra imprimir lá de umas festinhas com as crianças e com uns vizinhos e já tinha separado até um cantinho na casa pra colocar elas, e nessa hora você saber que além das fotos você perdeu todo o cantinho, as coisas que estavam lá pra gente sempre lembrar desses dias felizes... mas aí quando vê que acabou não tem nem mais rumo... perdi o rumo, foi isso! (Tereza, 42 anos)

A perda de fotografias foi o fato mais marcante para todos os entrevistados. É comum que registremos, através das fotos, momentos importantes das etapas de nosso ciclo vital, e com este tipo de registro também construímos parte de nossa história em família e em sociedade. Ao perder as fotografias de si e dos entes queridos, os participantes sentiram-se destituídos de parte de sua própria jornada de vida, como se algo de suas identidades também se perdesse nesse momento. 
A gente sempre tira foto das festinhas de criança, de quando elas têm apresentação na escola, tem até de quando a gente era novinho e vem a chuva e leva tudo... não tem como ter nada daquilo de volta, nunca mais vai ver aquelas fotos, não tem ninguém que tenha, aí você um dia vai esquecendo como era quando era criança, a carinha dos filhos quando eles eram pequenininhos porque a memória da gente não dura pra sempre...eu sei que são só fotos, mas quando você olha pra uma fotografia você não vê só a foto, você lembra da roupa que tava usando, dá risada, do penteado da vizinha, lembra até do que comeu na festinha e de como ficou cansada no dia seguinte limpando a casa... é assim que você conta pros filhos que foi a festa, que você fez pra eles com tanto carinho... triste isso de esquecer as coisas que a gente não vê... (Nadir, 50 anos)

Quando a gente tem filho a gente tira foto de tudo, né? Na minha época não tinha muito disso mas hoje é tão mais fácil que a gente tira foto da criança e das festinhas e dos passeios, de tudo! Vê se agora tem alguma coisa? O que mais me dói é que meu Gustavo sumiu e eu não tenho uma fotinho dele da época de pequeno... na verdade acabou tudo de foto, mas as de agora a gente recupera mais fácil, mas de lá do começo, de quando era gurizinho não sobrou nada... aí fica assim, embaixo da terra, como se fosse só um pedaço de papel, mas a gente sabe que não é...ele sumiu e eu não fiquei com uma foto dele criança e tenho que ficar pedindo pra família me dar o que tiver, porque as vezes os irmãos tem alguma coisa, alguém tem foto com as outras crianças, mas sempre tinha aquela que era a preferida, aquela que fica na geladeira ou naquele álbum mais bonitinho que é só olhar uma foto que a gente lembra de um montão de coisa (choro). (Sérgio, 49 anos).

Tinha tanta coisa na casa do meu pai que nem sei... foto, roupa, bilhetinhos meus de quando eu era garota no colégio, tudo ficava lá, no meu quarto... e eu olho e vejo que perdi ele e meus irmãos, mas também nossas coisas de infância, de como crescemos juntos e isso me aperta ainda mais o coração, fica sem nada pra lembrar... a memória da gente engana, e as fotos ajudam a gente a lembrar melhor, não sei explicar...e eu ainda posso ficar feliz porque as minhas fotos de casamento tem todo mundo junto, mas aí já é todo mundo adulto, e eu não sou adulta desde sempre, tive minha infância e agora não sobrou nada...engraçado como a gente se apega as coisas das épocas da vida, né? (Bárbara, 25 anos)

A perda das fotos e objetos de valor sentimental aumentou ainda mais o sentimento de desamparo e de perda de identidade dos entrevistados e seus familiares. É como se parte de suas histórias tivesse sido abruptamente "apagada", e o sentido de algumas destas experiências ficasse comprometido, já que muitos destes acontecimentos ficaram marcados, particularmente, através desse acervo de imagens e/ou documentais. Outro exemplo claro deste sentimento de perda de identidade está relacionado justamente à perda dos documentos como Registro Geral (RG), Cadastro de Pessoa Física (CPF) e a Certidão de Nascimento (dos próprios entrevistados e dos filhos). 
No dia a gente não conseguiu salvar nada, nem mesmo os documentos da gente... aí você fica pensando em como vai falar pro delegado ou pro bombeiro quem é você, se não tem nada pra dizer que você é você! Acho que a gente só dá importância mesmo pras coisas quando a gente perde porque eu nunca tinha pensado que eu podia me sentir assim, como uma indigente, andando sem nada, sem um jeito de dizer também o que mais eu tinha perdido porque na hora é tanta coisa que você nem lembra... como fala naquela música mesmo: sem lenço, sem documento, nada no bolso e nas mãos... a gente ficou sem nada, nadinha... cada hora que você pensa é uma coisa diferente que você vê que ficou ali, na lama, e ninguém vai achar nada seu pra contar história... eu não tinha como provar que meu nome era o meu, imagina só? Quem pode acreditar que um pedaço de papel faz tudo isso pela gente? (Luzia, 32 anos)

Eu fiquei chocada a hora que eu comecei a pensar nos documentos das crianças que estavam em casa e tudo delas que tava lá... meus filhos tudo sem certidão de nascimento, sabe? Como a gente pensa em coisa grande e depois vai lembrando, vai vendo tudo que perdeu ali pra chuva e, de repente, vem esse estalo: não tem mais aquela folhinha que falava do dia que eles nasceram, que é um dia tão bonito de lembrar, né? E eu ficava pensando que eu precisava ter guardado isso comigo porque as crianças não tem nada pra dizer que elas nasceram de mim e que eи sou mãe delas porque é ali que tem tudo escrito... eи não quero dizer que as coisas que a gente perdeu são tudo pra mim, mas é difícil você ir lembrando dessas coisas e não ficar com o coração apertado porque cada pedacinho da gente é de valor, né? (Tereza, 42 anos)

Nunca vi tanta gente sem rumo que nem aquela noite, e tinha um montão de gente que tava perdida, sem saber o que procurar, só remexendo a lama, chorando e perguntando se alguém podia ajudar... tinha uma mulher do meu lado que só queria achar os documentos dela e do marido, e foi quando ela falou que eu pensei comigo: "Puxa, e agora? Perdi meus documentos!" e ai que eu agachei no chão e comecei a procurar, procurar e procurar... deu aquele estalo de quem não tinha pensado ainda nessas coisas, mas ai bateu aquele desespero porque como que eu ia conseguir fazer as coisas se não tinha nada ali pra dizer que eu era eu mesmo? $E$ tem os documentos de todo mundo ali porque quando a gente saiu de casa, ninguém pensou em pegar bolsa, carteira, essas coisas... a gente vai sobrevivendo daquele jeito, mas quem tem $R G$, CPF, essas coisas é alguém, e quem não tem? Vai fazer como pra conseguir começar de novo? (Sérgio, 49 anos)

Outro aspecto importante em relação à perda da casa diz respeito ao difícil momento de saída da residência sem poder levar consigo seus bens materiais. Para os que tiveram que abandonar imediatamente a casa, a sensação de perder todos os bens que foram conquistados com o suor do trabalho foi marcante no discurso. Além da impotência de não poder recuperá-los, ficou a sensação de que algo da história da família também se perdeu junto com a moradia. 
Quando eu vi o chão se abrindo embaixo dos meus pés, que eu gritei pelo meu Jesus, eu vi que tinha que sair correndo dali, mas nessa hora você ainda olha pro lado e pensa se dá tempo de pegar alguma coisa (...) a gente se apega nas coisas, né? Eu tinha minha geladeira, meu fogão, minhas roupas, tudo que eu trabalhei muito pra comprar... se tivesse alguém comigo lá eu não me preocupava com isso, mas era só eu... peguei logo a foto dos meus filhos (choro). Bateu uma coisa que eu peguei minha carteira também, mas foi assim, no susto...eu que já tava separado da mãe dos meninos a um tempo dava muito valor pras minhas coisinhas, é tudo mais difícil de comprar quando você mora sozinho, e eu não quero parecer ingrato por ter ficado vivo, mas cada coisinha minha ali era meu, de tanto que eu trabalhei na vida! (Emerson, 37 anos).

Eu lembro que eu não queria sair de lá por nada porque a gente luta tanto pra ter a casa da gente, né? Cada pedacinho da casa da gente é da gente que trabalhou tanto, fez tudo que podia pra melhorar os quartinhos, a sala... Mas aí eu pensei nas crianças e elas são tudo que eu tenho e eu sou tudo que elas têm... aí a gente juntou uma trouxinha de roupa e saiu porta afora... mas não é fácil ver as coisinhas da gente ali, largadas... e eu achei que a gente ainda ia pegar as coisas, mas não deu, caiu tudo (choro). Tanta coisa que a gente comprou com sacrifício... as certidões de nascimento das crianças também ficaram na lama... a gente não tinha nada nem pra dizer que a gente era a gente mesmo... uma vida de suor e nem colchão, nem cortina, nem uma roupa de cama ficou intacta, nada mesmo... hoje eu acho que tudo volta, que a gente trabalhando consegue comprar de novo, mas aquelas coisas que eu tinha já era com carinho, é diferente de comprar tudo de novo... (Suely, 39 anos)

Pra mim que sempre criei meus meninos com meu trabalho é mais difícil ainda perder tudo, né? Não que as outras pessoas não estejam tristes e tudo, mas eu comprei tudo aquilo com minhas faxinas, com as horas que eu tive que dormir na patroa pra poder dar escola, comida e as coisas pras crianças... quando eu comprei nossa primeira televisão foi uma alegria... 10 meses pagando pras crianças poderem assistir um desenho e eu, de noite, ver minha novela... tanto sufoco, tanto trabalho e não tem mais nada...eu quero ter coisas simples, mas quero dar o melhor pros meus filhos, e numa hora dessas a gente vê que tudo que a gente trabalha a gente pode perder de uma hora pra outra e não tem como recuperar...eu posso trabalhar mais uns 10 anos e não vou conseguir comprar de novo aquelas coisinhas todas porque a gente vai ficando velha e mais cansada e os filhos vão começar a vida deles e aquilo tudo que a gente tinha ali era importante pra gente... (Tereza, 42 anos)

Como podemos concluir, a casa é um dos mais importantes locais de referência da família, pois nela exercemos diversos papéis e desenvolvemos relações de apego. O lar, reduto da história individual e da família, abarca também essa História de nossa sociedade, pois fala de trabalho e das pequenas conquistas diárias, do compromisso, dos esforços, da vontade de crescer e proporcionar à família melhores condições de vida. 
Cada participante viu-se destituído não só de sua casa, mas dos frutos de anos de labuta, dedicação e comprometimento com seus parentes; a identidade, que também é um processo em construção, vê-se abalada diante dessa perda, e sentimentos de impotência e incertezas quanto ao futuro de si e da família surgem com grande intensidade (MARCHEZINI, 2010).

No entanto, não é só na residência que construímos e desenvolvemos esses papeis, pois vivemos imersos em uma sociedade; em nosso convívio com os outros, as esferas social, religiosa e laboral também são basilares para a construção da identidade. É fundamental que possamos compreender também como nossos entrevistados enfrentaram a perda de seus locais de referência como igreja, trabalho, escola dos filhos assim como a perda dos vizinhos e de seus bairros, devastados pelas chuvas na região.

\title{
- Perda de locais de referência
}

\begin{abstract}
Através de suas ocupações, o homem revela suas motivações, suas preferências, seus interesses, sua maneira de interagir em seu meio, suas habilidades, sua cultura, enfim, revela a si mesmo.
\end{abstract}

(JORGE, 1990)

Diante de uma catástrofe como a ocorrida na Região Serrana em 2011, centenas de pessoas foram atingidas diretamente não só em suas casas, mas também perderam importantes pontos de referência como escolas, igrejas e locais de trabalho. Nestes espaços, interagimos e construímos com outras pessoas novas relações, formamos laços e exercemos nossos papéis de amigo, vizinho, companheiro de trabalho, líder comunitário, entre outros papeis sociais a nós significativos.

Para estes entrevistados, a desorganização e o sentimento de não pertença foram marcantes, dificultando ainda mais o processo de enfrentamento das demais perdas que estavam ocorrendo naquele momento: 
Eu tava tentando chegar na casa do meu pai quando eu olhei assim pra cima e vi que minha igreja tava toda no chão (choro). Poxa, um lugar santo, onde as pessoas se encontram pra orar, pra agradecer, e tudo ali, caído, sujo, perdido mesmo... e quando minha patroa me ligou pra dizer que a clínica tinha acabado também? Os cachorrinhos que estavam lá dentro no hotel morreram tudo (choro). Eu gostava tanto de trabalhar com os bichos que eu senti como se fosse da minha família mesmo... você na hora nem pensa no salário, mas depois começa a pensar e aí bate mais desespero ainda, porque não é só um emprego, é o seu dia a dia todo ali, seus horários, seus colegas, seus chefes, as pessoas com quem você passa mais da metade do seu dia, então de repente ficar sem é um baque não só financeiro mas do que a gente pensa daqui pra frente... (Ariane, 37 anos)

Eu olhei aquilo e não acreditei... isso porque eu sou adulto, imagina meus filhos! Eles ficaram muito tristes, a escola toda sem telhado e sem parede, só uma casca quebrada... os amiguinhos também tudo sem escola, como pode, né? Aí um dia depois a gente soube que a loja da gente também tinha acabado toda, e não tinha mais emprego pra gente... como de uma hora pra outra você fica assim, sem trabalhar e os filhos sem estudar? As escolas que sobraram estavam abrigando os que perderam as casas e metade do pessoal estava sem trabalho porque acabou tudo lá no Centro, uma tristeza só... quem consegue entender uma coisa dessas? Escola pras crianças é muito importante pro futuro, mas eu também tenho que trabalhar pra eles poderem continuar estudando, entende? É tudo um ciclo de coisas que a chuva levou... (Olímpia, 43 anos)

Eu sei que muita gente perdeu muita coisa, eu também perdi meus irmãos, mas a gente fica tão perdido quando de repente fica desempregada... Você se acostuma acordar todo dia, se arruma, sai pra trabalhar e aí, de uma hora pra outra, não tem mais o que fazer... tudo perdido na chuva, cada produto caro, de boa qualidade, não sobrou nada... e eu com dois filhos pra criar, sem emprego? Nossa, a gente se desestrutura, sem dúvida! Fica aquela sensação de que pode faltar dinheiro pras coisas básicas, de tudo que você planeja dar de bom pros filhos e não tem emprego sobrando por aí pra você simplesmente perder um em um dia e arrumar outro no dia seguinte...dá uma insegurança no futuro! (Verônica, 28 anos)

Devemos lembrar que nossos papeis sociais são fundamentais para nossa constituição como sujeitos e a perda de locais de referência leva também, mesmo que temporariamente, à extinção destes, o que pode ser altamente desorganizador para o indivíduo. É a partir de nosso lugar na sociedade que muitas vezes solidificamos nossas identidades e nos posicionamos em relação à comunidade onde estamos inseridos, e por isso esses lutos estão também relacionados à perda de si mesmo no grupo. Vivemos em grupo e com ele trocamos, somamos, somos. É um processo de compartilhamento, onde ensinamos e aprendemos, expressamos e crescemos (JORGE, 1990). 
Em relação à perda do emprego, sentimentos de impotência, medo e desesperança foram identificados, acentuando as incertezas com relação ao futuro de si e da família. Vemos que, apesar de serem empregos muitas vezes considerados temporários, o ato de trabalhar era gratificante e trazia segurança à família, que agora teme não conseguir se reerguer após a tragédia.

A gente trabalha porque precisa, mas também gosta de estar ali, com a mão na massa, fazendo uma coisa que é boa pros outros, que te ajuda também, é bom... aí você vê tudo aquilo perdido, não sobrando nada, e fica se perguntando se vale a pena as horas extras, os dias que deixou de ver a família e os amigos pra trabalhar... só que quando você fica desempregada, aí bate aquele medo, aquela coisa que a gente sabe que só vai conseguir se tiver o salário no final do mês... eu tenho duas filhas pra criar e não é barato, tem muita coisa de escola, de roupa, de tudo! Pra gente que sabe o que é ter que batalhar todo dia pra conseguir comprar as coisinhas pra casa, ficar assim ao Deus dará é muito ruim (choro). Não tem como dizer que eu não fiquei sentida com tudo isso, ainda mais pensando nos bichinhos que morreram ali no Pet Shop e naquela hora a gente só quer ver as pessoas bem, mas depois quando vê que acabou tudo e vai ter que começar tudo de novo, é desesperador mesmo... (Ariane, 37 anos)

Na hora que eu soube que minha loja tinha sido destruída eu sentei e comecei a chorar sem parar, juro! Aí veio gente me perguntar porque eu tava daquele jeito, que era só uma loja de sapatos, que não tinha porque eu ficar daquele jeito se daqui a pouco eu me formo na faculdade e vou trabalhar na minha área, essas coisas... as pessoas não entendem que a gente é boa funcionária em qualquer emprego, porque ali eu tirava meu dinheiro pra pagar minhas contas... como que eu ia pagar meus estudos agora? Eu sei que emprego não é igual a casa e as coisas que muita gente perdeu, mas é dali que a gente tira nosso sustento, que pode comprar as coisas pra dentro de casa, e na minha loja eu sempre aprendia alguma coisa nova, com meu chefe que me ajudava tanto quando eu precisava sair por causa da minha filha que ainda é pequena... eu não tinha só um emprego, eu tinha meus amigos, minha rotina, tudo isso acabou naquele dia... (Flávia, 33 anos)

No dia mesmo eu nem sabia de nada, mas quando minha colega me ligou dizendo que a loja do Seu Pércio tinha ido por água abaixo, eu tremi... poxa, a gente se apega aos colegas, tem o dinheirinho no final do mês, conhece tanta cliente de outros estados que vem visitar a cidade, é um refúgio pra gente também, né? Eu tenho dois filhos adolescentes que querem ter de tudo, e que estão naquela fase difícil, então quando eu ia trabalhar, eu ficava no meu mundo, falando de roupa, de moda, da novela, aquelas coisas que a gente gosta... e eu sou uma boa vendedora, então é difícil aceitar essas coisas porque eu sei que nem sempre a gente trabalha no que gosta, que perde o emprego ou se demite quando não gosta do chefe mas eu gostava e era querida por todo mundo lá, era um lugar muito bom de trabalhar e mesmo quando a gente arruma um outro emprego, dá aquela saudade do pessoal, das risadas... até das confusões eu sinto falta (risos) (Zenaide, 44 anos) 
Como podemos ver, trabalho e emprego são aspectos distintos para nossos entrevistados. Enquanto percebem a importância de ter um emprego para sustentar a família, as despesas da casa e do casamento e para desfrutar na realização de outros objetivos (pessoais ou familiares), a dimensão do trabalho é constituinte, agregadora e fundamental para manter o equilíbrio do dia a dia. Trabalhar está diretamente relacionado à satisfação pessoal, sentimento de pertencer a um grupo, reconhecimento por ser bom profissional na área de atuação, além de permitir trocas com pessoas de fora do núcleo familiar e formação de novas relações afetivas. Perder o local de trabalho e, consequentemente, o emprego, não é só perder o vínculo empregatício e a remuneração, mas também perder referências, lugares e pessoas que ajudavam na constituição desses sujeitos.

Há também aqueles que perderam igrejas e locais relacionados às crenças religiosas que, assim como em relação ao trabalho, podemos destacar não só a perda da estrutura física das congregações, mas um abalo na própria fé, como se a chuva pudesse ter rompido com a noção de segurança que o espaço sacro transmite para seus fiéis:

Você não imagina que uma igreja, um lugar tão grande e de fé, possa virar só um monte de tijolos e lama... ainda mais quando na hora que ela caiu, as pessoas estavam lá dentro, orando (choro). Eu perguntei muito ao meu Deus o porquê daquela tragédia, se a oração tem tanto poder, como tanta gente inocente pôde morrer ali, em solo sagrado?Como que as pessoas podem ter ficado ali, naquele momento de união, e não ser protegidas por Ele? Tem tanta coisa que passa na cabeça da gente que fica até difícil organizar as ideias numa hora dessas $e$ se perde em tanto sentimento... A gente pensa na Igreja como um lugar imaculado, santo, e que está fora desse círculo de maldades e desgraças, mas é uma ilusão porque o mal está em todo canto do mundo... e Ele há de saber, Ele é justo, Ele tem que saber... (Fernando, 26 anos).

Eu e o Edu éramos muito ativos na Igreja, sabe, e não dá pra acreditar que ela se foi... era o lugar onde a gente aprendia a ser melhor, ajudava a educar nossos filhos, cheia de gente de fé e de boa intenção, e não dá pra acreditar que caiu toda... toda aquela água, sujeira, gente morta... tudo profanando um espaço que era de muita oração mesmo... deve ser uma punição, alguma coisa que estava errada pra cair tudo, não sobrar nada... a gente ouve muita história de igreja envolvida com maracutaia, desvio de dinheiro, sei lá, e de repente cai tudo e você fica se perguntando se lá não tinha alguma coisa desse tipo porque pra não sobrar nada, vai que alguém de lá de dentro era envolvido com crime e essas coisas... é pra gente pensar, sabe? (Ariane, 37 anos) 
Para nossos entrevistados, a perda do lugar sagrado refere-se à perda da estrutura, mas também de um lugar santo, de algo que transcende a materialidade. Sabemos que a religião pode ser um grande facilitador no enfrentamento das perdas, assim como pode se apresentar como um fator de risco neste processo de elaboração; em ambos os casos, ela se faz presente e, na ausência de um local destinado às expressões religiosas, os sujeitos podem sentir-se destituídos de um espaço real de ventilação e validação de seus sentimentos.

Em situações de luto, as pessoas tendem a se questionar sobre as razões para tanto sofrimento e dor, e é possível que estes questionamentos se voltem para Deus e até mesmo para a própria instituição religiosa. Isto ocorre muitas vezes porque tentamos retomar o controle de nossas vidas através de explicações racionais diante do alto grau de desorganização após um evento traumático. Assim como as apostas da família referidas por Boss (1999), todos buscamos, em algum momento após uma perda significativa, hipóteses e respostas com vistas a amenizar a angústia e a impotência decorrentes de nossos lutos irreparáveis.

Independentemente de suas crenças religiosas, cada indivíduo reage de forma diferente às situações de perdas (PARKES, 2009). Para compreendermos esta questão de forma mais aprofundada, discutiremos, na próxima categoria, os fatores de risco - e, em alguns casos, a possibilidade destes se apresentarem como fatores de proteção - tais como o papel da fé na reorganização do sujeito, pode surgir também como um fator de risco durante esta difícil trajetória de elaboração do luto para nossos entrevistados.

\subsection{FATORES DE RISCO}

Não digam que isso passa, não digam que a vida continua, que o tempo ajuda, que afinal tenho filhos e amigos e um trabalho a fazer. (...) Não digam nada (...) da minha vida sei eu.

(LYA LUFT,1989)

O processo de luto é uma transição gradual de ajustamento a um mundo alterado por uma ou várias perdas significativas, no qual os enlutados integram 
gradualmente as mudanças decorrentes destes lutos a uma nova percepção de mundo. No momento em que nos deparamos com a ausência do objeto de amor, buscaremos em nosso repertório estratégias de enfrentamento para lidar com a falta que a perda deste nos faz (coping). Neste processo, deparamo-nos com os chamados fatores disposicionais que podem ser descritos como vulnerabilidades potenciais (fatores de risco) ou forças (fatores de proteção).

Em toda perda é possível identificar estes fatores facilitadores (forças ou fatores de proteção) assim como os que podem dificultar (vulnerabilidades potenciais ou fatores de risco) o processo de elaboração do luto (PARKES, 2009), dentre os quais podemos destacar, por exemplo: o tipo de perda, o momento do ciclo vital no qual esta perda ocorre, se há perdas múltiplas, o histórico anterior de perdas e a presença - ou ausência - de apoio da família e/ou rede de apoio. Em nosso estudo, podemos, de antemão, apontar dois fatores de risco importantes e comuns a todos os participantes: todos vivenciaram múltiplas perdas e tiveram, dentre estas, um membro da família desaparecido após as fortes chuvas que abalaram a região em 2011.

Ao pensarmos nas vulnerabilidades diante do processo de elaboração das perdas, temos inicialmente o fato de alguns entrevistados terem estado fisicamente presentes nos locais dos desabamentos ocorridos principalmente na noite do dia 11 de janeiro. Em meio à confusão vivida por todos os participantes que sofreram perdas em decorrência das chuvas na região, podemos ressaltar que, para os que conseguiram sobreviver aos desbarrancamentos, sentimentos de medo, terror, compaixão, tristeza e impotência foram instantâneos e intensos e todos se sentiram muito impactados pelas cenas vistas e vividas:

Você começa a ver que a chuva não para, tem lama pra todo lado, gente gritando, os animais também tentando sair de lá, criança chorando, tudo uma bagunça e não sabe nem pra que lado corre... e tem medo de tentar ajudar e acabar atrapalhando, fica querendo pegar tudo que vê pra dar pra quem tá perto e também tá vendo tudo desabar... muito triste... gente morrendo, gente que você via todo dia no mercado, na rua, e gente de idade com dificuldade... acho que tinha gente pensando isso de mim também, né?Depois que você percebe que também está correndo pra se salvar e salvar sua família, que tem medo de morrer também e que tem gente vendo isso e tá te ajudando a sair dali do mesmo jeito que você está ajudando os outros... é assim, você ajuda e é ajudado... (Cândido, 53 anos) 
Bate um desespero ver aquilo tudo caindo, chovendo toda hora, e os vizinhos preocupados em pegar as coisas mas não dá tempo de pegar nada... você quer é pegar a casa toda... um cheiro de sujeira, um corre corre pra não ficar ali quando tudo for pro chão... medo de morrer não, medo de ver gente morta eu tive... e a gente vê porque morreu muita gente dali de perto mesmo... e não perdoa ninguém, tem criança, moleque, idoso, quem estivesse no caminho do barranco... não sei nem como consegui sair de lá antes de cair tudo e não fiquei lá, mortinha junto com o resto do pessoal do bairro... eu nem sei quanta gente morta eu vi naquela noite, mas eu sei que é muito sofrimento misturado das pessoas que estavam ali perdendo casa, móvel, parente, tudo ao mesmo tempo... (Suely, 39 anos)

Você sabe que precisa sair, que quer viver, mas e as outras pessoas? Merecem também! Olha aquela quantidade de gente machucada, com medo de cair no barro, com machucado, ou com medo da água mesmo porque nem todo mundo sabe nadar, e a correnteza é barrenta, cheia de lixo, não sabe se vai te afogar ou te afundar... e aí você quer ajudar, mas não sabe como, tem que continuar fugindo, sem levar nada, tem que correr pra se salvar e deixar pra depois pra pensar em quem ficou pra trás... sente um medo mas também tem que pensar na família, nos filhos, em tudo... nessa hora é muita coisa na cabeça... (Emerson, 37 anos).

Já entre os participantes que não estiveram presentes no local - mas também tiveram suas casas interditadas parcial ou totalmente - os sentimentos de impotência e tristeza se intensificaram com a ideia de que, se estivessem presentes, haveria tempo para recuperarem objetos (em particular, os objetos de valor sentimental como fotos e documentos). Não estar presente foi, do ponto de vista dos participantes, ser privado de ter contato pela última vez com algo que lhes era caro e que constituía parte de suas histórias.

Imagina você sair todo dia pra trabalhar, levar filho na escola, ficar naquela rotina pra dar o melhor pra sua família e, de repente, chega na sua casa mas ela não existe mais? Tinha tanta coisa lá dentro que era importante, coisinhas que a gente foi comprando com tanto sacrifício e, de repente, não tem nada mais no lugar... eu tinha que ter chegado mais cedo quando eu vi que tava chovendo (choro), mas como eu ia saber? As roupinhas das crianças, não sei... eu só queria estar na minha casa...eu sei que as coisas não iam conseguir ser todas tiradas dali, mas eu sei que algumas coisas que eu amava iam sair de lá comigo, eu sei que iam! Tem sempre aquelas coisas que a gente sente mais carinho, e eu não estava lá pra separar nada meu que hoje não tem como recuperar... porque eu não tava em casa? Sempre me pergunto isso... (Mônica, 42 anos)

Eu de férias, passeando com a família e vejo tudo aquilo na TV... desesperei e corri pra cá... daí você chega em casa e não tem nada lá? Gente, meu coração parou! Nada, nadinha! Eu falei pro Lucas na hora: "Nossa vida acabou, marido!" porque é o que você pensa na hora... como eu podia estar lá longe e minha casinha 
ali, sendo levada pela chuva? Olha, não sobrou um pedacinho pra contar história! Mas se a gente não tivesse ido viajar podia ter visto que aquilo ia acontecer, ia tirar as coisas... a casa não ia aguentar não porque tava chovendo muito, mas ia dar pra tirar uma coisa ou outra...as coisas de casa a gente nem liga tanto, sabe, tipo os pratos, panelas, toalha, sei lá, isso não importa, mas as coisas que a gente tem de especial a gente podia ter tirado pra fora e ai o povo ia ajudar a descer com elas pra baixo... agora acabou tudo... (Luzia, 32 anos).

Eu sempre penso se a gente não tivesse saído de lá, de repente a casa ainda estava direitinho, o lugar dela... o pessoal da Defesa Civil fica mandando você sair, mas você quer cuidar da sua casa, da sua vida, e não tá vendo cair nada... depois quando você vê, realmente era um perigo fica ali, mas minha casa e minhas coisas tudo estavam lá... quem sabe se a gente não tivesse ficado dava pra fazer um rejunte aqui, outro ali, né? Eu fico me perguntando se não tinha condição mesmo de consertar as coisas... Quem garante que tudo ia cair como eles disseram? Eu não acho justo, já que a casa ainda estava de pé, a gente ser enxotado de lá pelo bombeiro, que eles tinham que deixar a gente pelo menos pegar as coisas mais importantes, pra ficar mais fácil suportar ter perdido a casa... (Hortência, 37 anos)

Sentir-se responsável pelos eventos traumáticos ou crer que sua sobrevivência contribuiu para a morte de outros membros da família ou da comunidade pode ser um fator altamente angustiante e insalubre para os entrevistados. Sentimentos como tristeza e inconformismo acentuados diante de perdas abruptas e inesperadas são esperados e podem ser intensificados, como vimos em nossos relatos, pela chamada culpa do sobrevivente (KRISTENSEN \& FRANCO, 2011), que também se configura como outra vulnerabilidade no processo de restabelecimento emocional dos envolvidos.

Nos casos em que os participantes não estiveram presentes em suas casas quando estas desabaram, esta ausência dificultou ainda mais o processo de elaboração das várias perdas vividas, pois, segundo os relatos, é como se não presenciar os eventos houvesse tornado a experiência menos "real", ou até mesmo como se não fosse possível processar o luto já que não testemunharam as casas no momento em que estas ruíram. Apesar de constatarem a perda concretamente ao verem os soterramentos e todo o entorno devastado pelas chuvas, a imagem não parece abarcar o misto de sentimentos presentes nesse momento; tristeza e culpa invadem os participantes. 
Em situações como as de desastre, mesmo quando estamos de posse de todas as informações ou quando temos acesso aos locais atingidos, nosso lado emocional ainda prevalece sobre o lado racional, e sentimo-nos responsáveis, mesmo que conscientemente saibamos que nossa presença em nada mudaria o curso da História (VALENCIO, 2010).

A transferência destas pessoas para abrigos temporários ou para casa de familiares também se mostrou um fator de risco para a saúde de nossos entrevistados, já que nessas moradias temporárias relatam sentimentos de desconforto e insegurança para exercer suas funções regulares, impossibilitados assim de, aos poucos, retomarem o controle de suas vidas - fator decisivo para a reestruturação individual e familiar após tantas perdas vividas (CASELATTO, 2005). Para nossos entrevistados, não retornar ao lugar em que residiam foi altamente desorganizador e gerou infelicidade, ambivalência e desesperança.

Morar na casa dos parentes é uma benção porque você não tem pra onde ir, mas é uma provação porque nada ali é seu, tudo tem que ser de todo mundo, mas você sabe que todo mundo que vem primeiro são os donos da casa e não você e seus filhos... você quer dar o melhor pros seus filhos e vê que não pode nem deixar eles escolherem onde dormir, o que assistir na televisão, não tem mais opinião... vida amorosa com o marido então, nem pensar! Acabou tempo seu, o tempo é só de trabalhar e ajudar a pagar as despesas que você está fazendo na casa dos outros e dá-lhe sentir falta da sua casa... quem é que quer ficar dependendo dos outros pra tudo? Eu sei que é um favor, que todo mundo ama ajudar minha família, mas não é bom ter um batalhão de pessoas morando na sua casa sem ter dia pra sair porque não tem onde morar...eu sinto que as pessoas não ficam a vontade e eu também não fico, é uma situação que ninguém acha boa... (Luzia, 32 anos)

Tem coisa pior que morar no abrigo? Nada é mais humilhante do que isso! Além de não ter mais nada seu, ainda tem que ver gente empurrando suas coisas, roubando, pegando emprestado e só devolvendo depois, ou até mesmo sujando suas coisas e você não pode reclamar porque tá ali de graça... parece que tem alguém que está te fazendo um favor, mas eu tinha minha casa, minha vida, não sou um homem encostado e não gosto dessa sensação de que a gente tá ali sem perspectiva de ir embora... tem coisas que não tem preço mesmo, porque se eu pudesse, jamais estaria colocando minha família numa situação dessa, uma vergonha! Fica a impressão de que eu não quero sair dali ou coisa do tipo, mas como eu vou sair dali com a minha família se eles prometeram que a gente ia ter moradia e até agora nada?É uma situação que ninguém sabe resolver e a gente sabe que precisa do nosso canto pra viver em paz, pra ser feliz com quem a gente ama... (Sérgio, 49 anos). 
Imagina um homem da minha idade tendo que voltar a morar com a mãe? Mas aí eu penso que se eu não tivesse minha mãe, o que ia ser de mim? Então é aquilo... você se acostuma com o que tem, tenta reclamar pouco mas também não dá mais pra não querer seu espaço... como eu pago pensão pras crianças, eu ainda não posso sair de lá, mas assim que der vou achar um cantinho pra mim porque não quero sobrecarregar a "velha" e também quero viver minha vida, entende? eu quero casar de novo, encontrar alguém pra ficar comigo e morando com a mãe isso complica, não dá pra fazer as coisas que eu fazia quando eu morava sozinho, entende? Eu não posso ficar morando com ela até ela morrer e eu herdar a casa ou sair de lá pra ir pra debaixo do viaduto, porque é só o que sobra pra gente que passou por tudo isso... (Emerson, 37 anos)

A falta de autonomia, de privacidade, o desejo de ter uma moradia própria, a esperança de dias em que a família vá se reunir de novo em um local a que possam se referir como lar são sentimentos presentes na fala de todos que tiveram que abandonar suas casas durante as chuvas, e esta falta de um local de referência, de segurança e proteção pode levar a uma inibição ou mesmo adiamento dos sintomas, tendo em vista que estas pessoas não possuem nem mesmo um espaço onde possam expressar seus sentimentos de forma segura. Aqui vemos novamente a questão dos lutos não reconhecidos e inibidos, pois as pessoas sofrem pela perda da casa, mas ao serem abrigadas por instituições ou familiares, sentem-se pressionadas (ou compelidas) a não falar mais sobre a dor e o sofrimento que esta realidade lhes traz pois isto poderia ser entendido como ingratidão ou autopiedade (VALENCIO ET AL., 2005).

Sabemos que moradias temporárias podem ser desconfortáveis, apertadas e pouco acolhedoras, especialmente se estas são espaços improvisados destinados a servir de acolhimento provisório (estadia que, em muitos casos, se prolonga de tal forma que acabam se tornando permanentes). Não é incomum que nesses ambientes coletivos como abrigos o indivíduo não possa falar de forma aberta sobre suas dores e angústias ou mesmo possa se expressar; nem sempre o sujeito terá de seus companheiros a receptividade que lhe permita ventilar e validar seu luto, apesar de coabitarem nesses mesmos locais com outras pessoas que compartilham de tantas perdas semelhantes. Isso ocorre também porque a forma de expressão do luto é peculiar e individual, e pode não ser compreendida e aceita pela coletividade (WORDEN, 1998), o que dificulta ainda mais o processo de elaboração. 
Outro aspecto a ser levantado diz respeito à religião. Perdas abruptas e inesperadas intensificam as reações de luto, principalmente nos casos onde mortes ocorrem de forma violenta ou em circunstâncias pouco conhecidas (assim como nos casos de desaparecimento decorrentes de desastres), bem como nos casos de perdas múltiplas. Perdas de pessoas queridas e objetos de amor importantes levam os enlutados a questionarem as diversas certezas que temos em nossas vidas inclusive nossas crenças religiosas - especialmente porque diante do falecimento de um ser amado e de outros lutos consecutivos ou concomitantes nosso mundo presumido é fortemente abalado (PARKES, 2009).

Diante da violência e da devastação da catástrofe da Região Serrana, um dos pontos levantados por nossos entrevistados foi justamente o papel da fé e da instituição religiosa neste processo de enfrentamento, e como não só a perda de familiares (mortos ou desaparecidos) mas também as demais perdas sofridas levou-os a questionar as causas e razões para tanto sofrimento, ora demonstrando raiva e indignação, ora consternação ou mesmo resignação frente aos desígnios divinos:

Eu sou muito temente a Deus, mas a gente fica numa raiva nessa hora... a gente acredita na força e no poder Dele, e não pode questionar os desígnios que Ele tem pra gente, mas eu não entendo como que meu pai e minhas duas irmãs foram arrancadas assim da nossa vida, do nada, sem que a gente pudesse se preparar, se é que alguém consegue se preparar para uma coisa dessas... e como que Ele só me devolveu as meninas? Cadê meu paizinho, aquele que me colocou no mundo, que me chamava de princesa? Deus me deu ele todo bondoso pra me tirar desse jeito? Dá uma angústia, uma ira nessa parte! Eu não sei, acho que só Ele sabe que provações a gente pode suportar, mas é uma cruz pesada essa nossa (choro). Não gosto de questionar, mas tenho meus dias de revolta com essas provações que Ele colocou no meu caminho... (Bárbara, 25 anos).

Eu tive muita dificuldade pra aceitar que a gente ia comprar um caixão pra enterrar roupa... eu queria ver ela... quando a gente era criança foi criada tudo junto, era uma irmã pra mim, e aí alguém fala que ela morreu mas ninguém me dá nada? Não é possível não sobrar nada de uma pessoa inteirinha! E aí vem um pastor e diz que a gente não pode se apegar na matéria e eu sei que o corpo da gente é só uma casca para as ações de Deus, mas o corpo também é sagrado e deve ter seu destino final... onde ela tá? Onde ela tombou? Que Deus tenha misericórdia dela na hora que ela padeceu porque pra não sobrar nada a gente só pensa que foi dolorosa a ida dela (choro). Aí ainda tem que aguentar todo o resto de coisas perdidas, ficar sem casa, tanta gente perdeu a família toda e a gente não entende o porquê disso... (Luzia, 32 anos). 
Quem tem fé sabe que é difícil abalar, mas quando tem um mundo de gente morrendo, sofrendo, correndo pra salvar seus filhos, suas coisas, na hora vem um sentimento de medo de ter sido abandonada por Ele... Deus que me perdoe, mas eu tive muita raiva Dele, muita mesmo... como que uma coisa dessas pode acontecer com tanta gente de bem, que trabalha, que sofre todo dia só pra sobreviver? Mas a raiva vai passando, mesmo se a gente não entende porque teve que ser assim. Se eu tivesse como responder pra mim mesma o motivo disso tudo, talvez eu ficasse menos triste, mas é assim, tem que aceitar o que não podemos mudar, tem que ter força pra começar tudo de novo, erguer a cabeça e lutar muito, porque ficar parado não dá... eu entendo assim... (Olímpia, 43 anos).

Para alguns participantes, no entanto, poder suportar as provações decorrentes do evento catastrófico foi um importante medidor da força interna de cada um; é como se, a partir de uma situação caótica e de perdas múltiplas, o ser humano estive sendo testado pelo Criador em suas crenças, e nesse momento seria possível provar - ou não - se sua fé é resistente e consistente:

Eu acredito que todo homem e mulher que estava ali naquele dia tinha que passar por tudo isso pra saber que Deus existe, mesmo que a gente tenha chorado muitas mortes de muita gente querida... ninguém cresce sem dor, não é o que dizem? Nosso Pai sabe que ninguém carrega uma cruz mais pesada do que pode suportar, e nem nós podemos reclamar de ser submetidos às provas Dele, e essa foi uma dura de suportar, mas tem que seguir em frente. Toda dor é uma forma da gente se apegar mais a Igreja e aos colegas, é com eles que a gente se apega nessas horas, fica mais perto de pessoas que você nem tinha tanto contato antes, fica mais solidário e descobre com quem pode contar de verdade, e tem que ter fé todo dia pra não se perder nessa dor... (Gerson, 49 anos)

Tem coisas que a gente não compreende na hora, mas tem que confiar no que Deus coloca na nossa vida, sempre! Eu tenho fé e acho que as dificuldades podem fazer a vida da gente ser mais produtiva, e hoje eu me dedico mais a ajudar os outros do que antes, e isso graças ao que aconteceu... tem males que vem pra bem, eu acho...nem sempre é fácil saber o que fazer, a gente fica com muito medo e sente as dores do corpo e da alma, mas tem também uma força que vem Dele, e é assim que a gente abre caminho pras coisas novas que vão entrando na nossa vida... claro que a gente sente falta das pessoas que morreram, de quem não está mais entre nós, até dos lugares que ficaram destruídos pela chuva, mas tem que ser assim, pra tudo fazer sentido, pra darmos mais valor as pessoas e as coisas que fazem parte do nosso dia a dia... (Verônica, 28 anos)

Ninguém sabe o que Deus planeja, mas temos que seguir os planos Dele e ser tementes ao que ele comanda, mesmo quando a gente sente que está sendo duro. Eu acredito que essas chuvas vêm testar a gente, nossa fé, e tem que ser assim, inabalável, porque se eu e minha família sobrevivemos é porque assim Ele quis, e vamos seguir levando a Palavra Dele sempre. Eu e minha família sabemos que todo dia é dia de agradecer por termos sobrevivido aos dias que passamos, $e$ 
não creio que tenha sido em vão, até porque fazemos de tudo para provar que merecemos estar vivos, mesmo não sabendo porque Deus nos escolheu para permanecer por aqui e outros morreram naqueles dias... é triste ver que muitos tombaram, mas nossa compreensão é pequena perto do que Ele determina para nossas vidas... (Osmar, 51 anos)

Vemos que a fé pode não só ser abalada, mas também fortalecida a partir de eventos como os ocorridos na Região Serrana, estreitando os laços entre o sobrevivente e suas crenças religiosas, recurso que pode ser muito reconfortante e que, ao agregar outros membros da comunidade atingida, torna possível resgatar um ambiente de ventilação e validação coletiva das perdas vividas. Trocar experiências e pensamentos com pessoas com quem se comunga é revigorante e ajuda a restabelecer a fé não só na religião, mas também em dias melhores para si e para os demais atingidos pela tragédia.

Por outro lado, em alguns casos, a fé pode servir como uma espécie de sustentáculo que ajuda a explicar o “inexplicável” - como na fala de Verônica, quando está ressalta: “... tem que ser assim, pra tudo fazer sentido”. Para alguns entrevistados, por se tratar de um desastre natural, não é possível encontrar respostas que sustentem a explicação para tantas mortes e desgraças, e apenas uma força maior - Deus - poderia justificar estas ocorrências; consequentemente, é a Ele que devem recorrer para suportar as dores decorrentes desses eventos. Sob este ângulo, a religiosidade e a espiritualidade são consideradas forças ou fatores de proteção pelos entrevistados, mas devemos estar atentos ao risco destas crenças tornarem-se resignação e escamotearem uma negação em relação aos agentes causadores da tragédia e da não responsabilização dos envolvidos.

Outro fator de risco identificado em nosso estudo está relacionado à idade dos mortos e desaparecidos durante as chuvas na região. Podemos perceber que, no caso de falecimentos de crianças e adolescentes, a dor da perda foi intensa e sentimentos de culpa, tristeza, impotência e indignação foram mais presentes, aumentando a carga de sofrimento experienciado por nossos participantes.

Eu sabia que muita gente tinha morrido naquele dia, mas daí a você ver aquela quantidade absurda de crianças ali, soterradas, levadas pela água, indefesas e sem a menor chance de sobreviver, aí você não aguenta... é muita tristeza no coração de quem é pai e mãe, que sabe o quanto a gente ama os filhos da gente e aí se sente assim, perdido, como se o mundo fosse acabar depois de uma 
coisa dessas... eu perdi dois sobrinhos, uma tristeza que eu nem sei te explicar, daquelas que machuca dentro da gente... tudo menino novo, e você não quer acreditar que aquilo é verdade porque eles ainda tinham a vida toda pela frente... (Gerson, 49 anos)

Eu não tinha ideia de como dói perder uma pessoa assim, desse jeito, mas o que mais me dói mesmo é saber que minha sobrinha tava lá, sem saber nadar, sem saber se defender, e que ela pode ter ficado machucada e sofrido antes de morrer (choro). Ela só tinha 12 anos, entende? É uma vida toda que ela ainda ia viver, se divertir, namorar, casar, ter filhos, ser feliz... aí vem uma chuva dessas e leva uma criança indefesa, ingênua, uma menina mesmo... ela era linda, cheia de vida, só vivia sorrindo, bem coisa de criança mesmo e aí você só fica com essa dor no peito, uma vontade de chorar porque a gente sabe que ela seria uma mulher incrível... (Flávia, 33 anos)

Não tem como eu te dizer o que eu senti quando eu vi que minhas irmãs tinham morrido... a mais nova estava com 15 anos e eu fiquei completamente alucinada na hora que eu recebi a notícia... meu irmão no hospital, minha outra irmã de 17 e meu pai não tinham sido encontrados, eu pirei! Quando você pensa nas pessoas que você gosta, você quer cuidar, abraçar, mimar, ainda mais quando é irmão caçula, né? Eu era confidente delas, por ser mais velha, casada, já sou mãe e tudo, e elas vinham sempre falar comigo dos meninos que elas conheciam, que elas queriam sair e meu pai não deixava... era bem aquela coisinha de adolescente, mas estavam ficando cada vez mais bonitas, eram super inteligentes, na idade mesmo de aprontar mas também muito responsáveis dentro de casa... é uma coisa que a gente não entende, que quer voltar no tempo pra mudar... devia ter uma lei que proibisse gente nova de morrer porque tá errado, tem que viver tudo que tem direito! (Bárbara, 25 anos)

A perda de um ente querido sempre traz dor e sofrimentos aos enlutados, mas quando o falecido é uma criança ou um adolescente, abre-se uma ferida que parece ser sentida de forma mais profunda, pois sua morte representa a quebra da ordem entre as gerações, uma ruptura de um ciclo que acreditamos ser previsível, correto e compreensível. A ordem natural da vida é completamente invertida e os sonhos e projetos que depositamos nos mais jovens são destruídos, o que é difícil de processar (KOVÁCS, 1992).

Tendo em vista que a morte de crianças e adolescentes é um fator de risco significativo para a elaboração do luto, podemos afirmar que esta perda pode ser ainda mais devastadora se o falecido for um filho. Entre nossos entrevistados, dois pais - uma mãe e um pai - viveram essa triste história e, em seus relatos, a marca de um sofrimento impensável e indescritível. 
Nossa, meu coração partiu no meio! Meu filho querido, um pedaço de mim que eu nunca mais vou ver (choro). A gente cria um filho com tanto carinho, com amor, batalha pra dar educação, ensinar tudo de certo na vida e por causa disso mesmo ele resolve ajudar todo mundo e morre ajudando... meu filho nasceu pra ser um anjo, isso é verdade, mas não podia ter ido tão cedo, sem nem viver as coisas que ele sempre sonhou... não tá certo, não pode! E pior: cadê ele? Ninguém me tira essa agonia de dentro do peito, da gente nem ter encontrado ele pra se despedir, deixar ele descansar em paz num lugarzinho só pra ele... mas eu sei que ele morreu ajudando as pessoas que ele viu que tavam precisando dele, que eram mais necessitadas... mas e eu, como fico sem ele? Eu morro de saudades do meu menino, de tanta coisa que não dá nem pra falar... (Nadir, 50 anos)

Eu sempre fui um pai muito presente na criação dos meus filhos porque eu sempre quis ser pai. Pra conseguir isso, eu trabalhava de dia mas sentava todo dia a noite com eles pra ver a lição de casa, ajudava nos trabalhinhos, corria pra chegar o mais cedo que eu podia pra assistir um jogo junto com os moleques e pedia pra eles nunca esquecerem de que a família da gente é a coisa mais importante na vida. Como é que eu não vi que o Guga tinha ficado pra trás? Pensa numa pessoa que não se conforma... esse sou eu! Pra falar a verdade, eu sempre pego as roupas dele que a gente guardou e tento lembrar do cheirinho, da risada gostosa assistindo desenho, do jeitinho dele jogar bola na rua com os outros moleques... eu só peço a Deus e a ele: eu sinto muito, meu filho, papai não podia ter deixado você sozinho numa situação daquela (choro) (Sérgio, 49 anos)

A morte de um filho rompe com a ordem natural na vida e, quando esta ocorre, surgem sentimentos de culpa e desespero por não terem conseguido manter os descendentes em segurança, papel que se julga próprio dos genitores. Assim como quando a criança é pequena e precisa sentir-se amparada pela figura de apego, os pais consideram-se responsáveis por garantir que a vida dos filhos siga o curso normal do tempo e, durante seu crescimento, depositam nestes suas expectativas e projetos de um futuro feliz e promissor. Perder um filho é considerado por muitos a pior experiência em vida que se possa ter e, para elaborá-la, os pais (ou figuras de referência) precisarão usar todos os seus recursos internos pois não ocorre apenas a perda de outro, mas efetivamente a perda de parte de si (CASELLATO, 2005).

Para os dois entrevistados que viveram esta experiência, foi mais do que a perda de um ente querido: foi a perda do papel de pai e mãe daquele que agora está se foi e, para agravar ainda mais este luto, seus corpos nunca foram localizados. 
Se perder um filho já se apresenta como uma vivência de difícil elaboração, ao não concretizá-la, os pais ficam mais fragilizados, desamparados, imersos em uma dor sem fechamento. A impossibilidade de materializar a morte dos que dele nasceram parece não concluir esse ciclo de nascimento/falecimento e os pais sentem-se desprovidos de algo que lhes dê sentido diante de uma dor tão dilacerante.

Assim como a perda de filhos rompe com a estabilidade e com a ordem natural da vida, a perda de genitores ou figuras maternas/paternas também agravou o estado emocional de nossos entrevistados. Apesar destes serem mais velhos (alguns já idosos), a forma como a morte ocorreu tirou dos filhos a oportunidade de oferecerem aos pais as honras que consideravam justas.

Eu queria entender como pode uma pessoa que viveu uma vida inteira, trabalhou a vida inteira, morrer assim, de uma hora pra outra, sem nem mesmo a gente saber como ele se sentiu no final... aí demorou pra descobrir onde tava, $e$ quando achou a gente não podia ver! Meu pai, que sempre cuidou de mim, me deu tudo que eu sempre quis, foi um homem e tanto e eu nem pude me despedir dele direito! Você conhece, sabe que ele era um cristão fervoroso, que ia querer receber o carinho da família, dos amigos... Eu acho que não tem como a gente se conformar com uma coisa dessas, é um desrespeito por tudo que ele me fez durante a minha vida toda... amor de pai a gente não tem como medir, eu sei porque eu sou mãe, e não tem como voltar pra trás e mudar o que aconteceu... (Ariane, 37 anos)

Eu senti uma pontada no peito quando me disseram que minha mãe tinha morrido, fiquei sem rumo mesmo... eu quero entender pra poder me sentir melhor, mas não tem como! Minha mãe era minha melhor amiga, uma pessoa guerreira, batalhadora, me criou sozinha porque meu pai me abandonou quando eu ainda era bebê e eu cresci tanto com as coisas que ela me ensinou... não importa que as pessoas digam que ela já tinha vivido tudo que tinha pra viver porque a gente sempre tem mais coisas pra viver, né? Gente velha não é gente morta, só é mais velha... Ela podia ter sido bisavó, podia ter saído mais com as amigas da Igreja, podia ter feito um monte de coisas que agora não vai mais fazer porque essa maldita chuva levou todas essas chances embora... eu sei que as pessoas querem me consolar, mas é difícil aceitar que uma pessoa tão maravilhosa como ela tenha partido assim, sem nem se despedir... (Hortência, 37 anos)

Minha avó me criou com a minha tia e quando eu soube que ela tava desaparecida eu pensei que fosse morrer porque já tinha sido difícil quando eu perdi minha avó que era tão especial pra mim e aí ela se foi assim, num sopro! Quem na vida tem a sorte que eu tive, de ter sido criada por duas mulheres maravilhosas, que me deram todo amor, carinho e educação? Tanta gente me perguntava porque eu não tinha pai e mãe e eu sempre respondia: 'Mas eu tenho duas mães" e ninguém entendia, mas era isso, minha vida foi assim, com duas mulheres incríveis que me ensinaram a ser a mãe que eu sou hoje. Pra falar a 
verdade, minha tia era mais que uma mãe, era minha amiga porque nossa diferença de idade era bem menor e ela era muito ativa na comunidade, sempre ajudando todo mundo e eu admirava ela demais que não dá pra substituir esse espaço que ela ocupa no meu coração por nada nem ninguém! (Flávia, 33 anos)

A morte do(a) genitor(a) foi sentida como um duro golpe por nossos entrevistados pois, apesar de seguir a ordem natural do ciclo vital - segundo o qual os mais velhos partem antes dos mais novos - a maneira abrupta e inesperada com que ocorreram os falecimentos tornou mais difícil a elaboração destes lutos. Em geral, os pais são figuras importantes que servem como referência - mesmo quando já somos adultos - de cuidado, afeto e respeito. Com eles aprendemos valores e transmitimos aos descendentes a história da família, e lutos como estes, não elaborados, podem atravessar gerações (SELIGMAN-SILVA, 2008). Ao perdê-los, sentimo-nos responsáveis por garantir que lhes sejam prestadas as últimas homenagens, de forma não só a nos despedirmos mas também agradecerlhes por tudo que nos ensinaram ao longo da vida; quando isto não ocorre, podemos nos sentir em dívida com eles, gerando ainda mais sentimentos de culpa e remorso.

Como podemos perceber, a perda de um membro da família em decorrência de um desastre gerou nos enlutados sentimentos de dor, impotência, tristeza e angústia (PARKES, 2009). Agravando ainda mais este quadro, temos entre nossos entrevistados casos nos quais mais de um membro da família padeceu durante a tragédia, aumentando o risco de um quadro de luto complicado. Perdas múltiplas são avassaladoras, especialmente quando as perdas humanas são numerosas e irreversíveis.

Eu jamais imaginei perder meu irmão desse jeito, mas o pior é que toda família dele morreu junto com ele... irmão a gente ama desde criança, a cunhada a gente aprende a amar como se fosse uma irmã e os meus sobrinhos eram tudo pra mim, como se fossem meus filhos mesmo... aí você vê, eu perdi os quatro e nem tive a chance de ajudar eles! Eu não acho que tenha sido justo porque sinto uma falta do tamanho do mundo, mas também fico pensando na dor que ele ia sentir se ele tivesse ficado vivo... como que eu posso saber também como aconteceu tudo se acharam minha cunhada e meus sobrinhos e ele não? Eu sofro com isso ainda hoje e minha família percebe, não tem como! Meu filho mais novo é o que mais sente porque ele era muito pegado nos primos, e eu não posso mudar o que aconteceu... ninguém pode! (Gerson, 49 anos) 
Eu sinto que uma parte de mim morreu aquele dia, não é nada igual como era... meu pai era meu ídolo, minhas irmãs eram minhas parceiras, meu mundo foi abaixo junto com a lama toda daquele dia... mas eu tenho uma filha pequena, que precisa de mim e um marido que me ama porque senão não ia aguentar (choro). Pra cada dia que eu vivo, é um dia que eu chego mais perto de encontrar eles de novo, né? Não adianta, não sou a mesma pessoa e não sinto a mesma coisa pela vida depois de tudo que aconteceu... o medo que eu tenho agora é de perder minha filha que é tudo pra mim! Eu era muito ligada na minha família, mesmo não morando mais com meu pai e meus irmãos, mas sempre estava muito próxima deles e depois que eles morreram eu só penso nela, pra me dar forças pra continuar porque eu sinto uma saudade que dói demais... (Bárbara, 25 anos)

Foi tudo tão difícil naquela época e ainda hoje eu sinto uma dor que é imensa... perder um pai e uma mãe no mesmo dia é horrivel, e ainda perder dois irmãos é uma coisa inexplicável... eu chorei tanto, pedi forças a Deus, quis até sumir por um tempo, mas eu também tenho minha família e não posso tirar dos meus filhos tudo que sempre tive dos meus pais... eles me deram tanto carinho, tanto amor, batalharam pra gente ter uma vida boa, digna e por isso eles mereciam ter tido um enterro digno também... meus irmãos eram meus camaradas, apesar da gente ser mais próximo quando a gente era criança, mas não muda o amor... quando a gente envelhece, vai vendo que os pais e os irmãos também estão envelhecendo, mas nunca imagina que eles vão morrer assim, numa tragédia... sempre imaginei meus pais ficando bem velhinhos juntos, na varanda de casa, meu pai resmungando, minha mãe costurando e agora nada disso vai acontecer, meus irmãos e eu fazendo churrasco na casa deles e levando as crianças pra brincar no quintal que nem quando a gente era criança e agora acabou tudo isso... (Ronaldo, 35 anos)

A família sente a saída de um de seus membros como uma crise, pois esta exige que todo o sistema se reorganize em decorrência desta ausência, e se esta saída é irreversível - como ocorre nos casos de falecimento - o desequilíbrio pode ser ainda maior. Quando mais de um dos membros se faz ausente, a intensidade da desorganização dos papeis que devem ser redistribuídos entre os familiares remanescentes é intensa e angustiante (o que se torna ainda mais complexo se esta perda é abrupta, violenta e/ou misteriosa (WORDEN, 1998)).

Concluímos que, diante de tantas perdas consecutivas, impactantes e desestruturantes, nossos participantes apresentam uma série de vulnerabilidades que podem levar ao desenvolvimento de um quadro de luto complicado pois, além das múltiplas perdas vividas em decorrência do desastre, ainda devem lidar com perdas ambíguas e sentimentos intensos de culpa, impotência, medo, desamparo, insegurança, raiva e inconformismo. 
Para lidar com esse misto de sentimentos, muitos buscaram apoio naqueles que, assim como eles, viveram perdas imensuráveis e de grande impacto na vida pessoal e familiar, na tentativa de resgatar algo que pudesse lhes proporcionar reconhecimento e, posteriormente, a chance de reconstrução em meio a tanta destruição. É na interface dos discursos dos inúmeros enlutados que a história de cada participante se construiu, fazendo surgir em meios aos tantos relatos uma história compartilhada de força da união do grupo.

\subsection{MEMÓRIA INDIVIDUAL E MEMÓRIA COLETIVA}

Uma parte importante do processo de cura comum é ter uma história validada e tornando-se uma parte da história coletiva que emerge após uma tragédia.

(KLINGMAN \& COHEN, 2004)

Nossa memória é construída socialmente e armazenamos em nosso repertório tanto histórias que nomeamos como individuais como também de nossa relação com a coletividade. Neste processo de construção de nossas memórias, não só agentes internos operam, mas também compartilhamos informações com os grupos nos quais estamos inseridos e, estes dados formam, conjuntamente, os perceptos e imagens que elegemos das situações cotidianas e os quais traduzimos em momentos que se tornam lembranças de nossas vivências.

Em uma situação de desastre, nossas lembranças, assim como nos momentos cotidianos, serão repletas de imagens individuais, mas estas são sempre permeadas por nuances dos discursos dos outros que, direta ou indiretamente, nos fornecem informações sobre as cenas ocorridas nos dias que, por vezes, desejamos trazer a tona em nossa memória. Grupos devastadoramente afetados por desastres e cujas circunstâncias adversas vividas exijam grandes esforços - em especial nos casos em que os enlutados são também sobreviventes da catástrofe possuem uma experiência comum que se traduz em representações complementares sobre o acontecimento vivido até o ponto em que passam a constituir um discurso coletivo (VALENCIO, 2010). 
Já vimos que, nos momentos iniciais após o desastre, alguns entrevistados apresentaram certa dificuldade em rememorar os eventos ocorridos, principalmente pela desorganização própria às situações catastróficas. No entanto, com a ajuda de familiares, vizinhos, colegas e até mesmo das notícias veiculadas na mídia, os discursos foram sendo completados, e cada sobrevivente pôde formular (ou reformular) sua história sobre o desastre.

A construção individual é fundamental para que o sujeito possa tornar a experiência particular e memorável, em vista da importância deste tipo de vivência na história particular de cada um; no entanto, esta história só existe pois todos estavam inseridos em uma coletividade, a qual também vivenciou os momentos de caos e desordem que cada indivíduo passou naquele início de ano na Região Serrana. Em seus relatos, podemos perceber a importância dos discursos paralelos neste processo de reconstrução da memória individual, o que possibilitou também a criação de espaços de ventilação de sentimentos e posterior validação da experiência.

Eu tive dificuldade de lembrar o que era meu e o que era dos outros, tava tudo misturado que nem a lama. Acho que se as pessoas não tivessem me contado ia até parecer que eu tava mentindo porque certeza mesmo eu não tinha... eu até acho que eu lembrava de uma parte ou outra, mas depois quando você vai conversando com as pessoas é que vai vendo que as coisas foram diferentes... tem história que a gente nem sabe se lembra mesmo ou se está só imaginando, mas aí, quando vai ver, alguém te conta que você tava perto do Fulano, ajudou o Ciclano em alguma coisa ou foi alguém que te ajudou e nem sabia! Isso a gente foi vendo quando pessoal começou a contar as coisas, falando o que tinha acontecido naqueles dias de ponto em ponto mesmo... aí sim teve coisa que fez sentido... (Suely, 39 anos)

Eu lembrava muito da hora que a chuva tinha começado, das crianças correndo quando a gente viu que a casa tava balançando, dos gritos e tudo isso, mas não sabia muito bem de onde vinham os gritos nem nada... aí minha comadre disse que eu fui pegar um dos meninos no colo e só gritava pra ele parar de chorar porque ele tava assustando os 2 mais novos e que naquela hora a gente tinha que ficar junto... imagina que eu me lembro disso, nem de pegar ele no colo eu lembrava! Aí você vê como é importante as pessoas que estão por perto, pra te lembrar dessas horas que nem você sabe o que tava fazendo, pra te dizer que você já fez uma coisa que você jura de pé junto que não fez, pra te dar aquele apoio mesmo numa hora que você nem sabe direito quem é você e como foi parar naqueles lugares que você vai... (Nadir, 50 anos) 
Eu imaginava que tinha falado e feito várias coisas naquele dia, mas depois falando com um amigo eu vi que tinha ficado umas 2 horas só chorando, sem falar nada, olhando para toda aquela bagunça e pensando no que ia ser da gente quando aquilo tudo acabasse... eu olhava sem saber com quem conversar, depois você pergunta aqui e ali e descobre que muita gente falou com você, que você até ajudou e não registrou porque tava no 'piloto automático' naqueles dias... se esse meu amigo não tivesse me dito, não acreditaria que eu fiquei essas 2 horas só olhando o pessoal trabalhando sem saber o que fazer... (Flávia, 33 anos)

A construção da memória coletiva em situações de desastre se dá a partir dessa multiplicidade de discursos que, juntos, formam um todo compartilhado do evento que, se visto apenas em suas partes, não se completa. Esta memória coletiva é um dos fatores contribuintes para o sentimento de pertença, de validação da experiência e posterior movimento de reconstrução tanto individual como familiar e da comunidade, o que corrobora com os apontamentos de Seigmann-Silva (2008), pois os envolvidos, identificados com a vivência, permitem-se experimentar diferentes versões destas histórias e, a partir destes relatos, vão encontrando caminhos para elaborar suas perdas.

Quando a gente começa a ver que ninguém sabia o que estava acontecendo, que as sirenes não tinham tocado, aquela correria toda era pro lado errado da encosta porque o pessoal da Defesa Civil não tinha ainda um plano de escape, a gente percebe que muita gente se machucou e morreu por falta de informação correta... isso eu soube pelos vizinhos, né, porque na hora você não sabe de nada disso e agora a gente cobra uma postura das autoridades porque isso não pode continuar acontecendo! E aí você sabe que quem te ajuda a sobreviver é seu colega, ele é quem tá ali contigo, e que você precisa continuar seu caminho até pra poder retribuir o carinho que recebeu dos colegas e pela família que sobreviveu... (Osmar, 51 anos)

Eu hoje sei quem fez parte daqueles dias de cão que a gente passou e que até hoje a gente ainda vive, e que foram pessoas muito importantes pra que eu e minha família estivéssemos informadas e com acesso a tudo que estava acontecendo lá nos terrenos... eu queria ver se a gente não tivesse amigos, vizinhos, o que ia ser da gente... ninguém sobrevive sozinho pra nada, numa situação dessa então, nem pensar! E tem que reconstruir, tem que continuar em frente porque quem teve tanta sorte agora tem que ter muito que retribuir, e hoje é continuar nossa luta porque esse tipo de coisa não pode acontecer de novo, nem com a gente nem com outras pessoas! Cada hora que você lembra de quanta gente se ajudou, de como as coisas só fazem sentido quando você respeita seus irmãos e ajuda, de coração aberto, porque tem muita coisa que eu só vivi porque eles existem... (Bruno, 25 anos) 
Com certeza esses dias que a gente passou junto de tanta gente que tava no mesmo lugar que as outras pessoas, que tinha perdido família, casa, tudo, é que a gente passa a ver que nunca sofre sozinho, tem sempre alguém pra te dar um ombro e que precisa de uma palavra de conforto também... as vezes na correria do dia a dia a gente esquece que todo mundo tem problemas, mas numa situação dessas, todo mundo se iguala e vive aquele sentimento junto, se encontra na dor mesmo.O pior cego é aquele que não quer ver e se a pessoa do meu lado também está sofrendo, eu tenho mais é que pensar que eu e essa pessoa temos um monte de coisas pra conversas, que a gente viveu coisas ali, pau a pau, e tem gente que até perdeu muito mais coisa do que eu, e por isso eu posso ser também um ombro amigo pra quem tá logo ali... (Zenaide, 44 anos).

A vivência de múltiplas perdas é altamente desorganizadora para os enlutados, mas partilhar esses momentos com a comunidade pode ser, em parte, um alento, já que na experiência de compartilhar dores, angústias e temores, os sobreviventes se identificam, se permitem nomear sentimentos e podem elaborar novas formas de organização com vistas à reconstrução do grupo (SELIGMANSILVA, 2008).

Foi perceptível também que, ao compartilhar suas histórias, os participantes sentiram-se acolhidos por aqueles que fizeram parte desse momento de suas vidas, que apesar de muito sofrido e instável, foi berço de novas amizades e fortalecimento de laços com pessoas já conhecidas. Um fato curioso, no entanto, é que nossos entrevistados demonstraram ficar muito mais a vontade na companhia de sobreviventes do que quando na presença de pessoas que não tiveram a mesma experiência:

A gente sabe que quando alguém vive uma coisa dessas, só outro que passou pela mesma coisa é que entende a gente... não dá pra falar de toda dor que a gente sentiu se não for com alguém que não tenha perdido nada, não faz sentido... quando você conversa com alguém de outra comunidade, sabe a diferença de tudo que a gente passou naqueles dias... as pessoas até queriam ajudar, mas não entendem bem tudo aquilo... eu sentia uma dor no peito toda vez que conversava com as pessoas sobre isso, mas eu precisava desabafar um pouco, por isso ia sempre procurar minhas vizinhas e o pessoal lá do bairro que tinha por perto porque aí a gente sabia o que um tava falando e podia dar um ombro amigo, um pouco de carinho e esperança pra quem tava na mesma situação que a gente... (Mônica, 42 anos)

Nem todo mundo sabe o que dizer numa hora como aquela, e nunca vai saber porque só quem esteve lá sabe como foi... tem um cheiro, um monte de barulho, tem coisas que a gente viu e que só a gente lembra... claro que a gente conta tudo mais de uma vez pra quem quiser ouvir, mas saber mesmo o que 
aconteceu só aquelas pessoas que estavam ali no meio daquela confusão de gente, de lama e de chuva... eu não sei explicar, mas acho que eu passei uns dois meses só querendo conversar com o pessoal lá do bairro mesmo porque eles entendiam tudo do que a gente tava falando... tem o pessoal do resgate e dos Bombeiros que também sabiam, mas eles estavam lá trabalhando, então não é a mesma coisa... acho que é o tipo de situação que ninguém pode saber até passar por isso, né? (Sérgio, 49 anos)

Eu falei com tudo que era vizinho, amigo, gente das quitandas, todo mundo que tinha perdido alguma coisa naquela chuva, mas vira e mexe vinha alguém da $T V$ ou de outro bairro perguntar e você fala, mas nem sempre quem tá perguntando tá te entendendo, sabe como é? Eu preferia conversar com as pessoas que eu conhecia que estavam na lida diária ali comigo, que tavam buscando os familiares, que tinham perdido as casas, porque assim você sente que quem tá ali quer mesmo saber o que você tá sentindo e não só de curiosidade e nessas horas o que você menos precisa é de alguém azucrinando a sua vida só pra fazer fofoca e mexerico! $O$ assunto é sério, a gente tem direitos, e se for pra não ajudar, pelo menos não atrapalha, não é mesmo? A gente precisa respeitar mais o próximo... (Tereza, 42 anos)

A experiência de troca entre os pares foi de grande valia para os participantes que se sentiram acolhidos e acolhedores, ajudantes e ajudados. Toda vivência passava a ter sentido e significado quando na presença de pessoas que partilhavam dos mesmos sentimentos e lembranças daqueles dias de caos e ruptura. Achar as partes desse quebra-cabeça fez parte do processo de reconstrução, e isto só foi possível na parceria entre os sobreviventes, mostrando que a memória coletiva e o ato de testemunhar pode sim facilitar a integração dos fatos e a validação da experiência vivida.

\subsection{REDE DE APOIO E ENVOLVIMENTO DA COMUNIDADE NO PROCESSO DE RECONSTRUÇÃO INDIVIDUAL E COLETIVA}

Um dos mais importantes processos para a cura é a reunião das pessoas, permitir-lhes reconectar-se, para adquirirem um senso de apoio mútuo e compreensão da normalidade das suas respostas. Elas também necessitam compartilhar suas histórias de sobrevivência. 
Durante um desastre, o nível de desestruturação e desorganização é elevado não só para os atingidos, mas também nos locais das intempéries assim como para as equipes de apoio e de resgate. Nos momentos seguintes a uma catástrofe pluviométrica, meios de comunicação, iluminação e acessos aos bairros atingidos comumente sofrem danos em decorrência das fortes tempestades que se abatem sobre as comunidades. Na Região Serrana não aconteceu diferente: estradas foram bloqueadas; telefones ficaram mudos; encostas desbarrancaram sobre moradias, comércios e demais estabelecimentos; postes, pontes e vias de ligação caíram, deixando algumas localidades completamente isoladas.

Neste primeiro momento, para muitas comunidades, as medidas de apoio e resgate ocorreram dentro da própria vizinhança a partir de iniciativas dos cidadãos/moradores do bairro ou entorno que, preocupados com o bem-estar dos demais, tomaram a frente da situação e deram início aos procedimentos de primeiros socorros com objetivo de salvar pessoas ou tentaram recuperar objetos pessoais e bens materiais, além de facilitarem o acesso aos profissionais que chegavam aos locais atingidos. Estas ações solidárias foram reconhecidas como destemidas e heroicas, o que ficou evidente na fala de nossos entrevistados.

Todo mundo que podia ajudar estava lá, fazendo sua parte... os mais fortes e novinhos foram os que mais ajudaram a pegar coisa das casas, eletrodoméstico, essas coisas assim mais pesadas... mas também tinha muita gente preocupada em salvar os animais, ajudar as crianças, as pessoas de mais idade... quem pôde ajudar, ajudou, quem sabia e podia ajudar tava ali firme e forte mesmo com tudo de ruim que tava acontecendo em volta e isso foi o mais emocionante de ver porque, naquela situação, à noite, chovendo, ventando, sem luz, era só por amor ao próximo, de verdade! (Luzia, 32 anos)

Não dá pra explicar as coisas que a gente viu naqueles dias... tanta gente ajudando, gente se enfiando em bueiro sujo, entrando embaixo de entulho, subindo ladeira lamacenta, uma coisa que a gente acha que só acontece em filme daqueles de aventura, mas você vê ali, na sua frente, um monte de gente que não tava com medo de morrer, tava querendo ajudar sem pensar que podia se machucar, só pra fazer o bem...eu fico até emocionado em pensar que muita coisa ali só pôde ser salva por causa dessas pessoas que meteram a cara e fizeram a sua parte, enquanto a gente ainda estava esperando o resgate... não é coisa fáil de se fazer porque tem um risco de morrer ali, mas nem parecia que as pessoas pensaram nisso, e por isso muita gente se salvou, graças a esses que ajudaram... (Gerson, 49 anos) 
Foi tudo muito rápido, mas de pronto um monte de gente foi ajudar como podia... não é aquela ajuda do profissional, mas salva muita gente e isso a gente não pode deixar de falar, né? Eu sabia que tinha pessoas ali que não sabia nem ler nem escrever direito, mas que estavam pegando pedaço de pau pra levantar parede caída, se enfiando nos buracos pra ouvir se tinha alguém debaixo da terra, com lama até a cintura pra ajudar a tirar pessoas de dentro das casas que caíram... nem sempre a gente tem estudo, mas tem boa vontade, humildade, quer fazer e isso é que aquele dia a gente viu lá de sobra! Uma mão ajuda a outra e nessa hora qualquer ajuda é uma coisa bonita que não se vê todo dia... quem dera todo mundo pudesse saber de quanta gente ajudou os amigos aquele dia. (Hortência, 37 anos)

Eu nem sei te explicar o que acontece, mas a verdade é que cada um reage de um jeito e lá todo mundo tava querendo ajudar o outro mesmo quando não sabia o que fazer... isso pode ser uma coisa ruim porque a gente não sabendo ajudar pode atrapalhar, mas a intenção era fazer o bem... essa tragédia levou muita gente de muita família, e você só quer evitar de mais gente morrendo ou se machucando, e vai lá e oferece o que tem... eu queria ter ido, mas achei melhor não arriscar atrapalhar o trabalho dos outros, mas ofereci minha casa pros parentes e arrecadei dinheiro e mantimento pras famílias que perderam tudo, foi o que eu pude fazer... (Ariane, 37 anos)

Mesmo sabendo que estes comportamentos poderiam colocar em risco a vida dos que ajudavam, todos os participantes compreenderam que, em um momento como aquele, é impossível não se solidarizar com o sofrimento alheio e, na ausência dos profissionais especializados, os moradores/vítimas/sobreviventes tiveram que tomar atitudes "impensadas" do ponto de vista lógico, mas completamente compreensíveis sob o ponto de vista humano:

Eu vi cada coisa que contando não dá em pra acreditar! Teve um menino que devia ter uns 17 anos que entrou de cabeça numa boca-de-lobo pra tirar um cachorro que a água tava levando... uma senhora pegou os dois filhos no colo e conseguiu subir numa ripa de madeira bem fina até que um moço ajudou a tirar as crianças dali... e o pessoal que tava tirando colchão, geladeira, fogão, essas coisas, descendo ladeira abaixo com lama até nos cabelos de tão ruim que tava lá? Pensa no perigo que esses meninos correram pra salvar o que a gente luta tanto pra conseguir, não é? É aquele sentimento de que a gente precisa ajudar, de um jeito ou de outro, pra sobreviver o máximo de gente naquele mundo de tragédia... (Osmar, 51 anos)

Não é que eu acho que as pessoas não sabiam que elas podia se machucar, mas eu entendo que naquela hora você deixa isso pra lá e corre pra acudir quem é mais fraco ou que tá precisando de ajuda... não pode se colocar um ponto e sair correndo sozinho, a gente não consegue! Voltar pra ajudar era a única coisa que as pessoas tinham certeza que era certo fazer aquele dia. A gente não pode 
simplesmente ficar de telespectador quando tudo que está acontecendo está ali, embaixo do seu próprio nariz! Quem viveu aquilo tudo sabe que não é o mais inteligente mas é o mais correto com os outros que estão em dificuldade! Não tem medo que pare uma pessoa que queira ajudar, nem medo de morrer! (Bárbara, 25 anos)

Por mais que a gente saiba que tem perigo, tem pessoas ali morrendo, machucadas, com criança de colo, idosos, tem muita gente precisando de ajuda de verdade e que, na correria, não dá pra deixar de voltar, entende? O mais difícil é ver que nem todo mundo conseguiu ser ajudado, mas das coisas que as pessoas podiam fazer elas fizeram, e como! Teve gente se amarrando em árvore pra pegar gente que a correnteza tava puxando, pessoal em cima dos carros pra poder levantar criança pequena que não podia andar sozinha, e mais aquelas pessoas que se penduravam nos postes e nas placas pra pegar o que os outros passavam das casas antes delas caírem... tudo de solidariedade que você possa imaginar aconteceu ali naqueles dias, sem nem pensar duas vezes! (Olímpia, 43 anos)

Muitos moradores, mesmo após a chegada da Defesa Civil e do Corpo de Bombeiros, permaneceram no local dos desabamentos para continuar apoiando nas buscas por pessoas feridas ou mortas, além de auxiliar idosos, crianças e famílias a alcançarem locais seguros. Muitos moradores relatam que os bombeiros pediam que os voluntários se afastassem, pois ali corriam risco de sofrerem lesões ou mesmo de novos soterramentos, mas estes não cediam e mantinham-se alertas para apoiar no que fosse possível.

Para os que acompanhavam as buscas de uma distância segura, foi a participação dos voluntários que agilizou grande parte das ações naquela madrugada; muitos estavam em busca de pessoas desaparecidas de sua própria família ou de alguém próximo, o que segundo os entrevistados, aumentava o fator motivacional deste apoio prestado aos bombeiros. Mas, apesar de não abandonarem os locais afetados, vale ressaltar o cuidado que todos os voluntários tiveram em atender as recomendações da Defesa Civil em relação a não mover os corpos localizados: os voluntários continuaram apoiando nas buscas, mas não faziam nada que pudesse comprometer a integridade física de quem fosse encontrado sob os escombros, deixando a parte de remoção propriamente dita para os profissionais especializados no assunto. $\mathrm{O}$ intuito dos voluntários era ser útil e agilizar os procedimentos de resgate, desde que sua ação não comprometesse em absoluto o trabalho realizado pelos profissionais treinados. 
Eu vi muita gente ajudando, segurando pedaço de madeira pros bombeiros, tirando folha de bueiro, tudo que podia fazer, mas se encontrasse alguém machucado ou mesmo ali, morto, ninguém mexia antes do bombeiro porque a gente não sabe como tirar as pessoas nessas situações... vai que a gente piora a condição de quem tá machucado ou então quebra alguma coisa? Então todo mundo quer ajudar mas sabe que não tem o conhecimento pra um monte de coisas e ficava mais ali, olhando, esperando alguma orientação dos bombeiros... muita gente ficou ali de apoio pro que pudesse fazer pra ajudar. Eu acho isso o certo, $e$ naquele dia tava todo mundo bem atento pra não causar um mal maior do que o que a chuva já tinha feito pra todo mundo (Ariane, 37 anos).

Pode dizer o que quiser daquele dia, mas a gente nunca atrapalhou os bombeiros e o pessoal da Defesa Civil! Foi todo mundo ouvindo as orientações e não mexia nas pessoas que a gente ia encontrando porque se você errar ali pode custar a vida de alguém! Ninguém tem o conhecimento que os caras têm, então não pode brincar com coisa séria. Eu sei que a vontade de ajudar era grande, mas ninguém ali tem mais capacidade que os caras que trabalham com isso todo dia! A gente ajudou a carregar muita maca, a esticar as cordas de isolamento, até tirar as coisas das casas a gente tava ali, mas quem podia mexer nas pessoas que a gente encontrava eram os caras profissionais mesmo, e a gente entende que esse é o certo a se fazer numa hora dessas porque você tá ali pra ajudar e não pra atrapalhar! (Emerson, 37 anos)

Na hora todo mundo quer ajudar e tirar todo mundo de lá daquela lama toda, mas nem sempre a gente tem as coisas, né? Tem aqueles negócios pra segurar o pescoço, as macas, essas coisas que ajudam a deixar a pessoa retinha pra não machucar mais... lá tinha muita gente querendo pegar no colo, levar pra um lugar mais seco e tratar dos machucados, mas o que a gente ouvia dos bombeiros era pra deixar ali que eles iam trabalhar com as pessoas machucadas e foi isso que a gente fez, pra não correr o risco de machucar mais ninguém ali... eu trabalho com faxina e não vou deixar alguém fazer meu trabalho sem ensinar, então eu também não vou fazer o do bombeiro pra depois ele ter eu fazer tudo de novo porque eu fiz errado, né? (Hortência, 37 anos)

Assim que os bombeiros e funcionários da Defesa Civil chegaram aos locais atingidos para realizar o resgate de feridos e demarcar as interdições nas construções em áreas de risco, muitos voluntários tiveram que abandonar suas moradias e seguir para os abrigos ou casa de familiares, mas o desejo de ajudar se manteve aceso. Após a primeira semana de chuvas ocorridas na região, muitos sobreviventes e moradores da região concentraram seus esforços na aquisição de alimentos, água potável, ferramentas e utensílios para ajudar na limpeza dos locais, pois este trabalho era não só necessário, mas lhes dava a sensação de estarem sendo úteis para a comunidade. 
Entre os homens foram frequentes as ações nos locais atingidos, transporte de pessoas e materiais e busca por suprimentos e mantimentos (descarga de caminhões, por exemplo). Já entre as mulheres, muitas se revezaram no cuidado das crianças nos abrigos, assim como se voluntariavam para fazer as refeições para os que estivessem trabalhando incansavelmente nos terrenos em busca de sobreviventes, corpos e bens dos desabrigados:

Nem sempre a gente tinha abundância de comida e água, mas o que tem a gente repartia pra todo mundo. Os abrigos estavam lotados e ninguém tinha previsão de poder ir pra casa ou pra outro lugar seguro naquelas semanas. O que a gente fazia era deixar o lugar mais confortável pra os idosos e pras crianças, $e$ assim os pais podia tentar resolver outras coisas... o mais difícil nessas horas é começar, mas depois você passa a ter uma rotina lá, fazendo comida, separando roupa doada, ajudando as crianças com coisas pequenas, tudo que dê pra tirar um pouco o sofrimento de quem tá ali, sem nada e isso faz a gente tirar forças não sei de onde pra continuar dia após dia... mas não é fácil... (Bárbara, 25 anos)

Eu fiz muita comida, sopa, separava roupa de doação, pegava brinquedo pras crianças, ajudava a dar banho nas pessoas mais velhas, arrumava tempo pra ir lá no morro pra conversar com os bombeiros, levava comida pra eles também, $e$ assim a gente foi vivendo aqueles dias... foi muito bom ver que Deus me permitiu ter forças pra enfrentar essas dificuldades, mas se você não ajuda o próximo, nada disso faz sentido! Você vê só os bombeiros: que lida! A gente tem que bater palmas pra eles e eu ia, agradecia, levava água, cafezinho, biscoito, tudo pra eles ficarem bem ali pra fazer o trabalho deles porque não é fácil... e eu fazendo minha parte, eles a deles e assim todo mundo se ajudou muito aqueles dias porque a gente não vive sozinho nesse mundo, não é? (Zenaide, 44 anos).

Parece mentira, mas naqueles dias eu realmente percebi o quanto um bombeiro trabalha e como a gente pode ser útil pra alguém! Não é que eu não achasse o bombeiro uma profissão bonita, mas só nessas horas a gente entende o quanto eles trabalham pra ajudar as pessoas que passam por essa tragédia! Eu não sou de reclamar, então corri atrás e fui ajudar também porque é assim que a gente deve se comportar nessas horas: recebe ajuda, dá ajuda! Não é tão difícil fazer as coisas, mesmo quando você tem suas preocupações, porque você perdeu mas os outros também perderam e nessa hora você não pode olhar só seu umbigo; aí foram vários dias que a gente cozinhou, lavou, passou roupa, brincou com as crianças, subiu e desceu de caminhão com donativo e os bombeiros lá, trabalhando... se cada um fizesse sempre sua parte, a gente ia ter mais coisa pra ganhar do que pra perder, sabe? (Tereza, 44 anos).

Estes dados corroboram com os achados de Oliveira (2008) que constatou que o grupo de iguais fornece ao enlutado apoio e continência, o que facilita a elaboração da perda, pois ao sentir-se semelhante a pessoas que vivenciaram os 
mesmos lutos, é possível expressar-se, ser compreendida e ter seu sofrimento validado pelo outro e, consequentemente, por si mesmo. Sentir-se útil e ativo em coletividade também ajuda os enlutados a seguir com a busca pelos entes queridos ao mesmo tempo em que dão um novo rumo a vida, tornando esse processo de enfrentamento mais dinâmico.

Outra particularidade do desastre na Região Serrana foi o apelo da mídia para que a população prestasse seu apoio através de doações para os desabrigados. Muitas campanhas tomaram conta das emissoras de televisão, redes sociais e demais veículos de divulgação, e vários postos de recolhimento de doações foram abertos em diversas regiões do Rio de Janeiro, assim como em outros estados do país. Contas bancárias foram abertas para aqueles que optassem por doar em dinheiro, e órgãos como a Marinha, a Aeronáutica e o Exército Brasileiro foram mobilizados para apoiar não só nas atividades locais, mas também para o transporte e entrega dos materiais doados.

Este movimento de solidariedade social repercutiu de duas formas diferentes aos olhos dos entrevistados: por um lado, alguns participantes reconhecem ter recebido ajuda de pessoas estranhas e que este gesto leva a um sentimento de acolhimento e gratidão:

Eu fiquei boba de ver quanta gente tava ajudando o pessoal de lá... todo dia chegava comida, roupa, água, tudo que você possa imaginar! Nessa hora a gente vê que o povo brasileiro é muito solidário, tem coração grande, quer ajudar o próximo mesmo! E a gente sabe que muita gente que ajuda nem é rica; é muita gente pobre que tira do bolso pra dar pro outro que naquela hora tá precisando mais que ele e isso é bonito de se ver... eu vi gente que não tinha uma roupa limpa pra vestir e de repente tinha roupa até melhor do que antes pra usar graças a alguém que tava ali, preocupado com a nossa região (Olímpia, 43 anos)

Todo mundo viu a quantidade de coisas que chegavam lá nas comunidades todo dia, quanta roupa, comida, água, leite, sacos de lixo, material de higiene, essas coisas que a gente não tinha nem como comprar porque até as farmácias e lojas tinham caído por causa da chuva... eu tive que admitir que o brasileiro é mesmo um povo solidário, que ajuda os outros na hora da necessidade, que tem fé que as coisas vão melhorar e sem nada em troca, só pelo querer ajudar mesmo! Eu fiquei emocionada vendo que tinha gente ajudando até com bichinho de pelúcia, boneca e carrinho pras crianças porque pra elas também era difícil ficar ali, sem nada pra fazer, sem escola, sem parquinho, sem casa, sem nada... eu chorei muito no dia que eu vi chegando um rapaz com um caminhão cheio de bolas coloridas e brinquedos, e depois tinha roupa nova pra molecada também... solidariedade é isso, você dá uma coisa que alguém não tem em troca de um sorriso! (Verônica, 28 anos) 
Muito bonito mesmo ver quanta gente tava mandando coisas pro pessoal desabrigado, daquelas coisas que a gente não tinha mais nem de onde tirar... todo dia chegava doação, toda hora tinha alguém falando que ia chegar mais água, mais comida, roupa limpa, fralda pros bebês, essas coisinhas... é aquela coisa: cada um ajuda como pode e a gente recebeu muita ajuda de gente que nem era daqui do país, imagina só! Não é uma coisa de Deus? Imagina de um dia pro outro você não ter uma peça de roupa pra usar, nem um pedaço de sabão pra tomar banho... imagina sem nem água limpa pra beber? Se não fosse as doações a gente tava era lascado de tudo! Eu fiquei muito agradecido com essas coisas, acho que a gente quer mais receber do que dar e nessas horas você descobre que tem um monte de gente no mundo que quer mais dar do que receber! (Gerson, 49 anos)

Nunca vi nada igual, as pessoas todas trabalhando de sol a sol pra poder tirar aquele monte de sujeira, entulho, tudo no caminho, e depois de um tempo aquilo não é mais notícia, as coisas continuam acontecendo no mundo e você que tá ali, procurando saber como vai ajeitar sua vida, fica esperando uma resposta da Prefeitura ou de quem quer que seja e não chega nada... tudo que tinha era de doação, da boa vontade das pessoas, e daí o pessoal foi se organizando pra limpar e reerguer as coisas, mas é difícil mexer com essas coisas porque tudo é caro e o povo não tinha dinheiro nem pra comer... triste essa realidade da gente! (Hortência, 37 anos)

Por outro lado, para alguns entrevistados, ficou evidente a falta de proteção por parte do Estado e a impressão de que quem doa quer parecer solidário quando não é pois, em geral, os donativos vêm de pessoas muito abastadas que ficam penalizadas com a situação dos desalojados, dando a eles os "restos" daquilo que não querem mais. Para alguns entrevistados, o sentimento foi de incômodo com a ideia de que outras pessoas possam sentir dó e compaixão por algo que deveria ter sido prevenido pelos governantes das cidades atingidas:

É uma pouca vergonha a gente ter prefeito e subprefeito pra dar as coisas que a gente precisa e quando acontece uma coisa dessa eu ficar recebendo doação de atorzinho da Globo ou pessoal daquelas empresas grandes que tem de tudo! Imagina que não teve nenhum apoio do pessoal aqui da região que a gente conhecia, nem mesmo os que a gente vota na eleição, mas caminhão do Faustão e até o dono daquela loja de coisa pra casa deu um monte de coisa pro pessoal aqui... é uma vergonha ter que ficar recebendo essas coisas quando a gente paga nossos impostos e trabalha tanto... eu aprendi com meus pais que tudo que vem de mão beijada é ruim, não serve, e aí ganhar tudo novo de alguém que eu não conheço é até errado! (Cândido, 53 anos)

Eu não sei se as pessoas ajudam porque não sabem o que fazer com tanto dinheiro ou se acham a gente tão pobre que não tem como sobreviver, só sei que as pessoas ficam cheias de pena quando acontece essas coisas e não é um sentimento bom pra ninguém... fica aparecendo na TV que tem um monte de coitadinho e não é bem assim! Aqui todo mundo é trabalhador, mãe e pai de 
família, dá de comer pros filhos, é gente que trabalha e ganha seu sustento que nem todo mundo, mas que por causa desse descaso, todo ano acontece tudo igual! Eu não gosto de pegar nada que ninguém manda nessas campanhas porque fica parecendo que a gente é tudo morto de fome que fica sugando o dinheiro dos outros... e o governo, que tem que proteger a população, cadê? Cadê o pessoal da assistência social pra dar um apoio às famílias? Nessa hora só aparece gente que não tem nada a ver com a gente pra dar as coisas, mas depois de um mês, dois meses some todo mundo de novo e a gente fica aqui, sem nada! (Monica, 42 anos).

Pra ficar ganhando coisa que os outros não querem mais, eu não quero! Acho uma pouca vergonha isso da gente ficar ganhando esmola quando a gente precisa mesmo é de um lugar bom pra morar, de segurança na comunidade, de coisa que os políticos só promete em época de eleição e depois some tudo aí pra dentro das salas deles! As pessoas vêm aqui, choram junto com a gente, mas depois voltam lá pro Leblon, pegar sua praia, ficar na varanda e nem lembram mais que a gente vai ficar sem casa... nada da gente ter nossa vida de novo, os políticos enchendo o bolso de dinheiro e quem tá aqui fica num esquecimento só... quem tem pena é galinha, a gente quer é respeito! (Suely, 39 anos).

Além disso, podemos destacar a incredulidade dos sobreviventes em ações governamentais que pudessem, efetivamente, beneficiar a população, que percebe as investidas políticas como formas de manipular a população em busca de votos, mas sem resolver de forma eficaz os problemas que, anualmente, atingem os moradores da Região Serrana.

Tem um monte de político que some na hora da tragédia e outros aparecem pra dizer que vão ajudar a reconstruir a cidade mas depois somem também... é aquela mesma papagaiada de sempre, com um monte de promessa e todo ano acontece a tragédia de novo e ninguém resolve nada... claro que tem gente que aceita ajuda porque tá na necessidade, precisando até de comida, mas em troca de voto? Eu não acredito mais em político nenhum, pra mim eles são tudo uns mentirosos e interesseiros e querem mais é que a cidade caia toda pra eles poderem ter mais coisa pra prometer e não cumprir... a gente sofrendo tudo aqui nessa vida e eles ainda ficam vindo pegar criança no colo e dar cesta básica pra meia dúzia de pessoas... melhorar a situação do pessoal das enchentes ninguém melhora! (Ronaldo, 35 anos)

Quem ainda acredita em algum político? Tem gente aqui da região que foi eleita que nem na época das chuvas apareceu, e tem uns que a gente nunca viu na vida e se fazem de amigos da comunidade, dizem ter a solução dos problemas, que vão melhorar tudo no ano que vem... só mentira, né? Ninguém quer ajudar o pobre favelado a sair dessa condição, acham que a gente que tá aqui ilegal e preferem que as casas caiam mesmo! Vai dizer que é mentira? Sempre que tem chuva aparece um monte de homem falso e arrogante aqui em pele de cordeiro, querendo ajudar de mentira, falando coisa que os outros querem escutar mas que depois evapora, um absurdo isso que a gente vê! (Mônica, 42 anos) 
Todo mundo sabe que tragédia atrai político, né? Eu fico pasma de ver a quantidade de político que aparece prometendo mundos e fundos pros desabrigados e depois nada feito! O prefeito veio pra dar os pêsames pras famílias e quase foi linchado de tanto ódio das pessoas porque é um abandono, não é? A gente passa todo tempo trabalhando pra chegar no começo do ano e perder tudo na enchente e eles passam um ano fazendo horário político e 4 anos sem fazer nada... é pra ficar muito irritado mesmo! Eu não acredito quando eles vêm falar que vão fazer e acontecer porque ninguém que fica só falando faz alguma coisa... tem gente que ainda acredita, mas é gente mais velha, tem coração bom... a gente que não vê resultado sabe que não vai mudar nada... (Zenaide, 44 anos)

Alguns moradores admitem que, por morarem em locais considerados como zonas de risco, podem estar mais expostos a intempéries e novas ocorrências de desastres como os de 2011, e sabem que suas casas foram, em grande parte, construídas sobre terrenos com maior probabilidade de erosão e desgaste quando em contato com as chuvas, mas a falta de condições econômicas impede que eles deixem as condições atuais de moradia.

Se a gente tivesse condição de morar num bairro bom, mais embaixo, no asfalto mesmo, a gente não estaria passando todo ano esse aperto aqui... mas é o que dá pra gente pagar nessa vida! Eu não quero ficar minha vida toda subindo e descendo morro com geladeira nas costas porque todo verão chove e tudo cai, mas pra onde eu vou, meu Deus? Quem sabe se o Governo ajudasse mais a população a gente teria melhoria nos lugares que a gente mora, mas por agora é o que tem pra gente viver e não dá pra mudar de uma hora pra outra... triste é que é sempre a mesma coisa... até quando isso? (Hortência, 37 anos).

Eu sei que não é o melhor lugar pra gente morar, que tem muito barranco e tudo pode cair de repente, mas como que eu posso levar minha família daqui se não tem um lugar pra gente ir? Não é que a gente não saiba do risco de morar no morro, mas tem coisas que a gente não tem como mudar! Eu queria muito que a vida da gente fosse diferente, que a gente pudesse ganhar mais um pouquinho pra melhorar de vida, mas daí a gente poder mesmo é outros quinhentos! É um sofrimento, todo ano chove, a gente perde coisa, dessa vez perdemos até família, mas pra mudar isso tem que ter condição e hoje eu não tenho... (Sérgio, 49 anos).

Não acredito que as pessoas não entendam que é um perigo morar na encosta, eu sei disso... a gente ouve o barulho da chuva e já treme de medo... aqui tudo é muito caro e se você quer continuar morando na cidade é assim, onde dá pra sustentar sua família sem ter que cair pra criminalidade, entende? Não é só uma coisa de dinheiro, mas de ter opção de lugar pra ir que não seja um assalto de aluguel! Eu não sou rico, nunca fui... não tive muito ensino, mas trabalho e corro atrás do meu sustento, mas quem pode pagar essas coisas todas hoje em dia sem dificuldade? Pouca gente! Aí o que acontece é ficar nessa situação, sempre correndo o risco de perder o pouquinho que se tem pra água e pra lama... (Cândido, 53 anos) 
Esta culpa que muitos carregam sobre si tem origem também em um discurso institucionalizado de que residir nestas localidades é uma escolha arriscada mas consciente dos moradores das encostas. No entanto, devemos olhar esta questão de um ponto de vista sociopolítico e histórico, pelo qual a desigualdade social e a falta de oportunidades também se faz presente na história da construção e urbanização das cidades, deixando marginalizados os membros da sociedade que não se adéquam ao grupo mais elitizado da sociedade - e, sob essa ótica, merecem as mazelas que enfrenta todos os dias (VALENCIO, 2004).

Para os que ainda estão morando em casas de familiares ou abrigos, o descaso das Prefeituras é evidente, o que aumenta o sentimento de desamparo e insegurança em relação ao futuro. Todos testemunharam discursos de governantes sobre valores a serem investidos na reconstrução das cidades e sentiram-se esperançosos para recomeçar a vida em comunidade, mas com o passar do tempo, poucos foram os projetos de casas concluídos o que, segundo eles, evidencia o desvio do dinheiro arrecadado para as novas moradias populares:

O pessoal se mexe porque se não fizer o Governo não mexe uma palha pra fazer nada! Prometeram, prometeram, mas nada de enviar as coisas pros desabrigados... quer ver uma coisa: como é que eles querem achar os corpos dos que sumiram, como? Depois de um tempo a Defesa Civil simplesmente foi embora porque se não tem dinheiro não tem como procurar. Aí aparece político falando que vai fazer, mas quem faz mesmo é a população que primeiro perde e depois fica lá, jogada ao azar...eu entendo que eles tenham dificuldade pra consertar tudo de uma vez só, mas não é dinheiro que tá faltando, vai! (Sérgio, 49 anos)

É claro que a gente sabe que teve desvio de dinheiro pra reconstruir os bairros, né? Imagina você vendo esse tempo todo o pessoal da TV falando que a presidenta mandou dinheiro, que o prefeito já recebeu e aqui, a gente que tá nessa situação, não vendo nada mudar, nada melhorar, vai acreditar em que? Todo mundo falou que a gente ia receber moradia nova, que ia ter casa boa e segura pras famílias que foram pros abrigos, mas nada mudou! A gente tenta acreditar que as coisas vão melhorar mas se quem tem que cuidar da gente é quem tá roubando, como é que faz? Uma vergonha passar por isso, é uma humilhação viver nessas condições e ainda ouvir que vai mudar! (Mônica, 42 anos).

A minha maior decepção nessa vida é que a gente sabe que os políticos que a gente votou estão tudo roubando a gente. Eu fico de cabelo em pé de ver que tinha um montão de dinheiro que ia ajudar o pessoal e nada desse dinheiro chegar na cidades, e as pessoas passando necessidade e ninguém faz nada... é um bando de safados, tudo ladrão, e nós nessa vida, comendo comida que os outros manda, fazendo de tudo pra criar as crianças na dignidade mas não tem bom exemplo que 
ajude nisso... eu sei que a gente tem que ajeitar tudo com calma pras coisas não acontecerem de novo do jeito que foi, mas ficar vivendo desse jeito não é bom pra ninguém, ainda mais porque tem dinheiro pra ajudar o povo (Suely, 39 anos).

Só quem viveu isso tudo sabe das dificuldades que a gente tá passando por causa da falta de vergonha do pessoal que devia estar ajudando a gente... esse tempo todo a gente morando no abrigo e não vem uma pessoa falar nada com a gente, não dá uma solução pra nossa vida e nem parece que vai dar uma resposta pra gente tão cedo... muito triste passar por isso, não ter a vida em família como antes, ficar nesse miserê sem dó nem piedade enquanto tem alguém engordando o bolso com o dinheiro da chuva... você tem certeza que não dá pra confiar na palavra de ninguém! É isso que tá acontecendo aqui na região; nem pra dar uma posição pra nós, nem pra dar uma esperança de que vai ajudar o pessoal daqui, ninguém fala nada... a gente tá esquecido aqui, como se tivesse morrido com os outros (Tereza, 42 anos).

Mesmo os que não perderam suas casas sentem também a insegurança diante da falta de investimento em medidas eficazes de prevenção diante de novas intempéries, tendo em vista que a região é comumente atingida, com frequência, por fortes chuvas entre os meses de janeiro a março. Segundo os participantes, suas famílias estão constantemente expostas ao risco de novos desastres e, consequentemente, a novas perdas.

Todo começo de ano eu fico numa agonia, com aquele medo de que dessa vez a minha casa também vai cair? Dá aquele frio na barriga, um medo muito grande de estar em casa com os filhos e de repente tudo começar a desmoronar? A gente ficou muito impressionada com tanta destruição, com a quantidade de gente que perdeu tudo, de gente que morreu, com a força da água... eu não sei se tiver outra chuva dessa se onde a gente mora vai ter segurança suficiente pra segurar... falam que a terra fica molhada, a casa vai ficando com a estrutura abalada, aî vem mais uma chuva dessas e acaba com tudo que a gente tem... só pedindo a Deus pra que isso não aconteça porque se depender da Prefeitura morre um tanto de gente de novo (Zenaide, 44 anos).

Dessa vez a gente teve muita sorte de não ter acontecido nada com a nossa casa, mas quem garante que no ano que vem ou no outro a gente vai conseguir? Ninguém tá seguro, a vida é assim... tem horas que a gente pensa mais nisso, né? Eu falei com uma amiga que perdeu tudo que ela tinha que pensar que todo mundo pode passar por isso morando aqui na serra porque todo ano acontece a mesma coisa e pode ser hoje a dela, mas amanhã pode ser a minha, e isso deixa a gente preocupado. Não tem investimento de governo, vai continuar chovendo e a gente quer continuar morando aqui, então tem que ter fé. Não tem ninguém seguro nessa região aqui porque todo ano a gente vê que a chuva vem e as pessoas passam por tudo isso de novo... Tudo pode acontecer com qualquer pessoa em qualquer momento da vida da gente, basta estar vivo e morar nesses lugares que a gente começa a ver que é isso aí que a gente tem pra viver! (Ronaldo, 35 anos) 
Pra ter certeza de que nunca vai acontecer, tem que ter mais segurança pra população, sabe? Mais recurso pra segurar os barrancos, tem que ter pessoal trabalhando sempre na limpeza da cidade, pra não acumular água nas ruas, tem que trabalhar com o pessoal dos morros pra cuidar das casas que tem mais risco, essas coisas. Se não fizer nada disso, pode cair tudo de novo, e eu não tô livre disso, nem minha família, nem as pessoas que já perderam tudo nessa chuva porque enquanto não mudar essas coisas que eu falei, tem muito perigo disso acontecer de novo. Fica fácil falar que vai mudar, difícil mesmo é não deixar isso acontecer com um povo que já sofre tanto o ano todo na batalha diária... pra acreditar a gente tem que ver mudança, senão não pode ter certeza (Olímpia, 43 anos).

Este sentimento de desamparo e insegurança claramente interfere no processo de enfrentamento das perdas vividas após o desastre, e os sobreviventes constantemente se veem revivendo os eventos de janeiro de 2011, já que novas precauções não são adotadas e futuras catástrofes iguais ou até mesmo piores podem se abater sobre as comunidades ainda tão fragilizadas. A não reconstrução dos espaços públicos, a falta de investimento na construção de novas casas populares e o descompromisso com os que ainda estão alojados nos abrigos da Prefeitura só aumenta sentimentos como raiva, inquietação, tristeza, incredulidade, conformismo e desesperança.

Diante da total falta de investimento público na reconstrução das comunidades atingidas, assim como em medidas preventivas que se proponham a evitar a recorrência de um grande número de perdas humanas, materiais e sociais como as vividas em 2011, a população sobrevivente adotou medidas de apoio mútuo desde os dias seguintes ao desastre, formando um grupo coeso e preocupado em amenizar os efeitos desta tragédia que se abateu sobre tantas famílias, prática muito comum em casos de desastre massivo.

Dentre esses, foram formados diversos os grupos para manter ativas as buscas por pessoas desaparecidas na região. O grupo se dividia entre os que iam às Delegacias e postos de atendimento da Cruz Vermelha para cobrar respostas, divulgar fotos e fornecer novas informações que pudessem auxiliar nas buscas aos ausentes; enquanto outra parte do grupo dirigia-se aos locais onde as pessoas desaparecidas poderiam ter estado pela última vez, para de perto poderem acompanhar, junto à Defesa Civil e aos Bombeiros, o trabalho das escavações e remoção dos escombros. 
Tinha um monte de gente que se encontrava todo dia na frente do abrigo pra sair pra procurar pelo pessoal que tava sumido, e fazia de tudo pra conseguir encontrar as pessoas, $e$ isso foi muito bonito das pessoas. Eu mesmo fui ajudar a procurar o pessoal lá nos vilarejos mais afastados porque a gente sabia que podia ter gente fugida lá, pessoal que foi procurar abrigo da chuva e ficou isolado nesses cantões. Não sei se a gente ajudou na busca, mas a gente se ajudou muito, torceu muito um pelo outro e foi atrás, porque se dependesse do governo não ia ter muita procura. É o que dizem, a união faz a força mesmo, é assim que funcionou lá e que fez a gente segurar a onda nos dias de mais dificuldade (Gerson, 49 anos).

O pessoal bairro tava muito unido, buscando os desaparecidos até em dia que a chuva apertava mais... os bombeiros tavam trabalhando muito, eu vi, mas quem tava procurando informação foi todo dia atrás de alguma novidade, de saber se tinham encontrado mais alguém. Eu acho que na hora do sofrimento é mais importante conhecer gente que pode te ajudar, que tá querendo seu bem mesmo sem nem te conhecer, e isso foi o que a gente viveu naquelas semanas. Cada dia que passava, demorava mais pra conseguir achar as pessoas, mas ali, naquela confusão, muita amizade verdadeira apareceu e continua até hoje, pra você ver como é importante saber com quem a gente pode contar... (Verônica, 28 anos).

Eu ia sempre que podia acompanhar o pessoal lá dos Bombeiros porque a gente fica numa ansiedade, contando as horas pra saber se nosso familiar foi encontrado ou não... ainda bem que tinha um monte de gente da comunidade lá junto comigo porque aí a gente ia junto e ficava mais fácil esperar pelas notícias do dia, sabe? Eu fico muito agoniada com essas coisas porque na hora da raiva, a gente as vezes pode tratar uma pessoa com desrespeito e tudo, mas aí quando você tá com os colegas, dá pra dividir essas coisas e o peito fica menos apertado... já era tão difícil ficar ali, do lado do terreno, esperando saber se eles tinham achado mais alguém, mas quando você olha pro lado e vê que ali tem alguém que também tá naquela expectativa, fica mais leve o dia... (Flávia, 33 anos)

Outra forma de coesão grupal ocorreu após a liberação dos terrenos já fiscalizados pela Defesa Civil. Após cerca de quatro meses das chuvas na região, as máquinas da Prefeitura (escavadeiras, recolhedoras, guinchos, máquinas coletoras de lixo) já haviam aplainado alguns desbarrancamentos antes cobertos de lama, escombros e sujeira, e estes locais tornaram-se progressivamente mais aptos para receber novamente construções de casas e unidades de comércio; porém, diante da morosidade das prefeituras, os próprios moradores resolveram investir na reconstrução dos locais de referência como Igrejas, estabelecimentos de ensino provisórios, lojas comerciais (especialmente de alimentos) e algumas casas populares. 
A gente resolveu colocar a mão na massa ali mesmo porque ninguém queria fazer pela gente, não é mesmo? Ficamos ali, só esperando, esperando e nada, e se não querem ajudar, a gente vai lá e faz! Eu sei que não é o certo porque eles que deviam construir tudo de novo, mas se a gente ficar só ali, de braços cruzados, é capaz de ficar na rua com os filhos até morrer! A gente ergueu muro, subiu escolinha, pintou casa, fez mercadinho improvisado, pra todo mundo começar a fazer a vida começar de novo, né? Eu mesmo não sou novo, mas fui lá e dei minha contribuição, porque a gente tá mais velho mas ainda tem muito pra viver, mesmo que o pessoal que devia estar ajudando não ajude...cada um sabe de si e tem que pensar no pessoal lá do bairro também que perdeu muita coisa... (Sérgio, 49 anos)

Eu fiquei muito comovida com as pessoas porque eu perdi tudo, minha filha, e foram os meus vizinhos que me ajudaram a arrumar a minha vida e dos meus filhos... eu não tenho a minha casinha de volta ainda, mas eu sei que muita gente só conseguiu voltar a morar lá na comunidade porque os rapazes da vizinhança passaram a mão na pá e na cal e vamos subir as casas! Até e igrejinha da esquina os meninos ajudaram a levantar, só pro padre poder dar a benção enquanto eles trabalhavam. A gente sente a felicidade do pessoal vendo as coisas voltando a ser do jeitinho de antes, pena que tinha que acontecer tudo isso pra gente se juntar de verdade... (Luzia, 32 anos)

Teve muita gente que desistiu de ficar esperando o tal dinheiro das casas que anunciava na televisão e voltou pra comunidade pra poder levantar as coisas por lá. A gente perdeu tudo que tinha: farmácia, escola, padaria, casa, igreja, tudo! Aí você pensa assim: se eu começar montando uma farmácia, o pessoal que se machucou ou os velhinhos que estão doentes podem ficar melhor.. aí foram lá e improvisaram uma farmacinha... depois pensaram numa venda de coisas de higiene e de comer pra gente poder comprar uma coisinha ou outra, principalmente pras crianças que não entendem que não tem mais mercado nem nada pra comprar um agrado... aí depois vem as escolinhas, as igrejas, o posto de saúde da família e tudo foi aparecendo de novo, de pouquinho em pouquinho, mas isso com esforço da gente mesmo, porque se dependesse da Prefeitura, a gente ficava ali, pelado e sem rumo... (Suely, 39 anos)

Como podemos notar, o sentido da reconstrução nasceu dentro da própria comunidade que, não atendida pelo poder público, adotou suas próprias medidas para recomeçar. $\mathrm{O}$ ato de reconstrução concreta das cidades parece ter aumentado a capacidade dos sobreviventes de reconstruir suas próprias histórias, como se cada parede levantada e cada nova casa ou estabelecimento erguidos representassem uma parte da comunidade se restabelecendo diante de todo o caos. A união das comunidades atingidas estabeleceu um espaço de troca e ajuda mútua, deflagrando o potencial regenerativo e resiliente do grupo (VALENCIO, 2004). 
Podemos concluir que a reconstrução individual se dá na interface com a reconstrução coletiva, e se fortalece na garra e na coragem de seus membros que, juntos, lutam por um novo começo, mesmo cientes de que pouco (ou nada) tem sido feito para evitar novas tragédias. Os relatos de nossos entrevistados apontam para essa dura realidade e fazem urgir um sentimento único: nossa História precisa mudar, para que as histórias individuais e coletivas destas e das futuras gerações possam superar estes traumas, tornando assim mais saudável e próspero o futuro de toda a nação. 


\section{CONSIDERAÇÕES FINAIS}

Ao iniciarmos esta pesquisa, tínhamos como objetivos refletir sobre os aspectos envolvidos na difícil tarefa de sobreviver a um desastre - em especial quando um membro da família desaparece na ocasião - bem como buscar uma melhor compreensão acerca deste tipo de fenômeno e descobrir quais são as estratégias possíveis adotadas por indivíduos e comunidades durante a reconstrução de suas vidas após múltiplas perdas. Aqui estamos, chegando ao fim desta jornada, completamente atravessadas por ainda mais questionamentos do que quando começamos nosso estudo.

Desastres causam perdas de vidas, de integridade física, danos materiais e econômicos, acarretando em um intenso impacto emocional nas pessoas atingidas direta e indiretamente pela catástrofe, assim como nas equipes de primeira resposta, o que pode interferir na reconstrução da comunidade afetada. Neste contexto, a Defesa Civil classifica as perdas humanas como o fator mais importantes para definir a magnitude de um desastre. Quando um evento deste porte ocorre, é imprescindível a verificação do número de mortos e feridos (graves e leves), enfermos, desaparecidos, desalojados, desabrigados e deslocados. A longo prazo, esta avaliação é refeita afim de identificar também as pessoas que sofreram danos temporários ou permanentes em decorrência do desastre (CASTRO, 2003).

Primeiramente, devemos nos perguntar: até quando vamos nomear uma catástrofe como a ocorrida na Região Serrana como um fenômeno de origem natural? É imperioso que nos impliquemos, que possamos admitir que não existem eventos exclusivamente naturais que não estejam relacionados também ao homem e ao desenvolvimento da Humanidade; somos parte desta natureza e dela recebemos o retorno por nossos próprios atos. Desastres como as chuvas no Rio de Janeiro são acontecimentos frequentes e, com o passar dos anos, cada vez mais previsíveis, o que nos faz intriga: por que a cada nova ocorrência parecemos ainda mais distantes de uma solução? Somos despreparados, omissos, desinteressados, segregadores, incompetentes ou o que? 
Obviamente não podemos transformar esta discussão em uma questão apenas sociopolítica, já que é notório e incontestável o aumento dos casos de catástrofes relacionadas a fatores geodinâmicos, pluviométricos ou tectônicos, o que nos faz perceber a cada dia a importância de adotarmos atitudes mais globais de prevenção e proteção de nossa fauna e flora e investirmos massiçamente em medidas de melhor emprego de energia e outros recursos para consumo da população. Desta forma, cada sujeito pode individualmente e, ao mesmo tempo, todos juntos, assumir a responsabilidade por um planeta mais saudável e sustentável para as próximas gerações.

Diante de relatos tão contundentes e expressivos, deparamo-nos com uma realidade muito maior do que a que inicialmente esperávamos encontrar; a vivência de um desastre é ainda mais arrebatadora do que podíamos imaginar e, em suas falas, nossos entrevistados descortinaram verdades por muitos escondidas, em especial a questão de que o sofrimento de uns pode ser usado como uma grande fonte de renda e vantagens para outros. A reconstrução das localidades devastadas mostrou-se um grande desafio diante do escancarado desvio das verbas públicas, e o abandono das comunidades atingidas deflagrou não só o descaso governamental, mas também evidencia a falta de respeito e comprometimento das autoridades com seus eleitores.

Inegavelmente as chuvas da Região Serrana foram um dos mais tristes episódios na história de nosso país, e nos assola o fato de, ainda hoje, sabermos que muitas famílias vivem em abrigos ditos "provisórios", casa de familiares ou em moradias precárias parcialmente condenadas pela Defesa Civil. Foram identificados prejuízos em todos os setores das comunidades - saúde, alimentação, agronegócio, moradias, igrejas, escolas, comércio, entre outros - o que acarretou em uma desestruturação total das cidades atingidas.

Este desastre trouxe consequências lastimáveis às cidades atingidas, ao Estado do Rio de Janeiro e também ao país, que ainda carece de medidas eficazes de prevenção a situações de emergência e de contenção de danos diante das intempéries. Esta experiência poderia ter se tornado o estopim para uma mudança de paradigma no que tange à gestão dos desastres naturais, aperfeiçoando sensivelmente a maneira de pensar da população e dos profissionais envolvidos, promovendo a produção de mais conhecimentos na área e, consequentemente, 
criando cidades mais resilientes, ou seja, que suportem melhor as adversidades naturais e diminuam as vulnerabilidades às quais a população está exposta (BRASIL, 2012).

Mas será que realmente estamos tentando mudar? Estamos mais conscientes e preparados? O ano de 2011 foi, sem dúvida, um período lastimável em relação ao número de mortos e desaparecidos nos desastres ocorridos no Brasil, especialmente na Região Serrana do Rio de Janeiro, mas o número de ações preventivas e elaboração de novas estratégias para contenção de danos em casos de desastre parece não se concretizar, e os moradores destas localidades temem os períodos de chuva a cada novo ano, como se estas fossem uma provação inevitável a uma população muitas vezes já tão carente.

Em nosso estudo pudemos constatar que, durante a fase inicial pósdesastre, os sobreviventes passam por uma forte desorganização interna e externa, mas que sentimentos de autopreservação são secundários quando há riscos para integridade física de pessoas queridas. Isto se dá especialmente com os sobreviventes diretos das catástrofes que, diante do caos e destruição, conseguem manter o foco com vistas a proteger aqueles que lhes são caros. Medo, insegurança, impotência e desamparo também se fazem presentes nesta fase, mas não superam o desejo de ajudar, contribuir e salvar.

Após o impacto inicial provocado pelo desastre, constatamos sentimentos como raiva, desespero, impotência, culpa, vergonha, desesperança e desamparo, acentuados em grande parte pela constatação gradativa das perdas humanas e materiais vividas nos dias das chuvas. Pudemos identificar que o tipo de morte, a idade do falecido e a falta de informações sobre os momentos que precederam o desaparecimento e falecimento dos entes queridos geraram ansiedade, temor, tristeza e impotência nos entrevistados, confirmando estas variáveis como fatores de risco potenciais para o desenvolvimento de um quadro de luto complicado. Entre as variáveis sociais, podemos nos referir à impossibilidade de realizar a identificação dos familiares mortos, a perda de locais de referência (como igrejas e associações comunitárias) que serviriam de alicerce para lidar com as diversas perdas vividas durante a tragédia.

A morte de familiares e amigos foi, sem dúvida, a maior fonte de tristeza e dor para os sobreviventes, e o desaparecimento de pessoas acentuou ainda mais 
estes sentimentos, especialmente por gerar ainda mais dúvidas e incertezas nas famílias já enlutadas pela tragédia. O desaparecimento de pessoas é um fenômeno complexo pois além das muitas ambiguidades comuns a este tipo de perda, pode manter por tempo indefinido uma série de sintomas relacionados ao luto, acentuados pela não confirmação da vida ou da morte daquele que permanece ausente. Em nosso estudo, o sofrimento dos sobreviventes enlutados se intensificou a partir do encerramento das buscas pelos corpos dos desaparecidos, sendo este gesto entendido como um desrespeito à memória de pessoas queridas e um descaso com o sofrimento dos que aguardavam por um fechamento. Muitos entenderam a desmobilização das equipes de busca como precoce e arbitrária, levando a sentimentos de inconformismo, raiva e indignação.

Este tópico nos remete a outra constatação importante de nossa pesquisa: pessoas carecem de rituais. Quando perdemos alguém que nos é caro, desejamos que esta perda seja reconhecida, pois neste desenlace parte de nós também se perde, e para iniciarmos nossa própria reconstrução, a etapa deve ser concluída, o que só ocorre, em muitos casos, a partir da concretização da morte no momento do rito de despedida. Para nossos participantes, a despedida de seus familiares lhes foi usurpada, já que sem os corpos tiveram que se contentar com um ato ecumênico público e coletivo com caixões vazios e presença de autoridades que não tinham nenhuma relação com as pessoas ali presentes.

Como se despedir de alguém que não foi localizado, mas que lhe obrigam a velar e enterrar? Este foi um dos muitos questionamentos citados por nossos entrevistados, que se sentiram, em parte, ofendidos e desrespeitados pelos políticos, profissionais de saúde e de assistência social das comunidades atingidas. A falta de informações e de uma materialização da perda causou desconforto, angústia e tristeza, dando margem a reações como a esperança de um reencontro com o familiar desaparecido. No entanto, essa esperança é geradora de ansiedade no cotidiano dos enlutados, pois estes sentem-se sozinhos em seu sofrimento, o qual muitos familiares e amigos não conseguem compreender.

Além da triste constatação da quantidade de pessoas atingidas, devemos nos atentar para o duro processo de elaboração individual, familiar e coletivo de luto que não se deixa fluir, ficando em muitos casos contido e mal resolvido; um porto de angústias diante de uma imensidão de perdas diretas e indiretas, 
prováveis ou irrefutáveis. Perdas materiais e de objetos de valor sentimental completam o conjunto de lutos a serem elaborados e tornaram a experiência traumática em algo ainda mais intenso e penoso.

Diante da perda da casa, sentimentos de perda de identidade, medo, desamparo, insegurança, abatimento e desesperança diante de um futuro incerto foram evidentes, acentuados pelo desalojamento das famílias de suas casas parcial ou totalmente interditadas pela Defesa Civil. O momento de saída das moradias foi percebido como o abandono não só da estrutura física que compunha o local, mas também de parte importante da história individual e da família que ali residia. Cada parte da casa que ruiu continha signos e significados muito particulares para os membros do sistema familiar e estes são insubstituíveis na medida em que não podem ser resgatados. Mesmo nos casos dos sobreviventes que já residiam em outras casas na época da entrevista, o sentimento ainda é de não pertença, já que tudo só está sendo reconquistado porque tudo teve que ser perdido, e lembranças não se constroem como paredes, portas e janelas.

Além do desalojamento, há o fator das moradias provisórias. Para os sobreviventes que tiveram que ser removidos para estes espaços com suas famílias, sentimentos como falta de privacidade, desconforto e vergonha se fizeram presentes, acentuados pelo fato de não se sentirem no direito de reclamar ou questionar as condições a que tiveram que se submeter, já que estavam nestes locais “de favor". Estes espaços impediram também que muitas das reações de luto pudessem ser expressas, pois demandavam dos sujeitos que estes demonstrassem gratidão pela vida e pela moradia que lhes foi ofertada.

Há também que se levar em conta que a perdas de objetos de valor sentimental foi sentida com grande pesar pelos sobreviventes. Documentos e fotografias foram os objetos mais citados por nossos entrevistados e apontaram para o fato de termos nestes os registros de quem somos, quando e com quem nos relacionamos. As fotos, em especial, marcam os momentos importantes da vida em família e em sociedade, e a ausência destes registros foi sentida como perda de parte da própria história.

Vimos também que grande parte dos sobreviventes teve dificuldades para se lembrar dos eventos ocorridos nas semanas das chuvas, e seus relatos foram tomando forma conforme foram recebendo informações de pessoas da própria 
comunidade. Isso mostra que nosso discurso, sempre fruto da interação social, só pode ser construído na relação com os outros, e só passa a fazer sentido se este outro valida e também recebe de nós a validação da experiência vivida. É na memória coletiva que encontramos nossa memória individual e dela extraímos aprendizagens que nos possibilitarão rever nossos conceitos e adquirir novos recursos de enfrentamento para lidar com perdas futuras.

$\mathrm{Na}$ união do grupo, fortalecemos laços preexistentes e estabelecemos novos contatos, formando assim uma rede de apoio segura, fundamental para o processo de reconstrução individual e coletiva. Foi desta forma que os sobreviventes da Região Serrana reconquistaram, pouco a pouco, a confiança para seguir em frente e recomeçar suas vidas. A partir do todo, cada parte tem se tornado mais resiliente, dia após dia, de forma que todos fazem, a seu modo, parte dessa importante história de renascimento das comunidades atingidas.

Sugerimos, a partir de nossos achados, que pesquisas futuras investiguem mais aprofundadamente o papel da comunidade no processo de enfrentamento individual e coletivo em contextos de desastre, acreditando que este tipo de conhecimento possa ser parte de uma ação mais contundente junto às populações que residem em áreas comumente afetadas por eventos dessa magnitude. Não podemos compreender apenas o individuo isoladamente já que este é um ser social e as repercussões deste tipo de fenômeno transcendem as barreiras entre o público e o privado.

Também poderiam ser realizados estudos longitudinais de forma a investigar o surgimento (ou não) de transtornos mentais - como, por exemplo, o Transtorno de Estresse Pós-traumático - que precisa ser avaliado periodicamente em seus sinais e sintomas. Vimos que diversos autores apontam este transtorno como um dos quadros mais recorrentes em indivíduos expostos a situações traumáticas, e quanto mais nos dedicarmos a estes estudos, melhor poderemos prestar assistência a estes que são acometidos pela doença.

Em relação ao este modelo de pesquisa, sugerimos também estudos longitudinais que acompanhem a trajetória de reconstrução de comunidades desoladas por catástrofes e a recorrência de eventos dessa natureza sobre as mesmas cidades para avaliarmos o quanto tem sido efetivamente destinado a prevenção de novos desastres e preparação dos membros da comunidade para um 
plano de defesa e proteção de seus bairros. Implicar o sujeito em sua própria história pode ser a diferença que falta para diminuirmos o número de vítimas em uma nova ocorrência.

Devemos investir cada dia mais em pesquisas na área das Ciências Humanas em parceria com as demais áreas interessadas nos eventos calamitosos tais como a Geografia, Estatística e Sociologia - para, através do intercruzamento de saberes, buscarmos uma melhor compreensão acerca do fenômeno dos desastres. Não podemos negar os avanços da natureza sobre o homem e nem a urbanização desordenada e o mal uso dos recursos pelo homem sobre a natureza de forma a "psicologizarmos" todos os aspectos relacionados a este tipo de vivência; é preciso integrar os conhecimentos para aprimorarmos nossas atuações junto à população e construir com os outros profissionais um novo saber.

Trabalhar com pessoas enlutadas em contextos de desastre não é só lidar com perdas importantes, mas principalmente, lidar com impotência, insegurança, medo, dor e angústia acentuados frente à falta de ações e perspectivas de mudanças futuras. Trabalhar com famílias e comunidades devastadas por catástrofes é respeitar o luto individual, mas também coletivo; é permitir que seus sentimentos sejam expressos e validados, e que as ações solidárias também sejam reconhecidas em meio a tanto caos e destruição. Atuar em situações de emergência é mais que um trabalho: é a construção de um espaço de escuta, suporte e reconstrução junto aos sobreviventes. 


\section{REFERÊNCIAS BIBLIOGRÁFICAS}

AINSWORTH, M. Patterns of attachment: a psychological study of the strange situation. Hillsdale: Erlbaum, 1978. 391p.

BACHALARD, G. A poética do espaço. São Paulo: Martins Fontes, 2005. 248p.

BARDIN, L. Análise de Conteúdo. Lisboa, Portugal: Edições 70, 2009. 288p.

BAUMANN, Z. Medo líquido. Rio de Janeiro: Zahar, 2008. 240p.

BELlATO, R.; CARVALHO, E. C. O jogo existencial e a ritualização da morte. Rev. Latino-Am. Enfermagem, v. 13, n. 1, p.99-104, jan/fev. 2005.

BOSS, P. La perdida ambigua: cómo aprender a vivir con un duelo no terminado. Barcelona: Gedisa, 2009. 144p.

BOWLBY, J. As origens do apego. In: Uma base segura: aplicações clínicas da teoria do apego. Porto Alegre: Artes Médicas, 1989. p.33-47.

1998. 228p.

Formação e rompimento de laços afetivos. São Paulo: Martins Fontes, Apego: a natureza do vínculo. Volume I. São Paulo: Martins Fontes, 2002.

496p.

Perda: tristeza e depressão. Volume III. São Paulo: Martins Fontes, 2004.

423p.

BRASIL. Código de Processo Civil: artigos 1.159 a 1.169. Versa sobre a figura do desaparecido. Brasília, DF, 1973.

DF, 2002.

Novo Código Civil: artigos 22 a 39. Versa sobre a figura do ausente. Brasília,

Anuário Brasileiro de Desastres Naturais: ano 2011. Ministério da Integração Nacional/Secretaria Nacional de Defesa Civil/Centro Nacional de Gerenciamento de Riscos e Desastres. Brasília: CENAD, 2012. 80p. 
BROMBERG, M. H. P. F. A psicoterapia em situações de perdas e luto. Campinas: Psy II, 2000. $174 \mathrm{p}$.

CALDEIRA, T. P. R. Cidade de Muros: crime, segregação e cidadania em São Paulo. São Paulo: Edusp/Editora, 2000. 34p.

CARTER, B.; MCGOLDRICK, M. As mudanças no ciclo de vida familiar: uma estrutura para a terapia familiar. In: CARTER, B.; MCGOLDRICK, M. (cols.). As mudanças no ciclo de vida familiar: uma estrutura para a terapia familiar. 2ed. Porto Alegre: Artes Médicas, 1995. p.7-29.

CASTRO, A. L. C. Manual de desastres: desastres naturais. Brasília, DF: Ministério da Integração Nacional, 2003. 174p. Disponível em: http://www.esdec.defesacivil.rj.gov.br/documentos/publicacoes da secretaria nacional/6 desastres naturais volI.pdf. Acesso em: 23 nov. 2012.

CASEllato, G (org). Dor silenciosa ou dor silenciada? Perdas e lutos não reconhecidos por enlutados e sociedade. São Paulo: Livro Pleno, 2005. 158p.

JORGE, R. C. O objeto e a especificidade da terapia ocupacional. Belo Horizonte: Gesto. 1990. 95 p.

DOKA, K. J. Living with grief after sudden loss. In: DOKA, K.J.; DAVIDSON, J.D. (eds.). Living with grief: who we are, how we grieve. Hospice Foundation of America: Taylor \& Francis, 1996. 324p.

DUPUY, P.M.. General Stocktaking of the Connections between the Multilateral Dimension of Obligations and Codification of the Law of Responsibility. European Journal of International Law, v.13, n.5. Londres: Oxford University Press, p.10531081, 2002.

FOLHA.COM. Defesa Civil do Rio ignorou os alertas de chuva forte. 13 jan. 2011. Disponível em: http://www1.folha.uol.com.br/cotidiano/859823-defesa-civil-do-rioignorou-os-alertas-de-chuva-forte.shtml. Acesso em 12/04/2011.

FRANCO, M. H. P. (ed). Estudos avançados sobre o luto. São Paulo: Livro Pleno, 2002. 172p.

Atendimento Psicológico para emergências em aviação: a teoria revista na prática. Estudos de Psicologia. Natal-RN, v.10, n.2, p.177-180, 2005.

FREIRE, P. Pedagogia do Oprimido. Rio de Janeiro: Paz e Terra, 1987. 213 p. 
FREUD, S. Luto e Melancolia. In: Edição Standard Brasileira das Obras Psicológicas

Completas de Sigmund Freud. Rio de Janeiro: Imago, v. XIV, 1917. p.269-291.

FUKUMITSU, K. O. Uma visão fenomenológica do luto: um estudo sobre as perdas no desenvolvimento humano. Campinas: Livro Pleno, 2004. 87 p.

GLADWIN, C. H. et al. Modeling hurricane evacuation decisions with Ethnographic Methods. International Journal of Mass Emergencies and Disasters. Tampa/Flórida, v.19, n.2, p.117-143, aug. 2001.

GOLDEN, T.R. Gender differences. In: Swallowed by a snake: the gift of the masculine side of healing. Kengsinton: Golden Healing Publishing, p.73-96, 1996.

GOMES, R., MENDONÇA, E. A. A representação e a experiência da doença: princípios para a pesquisa qualitativa em saúde. In: MINAYO, M. C. S.; DESLANDES, S. F. (orgs). Caminhos do pensamento: epistemologia e método. Rio de Janeiro: Fiocruz, 2002. p.109-132.

GOVERNO DO ESTADO DO RIO DE JANEIRO. Administração de Abrigos Temporários $\left(1^{\text {a }}\right.$ ed). Secretaria de Estado da Defesa Civil do Rio de Janeiro. Rio de Janeiro: SEDEC, 2006. 244p.

GRÉGIO, C. Antes e depois do trauma: vivência traumática e o mundo presumido. São Paulo, 2005, 266p. Dissertação (Mestrado em Psicologia). Faculdade de Psicologia, Pontifícia Universidade Católica de São Paulo.

HALBWACHS, M. A memória coletiva (tradução: Beatriz Sidou). São Paulo: Vértice, 1990. 189p.

HOUAISS, A.; VILLAR, M. S. Significado da palavra presunção - página 2294. Dicionário Houaiss da Língua Portuguesa. Rio de Janeiro: Objetiva, 2001. 2.925p.

HODGKINSON, P.; STEWART, M. Coping with Catastrophe: a handbook of postdisaster psychosocial aftercare. Londres: Routledge, 1998. 271p.

HOBFOLL, S. E. Stress, culture, and community: the psychology and philosophy of stress. NY: Plenum Press, 1998. 296p.

JAMES, R. K.; GILLILAND, B. E. Crisis intervention strategies. Londres: Brookes Cole, 2001. 752p. 
JANOFF-BULMAN, R. Shattered assumptions: towards a new psychology of trauma. NY: Free Press, 1992. 256p.

JORNAL DO BRASIL. Após um mês, 10 mil continuam desabrigados na Região Serrana. 12 fev. 2011. Disponível em: http://www.jb.com.br/tragedia-naserra/noticias/2011/02/12/apos-um-mes-10-mil-continuam-desabrigados-na-regiaoserranal. Acesso em: 20 nov. 2011.

KRISTENSEN, P.; FRANCO, M. H. P. Bereavement and disasters: research and clinical intervention. In: NEYMEYER, R. A. et al. (eds.). Grief and bereavement in a contemporary society: bridging research and practice. NY: Routledge, 2011. p.189-202.

KLINGMAN, A.; COHEN, E. School-based multysistemic interventions for mass trauma. Hingham/MA: Kluwer, 2004. 233p.

KOURY, M. G. P. Ser discreto: um estudo do Brasil urbano sob a ótica do luto. João Pessoa. 2001. 301 p. Relatório Final da Pesquisa Luto e Sociedade. Grupo de Pesquisa em Antropologia e Sociologia das Emoções, Departamento de Ciências Sociais - UFPB.

Vozes, 2003. 215p.

Sociologia da Emoção: o Brasil urbano sob a ótica do luto. Petrópolis:

KOVÁCS, M. J. Morte e desenvolvimento humano. São Paulo: Casa do Psicólogo, 1992. $243 \mathrm{p}$.

KRUM, F. M. B. O impacto e as estratégias de coping de indivíduos em comunidades afetadas por desastres naturais. Rio Grande do Sul, 2007. 134p. Dissertação (Mestrado em Psicologia) - Programa em Pós-graduação em Psicologia do Desenvolvimento, Universidade Federal do Rio Grande do Sul.

LANDAU, J.; SAUL, J. Facilitando a Resiliência da Família e da Comunidade em Resposta a Grandes Desastres. Pensando Famílias, n.4, ano 4, p.56-78, 2002.

LUFT, L. O Lado Fatal. $4^{a}$ ed. São Paulo: Siciliano, 1989. 119p.

Perdas e ganhos. São Paulo: Record, 2003. 128p.

MARANDOLA JR., E.; HOGAN, D.E. Vulnerabilidades e riscos: entre geografia e democracia. Revista Brasileira de Estudos da População, n.22, v.1, 2005, p.29-53. 
MATOS, O. O mal-estar na contemporaneidade: performance e tempo. ComCiência Revista Eletrônica de Jornalismo Científico, n. 101, 10 set. 2008. Disponível em: http://www.comciencia.br/comciencia/handler.php?section=8\&edicao=38\&id=459. Acesso em: 09 jul. 2013.

MARCHEZINI, V. Desafios de gestão de abrigos temporários: uma análise sociológica de inseguranças e riscos no cotidiano de famílias abrigadas. São Carlos-SP, 2010. 218p. Dissertação (Mestrado em Sociologia) - Programa de Pós-Graduação em Sociologia, Universidade Federal de São Carlos.

Temporary shelters in disaster: strategies and symbolic meanings of displaced people to survive in quasi-public spaces in Brasil. In: Second International Conference of Young Urban Researches, Lisboa: Anais, 2011. p.1-14.

MIGUEL, S. P.; BUENO, M. H. Habilidades sociais e estratégias de enfrentamento: um estudo correlacional. 2007.2 Disponível em: http://www.psicologia.pt/artigos/textos/A0578.pdf. Acesso em: 29 nov. 2012.

MORALES-SOTO et al. Emergencias y desastres: desafios y oportunidades (de la casualidad a la causalidad). Revista Peruana de Medicina Experimental y Salud Pública, v. 25, n. 2, p. 237-242, 2008.

MORIN, E. O método 2: A vida da vida. Lisboa: Publicações Europa-América, 1980. $527 \mathrm{p}$.

NASIO, J. D. O livro da dor e do amor. Rio de Janeiro: Zahar, 1997. 220 p.

NORRIS, F. H. et al. 60.000 disaster victims speak: part I - an empirical review of the empirical literature 1981-2001. Psychiatry, v. 65, p. 207-239, 2002.

OCAMPO, H. T. Sistemas de atenção às vítimas de situações de emergências e desastres: contribuições possíveis da Psicologia. Brasília/DF, 08 jun. 2006. In: $1^{\circ}$ Seminário Nacional de Psicologia das Emergências e dos Desastres: contribuições para a construção de comunidades mais seguras (Conferência de Abertura). FINATEC/UnB.

OLIVEIRA, D. D. Desaparecidos civis: conflitos familiares, institucionais e de segurança pública. Brasília/DF, 2007, 317p. Tese (Doutorado em Sociologia), Instituto de Ciências Sociais, Departamento de Sociologia, Universidade Federal de Brasília.

OLIVEIRA, S. R. Onde está você agora além de aqui, dentro de mim? O luto das mães de crianças desaparecidas. Rio de Janeiro, 2008, 150p. Dissertação (Mestrado em Psicologia). Departamento de Psicologia, Pontifícia Universidade Católica do Rio de Janeiro. 
ORGANIZAÇÃO MUNDIAL DE SAÚDE (OMS). Organização Pan-Americana de Saúde. $2009 . \quad$ Disponível em: http://www.opas.org.br/ambiente/temas.cfm?id=47\&area=Conceito. Acesso em: 12 abr. 2011.

ORLANDI, E. P. Análise de discurso: princípios e procedimentos. 7ed. Campinas: Pontes, 2007. 100p.

ORGANIZAÇÃO DAS NAÇÕES UNIDAS (ONU). Furacão Sandy deixa 68 mortos no Caribe, relata Organização Mundial da Saúde. 2012a. Disponível em: http://www.onu.org.br/furacao-sandy-deixa-68-mortos-no-caribe-relata-organizacaomundial-da-saude/. Acesso em: 07 mai.2013.

Relatório Anual de Desastres. 2012b. Disponível em: http://www.unisdr.org/files/24692 2011disasterstats.pdf. Acesso em: 18 set. 2012.

PARKES, C. M. Luto: estudos sobre a perda na vida adulta. São Paulo: Summus Editorial, 1998. 290 p.

Amor e perda: as raízes do luto e suas complicações. São Paulo: Summus Editorial, 2009. 446 p.

PASSOS, S. F. S. Resiliência, regulação e grupo: primeiros socorros para equipes de emergência. In: ROSSI, C. P; NETTO, L. (orgs.). Práticas psicoterápicas e resiliência: diálogos com a experiência somática. São Paulo: Scortecci, 2013. p.29-49.

PESSOA, M. B. A morte de imortais: espetáculo de mitificação e consumo - um estudo das representações da morte na mídia contemporânea para uma contribuição do estudo do imaginário social brasileiro. Rio de Janeiro, 1996, 184p. Dissertação (Mestrado em Psicologia) - Departamento de Psicologia, Pontifícia Universidade Católica do Rio de Janeiro.

PORTAL G1. Região Serrana do RJ ainda tem 345 desaparecidos após chuvas, diz MP. 23 mar. 2011. Disponível em: http://g1.globo.com/rio-de-janeiro/chuvas-norj/noticia/2011/03/regiao-serrana-do-rj-ainda-tem-345-desaparecidos-apos-chuvas-dizmp.html. Acesso em: 12 abr. 2011.

RENEDO, M. G.; BELTRAN, J. M. G; VALERO,M. V. Psicología y desastres: aspectos psicosociales. Castelló de La Plana: Publicacions de la Universitat Jaume I, 2007. 272p.

RIPLEY, A. Impensável: como e porque as pessoas sobrevivem a desastres. Rio de Janeiro: Globo, 2008. 345p. 
SAPORETTI, L. A. Espiritualidade em Cuidados Paliativos. In F. S. Santos (ed.). Cuidados Paliativos: Discutindo a vida, a morte e o morrer. São Paulo: Atheneu, 2009. p. 268-281.

SARAIVA, K. M. P. O segredo converte-se num bebê: a importância do encontro da mãe com o bebê natimorto. Rio de Janeiro, 1999, 111p. Dissertação (Mestrado em Psicologia) - Faculdade de Psicologia, Pontifícia Universidade Católica do Rio de Janeiro.

SEDREZ, L. Cidade alagada: chuvas de verão, classe e estado no Rio de Janeiro 19661967. 2008. Disponível em: http://www.uel.br/prograd/maquinacoes/art_5.html. Acesso em: 04 mar. 2012.

SELIGMANN-SILVA, M. Reflexões sobre a memória, a história e o esquecimento. In: História, memória, Literatura: o testemunho na era das catástrofes. Campinas: UNICAMP, 2003. p.59-87. Narrar o trauma: a questão dos testemunhos de catástrofes históricas. Psicologia Clínica, Rio de Janeiro, v.20, n.1, p.65-82. 2008.

SCHMIDT, M. L. S; MAHFOUD, M. Halbwachs: memória coletiva e experiência. Psicologia USP. Instituto de Psicologia da Universidade de São Paulo, São Paulo, v.4, n.1, p.285-298. 1993.

SIENA, M: VALENCIO, N. F. L. S. Danos imateriais relacionados às chuvas: culpabilizando a vítima. Revista EcoTerra Brasil: temas ambientais. Disponível em: 〈http://www.ecoterrabrasil.com.br $>$. Acesso em: 2 jun. 2005.

SOUZA, M. T. S. Resiliência e desastres naturais. Ciência e Cultura, n.63, v.3, p.4-5, 2011.

SPIGNESI, S. As 100 maiores catástrofes da história. Rio de Janeiro: Difel, 2005. 496 p.

STROEBE, W.; STROEBE, M. Bereavement and health: the psychological and physical consequences of partner loss. Cambridge: Cambrigde University, 1987. 304p.

STROEBE, M, S.; SCHUT, H. Models of coping with bereavement: a review. In: STROEBE, M.S.; STROEBE, W.; HANSSON, R.O (eds.). Handbook of bereavement. Cambridge: Cambridge University Press, 2001. p.375-404. 
TORLAI, V. C. A vivência do luto em situações de desastres naturais. Dissertação (Mestrado em Psicologia). São Paulo, 2010, 136p. Faculdade de Psicologia, Pontifícia Universidade Católica de São Paulo, São Paulo.

UOL. Sobe para 242 o número de mortos no incêndio na boate Kiss. 19 mai. 2013. Disponível em: http://noticias.uol.com.br/cotidiano/ultimas-noticias/2013/05/19/sobe-para-242-onumero-de-mortos-no-incendio-na-boate-kiss.htm. Acessoem: 30jun. 2013.

UNIVERSIDADE FEDERAL DE SANTA CATARINA. Atlas Brasileiro de desastres naturais: 1991 a 2010 - volume Rio de Janeiro. Centro Universitário de Estudos e Pesquisas sobre Desastres. Florianópolis: CEPED-UFSC, 2012. 63p.

VALENCIO, N. F. L. S. Dimensões psicossociais e político-institucionais do desastre de Camará (PB): limitações da resposta da Defesa Civil frente ao rompimento de barragens. Rio de Janeiro, 2005. 20p. Anais do Encontro Ciências Sociais e Barragens. Universidade Federal do Rio de Janeiro.

Sociedade, n.7, p.163-183, out. 2005.

Chuvas no Brasil: representações e práticas sociais. Revista Política e

Os desaparecidos nos desastres. 2011. Disponível em: http://www.ufscar.br/neped/pdfs/artigos_de_opiniao/Artigo_de_opiniao__Norma_Valencio_-_2011-3.pdf. Acesso em: 14 jun. 2013.

VALENCIO, N.F.L.S., etal.A produção social do desastre: dimensões territoriais e políticoinstitucionais da vulnerabilidade nas cidades brasileiras. Revista Teoria \& Pesquisa. São Carlos-SP, v.44-45, p.67-115, jul./dez. 2004.

VALENCIO, N. F. L. S; MARCHEZINI, V., SIENA, M. Desastre e indiferença social: o Estado perante os desabrigados. Antropolítica, Rio de Janeiro: Universidade Federal Fluminense, v.23, p.223-254. 2009.

WALSH, F. Family resilience: a framework for clinical practice. Family Process, v.42, n.1, p.1-18, 2003.

WALSH, F; McGOLDRICK, M. (orgs.). A perda e a família: uma perspectiva sistêmica. In: Morte na família: sobrevivendo a perdas. Porto Alegre: ArtMed, 1998, p.27-55.

WORDEN, J. W. Terapia do luto: um manual para o profissional de saúde mental. Porto Alegre: Artes Médicas,1998. 248p. 


\section{ROTEIRO PRELIMINAR DE ENTREVISTA}

\section{Tópicos para a entrevista}

- Perdas vividas em decorrência das chuvas de janeiro/2011 - humanas, saúde/integridade física (doenças/sequelas), materiais (casa, roupas, dinheiro), sociais (como instituições [escolas, igrejas, local de trabalho], pertences de valor afetivo (fotos, documentos, objetos pessoais)

- Perda humana por desaparecimento: quem é o desaparecido, onde este estava na ocasião das chuvas, como soube que a pessoa estava desaparecida, realização de buscas (por conta própria/amigos/autoridades), hipóteses sobre o que aconteceu.

- Rituais

- Rede de apoio - relação entre os sobreviventes

- Exposição ao evento traumático (estava na cidade/casa quando as chuvas ocorreram, sofreu alguma lesão/intercorrência em decorrência do desastre, participou de atividades de resgate/auxilio aos demais atingidos)

- Abrigo temporário 


\section{FICHA DE IDENTIFICACÃO DOS PARTICIPANTES E TERMO DE CONSENTIMENTO LIVRE E ESCLARECIDO}

\section{Dados de identificação:}

Nome:

Data de Nascimento:

Estado Civil:

Filhos ( ) Sim ( ) Não Quantos:

Profissão: Ocupação atual:

Endereço:

Bairro:

Cidade/Estado:

Telefone:

Familiar desaparecido (grau de parentesco):

Idade do desaparecido:

Título da pesquisa: "É possível dizer adeus? Repercussões de múltiplas perdas e o desaparecimento de pessoas em contextos de desastre".

Pesquisadora: Sandra Rodrigues de Oliveira.

Orientadora: Prof ${ }^{\mathrm{a}}$. Terezinha Féres-Carneiro

Instituição: Pontifícia Universidade Católica do Rio de Janeiro (PUC-RIO)

Você está sendo convidado(a) a participar de uma pesquisa de Doutorado que tem como objetivo investigar as repercussões do desaparecimento de um familiar durante as chuvas ocorridas em janeiro de 2011 em diversas cidades da Região Serrana do Rio de Janeiro, bem como compreender a vivência de ser sobrevivente deste mesmo evento. 
Para a realização deste estudo, os dados serão coletados através de entrevistas, uma com cada participante. Para registro dos dados, será utilizado um aparelho de gravação de voz, que visa, apenas, facilitar a sistematização posterior das informações coletadas. Não há nenhum risco em sua participação nessa pesquisa.

Caso concorde em participar, todos os dados que possam levar à sua identificação serão omitidos, preservando sua privacidade e garantindo o sigilo das informações. Se você preferir não participar, isto não afetará em absoluto sua relação com a instituição parceira. Você também pode desistir de participar da pesquisa depois de começar a responder as perguntas.

Se você concorda em participar do estudo, assine seu nome neste termo de consentimento cuja cópia lhe será fornecida.

Declaro que, após estar totalmente esclarecido(a) pela pesquisadora e ter entendido o que me foi explicado, aceito participar da presente pesquisa.

$$
\text { Rio de Janeiro, de de 201_. }
$$




\section{Anexo III. Tabela de participantes}

\begin{tabular}{|c|c|c|c|c|c|c|c|}
\hline NOME & IDADE & ESCOLARIDADE & PROFISSÃO & $\begin{array}{l}\text { ESTADO } \\
\text { CIVIL }\end{array}$ & FILHO & $\begin{array}{c}\text { FAMILIAR } \\
\text { DESAPARECIDO }\end{array}$ & $\begin{array}{c}\text { PERDAS } \\
\text { CONCOMITANTES }\end{array}$ \\
\hline Mônica & 42 & Médio completo & Embaladora & Casada & 4 & Irmão & Casa (perda total) \\
\hline Ariane & 37 & Médio completo & $\begin{array}{l}\text { Auxiliar Pet } \\
\text { Shop }\end{array}$ & Amasiada & 2 & Pai & Emprego/igreja \\
\hline Luzia & 32 & $\begin{array}{l}\text { Fundamental } \\
\text { completo }\end{array}$ & $\begin{array}{c}\text { Empregada } \\
\text { doméstica }\end{array}$ & Casada & 2 & Prima & Casa (perda total) \\
\hline Bárbara & 25 & Médio completo & Escrivã & Casada & 1 & Pai & 2 irmãs/casa dos pais \\
\hline Suely & 39 & $\begin{array}{c}\text { Fundamental } \\
\text { incompleto }\end{array}$ & Diarista & Divorciada & 3 & Sobrinho & Casa (perda total) \\
\hline Nadir & 50 & $\begin{array}{c}\text { Fundamental } \\
\text { incompleto }\end{array}$ & Diarista & Casada & 7 & Filho (17 anos) & Casa (interditada) \\
\hline \begin{tabular}{|l|} 
Zenaide \\
\end{tabular} & 44 & Médio completo & Vendedora & Casada & 2 & Tia & Emprego \\
\hline Hortência & 37 & $\begin{array}{c}\text { Fundamental } \\
\text { completo }\end{array}$ & $\begin{array}{c}\text { Empregada } \\
\text { doméstica }\end{array}$ & Amasiada & 1 & Avó/mãe & Tias/Casa (interditada) \\
\hline Olímpia & 43 & Médio completo & Estoquista & Casada & 4 & Sogra & Emprego/escola filhos \\
\hline Verônica & 28 & Médio incompleto & Caixa & Casada & 2 & Irmã/irmão & Emprego \\
\hline Tereza & 42 & $\begin{array}{c}\begin{array}{c}\text { Fundamental } \\
\text { completo }\end{array} \\
\end{array}$ & $\begin{array}{c}\text { Empregada } \\
\text { doméstica }\end{array}$ & Divorciada & 3 & Irmão & Casa (perda total) \\
\hline Flávia & 33 & $\begin{array}{c}\text { Fundamental } \\
\text { completo }\end{array}$ & Vendedora & Casada & 1 & Tia & Sobrinha/Emprego \\
\hline Gerson & 49 & Médio completo & $\begin{array}{c}\text { Manutenção } \\
\text { de esteira }\end{array}$ & Casado & 3 & Irmão & Cunhada/2 sobrinhos \\
\hline Bruno & 25 & Médio incompleto & $\begin{array}{c}\text { Entregador de } \\
\text { pizza }\end{array}$ & Casado & 1 & Irmã & Casa (interditada) \\
\hline Cândido & 53 & Médio incompleto & Jornaleiro & Casado & 2 & Irmão & Casa (perda total) \\
\hline Fernando & 26 & Médio completo & $\begin{array}{c}\text { Montador de } \\
\text { motor }\end{array}$ & Casado & 2 & Mãe & Padrasto/igreja \\
\hline Sérgio & 49 & Médio incompleto & $\begin{array}{l}\text { Bombeiro } \\
\text { hidráulico }\end{array}$ & Casado & 5 & Filho (12 anos) & Casa (perda total) \\
\hline
\end{tabular}




\begin{tabular}{|c|c|c|c|c|c|c|c|}
\hline Ronaldo & 35 & Médio completo & $\begin{array}{c}\text { Montador de } \\
\text { motor }\end{array}$ & Casado & 1 & Pai/mãe & 2 irmãos \\
\hline Emerson & 37 & Médio completo & Gari & Divorciado & 3 & Irmã & Casa (perda total) \\
\hline Osmar & 51 & $\begin{array}{c}\text { Fundamental } \\
\text { incompleto }\end{array}$ & Pedreiro & Casado & 4 & Irmão & Casa (perda total) \\
\hline
\end{tabular}

